
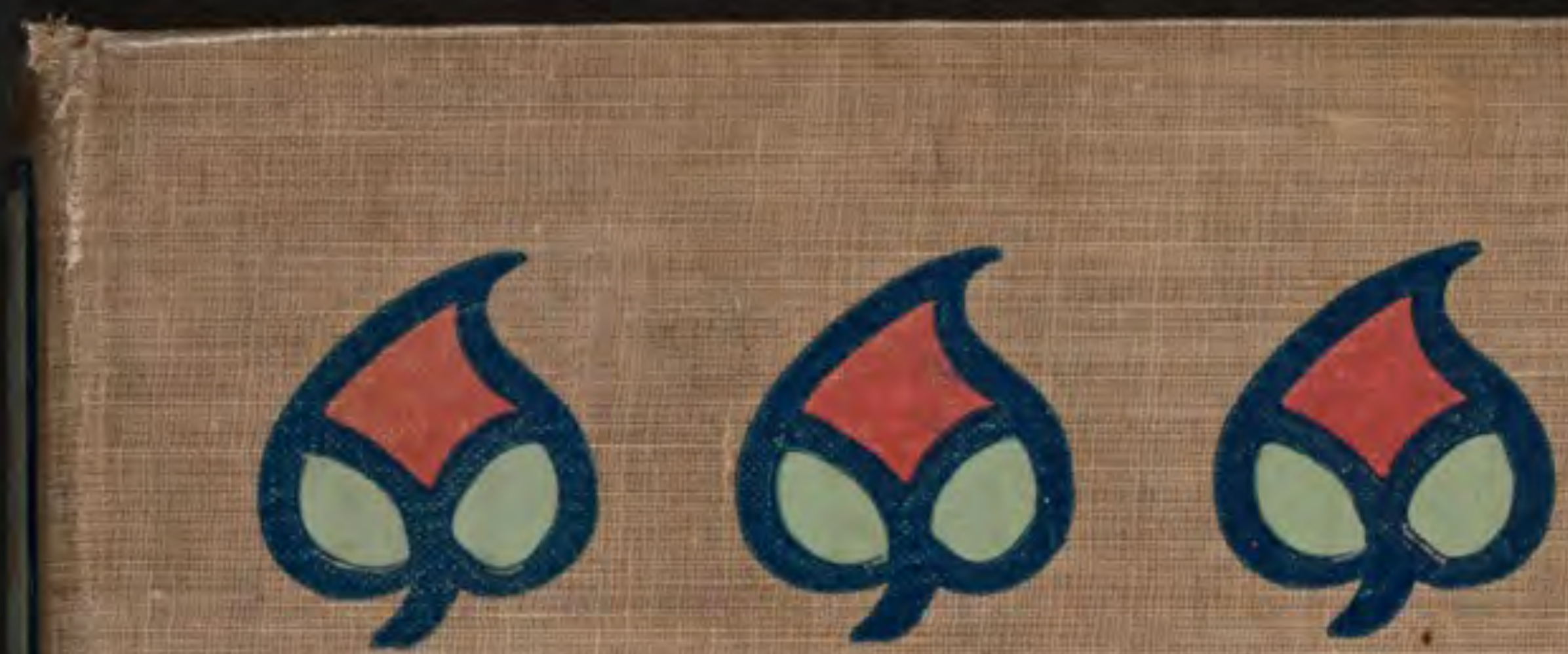

\title{
THE LIFE OF
}

ABDUR RAHMAN AMIR OF AFGHANISTAN
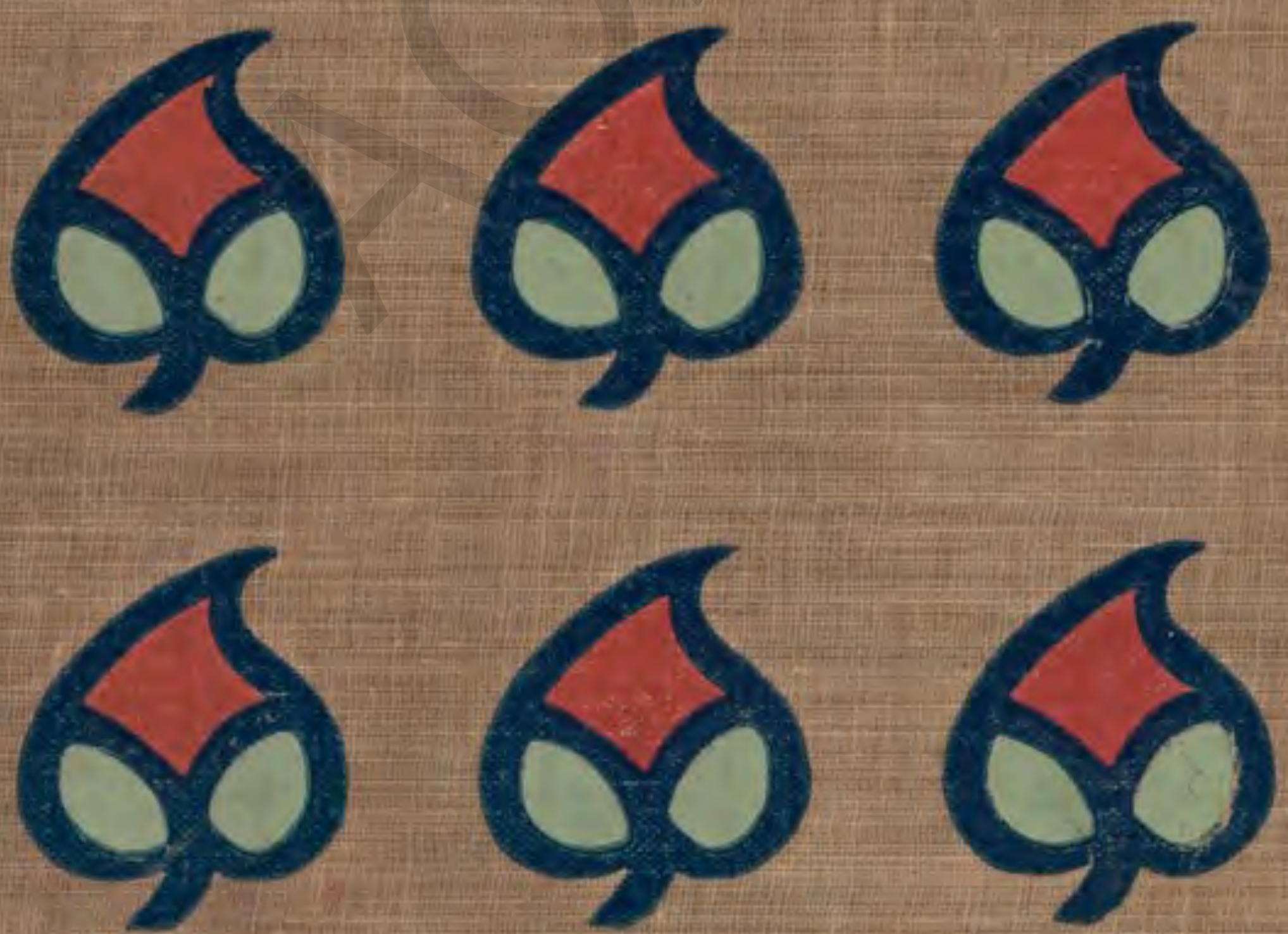









\title{
THE LIFE OF ABDUR RAHMAN
}

\author{
AMIR OF AFGHANISTAN
}






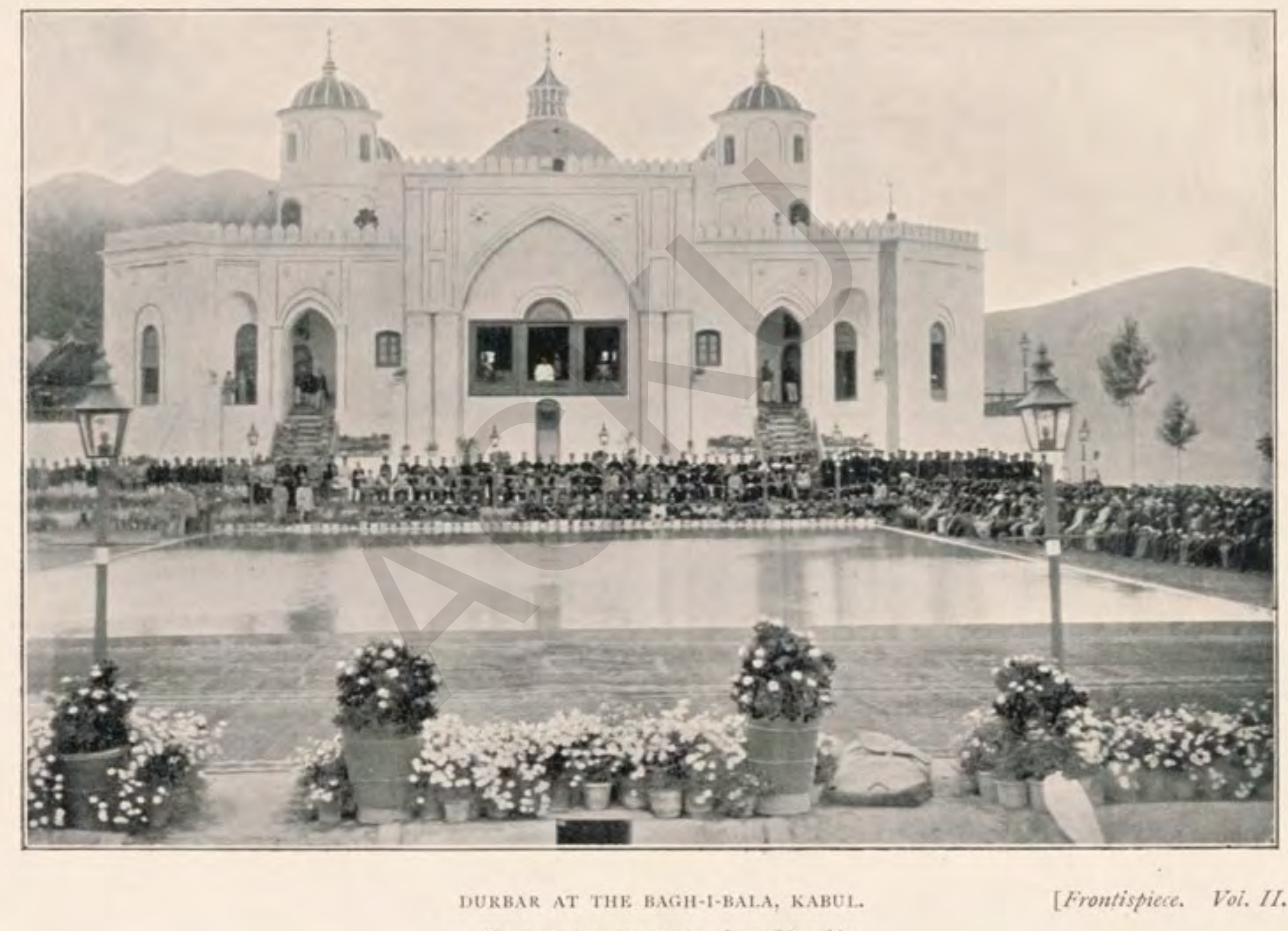

The Amir is in the suindono dressed in swhite. 


\title{
THE LIFE OF
}

\section{ABDUR RAHMAN ald al- Ralmant Rhan, AMIR OF AFGHANISTAN}

\author{
G.C.B., G.C.S.I.
}

EDITED BY MIR MUNSHI

SULTAN MAHOMED KHAN

ADVANCED STUDENT OF CHRIST'S COLLEGE, CAMBRIDGE

SECRETARY OF STATE OF AFGHANISTAN; BARRISTER-AT-LAW

WITH PORTRAIT, MAPB, AND ILLUSTRATIONS

IN TWO VOLUMES

VOL II

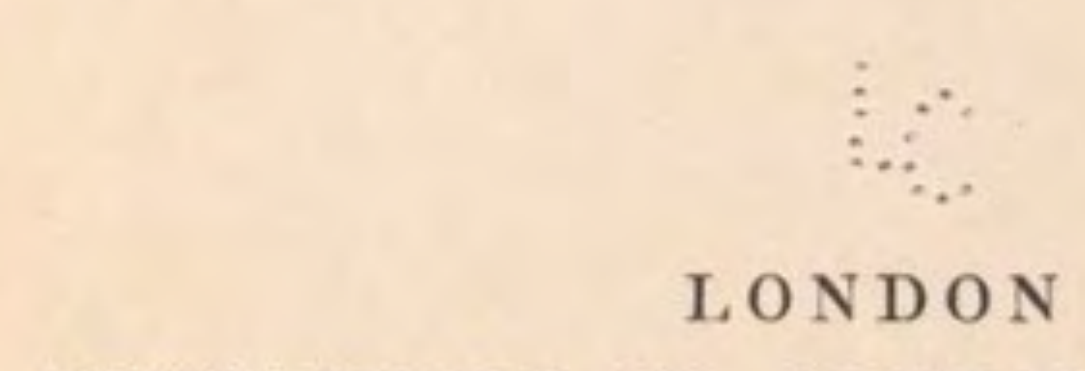

JOHN MURRAY, ALBEMARLE STREET

1900 
DS 366

. A13

copy 2

$0137 D I$

13 m 44 


\section{CONTENTS}

\section{CHAPTER I}

MY SUCCESSOR TO THE THRONE OF KABUL

CHAP'TER II

THE MEANS I TOOK FOR THE ENCOURAGEMENT OF PROGRESS IN COMMERCE, INDUSTRIES, AND ARTS

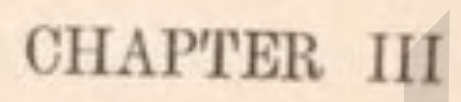

CHAP'TER III

GOVERNMENT DEPARTMENTS

CHAPTER IV

A FEW DETAILS IN MY DAILY LIFE

\section{CHAPTER V}

ANGLO-AFGHAN RELATIONS

\section{CHAPTER VI}

THE BOUNDARIES OF AFGHANISTAN AND THE DURAND MISSION

CHAPTER VII

THE FUTURE OF AFGHANISTAN

CHAPTER VIII

ENGLAND, RUSSIA, AND AFGHANISTAN . 


\section{LIST OF ILLUSTRATIONS}

DURBAR AT THE BAGH-I-BALA, KABUL

Frontispiece

OLD AFGHAN ARMS AND ARMOUR .

To face page 20

UNIFORM OF ROYAL INFANTRY . . . . $\quad, \quad$. 56

AFGHANS AT DINNER _ _ . . . . $\quad, \quad 94$

UNIFORM OF ROYAL CAVALRY . . . . $\quad$. $\quad 192$

GENERAL MAP OF AFGHANISTAN . . . At end 


\section{THE AMIR OF AFGHANISTAN}

\section{CHAPTER I}

MY SUCCESSOR TO THE THRONE OF KABUL

THERE is much criticism and difference of opinion as to who will be my successor to the throne of Kabul; many guesses are made, and people wonder why I do not openly and publicly declare my successor. On this question, however, not only are foreigners kept in the dark, but even my own countrymen and relatives have not been told my intentions. Some people conjecture that my eldest son, Habibullah Khan, whom they consider the rightful heir, will be the fortunate person; others mention Nasrullah Khan, my second son, because he was chosen by me to go to England upon a visit to Her Majesty, Queen Victoria; this, they say, is a clear sign that I shall appoint him to succeed me. Others, again, held the opinion, before the death of Hafizullah, my dearest and most beloved son, who was so handsome and such a favourite, that he was the heir in my mind. Others say, No, Mahomed Omar, whose mother is one of my most influential wives, will be the heir. I have reasons for not making any public declaration on this question to voL. II. 
ignorant uncivilised people, but for the information of those who are gifted with wisdom, diplomacy, and common-sense, I have given out very plainly and publicly who is to be my heir, by my actions and the practical work of administration of the public affairs of the kingdom. There are numerous reasons why I do not wish to make any public declaration. I will mention a few :

(1) It has frequently happened in the past that the life of the heir has been endangered; and, consequently, I prefer to conceal my intentions as long and as far as I can.

(2) The troubles that came to my predecessor, Shere Ali, who appointed Abdullah Jan as his successor, are quite sufficient to deter me from following his example; for his other sons rebelled against him.

(3) Of course the throne is the property of the Almighty King of kings, our Creator, who appoints kings as shepherds to guard His flock, and into whose care He confides the creatures of His hands. I therefore leave it unto Him to elect that one of my sons to be the future Amir who proves by his merits to be the most worthy of the honour.

(4) To those who are acquainted with the history and affairs of Afghanistan, it is well known that the kingdom is ruled on constitutional principles, namely, the people have full authority to choose their king; and kings, who have been forced upon the people against their wish, have lost not only the kingdom but their heads as well! It would, therefore, be ridiculous to force one of my sons upon them against their wish; it is better to leave it to the people to decide who shall be their ruler.

(5) Examples are not wanting in history where heirs, after being nominated as such by the reigning monarch, have tried to put an end to the lives of their own fathers to hasten on their own time for ruling. Though I am proud of the good disposi- 
tion of my sons, at the same time I know the bad disposition of the people of Afghanistan, who have so often stirred up brothers against brothers and sons against their fathers.

(6) I do not like to cause disputes, quarrels, and annoyances amongst my own family during my lifetime; if they will only be wise, and stick to one of my sons and be united and onehearted amongst themselves, there will be no fear of the public peace being disturbed. But if they do quarrel it will be just as well that they should be punished for their bad behaviour in not listening to my advice.

I need not give any more reasons for not publicly nominating my successor; I will only mention here that I have shown very plainly to the Afghan people, and others outside Afghanistan, which of my sons I consider to be the rightful heir to my throne. Before proceeding further, however, I must contradict the statements of those who, either from ignorance or selfish and mercenary motives, are trying to get money from my wives and sons by flattering them that they will be the heirs to my throne. I should think it unwise to give full details on this point, on which it is more politic to be as guarded as possible. But all these people who spread such rumours abroad are simply ignorant of my intentions in this respect.

The policy which I have adopted concerning my successor requires that some reference be made to the history of Afghanistan, and although this has been treated more in detail in another part of my book, I will give a few words here relating to such policy.

The first King of the Durani dynasty, to which I belong, was Ahmad Khan, better known as Ahmad Shah Durani, or Abdali, who succeeded to the throne of 
Afghanistan in A.D. 1748, corresponding to 1061 Hijira (the year of Mahomed's flight). He was a constitutional monarch, and was proclaimed king by the chiefs and representatives of various tribes who, being tired of the troubled state of the country, wanted to have one king at their head for the sake of peace. Ahmad Shah, acting on the advice of the representatives of these tribes, was a very popular ruler. He also conquered India and became one of the greatest Emperors in the East. After Ahmad Shah's death, history records in full detail how his sons, owing to discords between them and their endeavours to break down the constitutional system of Government, lost the kingdom. The last King, named Shah Shujah, whom the English wished to force upon the people against their wish, was killed by the Afghans together with many English also who supported him.

My grandfather, Dost Mahomed Khan, himself found that the principal cause whieh led to the ruin of Ahmad Shah's dynasty was that Timur, in his lifetime, divided his kingdom into provinces, appointing his sons to be Governors of the various provinces. Each son had his separate revenue as well as his own army, and after the death of their father, which happened in 1793, they fought amongst themselves, thereby greatly reducing the strength of the kingdom. I need not relate in detail here, how my grandfather, Dost Mahomed Khan, succeeded to the throne, owing to the quarrels between Timur's sons. He also made the same mistake by dividing the kingdom of Afghanistan among his sons, and giving to every one of them a separate army. In consequence of this policy the sons were placed by their 
own father in the position of being able to fight against each other. For instance, my father was the Viceroy of Turkestan, and had the largest and strongest army, second only in force to that of the King. My grandfather appointed Shere Ali Khan, his other son, to be the head of the army that was with him at Herat at the time of his death. My uncle Azim had the provinces of Kuram and Jaji with the forces there as his inheritance. Shere Ali's own brother, Amin, had Kandahar together with its soldiers. Sirdar Aslam Khan was placed over Hazara and Bamian, and so on, the rest of the provinces with their soldiers being divided among all the other sons. When my grandfather died, therefore, they were all prepared to fight against each other. This condition of things caused a great deal of weakness and bloodshed in the kingdom from the constant quarrels.

Having before my eyes these examples as an object lesson, I am not going to follow in the footsteps of my predecessors, thereby causing my own sons to fight between themselves. I therefore keep my sons in my capital of Kabul, and they are all under the orders of my eldest son; I have arranged matters in this way.

At the commencement I gave my eldest son very little work, but gradually added to his duties, and also to his dignity and authority, as he advanced in years and experience, placing many matters connected with the administration of my kingdom under his care. So far have I proceeded in this policy, indeed, that I do not myself now hold the public audience (or durbar), which all the Kings of Afghanistan, including myself, 
have always attended in person; I leave this duty entirely to my eldest son. I have appointed my second son, Nasrullah (Habibullah's own brother), head of the Accountant-General's and Revenue Offices, under his eldest brother's orders. He takes all instructions from and gives in all his reports to him. My other sons, Aminullah, Mahomed Omar, Ghulam Ali, etc., will be appointed in their turn to various official posts, also under the orders of Habibullah, their eldest brother. The heads of every department, whether civil or military, send in their despatches and reports of the work done to my eldest son; they also attend his durbar with the same ceremony and state that is observed at my own.

Upon all matters connected with instructions to the Governors of provinces, to Generals and other military officers, stationed at various points in my kingdom, my eldest son acts according to my instructions. These instructions are either in the form of a written code of law, in which case he is not obliged to ask me any questions; or he receives them directly from me in particular cases that arise during the course of the day, and consults me personally. But every official is instructed to look upon my son as the person whose commands must be obeyed. In addition to this, since the year 1897, I have given my son authority over the State Treasury and Exchequer, which until then had been entirely under my own control. All orders for Treasury payments are issued by my son. $\mathrm{He}$ also has authority to appoint or dismiss Government officers, whether civil or military; he may increase or decrease their salaries. This authority, be it under- 
stood, is not quite absolute; everything is subject to my approval; but he exercises his powers in such a way that the people are taught to look upon him as fully empowered by me to act.

$\mathrm{He}$ is also the Supreme Court of Appeal; he is above all the ecclesiastical courts, the revenue and commercial courts, and the criminal courts: there is no court over him, with the exception of my own durbar.

Various writers have made a grave mistake in stating that the succession to the Kabul throne depends on the rank of the mother of the claimant.

At one time they discussed the chances of Shere Ali's title to the throne of Kabul, on the ground that his mother was a lady of the royal family. Upon this account, said they, he was better entitled to the throne than my father, Amir Afzal. This is a mistake. In the first place, my mother was a lady of the old royal family, descended from Shah Tahmasp, while Shere Ali's mother belonged to a clan called Salimzai, a branch of Populzai, and none of her ancestors had sat upon any throne.

On the other hand, Amir Dost Mahomed's mother was a Kazil-bash, a family quite foreign to Afghanistan, but for all that he was made Amir.

In the first place, the Mahomedan religion, by the laws laid down by God's Holy Book, the Koran, and by Mahomedan traditions, looks upon all the children without any distinction between their mothers, as having equal rights of inheritance. So much so, that if the meanest and lowest born slave gives birth to a child, this child is entitled to claim equal rights with 
the children of the royal wife. Such a slave is considered as much a wife to her master as is any other married wife. There is no such thing, according to Mahomed's law, as superiority and inferiority or legal rights of one over the other. Therefore it is not right that one should be called the queen and the others nothing at all : if their husband is a king they are all queens, and if he is a beggar they are all beggars. Of course, there are favourites amongst them, but that does not mean that through their influence the king should ruin his reputation, as Amir Shere Ali did, by appointing as his heir his younger son, Abdullah Jan, a step that resulted in his other sons rebelling against him.

Leaving the religious side of the question, the Afghans are a brave nation of warriors, who do not select a king on account of his mother, but for his own merits and fitness for the post, as well as for the reason that he is the son of a king.

$\mathrm{Mr}$ (now Lord) Curzon was the first European who found out what my views on this subject were. In a humorous conversation in 1895 he began his remarks by a joke, and ended them with a most important political question as to who would be my successor. I, having already committed myself in a joke, could not refuse to give my views on the matter more fully than I originally intended. Luckily, however, the conversation took place in a small private room, where there were not more than two or three persons present to hear what I said, and therefore mischief could not be made by reports getting abroad. 
It is quite clear by our religion, as well as by our customs, that the eldest son succeeds to the throne, provided he is fitted for the post, and is also approved and selected by the nation. There have, however, been instances where younger sons have been nominated by fathers who were so weak as to allow themselves to be influenced by the mothers of such sons. The result has invariably been to plunge the country into civil wars, struggles, and failure. The wisest policy, in my opinion, is to act as I have myself done, and keep the royal family and princes under the influence and power of my eldest son. More than that, I have given him as much power and experience in the administration of the kingdom during my lifetime as the son of a king could ever expect under such cireumstances. He scarcely requires a fresh nomination to the throne after my death, for at that moment he would be prepared to fulfil all the duties he had been practising under my instructions and advice. $\mathrm{He}$ will not have to struggle and fight in order to establish his authority, nor are any of his brothers in a position to oppose him, they being his servants as are other officials in the kingdom. They are brothers by ties of blood, but servants in the administration of the kingdom.

My subjects ought to learn a lesson from Queen Victoria, who sent her son, the Duke of Connaught, to India, where he served most attentively and willingly under the English Generals who were servants of his mother, the Queen.

There are some outside enemies of my family to 
be considered, but I will only mention in a few words my views respecting my own sons. I will deal elsewhere with the people who lay claim to the Kabul throne. It is a curious thing that even well-informed and responsible Englishmen, holding high official positions, regard the Afghanistan of to-day in the light of twenty years ago. In illustration of this, it is just as if a person were to say: "Oh! the English Government is a very cruel Government, because it has such a cruel law as to hang a man for sheepstealing !" It is quite true that men were hanged for this fault at one time, but now that the people are more civilised and better educated, the laws are more lenient and more adapted to suit the needs of the nation. Just so with Afghanistan. The country has made more rapid progress during the last twenty years than many other countries in fifty years. People, therefore, who are ignorant of the great progress and changes that have been brought about, and the circumstances which led to those changes since my accession to the throne, should not assume a knowledge they do not possess. They will then avoid the mischief of misleading the British public by their writings.

Sometimes misleading articles appear in the English papers, giving the names of people as claimants to my throne, when such people either died years before the articles were written, or never existed at all. If they did exist, they never dreamt of such ridiculous nonsense. I hope that my people are wise enough and strong enough to choose for their king that one of my sons who is worthy of such a high responsibility, 
without the interference of any foreigners in their private home policy.

As the throne is practically in the hands of the representatives of the nation, I have tried to unite some of the most important families in the kingdom to my eldest son in the ties of blood-relationship, by marrying him to the daughters of some of the highest men in the land, and by engaging his sons to other daughters of a suitable age. Some of these marriages are as follows:

The first wife, and perhaps the most important, is the daughter of Mahomed Shah Khan, chief of the Taghab and niece of General Amir Mahomed Khan, the Senior General and head of the Kabul forces. This marriage unites my son to the most powerful Ghilzai Taghab tribe. The greatest danger as well as the greatest security of the ruler of Kabul depends upon the loyalty of the army, and the army of Kabul, I may say, is bound to obey its most popular officer, General Amir Mahomed Khan, in a case of emergency. My son's eldest son, named Inatullah, is the son of this first wife.

The second wife, and perhaps of equal importance with the first-named, if not even greater, is the daughter of Kazi Syadud-Din Khan, my officer at Herat; she is the grand-daughter of Abdur Rahman Khani Ulum (the head of the Church of Afghanistan). This wife also has a son. The uncles and cousins of this lady are the heads of the ecclesiastical courts at Kabul, Jellalabad, Kandahar, Herat, and Balkh, the largest towns in the kingdom.

The third wife, who has one son and one daughter, is the daughter of Shagasi Sarwar Khan, my former Gentleman Usher, holding the same post as that now filled by Sirdar Abdul Kudus Khan. $\mathrm{He}$ was afterwards appointed Viceroy and Governor-General of the whole of Turkestan, in the place of my cousin Ishak. He has been compelled to retire, unfortun- 
ately, on account of ill-health. Being a distinguished statesman, however, and still young and active, he will be of very great service to my son, if circumstances should require it. This lady is the step-daughter of Shagasi Sarwar Khan; her own father was the late Loi Naib, once in the service of Amir Shere Ali Khan. Her brothers are the only useful men that Ayub possesses.

The fourth prospective wife, to whom my son is betrothed but not yet married, is a most influential lady, even more so than the three already mentioned, so far as family is concerned. She is the grand-daughter of the late Amir Shere Ali Khan, and daughter of his eldest son, Ibrahim Khan, at present in India. This is a marriage which might unite the two royal families to the Kabul throne, namely, the late Shere Ali's family and mine. This union will put an end to the perpetual wars and troubles that were always taking place owing to the misunderstandings between my father and Amir Shere Ali and their descendants.

The fifth wife is also of a very noble family, and unites my son with Usbeg chiefs, as the daughter of Mir Sorabeg, exKing of Kolab and niece of Sirdar Kudus Khan on her mother's side.

The sixth wife is a daughter of the chief of the Mangal and Khost provinces. Her son, named Hayatullah, is second in age.

The seventh wife is the daughter of Akbar Khan, the Momand Khan of Lalpura. This alliance unites my son with the most powerful tribe of the Momands on the Indian frontier.

Habibullah's eldest son, Inatullah, is engaged to the daughter of Omra Khan of Bajaur; the other children are also engaged to members of noble families.

It is quite clear that if these important men are united to my family by such strong ties, it is to their own interest to support my son, who will thus 
be protected from internal as well as from external troubles.

My second son, Nasrullah Khan, is united to the following families. His first wife is a daughter of my only living uncle at Kabul, Sirdar Yussif Khan. The second wife is a daughter of the late Sirdar Fakir Mahomed Khan, whose brother Nur Mahomed Khan is the Colonel of my body-guard. The third wife is the daughter of my most trusted Commanderin-Chief at Herat, named Faramurz Khan.

In this manner, and in various other ways which do not concern this chapter, I have attempted to unite the representatives and chiefs of the various important positions and tribes to my son and family. 


\section{CHAPTER II}

THE MEANS I TOOK FOR THE ENCOURAGEMENT OF PROGRESS IN COMMERCE, INDUSTRIES, AND ARTS

\section{Foreigners in the Afghan Service.}

THE Creator of the world set an example to teach us that we are all dependent upon each other as followsthat in the person of every individual the members of the body depend on each other, e.g., the head without the body, or the body without the head, arms without hands and hands without fingers cannot be of any service at all. Therefore, the system of this world has been founded in such a manner that every human being stands in need of the help of some other person. The greatest sovereigns can learn a lesson from the thought that the mightiest among them is dependent for his comfort and needs upon menials, such as the cook, the shoeblack, the tailor, and so on. They must therefore not think that they can do everything themselves without help from others. They must also bear in mind that Almighty God took a week to make this world, as it is taught by the Bibles, to show us that patience is required for the completion of all projects and plans. We must not be too hasty, nor must we lose courage. 
The strength and force of every Government depends upon the elements of which it is composed. The more learned, experienced, clever, and useful men there are in the Government, the stronger, more progressive, and more flourishing that Government will be. It is for this reason that Governments employ, and appreciate, the services of able men.

Kings stand to their countries as the vice-regents of God. Either directly, or through their ministers, they exercise the rights of Fortune or Misfortune- of life and of death-over those who are placed under their rule. But they must always remember that the Almighty King of kings, whose viceroys they are, expects them to treat all His creatures with equal kindness and justice, without distinction of colour (be they black, fair, or red), no matter what their religion may be (whether Muslims, Christians, Jews, Hindus, Buddhists, even those who do not believe in the existence of God Himself). Arguing from this point, kings must act without partiality, and give equal rights and privileges to those who enter their service, or who take up their abode in his country, just as if they were his own subjects, irrespective of nationality or religion, to carry out the example of that Almighty King whose assistants they are in temporal affairs.

It is a curious thing that we are all very keen in discovering the faults of others and seeing our own virtues; but we are short-sighted in seeing our own faults and the virtues of others. A careful and attentive observer of modern life in various countries and kingdoms can easily judge for himself, whether it is the custom with all highly civilised and boastful 
powers to give the same rights, rank, and appointments to all their servants and subjects without distinction as to nationality, colour, creed, or religion. I am proud to say that people who have taken service in $\mathrm{my}$ kingdom have been raised to higher positions than even my nearest relatives. Such posts are those of Mir Munshi (Secretary of State), QuartermasterGeneral, Chancellor of the Exchequer, First Lord of the Revenue, personal doctors to myself and my family. This proves that I set more value upon merit and ability than upon the claims of relationship and personal friendship.

Insha'allah (God willing), if my sons and successors follow my example in employing able officials in their. service without prejudice against nationality or religion, their country will always prosper. They must persuade their own people and relatives to work by giving them every assistance in the shape of allowances, etc., and they must work for all they get. Sadi says in a popular poem:

"Without any pains there are never any gains,

That person only gains who takes pains."

Having now introduced the subject of this chapter, and having said a few words of advice to my sons and successors, I will proceed to state the steps I took to procure the services of clever and capable people from many different nations. I rewarded them for their services to me, and my nation benefited by their work and instruction, becoming skilful themselves in many crafts taught them by the foreigners. I continue to work upon the same principles, and I trust that my successors will do the same. 
It is impossible for me to give the names of all the men who have done me service, but I will mention a few of them who have not only executed work themselves, but have left something permanent behind them in the progress made, by which the Government has benefited. "Some have established entirely new departments in the country, others have taught the Afghans various trades and arts so well and thoroughly, that they are able to carry out the works entirely alone in the absence of their teachers.

Of the people from other countries who were and are employed by me, some have resigned and some have left my service on the expiration of their agreements, some are still working for me; others, again, have been dismissed, owing to their own fault. I will not mention the names of these people, as I do not wish to injure them in their future career wherever they may go. Of course if the world finds this out for itself I am not responsible. "Reveal not thou the errors of others, and so mayest thou expect the Almighty to overlook thine errors in return."-KoRAN.

My policy of introducing foreigners into the country is sometimes criticised. People wonder why I do not send my own people to Europe, instead of having teachers for them in Afghanistan. My reasons for this policy are as follows :

(1) To the question: Ought I to have sent my people to other countries to learn the different manufactures and industries? I will answer, in the first place, this would have entailed heavy expense, which expense the parents of the youths were neither willing nor able to pay, and my GovernvOL. II. 
ment was not rich enough to pay the money out of the Treasury.

(2) I have frequently asked my hakims (physicians) and workmen to bring their sons to me to be sent abroad and educated as doctors, engineers, and so on, but my request only met with the answer of silence !

(3) My subjects do not know foreign languages, and if they were to go abroad it would take a long time before they could do any practical work, as they would first have to learn the language so that they could understand the subjects written in it. I accordingly opened an office, under the superintendence of Mir Munshi Sultan Mahomed Khan, through whom also all the English and other foreigners employed in the various factories, ete., were instructed to send their reports to me. There the books on manufactures, mathematics, chemistry, physics, etc., are translated into Persian. A branch of this office is also to be opened in India. Several books have been already translated, and some are published as helps to the studies of the young men.

(4) It is my opinion that some of the Orientals who go to the West to be educated, instead of acquiring the abilities and merits of the Western peoples, import Western vices into their own country, such as drinking, gambling, etc. Many, too, lose all belief in faith and religion. I therefore consider it wiser to have the young people educated under my own supervision.

(5) No science has a solid foundation in a country unless it can be studied in the actual language of that country.

(6) In the present case, I keep on urging my people to learn their work properly and quickly, as well as insisting that the foreign instructors shall teach as quickly and thoroughly as possible, so that in case of their ever going away, they need not have any fear of me. In making agreements with Englishmen, Indians, and other foreigners, I insert a clause to the effect that they will not get leave to go to their own homes until the pupils are able to carry on their work without any supervision from their instructors. This clause has a wholesome effect on the 
foreign instructors, keeping them up to their work, so that on its completion they can go in peace to their own homes. I am glad to say that my country has greatly benefited by this scheme; various departments that were under the instructions of foreign teachers are now entirely worked and carried on by my own Afghan people.

\section{Manufactures and Industries}

I know that it is a very unwise policy to purchase an elephant without first preparing food and stabling for him. In the same way, it is not wise to buy machinery for making war materials and ammunition, and for articles of commerce, without first making arrangements for procuring the raw material to be worked up by the machinery, and so keeping it constantly at work. I wished to get out of the mines and from the natural products of my own country as much as possible. "Necessity is the mother of invention," and hunger does not give one patience to wait for luxurious food when ordinary food ean be had. I was in the most urgent need of the arms and ammunition for the wars which were taking place in my own country from time to time, and were expected to break out at any moment. I also wanted to buy machinery suitable for getting iron, coal, lead, copper, and other minerals out of the mines in Afghanistan. These, however, required a much larger sum than I could spare from the other necessities of my Government. I therefore first bought machinery for making guns, rifles, and cartridges, before establishing the more expensive machinery required for mining operations, and for providing 
the raw material for the daily consumption of the machines.

I am, however, gradually stopping the import of such raw materials from abroad, and bit by bit making use of the natural resources of Afghanistan, minerals as well as other products. These will be particularised in their proper place.

I have mentioned elsewhere the fact, that when I was a boy I hated reading and writing, and devoted myself to working with the other workmen in my father's workshops. The earnest desire of my life at that time was only to learn the profession of architecture, rifle-making, casting, carpentry, blacksmith's and other kinds of work. All these I mastered thoroughly, and could make the articles with my own hands, without the assistance of other workmen, quite as well as any of those who had taught me. Two rifles that I made entirely from start to finish without help from any one are now at Kabul.

In short, I was not fond of any other profession but that of engineering in the early years of my life. When I resided in Russian territory, I occupied my leisure time in learning all I could about manufactures and industries. I learnt at that time goldsmiths' work, enamelling, gilding, and dyeing leather, etc. I may mention that three of the foremen in my present workshops, named Ghulam, chief of the filing department; Zaman, rifle-maker; and Najaf, head of the blacksmiths' shop, were amongst those who taught me to do these works. I cannot give the names of all my teachers for want of space.

After my accession to the throne, being forced 


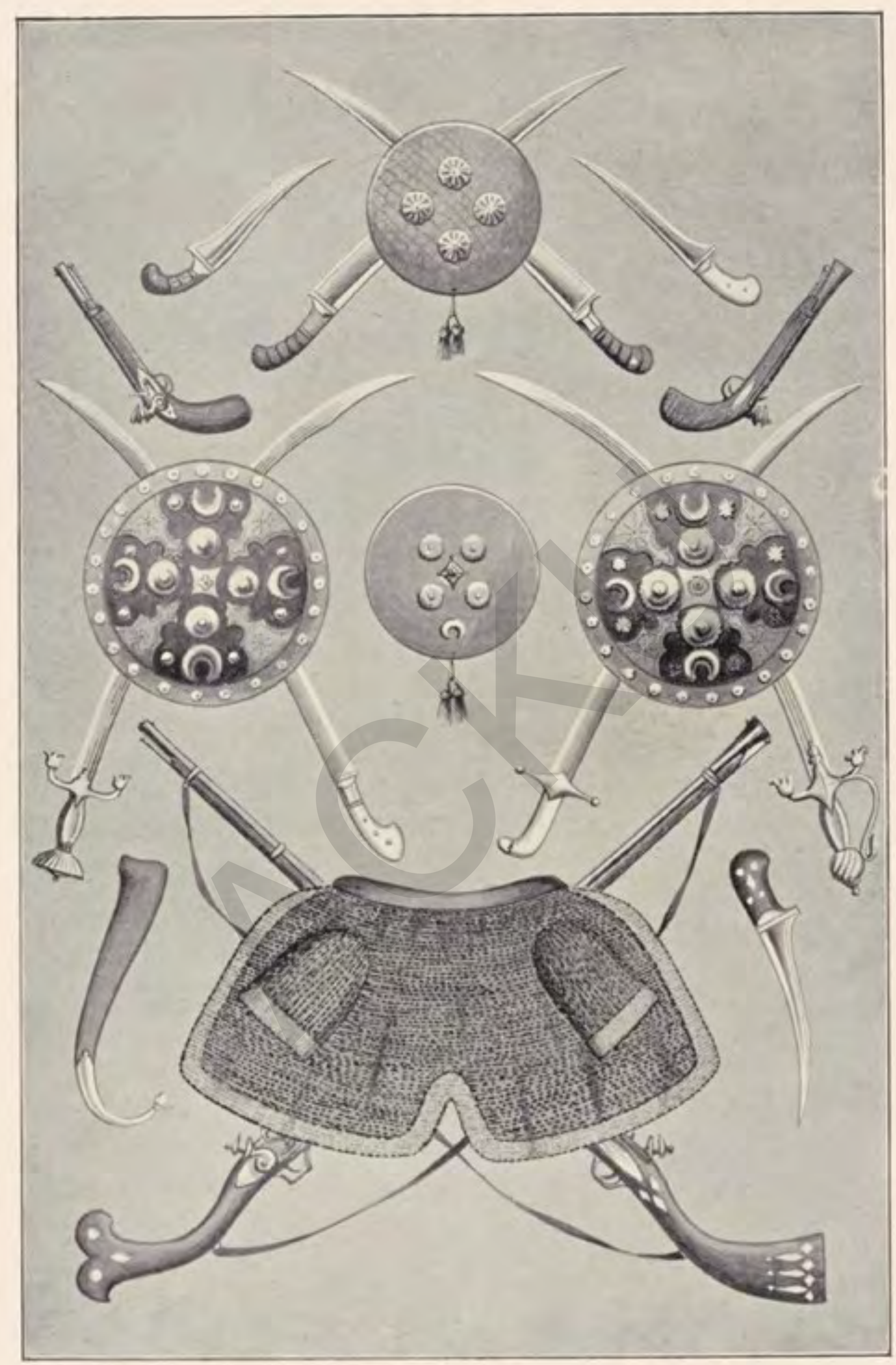

OLD AFGHAN ARMS AND ARMOUR. [To face p. 20. Vol. $I I$. 
partly by scarcity of arms, and partly because I was so fond of manufactures and industries, I started handfactories for making rifles and many other things. None of these works were carried on by steam power.

I was fully aware of the value and usefulness of steam power introduced by modern scientific men, and I knew that great and mighty empires, such as Great Britain, have attained their wonderful strength by the help of steam power and their world-wide commerce; otherwise, England is very small, and to my certain knowledge contains no diamond or gold mines. Their manufactures and commerce are the blessings and welfare of the nation and the strength of their kingdom.

But notwithstanding the fact that I appreciated the value of modern machinery, my external and internal troubles and anxieties did not allow of my giving sufficient attention to manufactures till 1885 , when I went to Rawal Pindi to meet my wise and learned friend, Lord Dufferin, then Viceroy of India.

At this time a French engineer, named M. Jérome, who was superintending the electric lighting machinery and engines, was introduced to me, as being a clever, well-informed man, and although he was only an electrical engineer, I found that he had a great deal of general experience about mechanical engineering. I therefore engaged him in my service, with the idea and intention of starting workshops at Kabul on the modern European system. My engineer brought with him another Indian who was clever at Electric Lighting works, named Karim Bakhsh, who is still at Kabul at the present time.

M. Jérome was the first European who entered my 
service in the capacity of engineer. He was at Kabul for a short time, and during his stay I looked at catalogues of various mechanical machinery, marking out a few lathes, drilling, shaping, punching, cutting, and cupping machines, together with a casting foundry, and three, six, eight, and ten horse-power engines. I also ordered a few other small machines to make a start. The whole of the machinery and engines required to start this small factory amounted to 141,000 rupees of the Indian coinage. I gave M. Jérome leave to go to India for the purpose of buying the machinery, and also to employ some other assistant engineers and Indian workmen well practised in work of the kind, to set the machinery in place, and put it into working order.

On M. Jérome's arrival at Calcutta, he engaged twenty-two Indian foremen, mistris, and other workmen, and sent them to Kabul along with the machinery. The workmen and machinery reached Kabul, but M. Jérome did not himself appear, and up to the present day I have not heard a word about him, neither have I been able to find out what happened to him nor why he did not return.

The machinery and goods were lying at Kabul, but there was no engineer. I was sorry, not only on account of the money which was lost in buying the machinery, but because I was the laughing-stock of my people, who thought I should be unable to start my small factory. "In Allah ma'al sabrin"="Allah is beside those who do not lose patience."-Koran.

I was not, however, a man accustomed to change my mind after once having fixed upon doing a thing. I 
accordingly wrote to my envoy with the Indian Government, General Amir Ahmed Khan, to find out and employ another engineer at any price. The General employed and sent, through Sultan Mahomed Khan, now Mir Munshi, an English engineer, named Mr Pyne (now Sir Salter Pyne). Mr Pyne arrived at Kabul in the first week of April, 1887, and I wrote to the General to employ another Secretary for the work of his office in the place of Sultan Mahomed Khan, whom I kept in my own presence.

A piece of land, named Alam Ganj (the Treasury of Knowledge) was selected by me as a fitting site for erecting manufactories and workshops, because it was outside the city of Kabul and still quite close to it. It was larger than any other piece of land in the neighbourhood, and in addition was considered very healthy. The site commanded a beautiful view, and on one side was a canal to convey water for use in the works for the engines, boilers, etc., and on the lower side was the river of Kabul to carry away all waste water.

I ordered Mir Munshi to take Mr Pyne with him to report to me if they thought the piece of land was suitable for the erection of the works. In short, in a happy moment, after having consulted my astrologers and fortune-tellers, the foundation-stone was laid on the 7th of April, in a lucky hour, after the usual ceremony of distributing alms and sweetmeats to the poor. ${ }^{1}$

${ }^{1}$ There are several professional astrologers employed by the Amir, who give him advice on every occasion : what time to start on a journey ; what hour and lucky star is for the foundation of a new building; in fact, nothing is done without their permission. Even when the Amir is to cut 
Mr Pyne started a few lathes with the drilling, shaping, cutting, and cupping machines, together with the portable engines which had been bought by M. Jérome. After a few months' stay he asked permission to go to England, leaving the machines under the charge of the Indian workmen. $\mathrm{He}$ returned to Kabul after seventeen months' absence, during which time he was busily employed in finding out all particulars about the new machines to be erected at Kabul. I also at that time engaged the services of two English engineers. From this year I commenced to employ Englishmen in many ways under my Government. My object was twofold: first, to have my people taught engineering and other works by Englishmen experienced in such things; secondly, to bring my people and the English in contact with each other, so that the old hatred that existed between these two nations should be removed from their minds, as our Governments were friendly with each other, and the interests of both Governments were identical. I was also desirous that the English people should hear of the progress made under my Government from their own countrymen. The friendly treatment shown by the Afghan nation to all the English men and women who visited

his nails or take a bath must be settled by the astrologers as a lucky hour for the undertaking! When Nasrullah returned from London, though both father and son were longing to see each other, he was kept outside the city of Kabul, because the astrologers said it was not a lucky hour for him to see his father. Sirdar Mahomed Hassan Khan, who was one of Nasrullah's companions in London, says in a joke that his wife had put on her best new dress the day that they were to enter the city, and as they were detained outside for nearly a week, the dress got dirty and needed washing again before she could show it to her husband. 
Kabul proves that we only killed them when we looked upon them as our enemies. When they were employed in my service for the benefit of the nation of Afghanistan, they received every hospitality and courtesy, and were treated as our friends.

The second Englishman who visited Kabul, after Mr Pyne, was named Mr O'Meara, a surgeon-dentist. $\mathrm{He}$ came for the purpose of making a set of teeth for me, and at the end of 1887 , on his return to India, he related all that he had seen at Kabul with great surprise and satisfaction. He said:

"One of the most surprising things was the way in which the Amir worked; nothing seemed too hard or too difficult for him to master. He was always ready to listen to the complaints of his people and to redress their grievances. For instance, one day when he was out riding, an old woman met him on his way to Paghman; she held out her petition, and he at once stopped his horse and beckoned her to approach him. He then read her petition through and asked her many questions, talking to her for some time in the most affable and kind manner. The old dame went away quite comforted and happy. Another day the Amir was talking to me about his financial bothers, he said: 'Only one-fourth of the revenue of my country is paid into my Exchequer; another fourth I can only manage to get by fighting for it! The third fourth comes out of the pockets of my people, but it never reaches mine, while as to the remaining fourth, people do not know to whom to pay it."'

Mr O'Meara left one remembrance behind him in Afghanistan. I placed a clever workman, named Sufi Abdul Hak, under his direction to be instructed in the art of making teeth. I threatened that if he did not learn his profession very quickly and well, 
I should have him severely punished, as it was necessary that he should acquire this knowledge before Mr O'Meara left Kabul. It was not long before he thoroughly mastered the work, partly from fear of punishment and partly because Mr O'Meara did not wish his pupil to suffer, and so took pains to teach him quickly. Another reason may have been that Mr O'Meara himself did not wish to be detained in Kabul longer than was necessary! Sufi has taught several other men how to make teeth and how to extract them with instruments, and this is a very great convenience, as formerly people had to go to other countries when their teeth troubled them. When Mr O'Meara left me, I gave him the gold medal of honour in addition to other rewards.

During Mr Pyne's absence the Indian and Kabuli workmen kept the small factory going on. Year by year the workshops have been enlarged, new ones being erected as occasion required. Machines were bought and placed in these buildings for making MartiniHenry and Snider rifles and cartridges; also saw-mills were built together with machines for all kinds of carpenters' work. I also bought and started the following machines: for making cartridges for the Martini-Henry and other rifles; big lathes; gun boring and rifling; 100-horse-power condensing engines with boilers; steam hammers with boilers; boot-making and leather-sewing machines; powder-making manufactories; soap- and candle-making machines; stamps and dies for coining at the Mint; distilling apparatus for wine, etc. ; tanning and dyeing leather; agricultural and gardening implements; furnaces for smelting ore 
and metals for making heavy guns and for blacksmiths' work; machines for making swords, cartridge caps, and for loading and filling the cartridges; machines for casting and making shells for mortars and heavy guns and various other machines. I continue to increase the stock of machinery every year by buying new inventions as I find need for them.

The difficulties that I had to encounter on first opening the manufactories and workshops were enormous. My people knew nothing of modern inventions and appliances, and were consequently opposed to all these new ideas. I will give an example to show my readers to what extent this ignorance extended. About the time of my visit to Rawal Pindi, in 1885, one of the photographers had placed his camera in position to take my photograph, when one of my highest Court officials, the Kabchi Bashi (Assistant Usher), rushed up to the camera and placed both his hands over the lens. "Why do you do that?" I asked him. "Oh, your Royal Highness, you do not understand? This is one of the new-fashioned guns that this man is aiming at you!" I laughed heartily, and said: "Oh, Rish Safed (grey-beard), whose heart is dark with ignorance, leave the man alone to take my photograph!" The poor man had never seen a photographic camera before, and therefore could not understand what it was, though I tried to explain it to him, but had to give up at last.

When I first opened the workshops my people made all kinds of remarks; they said that I did not know that the work could be much better done by hand than 
by machinery. They accused the officials who were working at the factory of being enemies of the Government, who wanted to send the money out of the country under the pretence of buying machinery. I was very tired of all this nonsense and opposition, but, all the same, I would not give up my determination to proceed on the road I had marked out for myself. For I knew well that unless I had the same sort of guns, rifles, and other war materials that were used by other nations, it would be impossible to keep the integrity of my Government intact, and to proteet the country from the attacks of foreign aggressors.

There is no doubt that it took a very long time to reap the fruits of all this expenditure on machinery; all these large amounts had been paid out of the Government Treasury, and I could not help calculating the interest on the money which was paying nothing for years, being all sunk in the factory and workshops. But I did not lose heart. I continued to buy every year as much machinery as I could find the money for, and as the machines increased I had new factories built to receive them. This I continue to do year by year, so that my commerce and industries are very greatly enlarged and increased.

Praise be to God that I was always fond of machinery and manufactures, and knew their full value! I knew that it was a case of having steel to cut steel, and that if I wanted to fight an enemy on equal terms, I must meet him with weapons of the newest pattern and of the same kind that were used against me.

"If a gentle-armed person fights with an iron-arm, It is sure that the iron arm will break the gentle arm." - SADI. 
For this reason, when my workmen were at a loss to know how to make a certain arm or weapon, I taught them how to make them, and by my instructions and their own exertions, they eventually succeeded. I could give many examples of this kind; I will give one or two by way of illustration.

In 1893, when Lord Lansdowne's Government stopped my Hotchkiss guns in India, my workmen said that it was impossible to make the guns without having models to copy from. I accordingly ordered Mir Munshi to translate the particulars, designs, and measurements of the pieces of the Hotchkiss guns from English into Persian in my presence; and he had to give me the length, width, thickness, and shape of all the various pieces of the gun written down in Persian. When he had finished his part of the work he explained it all to me in Persian, and I then had all the foremen of the Indian and Kabuli workmen brought into my presence. I then instructed them how to make all the pieces in wood; and then they were examined to see if the various pieces fitted properly. The gun was then tested by having wooden shells thrown from the barrel in the same way as would be done from a real gun. This having been satisfactorily demonstrated, I ordered that a gun should be made after this model, but of the same materials as those used in the real Hotchkiss.

In fact, we succeeded in making the gun exactly like the model, without having any other sample but this wooden one to work from. The gun was fired and tested, and stood the trial perfectly. I then thanked and praised Mir Munshi and the workmen, 
and gave them 12,000 rupees in cash, together with the khilats (robes of honour). At the time when Sir Mortimer Durand and other officials of his mission arrived at Kabul they could not tell the difference between the gun made at Kabul and the European ones.

In the same way we succeeded in turning out Maxim, Gardiner, and Gatling guns from drawings and designs, the instructions and all particulars being translated into Persian; in this case we had, in addition, samples to copy from.

Praise be to Allah! At the present day there are about 100,000 men employed in Afghanistan in the work of road-making, building, manufactures, industries, mining, and many other branches of work, all of which were introduced by me. This demonstrates the great progress made in my country, and also that all these men are enabled to earn their livelihood, by being employed usefully instead of as formerly in burglaries, robbing and plundering the earavans. They had no other occupation in those days, and had to get their living as best they could. There is a saying that "Satan finds business for lazy hands," and our Prophet says: "El Kasib habib Allah" $=" \mathrm{He}$ who works is beloved by God."

My sons and successors must not consider that all the benefit that accrued to my country was in the making of war materials; these industries are the source of great enrichment to my country and in the promotion of trade. Money which would otherwise go to foreign countries is spent in Afghanistan. If my subjects are rich, it makes the Government strong 
and powerful and secure, as many of the disturbances that occur are owing to want of money and occupation. Those people who possess property are naturally anxious that there should be no interference with them by wars and rebellions, and they see that it is much better to grow rich than to spend their time in plundering.

Many other kinds of machinery were also bought and put into use; for instance, a small portable engine and a few miles of railway line, and a traction engine for dragging heavy guns.

I have also established electric-lighting works and telephones, employing first some Indian and Kabuli workmen who had been taught this work in India. $\mathrm{Mr}$ Brown made afterwards more progress in these works in 1894, his most successful results being in the electric lighting.

\section{Mint}

At the beginning of my reign, the Mint was worked on the antiquated system existing for centuries, viz. casting and coining the rupees by hand without using any machinery.

The old rupee had on one side the words: "Zarb-idar ul sultana Kabul," and the year of cqining (= "Coined at the eapital of Kabul"), on the other my name was inseribed "Amir Abdur Rahman," but without any motto or coat of arms. In the year 1896, however, the nation of Afghanistan gave me the title of "Ziya ul millat waddin" (="The light of the nation and of 
religion"), and all money coined since then bears on one side the above words, and on the reverse my coat of arms. The copper coins are pennies and two-penny pieces; the silver coins are rupees $(=12 \mathrm{~d}$.), kirans (=half a rupee), tangas (= one-third of a rupee).

Mr MeDermot, who had worked at the Government Mint at Calcutta, taught my Kabuli workmen how to make these coins, and since he left, his pupils have carried on the work without any superintendence. From 80,000 to 100,000 rupees can be easily turned out every day in my Kabul Mint. Not only do my workmen coin the rupees, but they also make the dies and stamps; and since the first set of tools and dies was brought from England we have never had to buy fresh ones, everything is made in Kabul itself.

\section{Martini-Henry Cartridge-Making}

Originally these cartridges, as well as those for the Snider rifles, were made by hand before I introduced machinery for the purpose. These cartridges were few in number and of inferior quality. Having bought the aforesaid machinery, I engaged the services of $\mathrm{Mr}$ Middleton to make the cartridges, tools, and gauges. He pleased me very much by the way he set about and carried on the work, and he taught my workmen so well, that they can now make cartridges, tools, and gauges perfectly without any supervision. The modern cartridges are made of one solid drawn piece, and can be loaded and reloaded several times. For reloading the used cartridge cases we have made a special 
machine at Kabul itself. The cartridge case, which is expanded and distorted on being fired, is by this machine compressed into its original size and shape; a new cap and fire-hole are then added, and the case is reloaded. Ten thousand cartridges can be turned out of my Kabul workshops daily, and in case of emergency this output can be doubled.

\section{Snider Rifle Cartridge-Making Plant}

These cartridges were also originally made by hand; but when I had bought a complete plant for making them I employed Mr Edwards to do for the Snider cartridges what $\mathrm{Mr}$ Middleton had done for the Martini-Henry. These works, too, are now carried on by the Kabuli artisans without any foreign assistance. The number of cartridges turned out daily in ten hours is 10,000 , which number ean be doubled if necessity arises. $\mathrm{Mr}$ Edwards also taught the men to make gauges for guns, shells, etc. I may say that the same cartridges as those used for the Martini-Henry rifle can also be used for the Maxim, Gatling, and Gardiner guns, as the barrels are specially designed to take the same size of cartridge.

\section{Martini-Henry Rifle-Making Plant and Machinery for Making other Small Arms}

Rifles were made by hand at Kabul before I introduced machinery for this purpose, but there VOL. II. 
were the same disadvantages as those attendant on hand-made cartridges, viz., they were inferior in quality excepting those made by very clever workmen, and of these the number was very limited. I therefore bought a complete plant for making MartiniHenry rifles. I engaged the services of $\mathrm{Mr}$ Cameron, who had been employed in the Indian Government factory at Dum Dum. He not only carried out his work thoroughly and taught the artisans how to make everything, but he also made several improvements in the cartridge works; also in the gun works, and the various small arms factories. I believe he was the cleverest engineer in making guns and small arms who ever entered my service. My Government has benefited very considerably by his work. He taught the Kabuli men as much as he could, and took the greatest interest in doing so. He gave me a list of special books and treatises on making, testing, and using all sorts of war materials. These books could not be bought in shops, so the list was sent to my envoy in India with instructions to get them from the Indian Government. On my requesting the Foreign Secretary of India through my envoy, Colonel Wali Ahmad Khan, the books were obtained, and some of them have been translated into Persian.

By means of this new machinery fifteen MartiniHenry rifles can be turned out daily, all complete, and the number could be doubled if necessary. Though the machines can only be used for making Martini-Henry rifles, the same lathes, drilling, rifling, and turning machines can be used for making repeater rifles, Lee-Metford, and other guns and rifles, by 
substituting new tools and instruments, just in the same way as in the coining process gold and silver coins of any size can be made in the same machine by changing the dies.

\section{Engines, Boilers, Blacksmiths' and Gunners' Work}

As above mentioned, guns were made by hand before the introduction of machinery, and the engines that I bought at first were small portable ones that did not require separate boilers. I was therefore obliged to buy a large condensing engine of 100 horse-power, together with its boilers, for the purpose of carrying on the workshops on a larger scale. I also thought it necessary to buy a large steam hammer and boilers at the same time as I bought the cartridge plant, the Mint machinery, and the soap and candle machines, as they all required boilers. For these needs, as well as for the gun-making furnaces and other blacksmiths' work, I employed an old experienced English engineer, named Mr Stewart. $\mathrm{Mr}$ Stewart was not only a man of very great ability and experience, he was also very hardworking, willing, and full of wit and humour; and, though an old man, he was very energetic and active about his work. $\mathrm{He}$ started all the abovementioned works, and thoroughly instructed the Indian and Kabuli workmen in their use, and now, to my very great satisfaction, these artisans can make engines, boilers, and furnaces by themselves. One of the Kabuli foremen of the moulding department, named Salam, a carpenter, made a wooden condensing engine, 
aided by a few other men. It was exactly like the English condensing engine, and when it was completed, and I found that it worked satisfactorily, I doubled the salaries of all those who took part in its making. I gave them in addition 6000 rupees in cash, with khilats (robes of honour). This reward from me encouraged another workman called Kasham, an engraver and draughtsman, to make another small engine, not in wood as the carpenter had done, but in the real materials-iron, steel, and copper. Fire and water were put to this engine in my presence, and it turned a small lathe. The maker of it was rewarded for his clever skill. All the furnaces for making heavy guns, for softening the cartridge metal and silver for the coins, as well as the steam hammer, casting furnaces and various other works coming under the heading of blacksmiths' work, are now carried out by the Kabul workmen by themselves. I am greatly satisfied with Mr Stewart's work in this department.

I will say a word or two to the credit of the Indian and Kabuli workmen for the way in which they carried out their duties and continued to keep the workshops going during the absence of Mr Pyne. More than half the time he was in my service he was out of the country, being obliged to go to England on account of the extreme cold of the Kabul winters. In addition to starting the workshops, $\mathrm{Mr}$ Pyne performed other services, which will be mentioned elsewhere.

Some people will wonder how we got these immense pieces of machinery, the heavy steam hammer, the 28- 
feet-long lathes, large engines, and other heavy pieces of machinery, conveyed to Kabul, no railway being in the country. But though the difficulties of transit were very great, my determination was greater still.

\section{Distilleries}

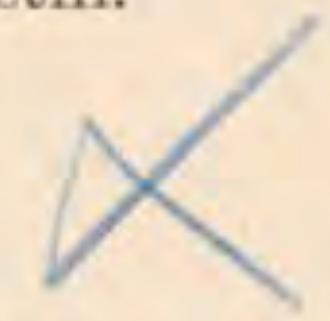

The spirits required for making fulminate of mereury for the cartridge caps and other purposes used to be distilled by hand in small quantities, there being no machinery for the purpose. There were great quantities of grapes, raisins, and such like in Afghanistan, and I considered that it would prove to be a profitable business if I established a distillery for refining wines, etc. I therefore bought machinery and erected a distillery on a sufficiently large scale to produce 1500 bottles of wine in eight hours. I also opened a distillery for making brandy and other spirits: these wines and spirits were intended for export or for sale to such of my Afghan subjects as were not Muslims.

Before I established this manufactory, the distilling had been carried on by some Armenian Christians who resided at Kabul; after a time other people took up the work, and the nobility and chiefs followed suit, these last carrying on the process in their own houses. As neither the teachers nor their noble pupils knew anything whatever about wine distilling, the stuff they produced was such a vile mixture, that those who drank it were afflicted by various diseases, and their general health suffered. As it is against the Mahomedan religion to take wine, I inflicted severe 
punishments on all who made, sold, or bought any wine whatever. These restrictions broke the people of the bad habits of drinking, into which they had fallen during the reigns of Shere Ali and Azim Khan.

I next appointed a few Kabuli workmen, who knew the old way of distilling, they having worked under the Armenians, to learn the newest and best methods, their instruetor being an Indian distiller, named Ram Singh. This work also is now carried on by my people without any superintendence from foreigners.

\section{Tannery}

During the time that I was so busy in buying and establishing machinery for making guns and weapons for use in time of war, and for commercial goods, I was also paying much attention to the fact that the materials required for the daily consumption of the workshops and factory machines should be of native production, so that I should not be compelled to go to foreign countries for raw material to be worked up in my establishments. The money spent for this purpose every year would thus be kept in the country instead of enriching other nations, and any profits would go into my treasury chests for our own use. To attain this object I opened various works at Kabul for making and producing such materials for use in the workshops. I am considering this subject with the greatest attention at the present time, because at one time the Indian Government stopped all such materials as were required for making arms and ammunition being brought into Afghanistan from India. This taught me 
the lesson that it was no use having workshops and factories for making these articles, unless the materials for making them were produced in Afghanistan itself. We are thus quite independent of other countries in this respect, and this is a great benefit to have secured; because any of the great Powers could at any time stop the importation of steel, iron, copper, and brass, and the workshops would have to be closed. So I have introduced all the necessary machinery for digging out the minerals from the earth, and for iron, steel, and lead smelting, and for copper, brass and coal mining; all these works are being improved as time goes on, and as I can avail myself of the new processes.

One of the most expensive items to purchase was tanned and dyed leather from India or from Europe. The consumption of leather was increasing day by day, as the workshops became more and more extended. Many articles were required for artillery purposes-boots, belts, leather belting for machinery, bridles and harness, and other miscellaneous requirements. To meet this want I bought all the necessary machinery and tools for tanning and dyeing all kinds of leather, and now, by the grace of Allah! leather is tanned and dyed at Kabul by the various processes in use in England, India, Persia, and Russia. Among the foreigners, those who most distinguished themselves in this department were Mr Tasker, an English tanner. He taught Azim, the foreman of the Kabul tanneries, all the processes in leather manufacture, as carried on in England, and this industry has ever since been worked entirely by my native artisans. Another Englishman, Mr Thornton, taught Ghulam Haidar, the foremost among the 
Kabul dyers, the use of all the English dyes; this work also is now carried out exclusively by Kabuli workmen.

For the Persian leather, specially tanned and dyed at Hamadan (a town in Persia renowned for its leather trade), I engaged two workmen from that place to teach their processes to my workmen. I followed the same procedure in the case of the Lahori leather, and in this the Kabuli workers are very clever, working quite as well as the Indian artisans. I knew how to make Russian patent leather myself, and I myself taught my workmen how to make it. I am very greatly pleased with all those who have taken so much pains in teaching the tanning and dyeing works to my men, and I am especially grateful to the Persian tanners of Hamadan in this respect.

\section{Boot-Making and Leather Belting for Machinery}

Although the leather was now tanned and dyed by my own workmen, there were no men capable of making it up into boots, leather belting, etc. I therefore employed a man named Ahmad, an Usbeg Russian subject, for the purpose of making and teaching the Kabuli men to make these articles on the Russian models. This man was on his way to Mecca, to which place he was making a pilgrimage; he therefore did not wish to stop at Kabul. I thereupon argued with him, and proved by all the traditions of Mahomed that to do services to other human beings was far better than going to Mecca; and I quoted the following sayings of one of the greatest saints, named Abdullah, 
that "to say many prayers is to be lazy and escape business; to keep many fasts is to be economical and save the food; but to help each other is the worship of heroes,"-in short, he was persuaded to enter my service, and he has taught his trade to my workmen.

One of my own cousins, when living in exile in India, had learnt the trade of boot-making; his name was Sirdar Karim Khan. I persuaded him, after some reasoning and argument, that it is no disgrace for a member of the royal family to work with his own hands, as believed by the ignorant Afghans; on the contrary, it is a disgrace for a person who cannot work at all. I told him to join another man, a Hazara prisoner of war, who had learnt the bootmaking trade somewhere else, and together they started this trade at Kabul. Many other shoemakers have learnt from them, and by the aid of the leather sewing and boot-making machines bought by me, thousands of boots are being made every day in the Kabul workshops, as well as in other towns, and they are now being sold in Bazaar as well as to the soldiers in my army. The money which was being sent annually abroad for the purchase of boots, leather belting, harness, and other articles, now remains in the country, which is a distinct advantage. I intend issuing an order that no boots or other leather articles shall be allowed to be imported into the country, and that people requiring these things must buy home-made goods. I must wait for a while, however, before issuing such an order, until a sufficient number of people have learnt how to make the goods, so that there may be a continuous 
supply to meet the demands. I have given an order that no raw leather shall be exported from Afghanistan without having a special letter of permission from the officials of my Government. It was a ridiculous thing that the leather of my own country should be sold to the people at four times its proper value by having to be sent out to other countries to be tanned, dyed, and made up.

\section{Soap and Candle Making}

I started this industry in various provinces at first by hand. There is any amount of fat for the purpose, the people being all flesh-eaters, and especially in the cold parts of the country the fat of the animals does not waste so quickly as in hot countries, where the sheep and cows have very little fat as compared with those in cold countries. A large portion of the fat used to be thrown away as waste refuse before I introduced the soap and candle making. But both these articles made by hand were simply boiled fat without anything added to turn them into properly made goods. Now, however, I have all the proper plant necessary for making soap and candles, and this department is a source of considerable income to the Government, though it has not been extended and improved as much as I could wish as yet. I intend opening soap and candle factories in every important town in Afghanistan, to save the expense of freight and cartage from one town to another. I have for the same reason opened branch establishments for casting shells at various 
places in the country, thus saving the heavy cost of conveyance. The hand-works for making soap and candles are carried on at present in all those provinces yet unprovided with machinery. Here, again, the money that used to be spent for foreign goods is now retained in the country.

\section{Master of the Robes and Tailoring Department}

In former times all the people of Afghanistan, from the King downwards, including all the military and civil officials and chiefs of the country, used to wear tremendously big trousers, and sleeves yards wide, so that for one pair of trousers fifteen yards of white calico were required. This was a great piece of extravagance; it was also very hideous and against the direct commands of Allah, who says: "Inallah la yahib el musrifin" ="Indeed the true Allah does not love those who are extravagant."-Koran.

Besides being extravagant, this stupid fashion made the people lazy and unable to move about without dragging along yards and yards of stuff hanging behind them. To put an end to this I employed several Indian tailors who were formerly employed in the business of making English uniforms for the troops in India. I placed hundreds of tailors under their instruction, who made uniforms which I supplied to the soldiers as well as to the civilians; the price of these uniforms I deducted from their pay. I then gave orders that all people who appeared at their duties wearing these long ugly trousers should forfeit six months' pay. I was not quite 
satisfied with the cut of the Indian tailors; I therefore employed an English master tailor, named $\mathrm{Mr}$ Walter, who gave the last finishing touch to the tailoring department. $\mathrm{He}$ and Mir Munshi together wrote a book giving all the designs and drawings of the various ways of eutting and sewing the suits and uniforms used in England. This book gives also all the necessary rules for taking measurements, and states the exact quantities of cloth required for soldiers of different heights and sizes, so that the tailors cannot steal the stuff because the accountants can calculate according to these rules how much stuff is required for men of various sizes.

All the civil and military officials of my Government ean be easily distinguished, and the office or rank of each is indicated by his uniform. All civilians, for instance, ehiefs, governors, officers, heads of various departments, secretaries, and courtiers, wear uniforms just as do the military officers of the same rank who receive the same monthly pay. In this way civilians wear the uniforms of a commander-in-chief, a general, a brigadier, a colonel, a captain, lieutenant, etc. At my durbar also they have their proper seats assigned to them in accordance with the pay they receive and the positions they hold in the Government service. A book especially treating of the rules and regulations attaching to the various uniforms, and of seats of the various civil and military officials at the durbar, according to their positions and rank, has been written; this book is in the possession of my son, Habibullah Khan, and it is a part of his responsibility to see that every person in his durbar, as well as in my 
own, appears in his proper uniform, and takes his proper seat as appointed. For instance, any civilian whose pay is 12,000 rupees Kabuli a year, or above that, ranks with the commander-in-chief. For 8000 he ranks with a general and deputy commander-in-chief; for 5000 , with brigadiers; for 4000 , with colonels; and so on.

There may, perhaps, be some people, fond of finding out the faults of others and not noticing their own, who make the remark that I am a moneygrabber! I have heard such reports more than once. They say that I collect every penny from every possible source, rightly or wrongly. I will say in answer to these remarks that I need not concern myself to reply to such nonsense. The safety and protection of the country depend largely upon the army and war materials being kept up to a proper strength. This cannot be done without money; and though I collect more revenue and money from the country than any former Amir, I also pay the soldiers better than any Amir who preceded me. I refer the people who pass these remarks to the poem quoted by our greatest religious saint and leader, Khwaja Ahrar of Herat, which runs thus: "Indeed no lover of God is a lover of money, but a lover of money for the sake of God is a lover of God." ${ }^{1}$

${ }^{1}$ In this poem the Amir refers to a story written in the Eastern mystic books, that the above-mentioned saint was one of the richest men in Central Asia in those days, about 400 years ago. One of his disciples who had travelled a month's journey, believing him to be a saint, lost his belief in him as he thought that he was a lover of money. One day, however, a poor widow came to him and said that her only child was ill, and the only remedy to cure her, prescribed by the physicians, was to give the child the roasted liver of an Arab horse ; this liver was also to have two white 


\section{The Press and Education}

Before my accession to the throne there was no typewriting or printing press throughout the whole dominion of Afghanistan, and education was so neglected that I had to advertise all over the country for thirty clerks who could read and write their own language. I could, however, find only three to fulfil these conditions. Praise be to Allah ! thousands of my people can now read and write, and thousands of copies of various books furnishing information on various subjects, forms of papers, stamps, promissory notes, etc., are printed and published by the Kabul Press. Schools are being opened in all the towns, and in every regiment of the army, for the education of the people, and, God willing, a college will soon be established at Kabul for the teaching of various sciences and systems of education according to European methods. I have also ordered the people of Kabul to unite together and issue a semi-official newspaper at Kabul.

The man who deserves great praise for opening the press at Kabul was the late Munshi Abdul Razak,

spots. Thereupon the Khwaja offered the woman an Arab horse of his own to be killed without charging any price for it, as she was so very poor. But when the horse was killed there were no white spots; so the saint ordered another horse to be killed, but still no white spots ; and so on, until 101 horses had been killed, when at last he pleased the widow by giving the liver as required. This generous act of the saint caused the disciple to change his opinion, who now knew that he kept his money for the use of the poor and suffering. Then the saint, having been inspired about the feelings of his disciple, repeated the sentence quoted above to him, which made him more devoted than before to the saint, so impressed was he to find that the saint had been inspired to know what was passing in his mind. 
of Delhi; he died of fever, but the printing and press work are being carried on by many Kabuli men taught by him, and in remembrance of his services I give his full pay to his sons and widow.

\section{Miscellaneous Manufactures and Industries}

If I were to give a detailed list of all the works introduced by me it would take up a very great space. It will be sufficient if I give, in addition to the works already mentioned in this chapter, the following which have been, or are being, started in Afghanistan :-Hat-making, both European and Eastern models; machinery for making telescopes and distancefinders for the artillery; heliography and all the things necessary for the requirements of this art (nothing whatever was known about it before my time); powder and shot-making; for making gold wire machines, and gold lace; machines for making Persian and Indian carpets; curtains and chairs; for weaving and making turbans; for tents; for electro-plating and gilding; for war materials of all kinds other than those before-mentioned, such as sword-making and percussion-eaps and fuses; revolvers; lances; enamelling and paper-making; acid-making machines; book-binding; biscuit and cake-making; lanterns; glass-making; machines for needles and tailors' work; casting furnaces for silver, copper, brass, steel, and iron; furnaces for baking bricks and lime ; for various works of architecture and carpenters' work; stonecutting and making floors of stone after the Mogul designs on the Delhi buildings; oil-mills; machines 
for making bag-pipes, bugles, and other instruments for military bands. ${ }^{1}$

I have also made an arrangement whereby prisoners of war and prisoners for various serious offences who know how to do any kind of work connected with the industries and manufactures, shall be placed under the head workmen of their trade or profession; and when they have thoroughly learnt the work they shall be released from prison, and employed and paid for their services according to their merits and abilities. They are paid exactly the same money as an ordinary workman would be paid. By adopting this plan I contrived to collect a large number of workmen, as I could not force my subjects to accept the employment in my workshops. The prisoners were only too anxious to be released; they therefore learned their work quickly, and received their freedom and reward by being paid for their work, I, on my part, getting good and grateful workmen.

${ }^{1}$ In Kabul all the military bands are exactly the same as those used in every regiment of the British army, and the books on bands and military discipline have been translated from English into Persian. Every officer in charge of the various departments has to pass an examination before being admitted into the army or department, whatever it may be. 


\section{CHAPTER III}

\section{GOVERNMENT DEPARTMENTS}

I Do not wish to trouble my readers with too much detail, but the book would be incomplete if I omitted any information as to the many ways in which progress has been made during my reign. The fact is, that so little really accurate information about Afghanistan is possessed by the world generally, that very much that I shall tell them will be perfectly new, and heard of for the first time. It is plain to me that some foreigners who have visited Kabul from time to time have given the world false impressions, by posing as great authorities on Afghan affairs, internal and external. I am very often amused by reading articles written by them, because it is quite evident that they have never approached the borders of Afghanistan nearer than 500 miles. It is therefore necessary that I should give true information, if not in detail, yet as much and as varied as possible. My time is very fully occupied, but I will spare a little for this purpose from my numerous duties and engagements.

Before my accession to the throne, the various departments of the Government were so mixed up with each other, that one could hardly say whether VOL. II. 
there were any departments. For instance, there was one man, named Mustauf (he may be called Prime Minister, Paymaster-General, Accountant-General, or anything else). This man had a small staff of ten clerks or thereabouts, and he carried on the administration of the whole kingdom in his bedroom; there were no public offices at all. I sometimes hear people say: "Oh, that was a very good system, to have no public offices, and everything so simple that one man could conduct the whole business of the kingdom!" Such remarks show that the speakers do not know anything of the administration of Governments, and their utterances are not worthy of attention.

One thing is very certain, that the Government that could be so carried on must have been a very small affair, requiring as it did fewer clerks for working out all its details than are employed to keep the accounts in any wholesale shop. Another point is that great opportunities for swindling and giving arbitrary and unjust decisions were in the power of this one man; he could do rightly or wrongly without fear: his accounts were never checked. It is this sort of carelessness, owing to laziness and neglect of duty and the ignorance of rulers in the past, that is one great cause of the downfall of so many Eastern kingdoms. All men are liable to make mistakes, we all have our weaknesses as well as merits, but so long as a ruler or head of a department keeps himself informed of everything that is going on, and works himself as hard as any of his officials, if not harder than any, there is hope of him making some progress. In too many cases it happens, as with some of the 
Indian ruling dynasties, that the princes and rulers are hardly to be seen outside their harems for months at a time; how, then, can their subjects bring their complaints before them to obtain redress for injustice and grievances? As the poem says:

"How can the cry of the sufferers reach thine ears;

Thou who sleepest in high palaces where no cry can come."

$-\mathrm{S}_{\triangle \mathrm{DDI}}$

I must say that, to my very great regret, Afghanistan has not yet been properly organised into departments for carrying on Government business. Very often my troubles are caused by officials not knowing their own business, and mixing the work of one department with that of another, and trying to extend their jurisdiction to things quite foreign to their own special office. I trust, however, that as Afghanistan has made such rapid strides towards progress in so short a time, its public offices and works departments will soon be put into proper working order.

I have divided the departments and institutions of my Government under two headings: (1) Military, or Nizami; (2) Civil, or Mulki. Every person is practieally a soldier, and Ghaza $^{1}$ (to fight for the truth and faith) is every citizen's bounden duty; every true Muslim must fight for his religion.

\footnotetext{
${ }^{1}$ Some people are ignorant of the meaning of the word Ghaza; they imagine that every true Muslim is bound to fight against infidels and those people who are not Muslims without any cause. True Muslims must understand that Ghaza means "to fight a defensive war in the case of any nation trying to take their country or stop their religion, and no Ghaza (religious war) can be fought except under the orders and instructions of the ruler of the country."
} 


\section{The Military, or Nizami}

Before giving the list of the various departments of the Nizam, I may say that all the industries and manufactures for making war materials and ammunition, mentioned in another chapter, are under the Military Department. The workmen and foremen take their pay from the Military Secretary's office. Most of the foreign employés and workmen, Indians, Englishmen, etc., take their pay from this office, the reason being that pay from the Military offices is given monthly, regularly, and in cash, paid out of the Treasury for this purpose. The pay of civilians, on the other hand, is generally given from the revenue of the country. An order is given to the civilian from the Exchequer, under the seal of one of the heads of the Revenue Office; my own seal is also attached to this order. Salaries are paid in this way perhaps only once a year, sometimes at the end of six months. They are paid for the whole year in advance. These orders are called Barats, and the civilians have to go and collect the money themselves from those who owe it to the Government Exchequer, either in taxes, customs duties, or land and property tax.

It would be undesirable to give the number of my troops in this book; I will merely give a short sketch of the various departments of my army.

\section{The Departments of my Army.}

(1) Artillery; (2) Cavalry; (3) Infantry, Police, Militia (called Khasadars), Khwanin Sowars (militia 
cavalry attached to the chiefs of the country in proportion to the land possessed by them, or allowances paid to them by the Government), and Volunteers. The last-named heading includes every man over the age of sixteen and under seventy. It is arranged thus: The people themselves send one man out of every eight, and pay all his necessary expenses during the time he is occupied in learning drill and military training. After this he retires to his farm or other occupation, and another one from the eight men is placed in the training-school in his stead. This system was only instituted in 1896 at the request of the people themselves. I am myself bitterly opposed to enforced service; I do not wish men to do anything against their will, or be employed in the army unless they wish. The Afghan people are credited with being good warriors, and every one is a thorough soldier, but without proper drill and training and discipline, however brave they may be, they could not fight against the skilled and organised armies of modern European nations. I am therefore glad that this system has been introduced, and now that my people have a proper army to fight for the country, and money to buy provisions for the troops, I trust in Allah that they will not fail in defending their land from even the attacks of the greatest empires who might wish to possess themselves of it. They will thus prove that the Afghanistan of the past was a dream that is gone for ever. This reminds me of an ineident that occurred at the time I was living in exile in Russia, and I will give a short account of it here. 
The Russians had brought up a very heavy gun to practise the destruction of forts. I went to watch them, and a Russian officer told me that the gun was brought to attack, break, and take the fort of Herat. I replied: "If Providence has the kingdom of Afghanistan written in my Kismet (Fate), then the very place where this gun will fail will be Herat, but if I am not to be the ruler of Herat I cannot tell what will happen." The Russian answered contemptuously: "You live on the allowance of our Government, why do you say this?" I replied: "I have not accepted the allowance as a compensation to sell my country, nation, faith, and spirit of patriotism; I am not one of those cowards who can hear of the destruction and ruin of Afghanistan without giving an answer. If you do not want to hear the truth, it would have been better for you not to speak about this gun."

The Afghans, who are born warriors and accustomed to fight from their youth, in ancient times used to fight in the following manner: Every chief, landowner, Syad (descendants of Mahomed through his daughter Fatima), and eminent priest, had a number of followers who used to take a flag and a drum, called Dhul, and a flute, called Surnai, and when they beat this drum and played the flute, thousands used to join them and start for the war. These drums and flutes were their bands for the battlefield, and when these were sounded every true Muslim was bound to join under one flag or the other. Their drill consisted of nothing but a cry, "Allah Akbar" (="God is great and powerful"), or "Ya 
Chahar Yar" (=the Four Companions of Mahomed). This is how their wars were carried on. Their weapons were guns of brass or copper, muzzle-loading muskets, old-fashioned revolvers, Persian and Gujerat-made swords, Afghan sabres, called Sailabas. Every person was a Ghazi or soldier of the Faith. Even at the present day every Afghan prays when he goes to bed that the Almighty Allah will give him the death of a soldier on the battlefield, and not on his bed; that he may die fighting for his faith as a Shahid ( $=$ one who gives his life for his religion). It is our belief that all who die as Shahids go to Paradise without being asked for any account of their doings before the Almighty Judge at the Day of Judgment. Those who are Ghazis are considered innocent in the sight of God.

This old system of fighting lasted until the present century; before my grandfather's time the composition of the army was simply a mass of fighting men consisting of cavalry and infantry, but without any organisation into proper batteries, regiments, or battalions. My father laid the foundation for organising them into proper divisions, columns, batteries, cavalry, and regiments, under the orders and instructions of my grandfather. He was greatly helped by a European military officer, mentioned in another part of the book, named $\mathrm{Mr}$ Campbell, and other Indian military officers of the British and Mogul army, who had left that country at the time of the Mutiny and joined my father's army. This helped considerably in the organisation of the army. Amir Shere Ali Khan, at the time of his succession 
[CHAP.

to the throne, continued to keep and follow this system, and made some improvements which he got from certain books which were translated into Pushto; these books were in use in the British army. His army, however, was defective in certain respects, one of them being that the soldiers did not get their pay regularly, and had certain privileges granted them of extorting money from the subjects without any punishment being inflicted on them for so doing. The officers were lazy, steeped in indulgence and vices of all kinds, gambling, opium-smoking, Indian hemp-smoking, and other bad habits which cannot be mentioned in this book; my readers would be too disgusted. The worst thing of all was the enforced conscription which caused general discontent in the country. Through this enforced service and the bad behaviour of the officers, his army was in such a condition that it could not stand against the English army half so well as any ordinary chief.

Thanks be to God! now my army is properly organised upon the modern European military method, and my soldiers are paid regularly in cash every two months. Every cavalry regiment and battalion of artillery is complete with its sappers and miners for trench-work, engineers, bands, tents, medical corps consisting of hakíms (physicians) and jarah (surgeons), chaplain, accountant, commissariat department, and so on.

My army is supplied with breech-loading guns of the most recent Nordenfeldt, Hotchkiss, and Krupp putterns, as well as English mountain battery guns, nule battery, Maxim, Gardiner, and Gatling guns. Their 


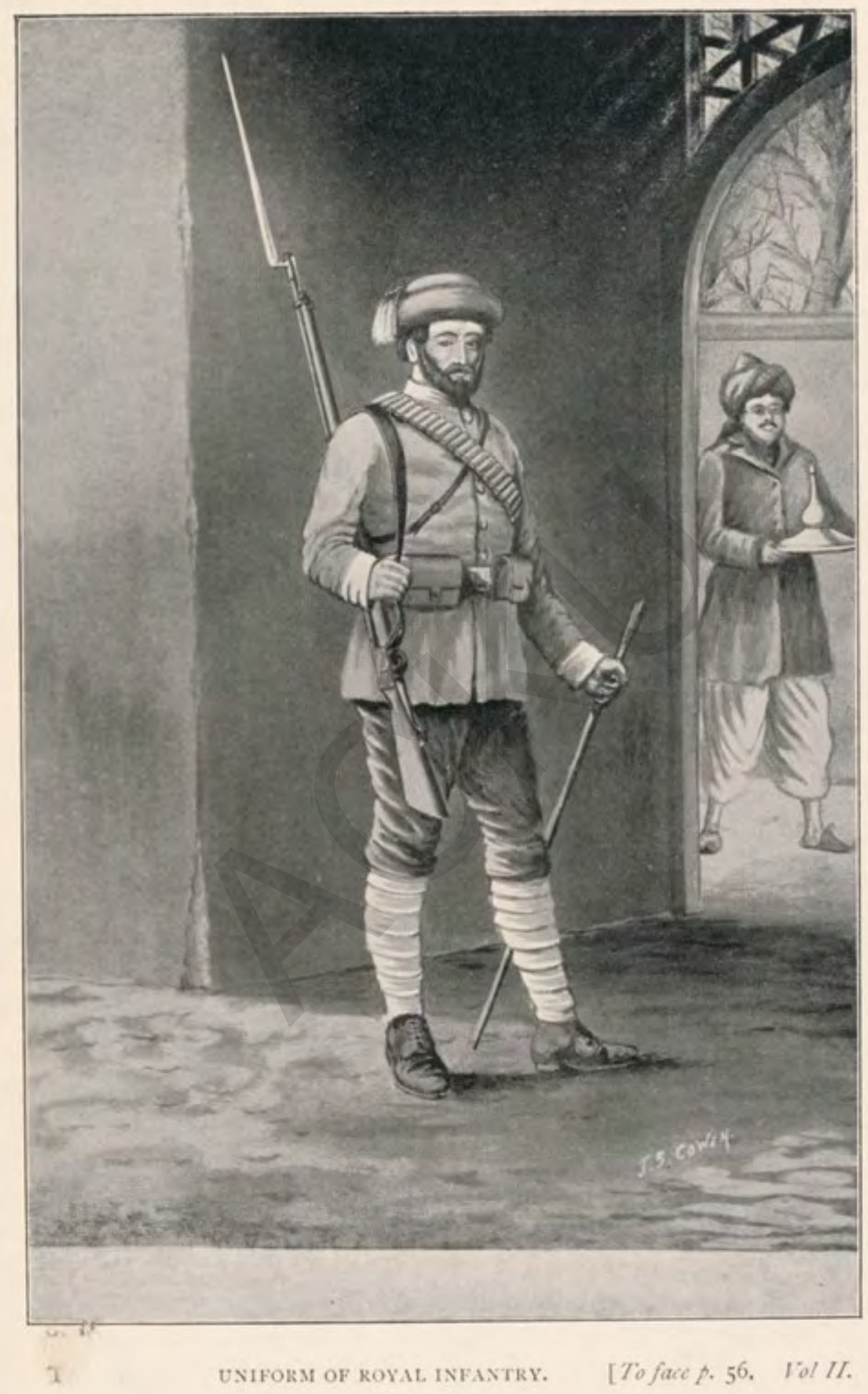



rifles are the same as those supplied to the British army, Lee-Metford, repeaters, Martini-Henry, Snider, together with modern breech-loading guns, such as are used in the German army, of the Mauser pattern. They have also one small breech-loading carbine, as used in the Austrian army, and certain Russian guns of modern designs. The percussion and time fuses of recent English invention are being made at Kabul by the same machinery that is used in England for the purpose. In fact, all the arms and war materials, including shells and cartridges, are ready for 300,000 soldiers, if necessity arises. The stores of food and provisions and money, as well as transport animals, are also ready for an immediate move. I am making every effort to provide myself with 1,000,000 fighting men, all armed with the most modern weapons and war materials, stores and provisions, and pay for two years, to carry on a war that should last for that time. Of course this large number of men is not difficult to find in Afghanistan at a fortnight's notice, but any one who knows anything about war must consider the difficulties of supplying transport, food, pay, and all the necessaries for war for such a large body. There is, however, one great advantage in my favour; the country is full of arms, every man and woman possesses a gun or a sword, and in certain Afghan tribes the brides take their dowry only in war materials. There is splendid transport in the shape of elephants, camels, horses, pack-ponies, mules, and donkeys, and the country is rich enough to supply food from its own resources. The only drawback is money, which I am struggling to accumulate day 
and night. Luckily, we have no national debt, and two nations, namely, England and Afghanistan, whose interests are identical, are provided in this way: England wants soldiers to stand by her side; she has money and arms-Afghanistan has fighting men but requires money and arms, of which England has such an ample supply. However, no foreign power can bring a million soldiers to fight in Afghanistan, and provide such a large body to continue a war for a long period. The advantage that the Afghans possess is, that they are strong men, and can travel in their country as fast as any horse, carrying their tents, powder-belts, rifles, and thirty loaves of bread to last for a month on their shoulders. ${ }^{1}$ I repeat that it would take a very long time before any aggressive power could arrange to move such a great army and plant it in the heart of Afghanistan, before Afghanistan is ready to supply everything that is requisite for a similar force. My arrangements are to provide every gun with at least 500 shells and every rifle with 5000 cartridges. All the rifles that I have bought from England and Germany, and that have been given to me by the British Government, are provided with 5000 cartridges each. In addition to the masses of war materials, which have been bought and given to me by the British Government since my accession to the throne, there are

1 The Afghans bake a special kind of bread and prepare dried food, which can be kept from one year to another. There are two kinds of dried food, called Landi, one kind of food called Talkhan, a mixture of the dried mulberry fruit and powdered roast wheat. Another kind of powdered food is a mixture of sugar and roasted wheat called Satu. The Afghans sometimes live for months on these foods. 
the arms and ammunition which are being made in the workshops, the immense stores of which increase day by day. Some of these are, 360 Hotchkiss and Nordenfeldt breech-loading guns every year, complete with shells, ammunition, carriages, and harness for the horses. What Afghanistan does require very badly is properly trained military officers, to supplement and make more useful its splendid stock of war materials. I am paying every attention to remedy this difficulty as time goes on.

First, I have instituted sham fights, the teaching of all kinds of drill and military tactics, military examinations, learning the use of distance finders for the range of the guns, and other useful hints on military practice. The men take to pieces and put together again all kinds of guns; this is done both by officers and men without any help from artisans; they are taught the proper measurements of powder and the proper application of percussion and time fuses, etc. The sappers and miners are taught, in addition to engineering work generally, to make roads, bridges, entrenchments, sangars; also gunners' work and that of infantry.

As education is a most important branch of an officer's training, they have to prepare themselves for their profession, and become competent to perform their duties. This, as I have said, is tested by examinations. As the poet says:

"The mass of the army is not the only thing required,

Two hundred competent warriors are better than 100,000 noise-makers." $-\mathrm{J}_{\mathrm{AMI}}$

It has been suggested to me in the same way as I have elsewhere mentioned that the best and easiest 
way of conveying the army from one quarter to another would be by railways; and I again insist on advising my sons and successors to remember that the principle on which most nations act at present proves that there is no consideration for right, but only for might; and therefore, as Afghanistan has not arms enough to fight against any great attacking power, it would be folly to allow railways to be laid throughout the country. My Intelligence Department keeps me supplied with information of the movements of the armies of my neighbours, and we could very easily bring any number of fighting men to the frontier before an enemy could reach it with half the number.

I have mentioned that the interests of Great Britain and Afghanistan are identical, which is perfectly true in effect, but as circumstances are liable to change the ideas of every nation, my successors must not relax any effort or vigilance. They should not place their entire confidence in the support and help of Great Britain, as it is possible that that country itself may think fit to change her attitude towards Afghanistan, or it may not suit her views at the moment to help them. My sucessors must follow the true philosophy taught by our religion, which is: "Prepare yourself to face any difficulty, and then place your confidence in God." It would be difficult for Great Britain to break the pledges and agreements which she has given to me to protect the integrity and safety of my country, but it is to England's interest and advantage that Afghanistan should be both independent and strong to act as a barrier between Russia and India. 


\section{Mulki, or Civil}

Every other department, except those mentioned in the first section, come under the heading of Mulki or Civil, and it is not within the scope of this small book to give the full particulars and names of all the various departments. I will mention a few of the most important ones.

\section{Treasury}

The whole of the income of my dominions is paid into the Khazana (Treasury), and all the expenses are paid out of it. The Treasury is divided into two parts: the State Treasury, called Khazana-i-Amirah (or Public Treasury); and Khazana-i-Khâs (Special or Private Treasury). The latter is my own Private Treasury, in which only my private income, from lands, trade, etc., is paid. I take no cash payments from the Government Treasury for my personal expenses except for my food, clothing, etc. I again divide these two Treasury divisions into two sub-divisions, viz., the Khazana-Nakdi (Cash Treasury), and Jinsi (everything except cash). Both of these Treasuries are inside the inner circle of the fort at Kabul, called Arg, or Palace. In the outer circle of this building are the various Government offices and public audience or durbar hall. This palace has a garden nearly as large as the whole city of Kabul around it; neither palace nor garden existed before I came to the throne. The branches of the Treasury are in nearly every principal town and province of Afghanistan, and whatever is 
left in these Treasuries at the end of the year, after deducting the expenses for working these provincial branches, is forwarded to Kabul. If the expenses of any provinces are greater than the income, more money is sent from Kabul to meet them.

To keep myself informed of the income and expenditure of my Government, I have made the following arrangement. Every evening an abstract is sent to me from the Treasury, which shows how much money was paid in during the day, and how much was paid out, and the balance in the Treasury at the time the abstract is made out. I thus know every night how much money I have in the Treasury, and I can also compare the expenditure of former years by this means.

The principal Treasury, as well as its branches, is governed by the President of the Treasury, called Khazanadar (Treasurer), and the Counsellors of the Exchequer. These officials are obliged to render their accounts to the Accountant-General. They give a receipt daily of what is paid into the Treasury, and they take a receipt for all moneys paid out. No money is paid out of the Treasury without orders under my own seal or the seal of my eldest son, Habibullah Khan, counter-sealed by the heads of those departments of the Government requiring the money for the expenses of their departments.

The principal sources of income from which money is paid are as follows :-Revenue on land and fruit-trees; duties on export and import, including various items of customs money. Post-Office: the sale of various 
kinds of stamps for promissory notes, forms for contracts, bills of exchange, etc.; Government trade and Commerce; revenue from the Government lands as well as hire of the Government shops, public-houses, ete. ; fine money, for various crimes and offences; confiscated property or products of the Government minerals; annual subsidy given by the Indian Government amounting to eighteen lakhs of rupees a year. The last-mentioned item is generally spent in buying machinery and war materials from Europe.

The way in which the duties are collected is this: Orders are issued from the various departments informing the people about the amounts owing by them to the Government Treasury, and commanding them to pay such amounts by a certain date, or to any official appointed by the Treasury, and to take a receipt for the money paid. They must then show the receipt to the official from whose office the orders for payment were issued. A copy of this receipt is entered into the books of the particular department, and the original is given back to the payer to keep as testimony that he has paid.

For the army stationed in different provinces and for the Government transport animals, for keeping stores of corn and grass, for the Commissariat Department, and for the expenses of the royal family and other necessities, the subjects are allowed to give corn, grass, or wood for fuel, and to take a receipt for such things; these are deducted from their taxes according to the prices of the market of the day.

The old system of keeping offices in Afghanistan 
was, that there were no books for entering any of the accounts, small sheets of paper, about eight inches long and six inches wide, being used. Each of these sheets was called a fard (single leaf). These small pieces of paper were half-filled by writing at the top, the name of the office, the year and date, and various other unnecessary things, and the other half contained three or four words, then the sheet was full. What could have been entered in two sheets of a book took 100 of these small scraps of paper. In consequence, when a certain item was required for reference, it was necessary to go through thousands of these scraps, which was a very great waste of time. The worst fault of all was that any official or accountant who had embezzled Government money, could easily take a few sheets or one sheet away, and either write another or tear them up altogether.

I have introduced books, and on the first page the numbers of each page or sheet are written and sealed with my seal to the binding of the book, so that no one can take a sheet out of the book without breaking the seal. At first some people played tricks, and tore out some sheets, for which their fingers were cut! Now every one, at the time of taking a book, writes on the first page with his own hands that he promises to have his hands cut if he cuts the book!

The following officers copy and manage all the accounts of the Income and Expenses of the Government. These are connected with the Treasury: Governor's office; Ecclesiastical offices; Municipality and Board of Trade; Kotwali or Criminal Courts office; Kafila Bashi or head of the Caravan office; 
Chabutra or Custom House; the Revenue offices, four in number-Northern, Southern, Western, and Eastern ; Post-offices; Sakukat or offices for selling all kinds of stamps; offices for entering all the daily expenses of the Government (Ikhrajat); office for entering all the income of the Government (called Tahwilat); the Record office, where all the Government papers are kept (Daftar-i-Shah or Royal Records); Rahdari or Passport office; Roznamcha, the office where all copies of orders issued on the Treasury are made, both for paying and receiving money. Hisab Giri, the office for the final settlement of all the accounts (this may be called the Accountant-General's office). This office is governed by two counsels - one is an accountants' counsel, the other is the arbitrators' counsel-to see that the accounts are just and rightly made and paid.

The appeals from the provincial branches of these departments go to the principal offices at Kabul, where they are seen by my eldest son, Habibullah; from him they come to me. There is another office which stands mid-way between the above-mentioned offices and myself, called the office of my Court Secretary, presided over by a Chief Secretary.

There is also the Military Secretary's office, Commissariat office, Nazir's office (the head of the kitchen of the royal household), Workshops offices, Public Works Department offices, etc.

\section{Courts of Justice}

All the departments mentioned in the first section are courts of justice as well, and have their respective voL. II. 
jurisdictions; appeals are made in the same order as I have said before. I need not therefore repeat them; I will say, however, that the courts of law are not the same now as they were before I came to the throne. In certain cases the decisions are according to the Mahomedan law, subject to my approval, but in various matters the law has been changed to meet the altered circumstances and customs of the country. For instance, I have already said that 300 rupees was the price of the life of a human being. I have abolished that law and instituted another, to the effect that a murderer is enfirely at the mercy of the relatives and friends of the murdered person; if they choose to forgive him, the Government still retains a right of granting or withholding pardon. But even if the State does pardon him as well as the relatives and friends of the victim, he has yet to pay 7000 rupees fine as a compensation, to ransom his life. If he cannot afford to pay the fine, his relatives and friends are allowed to pay the ransom if they choose. According to the old Afghan law, the wife was not only considered the property of her husband, but the property of his whole family-brothers and relatives; if, therefore, she lost her husband, his nextof-kin had the right of marrying her against her wish. This was the law of the land; a poor woman, therefore, who had the misfortune of falling into the hands of any family, had no possible chance of escape from them, and it was considered a disgrace to the family if she was allowed to go to her own parents or anywhere else after the death of her husband. The most curious idea was that it was considered to be following the law of Mahomed. This, however, was entirely opposed to 
Mahomed's teachings. The law that I have made is that the moment a husband dies, the wife is free, and she cannot be forced to marry any one against her wish. Not only that, but by my law, a girl under the age of puberty, married by her parents, is quite at liberty, when she attains full age, to accept the marriage or not. Further, even after accepting the marriage, if her husband is cruel to her, or does not pay her expenses, she can sue him to give a sufficient alimony or to give her divorce. In the same manner, some important and influential families used to get their sons-in-law to sign such large amounts of dowry for their wives against their wish, that it was impossible for them to pay, even if his family joined together to help him. For instance, a man whose income was $10 \mathrm{~s}$. a month was made to sign that he would give 500,000 rupees to his wife as her dowry; in default of paying the poor man was made a slave. I placed restrictions upon this law, and settled that the princes of the royal family were to give from 1000 to 3000 rupees for dowry, and other people from 300 to 900 rupees. Of course, if they had private means, and of their own free will chose to give more than this to their wives, they were quite at liberty to act according to their inclinations.

There are some other great changes in the old ridiculous way of administering justice which would require a book all to themselves if I were to give all the details. I have introduced a system of registration of marriages, so that there shall not be any disputes for want of sufficient evidence. If the Registrar should allow any illegal marriage or enforced marriage to be entered in his book, he is severely punished. 


\section{Public Works Department}

More attention has been paid during my reign to this department than ever before in Afghanistan. It shows clearly that there does not exist one building throughout the whole country which was built of Pukka bricks (baked bricks) and lime, or of stone. All the buildings were of mud. The only places where the old buildings can be seen are the ruins of the old city of Balkh, Ghazni, and the palace of Bala Hissar of Kabul, a few tombs seattered about the country, and half-a-dozen mosques or so. I am glad to say that during my reign fine buildings of brick and lime have been erected in nearly every one of the principal towns in my kingdom. Fine roads have been made, and are still being laid out, throughout the country. The principal roads are those from Kabul to Balkh, extending to Russian territory; from Kabul to Herat, from Herat to Kandahar, and thence to Ghazni and Kabul; from Kabul to Hazarajat; from Jellalabad to Asmar and Kafiristan; from Kabul to Peshawar, via Tang-i-Karun. The last-named road took ten years to make, thousands of people being employed in the work. The great advantage of this road is that travellers using it, avoid the difficult and tedious mountain peaks and passes between Jellalabad and Kabul. All these roads, as well as the bridges, are inspected annually and repaired, and trees are being planted on both sides of the roads. The people of every town and village through whose land the roads pass are responsible for the wanton destruction of the 
trees and roads, so far as they pass through their land.

In the same manner, the people of every village and town are responsible for the safety of the travellers and strangers journeying through their province. For instance, if a traveller is killed, or his property is stolen in the vicinity of a town or village, the people of that village are either to find the wrongdoer or answer for the injury themselves. Therefore a man of loose character does not find room anywhere in the whole country, because wherever he goes the people say that they cannot answer for his misdeeds, and he must go to another place further away! This is the reason why all the roads are now so safe for travellers throughout the whole of my dominions, though there are no people to look after the safety of the caravans. Of course I must give credit to my Detective Department, and various other arrangements, which have put an end to the everlasting danger which travellers and strangers had to suffer.

I have also built round some of the principal towns strong forts and defences-for example, the fort of Dehdadi near Balkh, commanding the road leading from Russia to Balkh; this is the largest and strongest fort that has ever been built in Afghanistan.

I have started several furnaces for baking bricks and kilns for burning lime; the public works improvements are a credit to all the officials who have taken a part in them. Some of these officials are Abdur Rahman Khan, overseer; Abdur Rahim Khan, overseer; Abdur Subhan Khan, surveyor; Mir Imrad (head of the Public Works Department); Munshi Nazir; 
Munshi Mahomed Bakhsh, who was the head draughtsman of the Punjab Government before he entered my service, and taught drawing to several Kabul draughtsmen by my instructions.

\section{Medical Department}

This department has two branches, the old one called Yunani or Greek system of treatment; the other for the doctors practising according to the European methods. In every town both the civil and military departments are under the care of both elasses of doctors. The first dispensaries for issuing English medicines were opened in Afghanistan by an Indian hospital assistant, named Dr Daim Khan, and Dr Abdur Rahim Khan. These gentlemen had worked under English doctors, and they entered my service shortly after my accession to the throne. These dispensaries were the only establishments opened by the doctors, hospitals not being started for several years. Government provided food as well as medicines and treatment for the military patients in cantonments.

The first hospital was established in 1894 by my Court doctor, Miss Lillias Hamilton, M.D. This lady was helped by several assistants and a qualified English nurse, named Mrs Daly, whom Miss Hamilton brought with her from England. In addition to opening the first hospital carried on in the English style, Miss Hamilton introduced vaccination, and the taking of vaccine lymph from the calf. This proved a great blessing to the children, of whom large numbers used to die of small-pox, those who recovered being greatly 
disfigured by the pitting following this dreadful disease. Several native hakíms were placed under Miss Hamilton's instruction to study the method of vaccination, and how to obtain the vacine lymph from the calves, and a pamphlet on the subject was compiled by my orders, copies of which were distributed throughout the country to all my people. Hakíms from the most distant parts of my dominions have been invited to learn the practice of this work under the instructions of Miss Hamilton's pupils. Mr Pack, one of my commercial agents, when visiting Kabul, fell seriously ill; he was successfully treated by Miss Hamilton, and as a substantial token of his gratitude, he opened a temporary hospital at Kabul, entirely at his own expense. I earnestly hope that, now the first hospitals are doing so much good, the movement will go on progressing all over the country, until there is plenty of accommodation for the sick to be properly treated under qualified doctors. Miss Hamilton's name may be mentioned here in connection with another service, namely, in that she went to England with my son Nasrullah, as his medical adviser, in 1895. On that occasion she had the honour of being presented to Her Majesty Queen Victoria. ${ }^{1}$

I Afghans, unlike the Indians, are better contented to put themselves under the care of European doctors, rather than go to their own native hakims, partly because the taste of the native drugs is so horrid, and partly because the native treatment is so long and tedious. The patients are forbidden to eat any meat or other strong food; partly, also, because the Afghans are fond of innovations and learning. I have seen people go to Miss Hamilton and ask for some pills, and on being asked what they were suffering from, they would answer: "Oh, I am not ill at present; but I might become so in the future!" They then swallow the pills and walk off. 


\section{Minerals}

There are so many mines in Afghanistan that it ought to be the richest country in the world; but, according to the saying, "that to a person who is not a jeweller, a diamond and a crystal are of equal value," none of the Afghan rulers or people have been able to reap any benefit from these rich mines. During my reign several mines have been opened, including a ruby mine, a lapis lazuli mine, gold and silver, lead, iron, copper, coal, asbestos, stone, and salt mines. I am accumulating various kinds of machinery for the proper and effective working of all these mines. $\mathrm{Mr}$ Middleton, one of the English mining engineers, did good service in the working of the Jellalabad ruby mine and the Ghorband lead mine. I would most strenuously advise my sons and successors not to give the monopoly of their minerals to any foreigners, nor to let their mines be worked by any foreign companies; otherwise they will be immersed in many complications, thereby giving an excuse to foreign nations to interfere in the affairs of the country, for the sake of greed, which is growing unbearable from day to day. I think it would be unwise to give any details, but there are instances where the destruction of a weak nation has been caused by a strong one, under the excuse of fighting for the rights of their subjects, who were interested financially in that weak country. A hint from me on this point should be sufficient to warn my sons and successors never to put themselves into a false position with other nations. 
They should not only refrain from giving any sort of contracts to foreigners in their country, but more especially, they should not allow Europeans to live in the country permanently; the moment that a European servant or workman or teacher has finished the work for which he was engaged, and has taught the native people how to carry the work on without his further instruction, he must be allowed to go to his own land again.

\section{Commissariat Department and Stud Horses}

Though it is possible to hire as many pack-ponies, camels, and other transport animals as may be required at any time, yet, none the less, as a necessary precaution in case of emergeney, and from considerations of economy, I keep 24,000 Government horses for riding and loading purposes, together with a large number of elephants, mules, and camels. The elephants are for the special purpose of dragging the heavy guns, road-engines, and large pieces of machinery that cannot be transported by camels or other animals. I also keep 2000 mares for stud purposes, together with about 80 stud-horses, which are from English studs, some being from the Prince of Wales' stables, others from Arab studs, others from Walar, Turkoman, Indian, and other races of the best horses. To look after the health and condition of all these horses several veterinary surgeons have been placed under the stud groom. There were also some native veterinary surgeons, called paitars, who, however, did not know the 
system of treatment practised in modern European countries. I therefore employed an Englishman, $\mathrm{Mr}$ Clements, in this capacity, who not only looked after the sick horses and the breeding of different kinds, but also taught the work of his profession to twenty other young men of Afghanistan. $\mathrm{Mr}$ Clements also brought a few English sheep with him; and I added to these by buying a large number of Australian sheep for the purpose of increasing the wool trade of Afghanistan, from which trade a large proportion of the income of the country is derived.

\section{Education}

I have opened various schools for the education of members of my family, my personal attendants, and page-boys; for prisoners of war; for the army, and for the children of my officials and other subjects. Besides this, the people themselves have opened voluntary schools for the education of their children everywhere. Every official, no matter what his duties may be, has to go through an examination; even the clergymen and priests, who used to look upon themselves as equal to prophets, cannot be appointed to any post, or admitted to perform the duties of the Church, without first passing an examination, their success in which entitles them to a certificate from the Couneil of Examiners. As I have mentioned under their various headings, education is extended to every profession and department, and I need not repeat them here. My eldest son has learnt 
English, history, geography, mathematics, drawing, surveying, and astronomy.

\section{Commerce and Trade}

In this department, in addition to the old systems carried on in various parts of the country, I have devoted much attention to the improvement of commerce, and I am struggling hard to improve still further the conditions of trade, well knowing that in this lies the greatest source for enriching my country. In the past, as I have before mentioned, hundreds of foreign goods used to be imported into Afghanistan, for which money had to be sent out of the country; now these goods are manufactured at Kabul, and the money can be turned over again and again. Among other articles that were bought from abroad, for example, were vast quantities of salt; I have therefore ordered that no more salt was to be imported, and the people must buy salt from my newly-found mines worked by Afghan people. A large quantity of Astrakhan skins, rubies, gold, lapis lazuli, various kinds of fruits, wool, horses, wood for building purposes, and opium and other drugs, are exported; this also brings money into the country.

In the Agricultural Department vast progress has been made. Before I came to the throne there were scarcely any vegetables; now every kind of fruit and vegetable is grown. I have also introduced the sugar-cane into the provinces of Kandahar and Laghman; orange-trees, bananas, etc., have been imported from India. 
The little trade that did exist in Afghanistan was also carried on by foreigners-Indians, Mahomedans, and Hindus. This impoverished the country, because these foreigners sent the money that they made, over and above what they required for trading purposes, to their own lands. In place of this I have encouraged my own people to carry on trade, by lending them money from the Government Treasury, without charging them any interest on the capital. It must not be forgotten, however, that I am not the man to give my money without calculating the interest: I know that I get on such money double interest-namely, the paying of custom-house duties of $2 \frac{1}{2}$ per cent. on everything imported and exported, and this amounts to more than the usual rate of interest. The same money comes and goes back over and over again in the year, each time paying the duties. The second interest is, that my subjects are occupied in getting a peaceful living, and so they have no time for rebellions and discontent.

I may mention that, notwithstanding my being so busy in the great affairs of the kingdom, I do not neglect the smallest matters, so much so, that I learned how to tune a piano from an Englishman, called Mr Riches. I afterwards taught some of my own people how to tune pianos. I may also say here that I bought a special kind of Sindh fowls and hens, rearing the chickens myself first; I then introduced them to other people.

I introduced hundreds of different stamps and forms of papers for contracts, deeds, promissory notes, marriage settlements, passports, which bring in revenue, 
and were never even heard of before my time in Afghanistan. The richest source of income to the Government, however, is the many manufactures and industries and mines for obtaining minerals that I have set to work and introduced. After military affairs, I devote the greatest part of my daily life to these trade and commercial matters.

Many of my officials who think themselves very wise keep on advising me to introduce railways and telegraphs, saying that it is impossible to get the full benefit of the minerals and other products. But I again advise my sons and successors not to listen to these people. Of course, I know myself that what they say is quite true, but, at the same time, they do not consider that by making the country easily accessible, foreign powers would not find so much difficulty in entering and spreading themselves over our country. The greatest safety of Afghanistan lies in its natural impregnable position. Allah has given us every peak of the mountains for a fortress of nature, and foreigners know that the Afghans, being born warriors, can go on fighting for ever and ever, as long as they can hide themselves behind the stones and do not have to face the enemy on the open field. There is no doubt that the day will come when railways and telegraphs will be most beneficial, and when they will be welcomed in the country, and that day will be when we see that we have a great army, strong enough to fight our neighbours, but until we are strong enough to hold our own, we must not weaken the strength of our hilly country with our own hands. We must not make the mistake once made by the man who killed the goose that laid golden eggs 
every day, thinking that he would get all the eggs at once, which he did not.

\section{Post-Office}

This department was nominally in existence before my accession, but only one road was open for the post from Kabul to Peshawar, and the time taken before letters reached their destination was very long and uncertain. At present proper arrangements are in force, and post-offices are open in every town in my dominions; the delivery is so expeditious, that it takes only thirty-six hours for letters to come from India to Kabul, and the posts run to all the neighbouring countries towards Russia, Persia, China, and India. The system of registering letters and taking the receipt, giving notices and sending parcels, issuing postal orders, etc., is quite complete, and modelled on the Indian post-offices. Sufficient income is derived from the receipts to pay all the expenses. 


\section{CHAPTER IV}

\section{A FEW DETAILS IN MY DAILY LIFE}

From my childhood up to the present day my life is quite a contrast to the habits of living indulged in by nearly all other Asiatic monarchs and chiefs. They live for the most part a life of idleness and luxury, and it is thought by aristocratic people that the prestige of a prince is minimised by his being seen walking on foot or doing anything with his own hands. I myself believe that there is no greater sin than allowing our minds and bodies to be useless and unoccupied in a useful way; it is being ungrateful for the gifts of Providence. The readers of my book can judge for themselves from my history if I have not been, throughout my life, a thorough soldier, and perhaps more hardworking than any common labourer or workman. My way of living and dressing has always been plain and simple and soldier-like. I have always liked to keep myself occupied day and night in working hard at something or other, devoting only a few hours to sleep. As habit is second nature, it has become a habit of mine, that even when I am seriously ill, when I cannot move from my bed, I still keep on working as usual at reading and writing documents and various Govern- 
ment papers; at hearing the applications and complaints of my subjects and giving instructions and judgments. Those who have seen me at such times know how hard I work, and they have often heard me say that if my hands and feet cannot move from my bed, I can still go on moving my tongue to give orders to those about me, and tell them what I wish to be done. It is no trouble to me to work hard; on the contrary, I love it, and I never feel tired, because I am so fond of work and labour. There is no doubt that every person has some sort of ambition, and this is my ambition; all the hard work I do is to complete the administrative work of my kingdom. In the words of the poem :-

"If the beloved should not encourage the lover towards her, the lover will neither have the heart nor the courage to approach her."

This love for work is inspired by God; it is the true ideal and desire of my life to look after the flock of human beings whom God has intrusted to me, His humble slave. Allah says through His Prophet: "When the Almighty desires to do a thing He makes all necessary preparations for it" (Koran). As God wished to relieve Afghanistan from foreign aggression and internal disturbances, $\mathrm{He}$ honoured this, His humble servant, by placing him in this responsible position, and He caused him to become absorbed in thoughts of the welfare of the nation, and inspired him to be devoted to the progress of this people, and to be ready to sacrifice life itself for their welfare and for the true faith of the Holy Prophet MahomedMay God bless him!

The more I see of the people of other nations 
and religions running fast in the pursuit of progress the less I can rest and sleep; the whole day long I keep on thinking how I shall be able to run the race with the swiftest, and at night my dreams are just the same. There is a saying that the cat does not dream about anything but mice; I dream of nothing but the backward condition of my country, and how to defend it, seeing that this poor goat, Afghanistan, is a victim at which a lion from one side and a terrible bear from the other side are staring, and ready to swallow at the first opportunity afforded them. My courtiers know, for example, that years before the question of marking out the boundaries of Afghanistan was mooted, I had dreamed a dream that was published at that time and distributed throughout the whole country. Briefly, the purport of that dream was, that before my death I should finish and complete making a strong wall all round Afghanistan, for its safety and protection. This dream was interpreted by the astronomers to mean that the boundaries of Afghanistan should be so marked out by me that an end would be put to the everlasting forward policy of my neighbours, who used to keep on creeping nearer and nearer every year. Many other dreams of mine, like this, all of which I told to my courtiers, have come true, and they have seen that the boundaries have been marked out, and I am still alive, to the sorrow of those who seem so anxious to put an end to me, as they circulate false reports about my death once a week. I did not think that any man died so many times as they have killed me in their imagination.

VOL. II. 
It is a curious thing that the harder I work the more anxious I am to continue working, instead of getting tired. The appetite grows by what it feeds upon!

To those who would like to know some particulars of my daily life, I would say that I have no fixed time for sleeping nor any definite time for taking my meals; sometimes my meals are kept at the dinnertable in front of me for many hours, whilst I, being absorbed in my thoughts, forget all about them. So deeply do my thoughts take possession of me when I am planning various improvements and considering state affairs, that I do not see any of the people who are in my presence. Many nights I begin reading, and writing answers to letters, and do not raise my head until I see that the night is past and the morning has come. My story is just like the story of a lover, well known in the East, named Majnun, who was so much in love with a lady named Leila, that one day, seeing her dog, he followed the dog, and did not see the mosque nor those who were saying their prayers therein. When he was asked by the chiefs of the mosque to give an explanation, he said that he neither saw the mosque nor those who were saying their prayers therein, because his love to the dog of his lady was so great. They did not love God as much as he loved the dog, because their thoughts were occupied in looking at him and at the dog ; so their prayers were of very small value.

My doctors and hakims tell me that this neverceasing activity is the cause of all my illnesses, that I work too hard, and do not take my meals regularly 
at fixed times. My answer is: "Love and Logic have never agreed together." And as I am a lover of the welfare of my nation, I do not feel my own pains, but the pains and the sufferings and weakness of my people, which I cannot bear for them, and those who have never been in love do not know how sore are the sufferings of lovers.

One of the poets says rightly: "A lover seems to find pleasure in the pursuit of his ambitions, as the dust that arises from the feet of the flock is a salve to the eyes of the wolf pursuing the flock." In my pursuit after the welfare of Afghanistan, the more that I see signs of change and progress, the faster I follow them, as a lover follows the traces of the footmarks of his ideal, which make him more eager to keep on the road. I pray God to help me in carrying out this duty for which $\mathrm{He}$ has selected me from among other men.

On many occasions I get quite discouraged on account of the misbehaviour of my people, who keep on rebelling, quarrelling and intriguing against each other, and making false reports of each other to me. I have then to make enquiries to find out the truth, and this wastes more than half of my valuable time; so that as I try to walk in the steps of progress they keep on pulling me back. I get very weary, and sometimes think that their position is unchangeable and their intrigues incurable, and that it is impossible to raise them to that standard which would make them equal to their neighbours in strength and character. I feel that it would be well for me to retire from this life of everlasting anxiety and struggle, 
and take a quiet, peaceful life somewhere else, leaving my people to fight amongst themselves until they are ruined. But this would be a cowardly action and a refusal to fulfil the duties ordained by the real Almighty Master and Sovereign, for which $\mathrm{He}$ has created me. I believe that a true lover must never turn his face from the difficulties that constantly come in his way, and he must look upon all the naughty and mischievous play of his beloved, and the cruelties shown to him, as very pleasant pains and occupations. The pains of the lover are the luxuries of his love; and the difficulties and anxieties of a reformer only add to his enthusiasm, and spur him on to fresh exertions.

There is no fixed time and no proper programme for me throughout the twenty-four hours of the day and night in which I work; I go on working from morning until evening, and from evening again until morning, like any labourer. I eat when I am hungry; and some days do not remember that I have not eaten my meals-I forget all about it, and ask my courtiers all at once, raising my head from writing: "Did I eat my dinner to-day or not?" In the same way, when I get tired and sleepy, I go to sleep on the same bed which is my chair for work. I do not require any private room or bedroom, neither any room for secrecy or for grand receptions. There are plenty of such rooms in my palaces, but I have no time to spare, even to move from one room to another. Of course I love to go to my harem and spend an evening with my family, and they are equally delighted when I pay these visits, but my time is so full, 
that there is none to spare except occasionally, when I make it!

As I have said there is no fixed time for meals or other personal needs, I may mention that my usual custom is to go to rest about five or six in the morning, rising again about two in the afternoon. The whole time that I am in bed my sleep is disturbed in such a way, that I awake nearly every hour, and keep on thinking about the improvements and anxieties of my country; then I go to sleep again, and so on. I get up between two and three in the afternoon, and the first thing $I$ do is to see the doctors and hakims, who examine me to see if I require any medicine. After this the tailor comes in, bringing with him several plain suits made in the European style. I choose one for that day's use. After I have washed and dressed, my tea-bearer enters carrying tea and a light breakfast. During the whole of the time, from the entrance of the hakims until I have finished breakfast, the Usher, the Secretaries, the Nazir (or Lord of the Seal), and one or two other officials keep on looking at me, and saying in their own minds: "Oh, be quick, and let us each put our work before you!" I do not blame them for this, because the Secretaries have to take answers to all the letters and documents and despatches of the day; the Lord of the Seal has to seal all the orders for the daily expenses of the Government, and to put all the reports of the Intelligence Department which have been received since I went to sleep before me. The Usher has to introduce hundreds of people who have their cases or appeals to be tried by me, or who have to be appointed on certain duties and services, and so on. But no 
sooner do I appear at work after finishing my breakfast than various officials, my sons, and household servants, step in to take instructions for their various duties. Every page-boy, of whom there are hundreds, and men of the Detective Department, walk in with letters in their hands from one or other suffering person, who requires my help and judgment. In this way I am crowded and surrounded by so many who all want to have their business attended to, as well as to show their zeal to me by giving me more work to do. None of my fellow-countrymen have a tenth part so much to do. I keep on working till five or six the next morning, when I resume the same routine, just keeping a few minutes for my meals. Even then, however, my courtiers and officials keep on asking me questions-and, in fact, there is no rest for the wicked!

Since 1891,when I appointed my son Habibullah Khan to hold the public durbars instead of myself, the work which I keep for myself and attend to every day is as follows: Foreign Office; Intelligence Department, political work, Treasury; criminals accused of high treason and other crimes and offences; hearing and deciding the appeals from the Court of my son and all the other inferior courts of the Governors; the work of buying and making all sorts of war materials and things for the workshops; making new courts and amending the law of the land and introducing reforms, or giving instructions to my son and other officials; household affairs of my own family as well as of all the foreign princes and chiefs who are under my protection, my guests, my officials, and page-boys. 
The Courtiers.-The following people are always in attendance upon me from the time that I awake until I go to sleep.

Court Secretaries: Aishak Akasi (Gentleman Usher); Nazir (Lord of the Seal); head of the Intelligence Department; head of the Royal Kitchen, he has the duty of bringing all the petitions before me. There is no more honoured and confidential position than this. The name of the gentleman now holding it is Safar Khan. The British Agent's letters are also forwarded to the Amir through him. One hakím, one doctor, and a surgeon, as well as a dispenser; two or three officers of the body-guard, who, in addition to their being military commanders of the body-guard, are also executioners temporarily during the time they attend the Court. There are a few khansamans (footmen who look after the flowers in the rooms, papers, ink, and pens, etc.); a few peshkhitmats (personal attendants who serve the dinner); mewabardar (fruit-keeper who hands fruits to the officials of the palace); charibardar (tea-bearer, who hands tea to the Amir and courtiers); ab bardar (he hands drinking water); sakab (who brings the water from the spring); ghulam bachaha (page-boys); shatir (the grooms who keep the horses ready saddled and run on foot by the side of the horses to be in readiness to hold them when the riders dismount); the personal chest fund treasurer; storekeeper for the personal arms, gun-room, etc.; chilam bardar (hubble-bubble keeper); a few farashes (those who look after the furniture, carpets, bedding, and other household wants); a few tailors and valets, a librarian, a few door-keepers, and astrologer; arz 
begi (a person who shouts out loudly anything that the complainers have to say); amla bashi (a person who gives notice to those who attend the Court); Mir akhor (the master of the horse).

In addition to these people, the following are always near the durbar room to be ready when required though not in personal attendance: Professional chessplayers and backgammon players; a few personal companions; a reader of books to me at night; a story-teller. Some of the officials who bring reports before me during the day are invited to sit in my society in the evening when they have finished their work. At night a few other nobles and chiefs residing at Kabul come to see me. If I am free, those who are invited to come in to entertain me and have interviews with me are allowed to remain, the rest go away.

The musicians are of several nationalities-Indians, Persians, and Afghans; they also attend the Court at night, being paid for their services, and if I am free, they are allowed to come in and sing and play music. 'Though I am never entirely free, yet the courtiers enjoy the music, and I listen in the intervals. This second group of people is usually employed only for night duty.

There is a third class of personal servants who always keep in the rooms near my sitting-room, or, if I am travelling, in tents near mine, so that they are ready for service when they are called. These are : coachmen for carriages; dhooli bearers; gardeners; barbers and hairdressers; sweepers; storekeepers; draughtsmen ; surveyors ; sappers and miners ; additional staff of medical men; engineering staff; runners on 
foot as well as on horseback for taking messages. There is also a postal department and personal attendants; priests, Imam, or leader of the prayers; schools for page-boys, a band of music, a drum-carrier, umbrella carrier, and flag-bearer.

When I ride out in any direction every one of these personal attendants and servants starts with me, together with cavalry, infantry, and artillery of the body-guard. The riding-horses of my courtiers, several of the officials, page-boys, and other personal servants have gold and silver harness. When the whole cavalcade starts out, it forms a very pretty and brilliant picture. The retinue is arranged as follows, even though the ride is only from one building to another. I ride in the centre, surrounded by my courtiers and officials and special servants, page-boys, etc. These completely surround me on every side, talking to me in turn. The shatirs, or runners, with the horses, chaprassis, walk on foot near my horse or palanquin. This forms the inner circle. The outer

- circle is made up from the second class of personal servants; the tailors, farashes, hubble-bubble carriers, dispensers, etc. The third circle is formed of infantry of the body-guard, who also go before and behind. The fourth circle is formed of cavalry of the body-guard, riding in front and behind. The artillery is arranged according to circumstances, and the direction and time, etc.

Guards.-My own body-guard and those of my sons and wives are of two nationalities, first, of the royal nationality, called Risala-i-shahi Kandahari (Royal Cavalry), of the Kandahar Duranis, the other foot- 
soldiers, which are also of the Durani tribe of Kandahar; the second guard are Risala-i-shahi Kabuli, cavalry body-guard, who are all sons of various chiefs of the hill-tribes of Afghanistan, and also a royal battalion Kabuli, who are also sons of chiefs of Afghanistan. I have added to these Kandahari and Kabuli body-guards a third class, the sons of the Turkoman chiefs, in the cavalry as well as in the infantry of the body-guard. The officers of the cavalry, infantry, and artillery, which form the force of body-guard, are selected chiefs of Afghanistan in whom I have full confidence, and the sons of my brothers and people who have been faithful servants of my father, also those of my followers in the earlier days of my life. The whole force of my body-guard as well as their officers are paid a little higher salary than the other ordinary troops, for the responsibility of being in charge of the lives of the royal family, as well as the royal palaces, treasury, and magazines. This force, together with a small artillery force consisting of Maxim guns, Gardiner guns, and a mountain battery, and one or two other light batteries, are always kept in readiness to start with me in any direction at any moment that I wish to march. I am always ready as a soldier on the march to a battle, in such a manner that I could start without any delay in case of emergency. The pockets of my coats and trousers are always filled with loaded revolvers, and one or two loaves of bread for one day's food; this bread is changed every day. Several guns and swords are always lying by the side of my bed or the chair on which 
I am seated, within reach of my hand, and saddled horses are always kept ready in front of my office, not only for myself, but for all my courtiers and personal attendants, at the door of my durbar room. I have also ordered that a considerable number of gold coins should be sewn into the saddles of my horses when required for a journey, and on both sides of the saddles are two revolvers. I think it is necessary in such a war-like country that the Sovereign, and especially a Sovereign who is a soldier himself, should always be as prepared for emergencies as a soldier on the field of battle. Though my country is perhaps more peaceful and safe now than many other countries, still one can never be too cautious and too well prepared.

All my attendants go to sleep when I do, except the following, who keep awake in turn: The guards with their officers; the tea-bearer; the water-bearer; the dispenser; the hubble-bubble bearer; the valet and tailor. ${ }^{1}$

My page-boys consist of the sons of the members of the royal family, sons of the nobility and chiefs, sons of the officials of my Court; in addition to these are my slave-boys, consisting of Kafiri, Shignani, Chitrali, Badakshi, Hazara, and various other tribes. In fact, these boys are more under my tutorship and training than any other of my servants. They are dressed like princes in velvets and most valuable uniforms; they have magnificent horses to ride; they have servants and personal attendants, pocket

${ }^{1} \mathrm{He}$ is always at hand to do any repairs or take instructions when the Amir thinks of it. 
money in addition to the dress, food, horses, houses, and servants from Government, and when they grow up, owing to their having been trained by me, they are appointed to the highest posts in the kingdom. For instance, Faramurz Khan, a Chitrali slave, is my most trusted Commander-in-Chief at Herat. Nazir Mahomed Safar Khan, another Chitrali slave, is the most trusted official of my Court; he keeps my seal in his hands to put to any document, and to my food and diet-in short, he has the full confidence of my life as well as of my kingdom in his hands. Parwana Khan, the late Deputy Commander-inChief, and Jan Mahomed Khan, the late Lord of the Treasury, two of the highest officials in the kingdom, in their lifetime were both of them my slaves.

To tell you the truth, the word slave is only a name; the real sense of the word slave in Afghanistan during my reign is this: they are more trusted and honoured than any other officials of the kingdom. When they are quite grown up I arrange their marriages with the daughters of the nobility and highly respectable families. I give them houses and furniture and all requirements of life better than those possessed by princes of the royal family. Their wives have separate allowances for their pocket money as well as Government personal attendants. In this way, I have cleared out and abolished the cruel system of slavery. The word slave is merely a remnant of the old times, otherwise there is no such thing as a slave in Afghanistan. The buying of slaves is forbidden by law, and male or female slaves in various families, who were always slaves in the old times, are treated as 
members of the family by their masters. The offspring of slaves are called Khanah Zad (born in the family), and are just as kindly treated, and loved with the same affection as the other children of the heads of the family. If a person kills a slave, as they used to do in ancient times, the punishment is death. If a slave is badly treated, and the cruelty is proved, the slave has his liberty by my orders, because God has created all human beings children of one parent and entitled to equal rights. There is no reason why one should be a tyrant and the other the victim of his tyranny.

Usually the male and female slaves of Afghanistan are either the children of prisoners of war or of parents who have been killed in war, and they have no one to give them a living. The rich families and nobles give them the same privileges as their own children enjoy, and, like the royal page-boys, when they grow up they are well married, and get better positions than many poor people, through the influence of their patrons. They thus rise to very high positions, according to their education and merits and manners acquired by association with well-brought-up children.

When 1 conquered the country of Kafiristan in 1896 I ordered that no prisoner of war should be sold as a slave, and also that no one should be allowed to marry a Kafir woman against her will. I compensated by presents of money those people who had captured prisoners as their booty and thus were entitled to keep their gains of the victory, and I then released the prisoners and set them free.

Food.-In my belief we eat to live, though too many Eastern chiefs act as if they believed that they live 
to eat. I have strictly forbidden, under a penalty of severe punishment, the drinking of wine. I do not drink wine myself, nor do I allow any of my Muslim courtiers and attendants to drink wine, except in case of illness, when prescribed by a doctor. Ready cooked food is given from the Government kitehens to all the above-mentioned personal attendants. My wives and grandsons, together with their personal attendants, also get cooked food from the same source. Once a week all the military and civil officials attend a public levee, held by my son, Habibullah Khan, and lunch with him, in the grand durbar in the building of Salam Khana (a large audience hall for public ceremonies and functions; it holds about 1500 people). I held these levees myself until 1891.

The expenses for food for the royal kitchen are paid out of the State Treasury and in all the other towns of Afghanistan; also, the Governors of the provinces and towns give dinners to all the civil and military officers and chiefs who live there at the Government expense, as my deputies. This system of hospitality has always existed in Afghanistan, and though it is very expensive it must always be kept up.

The food cooked for myself and my officials, as well as for the members of my family, consists of Kabul cooking, namely Pillao (rice and meat cooked together), roast meat and various other dishes, Uzbegi or the food of the Turkomans, Indian dishes, European dishes of all kinds, so that every person may select the dishes he likes best, as people of so many nationalities are in my service.

Meals are served in the following manner. The 


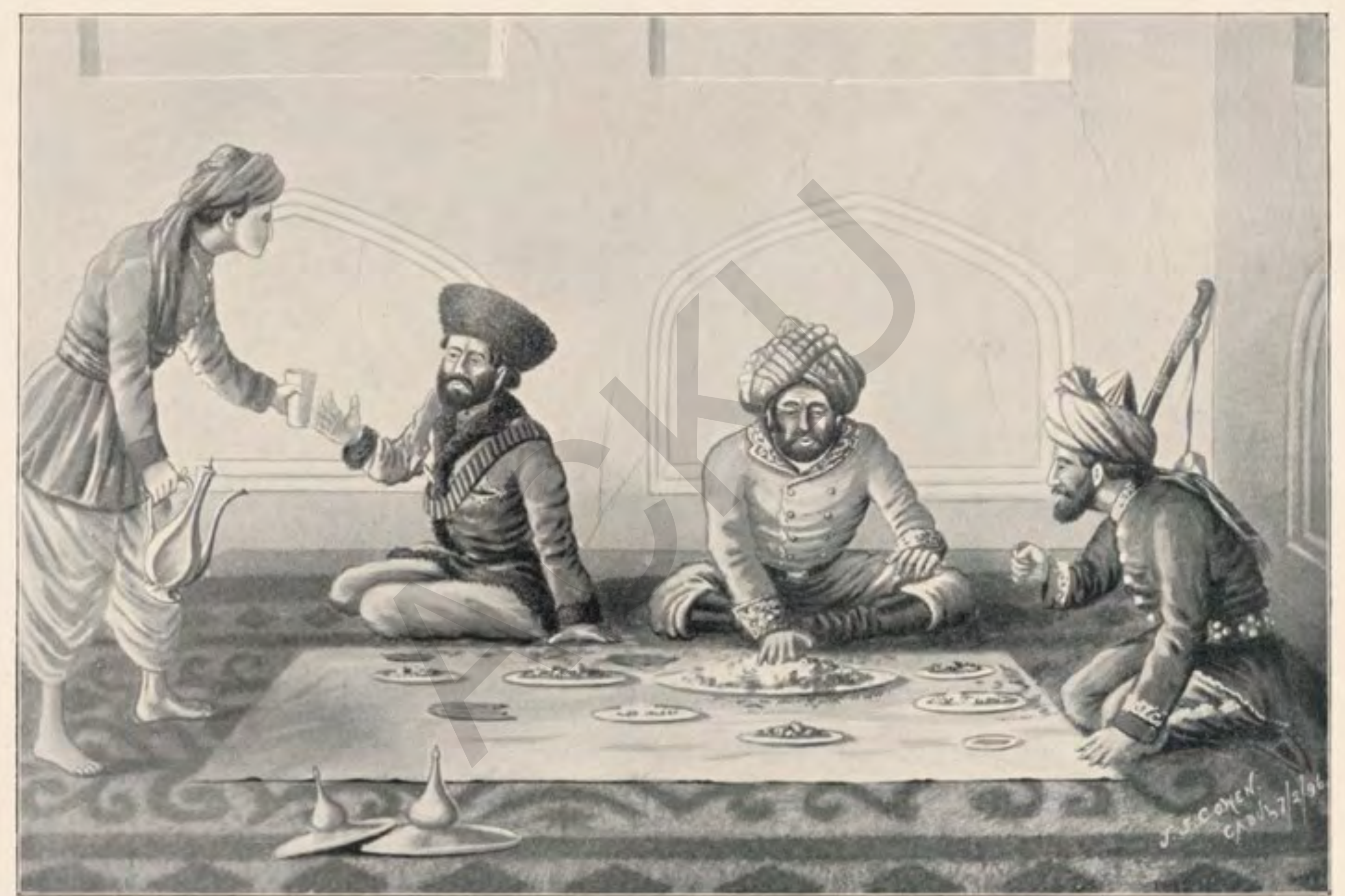



first thing on awaking is a small breakfast, consisting of tea, fruits, biscuits, cakes, roast wheat and butter; then lunch between two and three in the afternoon; again fruits and tea near evening, and dinner beween ten and twelve at night; though I myself only eat one full meal during the day, with occasional refreshments. My courtiers and other personal attendants, as well as my sons and my wives and their staffs of attendants, eat two full meals, with fruits and refreshments between times.

Such officials or servants as are allowed to sit and dine at my table and in the presence of myself and of my wives, sons, and daughters, do so; while subordinates and menials have their food in various other rooms, according to their position. Others, again, have rations of food, fruits, and tea given them to eat in their own houses. The food that is left is divided among the farashes and peshkhitmats.

The way the dinner is served is this: the dishes are placed upon the table, which is covered by a tablecloth; the table is large enough for all the invited guests to sit down at once. After this the peshkhitmats bring hot water to pour over the hands of the courtiers and officials, and when their hands are washed they sit down to the table, the table servants waiting upon them. When dinner is finished, servants again bring hot water, the guests wash their hands once more, and fruits are then handed round. They are thus saved the trouble of going out of the room to wash their hands.

In my sitting-rooms and bedrooms, as well as in those of my wives, sons, and daughters, all sorts of 
beautiful flowers, plants, pictures, and pianos and other musical instruments are placed, together with choice pieces of china and other ornaments, Persian and Herat carpets, nightingales and other singing birds. Beautiful and valuable furniture and everything that I can think of, to add to the pleasure of those who associate with me, are to be found in my palaces. If any foreigners or Europeans are present at the time for meals, they are welcomed at our table, and dine with us as our guests, if they are Muslims; but if not, they dine in another room, or at a separate table. I have frequently heard Europeans say to me that they enjoy food cooked in the native method better than the European dishes. I cannot see what is in their heart, but $\mathrm{I}$ am very pleased if they really mean it, and do not say it merely out of compliment to me, their host; but as I generally see that they eat far more of our Afghan cookery than of the European dishes, I think it is clear that they speak the truth, because no man would eat very much of anything that he disliked just to pay a compliment.

For my wives, my daughters, my sons and their wives, my grandehildren and their servants, in addition to their food, clothing, horses, and houses, there is a special monthly cash allowance granted by the Government, in accordance with their positions and requirements. Both my eldest sons, Habibullah and Nasrullah, are paid 20,000 rupees a month each, for their pocket expenses, and their wives and other personal attendants are likewise paid separately. My wives (two of whom are the daughters respectively of Mir Hakim Khan and Mir Jahandar Shah, the latter 
the mother of Habibullah and Nasrullah); the mother of Mahomed Omar Jan; the mother of Aminullah Jan; the mother of Ghulam Ali; the mother of the late Hafizullah and Asatullah; the mother of Fatima Jan, my daughter, have all their separate allowances paid monthly, for their pocket money, from 3000 to 8000 rupees Kabuli: their dresses are not to be paid for out of this money, neither are their houses, food, or other requirements. Their dresses are many, and of various fashions, some being in the European, others in the Oriental, style.

My youngest sons and granddaughters have also, in addition to their food and clothing, etc., a monthly allowance for pocket money.

On the great festivals of Id Barat and New Year's Day, my wives and children get their dresses and cash and jewellery as presents, just as is the European custom to give presents at Christmas. All the children of my courtiers, officials, and servants also receive presents from me on these days.

My sons, who work hard all day long, generally spend the evenings in their harems with their wives and children. In the early days of my reign, I used to pay visits to my barem about twice a week, but as I grew more and more preoccupied with affairs of business and state, these visits were cut down to one or two a month; but now my time is so full, that I only pay two or three visits in the year to my wives and family. The rest of the year I occupy the same rooms in which I work, both day and night. My wives, however, come and pay regular visits to me ten or twelve times in the year for a few hours at a time.

vol. II. 
God has created me for His service, to care for the nation $\mathrm{He}$ has intrusted to my care, and not to spend my time in personal enjoyments and self-indulgence. My greatest happiness is always to continue working in His service.

My two sons, Habibullah Khan and Nasrullah, come to see me twice or at least once every day to take their instructions for arranging and doing their daily work. My youngest sons and grandsons visit me about twice a week for a few minutes, and as I am always busy, they sit down and play for a short time, or sometimes they wrestle with each other and sometimes with me, and then they are sent back to their own houses.

My children and grandehildren are brought up in this way. From the day of their birth nurses are appointed to give them milk, and to take them once or twice daily into the presence of their mothers, and occasionally to bring them to me, and from the very first year of their birth a chaplain, tutor, and guardian, servants, body-guard, and houses with small gardens, are appointed for their separate use. These houses are away from those of their mothers and my own, so that the children can always be under the care and tuition of their nurses and tutors and guardians. These guardians are always old, experienced, retired officials of the Government, and the children, instead of getting stupid and naughty under the spoiling of their mothers, are properly and carefully trained by those who are responsible to me. The children thus grow up good, well-trained, gentlemanly boys. I always keep a careful watch, and take the keenest 
interest in their training, watching with an examining eye their manners, ways of life, and education.

When they arrive at full age, they marry and become masters of their own homes, then only paying visits to me and their mothers at certain hours of the day, when their daily work is completed. They are also instructed to call on their older relatives and look after them, and see they do not want anything. They are ordered to keep up the habit of reading and going out for fresh air and exercise, and make up shooting parties, so that they may not grow lazy or fall into a state of ill-health from lack of exercise and work.

My wives have permission to go out for horse-riding and driving; their palaces are fine modern buildings with gardens, situated outside the eity; they and my sons' wives have their body-guard to escort them when riding or driving out. No duties or services are imposed upon my wives, except looking after the arrangements of the household, but my sons, like myself, must serve our country. The duties placed upon my sons at the present time are as follows:

Habibullah Khan, my eldest son, has the same duties to perform as I myself or other Amirs of Afghanistan have had to do, with the exception of some new offices, such as the Foreign Office, which I have kept for myself. This is the daily programme of Habibullah's work: he attends his durbar about ten in the morning, dismissing it at four or five in the afternoon. On Mondays and Thursdays the Secretaries of his durbar read to him all the applications and letters which come by the post or by runners from Herat, Kandahar, Balkh, Ghazni, Jellalabad, India, and 
other parts of my dominions. Orders on the Treasury for the payment of the daily expenses of various departments, the reports from the Governors and military and civil officers, and heads of manufactories, magazines and public works, revenue offices, etc., are made out and given to the respective officials. They also get his signature and seal upon the answers, papers, etc., and despatch them by the post. After this work is finished he is engaged upon anything that comes to hand until he goes to rest, reserving a short time for riding and fresh air. He attends my Court before he goes to bed for a few minutes, and, if necessary, also when I awake in the morning. On Tuesdays he holds the military levée, and all the military officers lunch with him. He also engages new recruits for the army, and attends to all military affairs, gives decisions in cases of military offences, disputes, etc. On Wednesdays he holds a levée for the civil officers present at Kabul, when he decides any civil cases brought up to him. On Saturdays he tries and sentences prisoners and releases others; he listens to eriminal eases brought before him by the Kotwali and from other sources, appeals, etc. On Sunday he inspects all the manufactories and industries and the various magazines in Kabul, listens to the requests of the workmen, and gives them leave, promotion, pensions, etc., according to their merits. Friday is his day of rest, to be spent with me or in hunting and shooting; he also attends the weekly services at the mosque; pays ealls on his mothers ${ }^{1}$ and relatives.

${ }^{1}$ In Afghanistan a son regards all his father's wives in the light of mothers, as in England stepmothers are regarded. 
The procedure for trials in all the Courts of my kingdom is very easy and simple; every individual can see me or any of the responsible heads of my Government personally, and state his own case, without intercession or recommendation from any one; an impartial judgment is then given by me or by my son, according to the evidence and proofs of the case. If a person does not like to state his case in public, he can send it up in writing. There is much time wasted in reading these long, tedious applications of the people, and very little sense in them; but the people are too lazy to move their tongues, though they will waste time in writing yarns and yarns. I therefore ordered that everybody, excepting Court officials, who wished to make a complaint in writing, should buy a proper stamped form, valued at three rupees, and state his application thereon. This put a stop to the unnecessary trouble, and the Court Secretaries make short abstracts of these letters and answers. Complainants, bringing their grievances before my son, stand one by one behind a wooden fence, which permits of only one person walking up the aisle at a time; they are ushered in by the proper attendant appointed for the purpose. If, however, there are any old women or old men, or those who are too weak or nervous, or who from any other cause cannot explain themselves properly, these usbers speak loudly in the presence of the complainants to my son, who thereupon makes enquiries and gives the final judgment. There is no difference in the laws for rich men and beggars in our Courts; if a beggar and a prince have grievances against each other, they are both considered equal; they both stand 
shoulder by shoulder in the presence of me and my son until the case is tried. There is no nonsense of the old times of Afghanistan, when the strong, by using the influence of his friends, had certain privileges and advantages over the weak.

In complicated and tedious cases which require looking through various counts or protracted evidences of proof, my son Habibullah first sends the cases to the Ecelesiastical, Criminal, Commercial, or Revenue office, as the case may demand, to make the preliminary enquiries; the case is then forwarded to me in the form of a short outline for the final judgment.

Habibullah's younger brother, Nasrullah, has been appointed the head of the Accountant's office (Daftar Hisab Giri), and after the accountants have decided that the accounts of the parties have been settled impartially and rightly, a counsel of arbitration affixes his seal, when he has approved all the details. The document is then signed and sealed by Nasrullah, and this stops all further dispute. But if the parties do not agree with the accounts as settled by the accountants, the counsel of the arbitration, in the presence of Nasrullah, re-examines the case and gives the final decision. In such cases as are beyond the jurisdiction, Nasrullah sends them to Habibullah or to me, as the case may be.

My other sons are not old enough yet to be appointed for any services.

Since the appointment in 1891 of Habibullah to the administration of all the above duties, there is no fixed day for me to do any kind of work; but from the time that I awake to the time that I go to 
bed, I do my work and duties with so much ardour that whatever comes first is done then and there.

There is a leader of the prayers (Imam) appointed for the courtiers, who gives the prayers five times a day; and the Muhtasib (directors) are appointed throughout the whole country, who first advise the people to attend the mosque five times a day for their prayers and to keep fasts in the month of Ramadan, and then, if people will not listen to their advice, they administer a certain number of lashes, because a nation which is not religious becomes demoralised, and falls into ruin and decay, and misbehaviour makes people unhappy in this world and the next.

In my country the people who are believers in other religions are tolerated and treated without prejudice-more even than the people of my own religion; they are appointed to the highest posts under the Government, which is quite opposed to the law that people who do not belong to the Established Church of England are deprived of the right to hold certain offices. For instance, I am a Sunni Muslim, yet some of the highest offices are filled by Hindus and Shias.

Any person can put his claims before me in the following way: he comes to the door and reports that he wishes to see me, and is invited to come in and tell me himself, or to put his grievance in writing and give it to the Nazir, his assistant, or to one of my Court Secretaries, or even into the Post-office. He must write on the cover- "Not to be opened by any one except the Amir." I open such letters myself, 
and, if necessary, I also write the answer with my own hand, and forward it to the petitioner by the same means by which it eame to me. If he do not succeed in getting his letter put before me from any of these sources, there are my spies and detectives, both public and private, who are severely punished if the case is not reported to me. In fact, it is the belief in Afghanistan that every individual possesses a signature of mine, and in every house there is a detective. This is an exaggeration, I think!

All my residential palaces are built on sites that command a beautiful view, and in a bright, breezy place. They are surrounded by gardens and flowers, and they are built in such a style that it is possible in the same building to have warm rooms for winter use, and open verandahs with large windows for the summer. The rooms are so arranged that the spring blossoms may be watched as they break from the trees, and the gorgeous yellow hues of the autumn, and the dazzling falls of the winter snow and the moonlight nights are enjoyed by all the inmates of my palaces who take the trouble to sit at these windows. As a rule, I spend my summer, spring, and autumn outside the town, living for weeks in tents pitched in these positions where all the beautiful blossoms can be seen, glowing sunsets, and the yellow autumn tints. I have always loved beautiful scenery, flowers, green grass, music, pictures, and every kind of natural beauties.

My daily uniforms are very simple, made in the European style; on great occasions, however, I wear military or diplomatic uniforms. At night, or in my 
leisure moments, I wear loose robes of Chinese and Japanese silk, made in the Arab or Turkoman or Mongolian fashion. I also wear a small cap with a very small silk or muslin turban. This last loose dress is very easy to put on and off; it is therefore comfortable, especially when I am ill and suffering pain.

Wherever I happen to be, travelling or at rest, there is always a school arranged for my page-boys. Here they learn their religious duties, history, geography, mathematies, and modern languages, aiming and shooting with rifles. Whilst one portion of them is in attendance upon me, the others are practising their studies, and when at last they finish their education and grow up, they are given their posts.

In the military service there is one battalion called Khana abadi (the foundation of the home) made up of small boys, sons of the various military officers and chiefs of the country; they are drilled and trained in military tactics, and afterwards appointed to various regiments and battalions.

I myself and some of my officials smoke cigarettes, others smoking the hubble-bubble.

My entertainments are very simple; throughout the whole of the time I am working, at intervals of a few minutes after I have finished answering a letter or a piece of work, I stop for a moment and chat and talk with my officials and courtiers. The professional chess players and backgammon players play their games before me in the evenings; I watch them sometimes, and sometimes I will play myself, though this is not often. Musicians keep on playing and singing for the 
pleasure of those who are present, and sometimes I also steal a minute or two to listen to them. I love music, and the best pianos, guitars, violins, bagpipes, and other musical instruments are always to be found in my palaces. I know music myself well, and can play the violin and rubab. ${ }^{1}$ It must therefore be a luxury and pleasure for my officials to be in my presence to enjoy all the various pleasures that I provide for them, and those who serve me sincerely and honestly are treated as my personal friends, sometimes being playfully teased by me, and sometimes teasing and joking with me; there is always laughing and joking going on, but with those who are insincere and hypocritical I am very severe and harsh :-

"To treat those kindly who disturb the peace, Is being an enemy to those who love peace." - SADI.

I do not go to sleep directly I lie down in bed, but the person who is specially appointed as my reader, sits down beside my bed, and reads to me from some book, as, for instance, histories of different countries and peoples; books on geography, biographies of great kings and reformers, and political works. I listen to this reading until I go to sleep, when a story-teller takes his place, repeating his narratives until I awake in the morning. This is very soothing, as the constant murmur of the story-teller's voice lulls my tired nerves and brain.

I myself have written several books, which have been printed at the Kabul Press. There are certain ad-

1 A musical instrument, something like a banjo. 
vantages in the custom of reading books aloud to me, viz., that in my lifetime thousands of books have been read to me, and this means that I have had a daily lesson in progress and learning. One also remembers better what is told in the form of a story when read aloud. The stories are mostly full of exaggeration and superstitions, yet even in these I learn much of the old habits of thought and ideas of ancient peoples, and I think of the progress that the world has made since those old times. There is another advantage in sleeping through the droning noise of the story-teller's recitations, namely, that one gets accustomed to noise, and I can sleep soundly on the battle-field and under similar circumstances.

I can speak and read the following languages: Pushto, the language of the old Afghan tribes; Persian, the language of the Court and of literature-this is also the official language; Turki, the language of my Turkoman subjects; Russian, Arabic, and Hindustani. The last-named two tongues I do not know thoroughly, but I understand them. I like to know something about all subjects, and never neglect an opportunity of acquiring fresh knowledge. When, therefore, any foreigners or my own countrymen come into my presence, I ask them all kinds of questions, especially upon those subjects on which I know they are qualified to speak. In this way I learn something from every body. 


\section{Festivals and Holidays.}

In Afghanistan, there are five days set apart for festivals; these are as follows : two Id festivals-one is the Id after the Month of Fasting; the other is fixed two months and ten days after the first-named feastday. This is ealled the Id of Pilgrimage to Mecca. These two festivals being fixed by the moon, keep on changing in the different seasons. The third festival, that of Barat, is also fixed by the lunar month, fortyfive days before the Id of Fasts. The fourth feast is the Nauroz, or New Year's festival, falling on the 21st of March every year. On all these occasions I give rewards and robes of honour to some of my officials and servants, as well as to my family and relatives. On the days of Id also the merchants bring presents to me.

The day of Nauroz is devoted to a general inspection by me of various goods and war materials and weapons, ammunition, etc., which have been made throughout the whole year in my Kabul manufactories and workshops, excepting those placed in the stores. The workmen who made these things are either rewarded or fined, according to the quality of the articles made by them. Instructions are then given for the coming year, and faults pointed out that more care may be taken in the future. Such guns, rifles, cartridges, etc., as pass my inspection are tested by being fired, and finally are stored in the Government arsenal and magazines; those found defective being returned to the workshops to be set right. 
The fifth festival is in remembrance of the title bestowed upon me by my nation, namely, "The Light of the Nation and Religion." This title was offered me on the day of the Id of Pilgrimage, 25th May 1896, but as the confirmation of this title from all the provinces and other towns of Afghanistan, other than Kabul, reached me in the month of August, corresponding to the 24th of the solar month, called Asad, which does not change like lunar months, this festival and the illuminations are always held on the 24th of Asad.

The orders and decorations bestowed by my Government on various officials are the following: Hurmat (Reputation or Personal Distinction); Izzat (Honour or Glory); Shujat (Bravery); Amanat (Confidence or Honesty); Sadakat (Sincerity); Khalusyad (Faithfulness); Khirkhewah Islam (Defender of the Faith, or Well-Wisher of the Faith). There is only one case of this last-mentioned distinetion being given, and that is the one granted to Mir Munshi Sultan Mahomed Khan in 1893, the day when Sir Mortimer Durand's Treaty with my Government was sealed and signed. All these orders are made of gold, some of them being further enriched by precious stones. There are also silver medals, of which there are a large number; these are given on the occasions of great victories on the battle-field to brave military men who distinguish themselves. The name of the place where such victories are obtained is always engraved on the silver medals.

Though I do not believe that our Holy Prophet, may God bless him! ever ordered that wives should be shut up in their houses,- and this matter has indeed been always disputed,-yet it has always been the custom 
among the nobility and richer classes of people, from ancient days, to keep their wives in the harems (harem means sacred); places set apart in houses or palaces for these ladies to live in. For these ladies who do not leave their houses it is necessary that some means of communication with the outer world should be arranged. In every one of my harems, therefore, are several page-boys and some women servants. Over these, for all the harems together, there is a Sirdar, who is a young lady, but dressed like a man. All these people take and bring letters and messages. I have abolished the old system of eunuchs, which class of men used to be employed in the harems for this purpose. In addition to these people, my wives have their own personal attendants and departments, such as Ushers, Door-keepers, Treasurers, Masters of the Horse, Masters of the Robes, etc. My wives travel about when they wish to do so, driving in their carriages or riding on horse-back, always being covered by veils to hide their faces. 


\section{CHAPTER V}

\section{ANGLO-AFGHAN RELATIONS}

"Be faithful and true to your oaths and promises."-Koran.

"All the happiness in the world consists in these two words: kindness to friends and politeness to enemies,"-SADI.

THovgr the heading of this chapter might seem to require that I should mention all the communications, intercourse, and relations between Great Britain and Afghanistan from the very beginning, as well as their boundaries, which keep on changing on various occasions : and should also give some expression of my opinion as to the future relations between these two nations, I shall leave these points to be separately discussed in two separate chapters, under the headings of "Boundaries of Afghanistan," and "The Future Policy." In this chapter I will confine myself to the most conspicuous and important points that have arisen between my Government and that of Great Britain during my reign, and I will try to put it as briefly as possible; for to say all that is in my mind would be unwise, even were it possible, to put it in writing.

I will not attempt to settle and discuss that one point upon which, from the very first day I ascended 
the throne until the present time, there has been so much criticism and conflict of opinion between the British and Afghan public: I leave these two peoples to decide and judge matters for themselves, and their disputes do not concern me. The point under dispute is this. Many of the English newspapers and British public say:- "We granted the throne of Kabul to Amir Abdur Rahman Khan, and he is our paid servant." The Afghans in reply say:- "Did the English invite Amir Abdur Rahman Khan to come from Russia and accept the throne of Kabul? No!" "Did the British Government release him from the Russian guardianship, or did they request Russia to let him come to try his claims for the throne? No!" "Did the British Government inform Amir Abdur Rahman Khan in Russia that he could press his claim to the throne if he wanted, as they were looking for a claimant to the throne? No!" "Did the English give him any pecuniary or any other kind of help for his travelling expenses from Russia to Kabul, or any other assistance in any shape or form before his accession? No!"

The Afghans continue: "A few months after his arrival on the Afghan borders and his entrance into the country, Mir Sultan Murad Beg, and other Mirs of Kataghan and Turkestan detained him, and would not let him go to Kabul, because the English officials who were at Kabul, thinking that Abdur Rahman Khan was sent by Russia, or had come by the permission of Russia, did not wish him to come to Kabul. They were offering the Kabul throne to Musa Jan and other candidates, as they could not keep the 
country themselves, because the people were brave warriors, and the country was considered neutral between England and Russia. But," the Afghans go on to say, "having seen that by the help of Allah and the force of his own strong hands, Abdur Rahman Khan broke down all these obstacles that were placed in his way, all the Mirs (rulers) submitted to his rule. He conquered the whole of Turkestan : he entered Kunduz, and thousands of Ghazis, together with all the army, now joined him, and Musa Jan did not accept the throne from the hands of the English. Neither did anybody else. And throughout the whole of the country arose a warlike spirit, expressed by gatherings of the Ghazis, who grew stronger and stronger in their anti-English feeling. Ayub was leaving Herat to attack the English forces at Kandahar at that time, and the English were obliged to open their communications with Amir Abdur Rahman Khan, and make friends with him, so that they could quit the country with safety and credit. It was we, the nation of Afghanistan, who invited Abdur Rahman Khan to come from Russia, by sending our deputations and representatives. He acceded to our request to be our ruler, and left Russia. If any one takes the trouble to read the communications which took place between Sir Lepel Griffin and Abdur Rahman Khan, they will easily see for themselves that the Amir wrote in plain words that he would not, and could not, accept the throne except by the consent and from the hands of his own Afghan people. We had announced him King at Charikar before he entered Kabul, and before Sir Lepel Griffin's visit voL. II. 
to the Amir. This announcement of ours was, of course, confirmed by Sir Lepel Griffin and the British officials at Kabul, and they parted on friendly terms with him. He proved himself to be so true and faithful in his words, that the English army, which was in a more eritical condition than in 1840, were enabled to leave the country in safety at the time when the news of the disaster of the English army at Kandahar reached them. The monthly subsidy which the English Government pays him, of course the Indian Government would not pay if it were not to their own advantage and interest. The Amir spends all this money, and more even, in buying arms and war materials from England, to be used for the protection of the Indian frontier line. The Amir has refrained from claiming certain places, as well as from communicating with various foreign powers, without the knowledge of the Indian Government, and until he has consulted with them. $\mathrm{He}$ has also refrained from joining with any of the enemies of India, feeling himself bound by every sacred bond of faith and by his promise; and if England did not consider his friendship worth having, they would not pay him this subsidy. Why did they not pay other rulers, princes, and Nawabs and Rajahs of India, some of whom, as the Nizam of Hyderabad, have greater dominions than the Amir's? Besides, this subsidy was paid to all the Afghan rulers, from the time of the Amir's grandfather, because, by ensuring the strength and safety of Afghanistan, the safety of India is also ensured from foreign aggression."

I do not concern myself with these utterances 
of the common people: I leave criticisms to the people themselves to decide according to their judgment. It is to the interest of England and Afghanistan to be united in the bonds of friendship, and in so doing they will be friends to their own separate interests at the same time. I pray and strictly advise my sons and successors, and those of Her Majesty the Queen, always to continue to cement this friendship on foundations more and more solid; as the safety of India and Afghanistan are bound up together - their strength lies in union - their weakness in disunion.

I cannot pass away from this subject without trying to remove any impression that there may be in people's minds that Sir Lepel Griffin and the British officials at Kabul only confirmed the announcement of my Amirship made by my people; they did the greatest service to both the British Empire and to the Afghan nation, by bringing their communications to a close in a shrewd and statesman-like manner. I myself believe that Sir Lepel Griffin, in his communications with me and with the Afghans, by bringing this matter to a condition of such friendly union, played his cards very wisely in the interests of his Government, and that he has not been sufficiently requited for his services. I think that he deserves the title of "Lord of Kabul," just as much as Roberts did that of "Lord of Kandahar."

Ali, the fourth apostle of Mahomed, says: "Do not seek who did or said, but appreciate what he did or said." It is of no consequence upon which side the obligations are stronger; the one main point to re- 
member is that the interests of the two nations are identical.

Considering the above point carefully, I began from the first day of my reign to cement this friendship; I am thankful to the Marquis of Ripon, who greatly encouraged me by giving me every assurance of friendship during his Viceroyalty. My first envoy, under his administration, was General Amir Mahomed Khan, who had been my most confidential servant from my childhood; he was a most clever and experienced statesman. A Mahomedan envoy was also appointed to my Court, as a further proof of the friendly disposition of the Indian Government towards me. The Marquis of Ripon wrote to me on the 16th June 1883, fixing twelve lakhs of rupees as the annual subsidy for my Government, for fortifications on its border line, and for strengthening its army.

It would not be out of place to say a word or two on the character of this most liberal-minded Viceroy, who had no prejudices against caste, colour, or creed, believing that it matters very little what colour people are when they shall stand before the Almighty Judge to answer for their doings. He followed this principle throughout, that we are all equal in the eyes of God, and therefore there was no reason why there should not be equal justice meted out to all alike in the courts of His deputies, the sovereigns of this earth. He tried to give the Indian subjects of Her Majesty the Queen the same rights enjoyed by her white-skinned subjects. This displeased some of the said white-skinned ones, but this broadness of policy left an impression on the people, and awoke in their minds and hearts an intense 
devotion and affection towards him. Throughout the whole period of his Viceroyalty, the relations between myself and the Marquis of Ripon were of the most friendly and cordial nature.

There is a saying that that which takes years to spread requires years to fold up again. Therefore it was not possible that the hostile feelings, the enmities, the hatred, the mistrust and suspicion which had existed between the English and Afghans for about fifty years past-which had caused friends and kinsmen of the two nations to fight against each other and to be killed by their hands-could be forgotten all at once. Both nations had written narratives and books, calling each other treacherous, unreliable, and breakers of their oaths. To put all these feelings and differences of opinion right, and to wash from the minds of the two nations all remembrance of the past, and to enable them to trust each other fully at a time when all friendly assurances were looked upon with suspicion, was no easy task, if not altogether impossible. There were many reasons against this friendship; it was very difficult to make the friendly relations as strong as was desirable. The Indian Government had neither the authority to give me so much help, or to promise me so much help as was necessary; neither have they trusted my sincerity and truth and friendship sufficiently to desire to do so. On my part, I was unable to show my friendship publicly to the extent that was necessary: because my people were ignorant and fanatical. If I showed any inclination towards the English, my people would call me an infidel for joining hands with infidels, and they would proclaim a re- 
ligious holy war against me. I knew that so long as I did not clear out of my country these fanatics and rebels, I could neither show my friendship fully, nor carry it out to its fullest extent. I was not a fool like Amir Yakub, who before the consent of his people had been obtained, and before making himself strong enough to protect Sir Louis Cavagnari, accepted his Mission at Kabul, in order to show his friendship. But it was more than he could carry out, the result being that Cavagnari was killed, and he himself dethroned and taken prisoner to India, and hundreds of thousands of people were killed.

The Indian Government had made a treaty with me not to interfere in the internal difficulties of Afghanistan, and therefore, even if the people of Afghanistan should have announced a holy war against me on account of my friendship with India, I had no pledge from the Indian Government of India to help me in my internal and home troubles.

Besides this, I did not want to utter such flattering words to the British Government for the sake of this friendship as would place me in the list of flatterers and cowards. I have shown during my reign that self-respecting pride which is the hereditary characteristic of my nation; I have never parted with it, even at a time of much difficulty and emergency.

I felt, however, that not knowing each other fully is a cause of misunderstanding, and a chronic misunderstanding results in quarrelling, and chronic quarrelling results in wars and fighting, which means ruin. For this reason I have been very anxious, and I am still anxious, that the English and Afghans 
should see more of each other, thereby coming into closer contact and more intimate relations; for, the more they trust and place confidence in each other, the better it will be for both nations.

I tried to attain the above-mentioned object as soon as possible, but the Indian Government were full of scruples, such as: "Is the friendship of Afghanistan of any use or not? If so, are the Afghans to be trusted as friends or not? If they are to be trusted, will the benefits resulting from their friendship compensate for the responsibility of their protection or not?" If all these questions were answered satisfactorily, the all-important one still remained: "Would the Parliament at home authorise them to carry out the negotiations or not? If it did authorise them to enter into such pledges and to face Russia, is it possible or not? If possible, will the gains be equal to the risks or not? And when the next Party comes in, will they agree to the arrangements of the Government that preceded them or not?" In short, their philosophy was just like the philosophy of an unwilling servant who was in attendance on his master, who was ill. The master said to his servant: "I am suffering; go fetch the doctor." The servant replied: "Perhaps the doctor will not be at home at this time." The master said: "I know he is at home." The servant replied: "If he is at home, perhaps he might or might not come." The master said: "He is sure to come." The servant said: "He will not have medicine, perhaps." The master said: "He has the medicine." The servant continued: "Sir, you know 
that death is certain, and perhaps, also, the medicine may not have any effect to cure you, after so much trouble; so what does it matter whether it is in your Kismet that you die a few days earlier or later?"

I do not blame the Indian Government, because they had seen no benefit from the friendship of the Afghan nation, as that friendship had always ended, through the mistakes of one party or the other, in troubles, war, and the loss of life, without any gains whatever; and after the behaviour of Amir Shere Ali and Yakub Khan, they could not place very much confidence in an Amir of Afghanistan.

In addition to these doubts, there were many other obstacles in the way of our coming to a better understanding with each other. It is a well-known fact that the Eastern ideas, views, and ways of looking at matters are very different from the light in which the same matters appeal to the Western mind: they are as widely separated as east is from west. There were so many people trying to make mischief that had it not been, on the one side, for the far-seeing wisdom of the Marquis of Ripon, Sir Alfred Lyall (Foreign Secretary), Sir Donald Stewart (Commander-in-Chief), Sir Lepel Griffin and several other English officials of the Indian Government-and on the other hand had I not been fully aware of the Russian promises to Amir Shere Ali, and the ruin of Shere Ali and Yakub-the mischief-making people would certainly have made a quarrel between us.

Amir Shere Ali Khan, his family, friends, and 
partisans, and many other people of Afghanistan who were in exile in India, were trying to poison the minds of the British Government officials against me. And in addition to this, some Afghan chiefs who were accustomed to plunder the country and fight against each other, could not bear my punishing them for their misbehaviour. They therefore kept on repeating tales to the Indian Government, that the Amir was killing all those who had served the British, and who were friends to the British and the foreigners; and it was natural that these reports should make some impression on the minds of the Indian officials. Though the Marquis of Ripon, his counsellors and myself, were all anxious to avoid these misunderstandings, yet still I thought it necessary that an interview should take place between me and the Viceroy of India, which would clear up any suspicions from the minds of both of us. At such an interview we could discuss verbally important matters which could not be settled by writing. But a favourable opportunity for the meeting did not occur until the Marquis of Ripon left India, and was succeeded by Lord Dufferin.

At this time certain other matters came to the front which made it necessary that such a meeting should take place between the Viceroy of India and myself immediately; not only to give and take friendly assurances, but for other matters of a very grave nature, which required deliberate consideration. These were the following:

(1) The Russians were circulating rumours through the Press that the English had not left Kabul on account of their friendship with the Amir Abdur 
Rahman Khan, but had run away from that country. I therefore wished that by going myself to India, and having a cordial and friendly meeting with the Viceroy, the facts should become known by the public and the world generally. They would see that these two nations were great friends and trusted each other entirely, if the Amir of Afghanistan, an independent ruler, had himself gone out of his way and had left his own dominions, accompanied by only a small body-guard, to see the Queen's representative and the Queen's son, in India. Such a course would contradict all these false rumours, and prove what a true and real friendship existed between my Government and that of England, and add to the prestige of the British Government; the safety and strength of India and Afghanistan resting on the fact of their mutual friendship being publicly known.

(2) Before this year, 1885, there were four great obstacles and strong barriers in the way of Russia's aggressive designs upon India ; namely, the Desert of Khiva and Bokhara, the Pamirs, Persia, and Herat. Now I who knew all about the Russians' plans, plots and schemes towards India, having been associated with them for so many years, persisted in urging the Indian Government to take precautions against Russian aggression, and warning them about the schemes and plots of the Russian advances towards India. I asked them to pay most serious attention to fortifying the North-Western frontier of Afghanistan, including Herat. Nobody, however, took the trouble to carry out and follow my advice; indeed there were some officials who doubted the fact of the Russian 
advances, placing their full confidence in the Russian promises and treaties.

At this time the Russians having crossed the desert of Khiva, oceupied Merv and Sarakhs, which are the gates of Afghanistan, and there was thus opened communication between Turkestan and St Petersburg, both by railways and steamers. After they had fortified Merv and Sarakhs, for the purpose of reinforcements, they were exhibiting much activity in the direction of the Oxus.

The relations between France and Great Britain were in rather a critical condition at this time, owing to the fact that Great Britain had occupied Burmah and Egypt; the Russians, therefore, who were seeking an excuse to march towards Afghanistan, found this a suitable opportunity for their plans. To decide upon and consider such complicated matters, and to fortify the frontiers of Afghanistan, so as to be prepared for a Russian attack, it was necessary that no time should be wasted in written communications, and that matters should be settled verbally between me and the Viceroy without a moment's loss of time. Notwithstanding my warnings, however, the Russians took the province of Panjdeh, which belonged to my dominions, in 1885 , as has been mentioned before. Had I not marked out a hard and fast boundary line between the Russians and myself, they might have taken some other places as well.

I think it necessary to mention here that the Russian policy of aggression is slow and steady, but firm and unchangeable. If they once make up their minds to do a thing, there is no stopping them, 
and no changing their policy. It is not the case with them, as with some other countries, that every party that comes into power can undo the work that has been done by the party before itself. Their habit of forward movements resembles the habit of the elephant, who examines a spot thoroughly before he places his foot down upon it, and when once he puts his weight there, there is no going back, and no taking another step in a hurry until he has put his full weight on the first foot, and has smashed everything that lies under it. Russia has moved and marched towards India during the last sixty years very slowly but firmly. She has not occupied a place without being first certain of success. And after taking a place she makes amnouncements and a great noise about keeping the peace; and signs new treaties and agreements, swearing all vows and oaths that she will never proceed any further. These vows last until, but no longer than, the time when the newly-annexed place is strongly fortified for reinforcements, and the Russian influence has spread all over it. After this Russia takes another place that may be lying near to the first without either going very far or retreating again. When this place is in its turn properly absorbed, she moves on to another, treaties or no treaties!

I do not go so far as to say that she breaks oaths and treaties without making some explanation and excuse. There is a saying that "treaties are made to be broken."

When any strong nations desire to break a treaty they do not think very long about finding an excuse. 
They urge that they were justified in their action by the misbehaviour of the weak nation. This reminds me of a story which runs as follows: A hungry bear employed a lamb to guide him to all the places where other animals were living, and made a promise that he would not eat this lamb, who was his guide and counsellor. All the other animals of the jungle having been eaten by the bear, there remained nothing but the lamb. Thereupon the bear said in an angry voice: "I must eat you, because you have insulted me and thereby broken your treaty." The poor lamb looked at him, and said: "My lord, how should I dare to insult you?" And the bear replied: "Your father insulted my father." But the lamb said: "There is no evidence about that, as both of our fathers are dead." The bear answered: "So-and-so told me." The lamb replied: "He told you a lie." The bear now got furious, and said: "Now you really have insulted me by calling my friend a liar before my face." And he fell upon the poor lamb and ate him up.

(3) The other matter which led to this meeting was as follows: I had promised the English Government that I would not communicate with Russia or any other Foreign Government without their knowledge and advice; the English on their part had given me a promise that they would protect my country against any foreign aggressor. This my promise to the British Government, and my having broken off all connection with the Russian Government - who looked upon me as being under an 
obligation to them for having eaten their salt for so many years, and as having given me notice and permission to come to Afghanistan ended in my taking the throne of Kabul. The Russians had sent me to Kabul as their candidate, and, personally, I am under great obligations to them, and shall never forget their kindness, because ingratitude is the very worst sin. But, notwithstanding this, I am not entitled to sell my country and my people to the Russians in compensation for my personal gratitude towards them. The nation and the country have been delivered into my hands by God for protection, and I have been appointed only as a guard to save this human flock for Him. It would be a very great disgrace for any sentry or guard to hand over to his friends any property entrusted to his care to watch over; and no guard, of course, would ever do it so long as he was alive, and had cartridges for his rifle and the blade of his sword to cut with. It was therefore natural that the Russians should be offended with me for joining the English.

What keeps treaties and promises is only the sense of honour and conscience implanted in all of us by God: without this, treaties have been and can be broken; examples of this are not few. If a treaty means only to be honest and to keep one's word, then the promise, written as well as verbal, which was given me on the 20th of July 1880, by Sir Lepel Griffin, to the effect that the British were responsible for protecting Afghanistan against any foreign aggressor who should attack the country unprovoked by the Afghans, was sufficient. 
Some of the officials, however, were of opinion that this promise was not given in the form of a treaty or formal official document. I therefore had the same document confirmed officially by the Marquis of Ripon, in 1883. But, notwithstanding that, I was anxious to get a confirmation of the same promise in the most emphatic language and plain words from the Viceroy of India himself, and to have that promise declared and ratified in public audience, for the knowledge of the world in general. For this purpose I wanted to have an audience with the Viceroy, with a view to clearing away any suspicions and doubts upon this point.

Russian had never had any wars with Afghanistan, and these two nations, Russia and Afghanistan, have never killed each other ; there was therefore no enmity between them, and I hope that this is still the case. Russia has, consequently, no reason for attacking Afghanistan, or for interfering in Afghan affairs, beyond the fact that Afghanistan is friendly with Great Britain; that she has no connection now with Russia, and that she lies as an obstacle between Russian territory and India, thus barring the way for Russian aggression upon India. Considering, therefore, that the only reason that could be given by Russia for attacking Afghanistan is the friendship existing between that country and England, justice demands that, treaty or no treaty, England should be responsible for the safety and protection of Afghanistan, and that both these nations should stand or fall together; that at the time of difficulties England should protect Afghanistan, and keep her 
word without discussing the interpretation of the words "if" and "but," in the pledges given by them!

Hence Lord Dufferin (who was such a statesman, that a wiser and more clever ruler than he has never ruled in India) perceived the necessity for such a visit as I had proposed immediately after he had taken over the government of the Indian Empire into his hands. He selected the town of Rawal Pindi as the place of meeting, and accordingly invited me to visit him there. I could desire nothing better than this, and hurried off to India without losing any time. I arrived there on the last day of March. A very cordial and grand reception was given me: the Viceroy, with Lady Dufferin, the Duke and Duchess of Connaught, with many of the most eminent officials of the Indian Government and the Indian ruling princes, received me very warmly. The visit was most successful, and, having completed the objects of the visit, I left Rawal Pindi for Kabul on the 12th of April. All the conversations which took place between me and the Viceroy were published in a small pamphlet for the information of my people on my return to Kabul. It is not therefore necessary for me to give any details; I will, however, give a few points.

This visit cemented our friendly feelings so much, and cleared away all doubts so far, that during Lord Dufferin's viceroyalty there were no misunderstandings between him and me. All the lies which were repeated to the Indian Government against me were washed out, and the friendship of the two nations 
was publicly announced to the world. The matters which could not be put in writing were decided in personal conversations; these referred to the fortifications of the North-West frontier of Afghanistan. The Viceroy gave me a heavy battery, rifles, and cash, and promised to give further assistance when required.

A restriction was thus placed upon the further advance of Russia; I reminded the Viceroy that, notwithstanding my warnings and prophecies of the Russian advance, either owing to precaution or owing to party disputes, no action had been taken, and the Russians had broken down one of the four obstacles which were in their way, namely, they had crossed the desert of Khiva and Bokhara, and taken possession of Merv and Sarakhs. "Not only that," I continued, "but they have taken Panjdeh, which belonged to me, during my stay in your camp. The next thing they will do will be to take the Pamirs; the third will be that they will take Persia under their influence; and fourthly, they will attack Herat or any other Afghan town which may suit them at the time. We must therefore take the Pamirs before they do." But, alas! nothing was done, and to-day the Russians occupy the Pamirs, as I had prophesied. Lord Dufferin replied: "For the protection of Herat and your North-West frontier, every sort of assistance in the shape of money, arms, war materials, as well as engineers or other English official help, shall be given to you. And in case of an attack from Russia upon Herat, Great Britain is prepared in every way to meet the difficulty. We have vOL. II. 
made preparations for this purpose." His Lordship further promised in plain and clear words to defend and protect the integrity of Afghanistan, and to repel any unprovoked aggression by any foreign power.

I refused the offer of the engineers or other English official assistance, with thanks-this kind of help would not be received by my people very warmly-and I accepted all his kind offers and kind promises, I myself promising in return that as long as the British kept their word they would find me true.

On the 8th of April the public audience or Durbar was held, when, on one side of me, the deputy of Her Gracious Majesty the Queen, the Marquis of Dufferin and Ava, was standing; on my other side being Her Majesty's son, the Duke of Connaught. I then and there declared and announced this promise of the British Government to be responsible for the safety and integrity of Afghanistan to the public at large. I did this that every one present at the Durbar, and the world, should know about the pledges which Great Britain had given to me, that they would take upon themselves the responsibility of expelling any foreign power making aggressive attacks upon my country; and I added that in return for this I also would be true to my promise, and faithful in my friendship to Great Britain. To this Lord Dufferin assented. I might mention here that on the 6th of April a parade of the army was arranged for my inspection, and I, who have been a soldier throughout my life, could not help admiring the splendid army which the British Govern- 
ment possesses. A nation which possesses such an army has very little to fear. The same night at dinner the Viceroy proposed to drink a toast to my health, in responding to which I said: "I pray for the long life of the Queen-Empress of India, her Government, her family, and all the well-wishers of her kingdom, in which, to my belief, lies the safety of Afghanistan." I emphasised again and again this one point, that Russia would certainly take the Pamirs, and the same point I mentioned in 1886 , when the boundary line to the North-West of Afghanistan between that country and Russian territory was being marked out. I then urged that this line should be carried further from Khwaja Salar up to the Pamirs and Chitral, before Russia could take possession of the Pamirs. But this was not done, and the Russians took the Pamirs. Now, at this time, my third prophecy is being fulfilled, namely, the Russians have taken Persia entirely under their influence, and the result will be that they will take a concession from the Shah of Persia to make a railway line through the Seistan Desert towards Kandahar and Quetta, and also will put their foot on the Persian Gulf.

In 1889, when I was in Turkestan, I informed Lord Lansdowne, the then Viceroy of India, that it was a very suitable opportunity to fortify the North-West frontier of Afghanistan, by erecting forts and placing guns all along the frontier, to protect it from Russian aggression. I had a very plausible excuse to offer, if Russia should make any objection, because at that time my country was in an unsettled condition, and I was there myself. My warnings, however, took 
no effect as usual, and now it is too late, because the Russians will say: "Why are you gathering your army on your frontier and placing guns?" It is very sad that I, who know all the schemes and plans and plots which are secret in the hearts of the Russians, about their future movements in the East, should have my warnings disregarded; that nobody takes any notice of what I say. I do not know whether the British officials are ignorant of the fact, or whether they are too cautious to give it out.

It was a great delight to me to meet Lady Dufferin, who was the cleverest woman I had ever seen, and the Duke and Duchess of Connaught, to whom I found that the hearts of all their Indian subjects were devoted. The Duke of Connaught is a very kindhearted, gentle-natured, honest, straightforward, smart soldier, and it is only natural that all the army should worship such an officer. There was one sad point that I noted in this my visit, which left a melancholy impression on my mind, and grieved me very much. It was the condition in which I saw the ruling Nawabs and Rajahs of the Punjab. The poor things were all dressed like women, wearing diamond pins in their hair, earrings, bracelets, necklaces, and other pieces of jewellery usually worn by women. The straps of their trousers were jewelled, and little bells were hanging in front of their trousers as low as their feet. They were sunk in ignorance, laziness, and indulgence. They did not know what was going on in the world nor what was in it. They were quite unable to walk, because they have never been in the habit of walking, thinking it minimised their 
prestige. They spend their time in drinking or smoking opium. I pitied these poor things, upon whom I looked as effeminate men, and I pitied the poor subjects who were to expect justice and administration at their hands.

I learned another lesson also from this visit, which was that the more chances I myself, my sons, and my officials have of seeing and knowing the British people, the better it will be, because I discovered that such officials as, for example, Lord Dufferin and many others whom I had seen from time to time, soon became good friends, and that the more we knew of each other, the higher was our opinion of each other, and this made matters run smoothly. I also thought that such visits cleared away and dispersed the old hostile feelings which once existed between these two nations, so that our friendship would be recognised more and more, and people would not have any ground or opportunity for saying things against us. I also discovered that it is best to settle certain matters verbally.

I made up my mind to visit England myself, as well as to send my representatives there from time to time; also to engage the services of English men and women for the Government of Afghanistan, so that intercourse between London and Kabul should be constant. This would bring the two nations into closer touch than they had been in hitherto. But alas! the more I try to bring England and Kabul near each other, the more some of the English officials seem to try to keep them apart and separate them.

Towards the end of Lord Dufferin's Viceroyalty 
certain matters arose that required to be settled personally by myself with the Mission that was invited to Kabul for that purpose; the opportunity, however, did not occur, and in November, 1888, Lord Dufferin left India, to the great sorrow and regret of all the subjects and friends of the Indian Empire. The people had never seen such a wise statesman as their Viceroy, and the regret at parting with him was universal and deep, and Lady Dufferin's residence in India was of hardly less importance than that of her husband. She was the first founder of the noble institution of the family hospitals for the Indian women; and for this act alone, if for no other, her name will always shine in the history of India for ever, as one of the noblest of ladies, whose sympathies did more for her sex than any other of her predecessors.

Lord Lansdowne succeeded to the Viceroyalty of India. From this date the period of difficulties and misunderstandings between Afghanistan and Great Britain recommenced. The details connected with there I will not give in this book; first, because the book is not large enough, and secondly, because it is not expedient to give them out publicly. It will be sufficient to say that at this time those great men and lovers of peace, who used to be the advisers of the Viceroy, such as Sir Donald Stewart, Commanderin-Chief, and others whose names I will not give for fear of being looked upon as a flatterer, had left India. General Amir Ahmad Khan, my envoy with the Indian Government, who had managed, by his wisdom and experience, to strengthen the ties of friendship during the reigns of three Viceroys, had left this world for 
Paradise. Lord Roberts had succeeded to the office of Commander-in-Chief, and he was in favour of the "Forward Policy." The Indian Government began to interfere with the chiefs on the borders of Afghanistan, and having cut a tunnel through the Khojak Hill, pushed their railway line towards New Chaman, right on the borders of Afghanistan, from which direction they moved their forces nearer to the borders of Afghanistan, and began to make fortifications and preparations to such an extent that the ignorant and uneducated Afghans gave out that the English railway was going to enter Kandahar, and the English army was making a Charhai (an attack) on Kabul. It was necessary, therefore, that they should all be ready for starting a holy war. At the time I received letters from Lord Lansdowne, addressed to me in a tone that I was not accustomed to ; and very different to that adopted by other Viceroys of India, for he wrote in a dictatorial manner, advising me upon matters of internal policy in the administration of my kingdom, and telling me how I ought to treat my subjects. This I could not submit to, because, if I had not retaliated, the English Government would have thought they had a right to interfere in my internal policy, which would be quite against the terms of our treaty.

At this time I was occupied in making the fort at Dehdadi, which commands the roads from Russia to Turkestan as well as fortifying other North-Western frontier positions. I also purposed visiting Herat to see about the fortifications there, and to arrange for volunteers from the Durani and Ghilzai tribes, lying between Herat and Kandahar. At this time I re- 
ceived letters from Kabul and Kandahar to the effect that the English were pushing their railway line right into Afghan Territory, and were massing their forces near the borders of my country; they also stated that the Afghan border chiefs, who were independent and had kept aloof so far, were beginning to interfere. Some people went so far as to say that the English intended to keep Kandahar and Kabul. These reports, added to the strange letters of the Viceroy, alarmed me. My presence on the spot was urgently needed, and, notwithstanding the fact that I was immersed in the important business of fortifying my North-Western frontier, I was obliged to hurry back to Kabul, where I arrived in the summer of 1890. I dismissed and recalled to Kabul Sirdar Mahomed Khan, my Governor of Kandahar, who had not opposed this railway line being brought into my territory, nor had he given me any information about it. $\mathrm{He}$ also owed money to the Government Treasury. During the time he was putting his accounts in order, he died at Kabul.

The Government of Lord Lansdowne was not satisfied with creating unpleasant anxieties for me, but went further still, even so far as to stop the guns which I had bought with my own private money in India, not allowing them to be brought to Kabul. More than that, it was reported to me by my merchants, that the frontier officials stopped the private goods of the Afghan merchants-iron, steel, copper, etc.-on the excuse that such goods were required to make war materials, and so long as they were not certain about the friendship of Afghanistan, they said they could not allow such things to be imported into Afghanistan. 
There could not have been a greater insult offered to me; I was humiliated in the eyes of my own subjects, my own guns were stopped, and the goods of private merchants also, which was a new thing in the history of civilized nations, between which trade is free everywhere. Had I been a hasty inexperienced Amir, like Shere Ali Khan and some others of the former rulers of Afghanistan, war would have been certain, or I might have fallen back upon Russia for support, which would probably have resulted in my ruin and fresh trouble for the Indian Government. I might also have written such a letter in reply to the Indian Government that it would have ended by their making war against me. But I was far too shrewd to give them any excuse for laying their hands upon. Not only did I refrain from any of the above-mentioned steps, but I also appeared to be perfectly indifferent. The Indian Government were so satisfied with my conduct that they took a further step at a very critical time when I was anxious about the Hazara rebellion in my country ; a rebellion that was so far-spreading in its influence all over Afghanistan, that even my own personal attendants had joined the rebels, after deserting me. Some people from the city of Kabul and from Dehmazan, a suburb of Kabul, also joined the rebels. The Hazaras throughout the whole country had taken up arms against me, and there was a fear that a general rebellion would take place. At such a time as this, all the help I received from the Indian Government was a sort of ultimatum, saying that the Government of India could not wait for my indefinite and uncertain promises about inviting the British Mission 
to Kabul, and therefore Lord Roberts, the Commanderin-Chief of India, would be sent to Kabul with a large force as his body-guard. I considered the position very critical, to receive 10,000 soldiers, whom I was expected to receive as my guests. I had therefore to prepare 100,000 to receive them! I saw that the Indian Government was bent upon making trouble, so, without letting a single official of my Government, except my chief secretaries, know of my intention, I wrote a letter to Lord Salisbury, the then Prime Minister of Great Britain, and sent it to England by a friend. At that time Sir John Gorst was Under Secretary and Lord Cross Secretary of State for India ; to these I am thankful for putting my letter before Lord Salisbury, and though all the requests made in my letter were not granted, luckily the war was avoided. The misunderstandings, however, which existed between my Government and that of Lord Lansdowne were not quite settled until Lord Roberts left India, and General Sir George White succeeded him as Commander-in-Chief in India, and Sir Mortimer Durand's Mission's visit to Kabul in 1893. After this, I am glad to say, Lord Lansdowne and myself parted on friendly terms, to my great satisfaction.

In considering the past history of Afghanistan, I could not help noting the fact that any Viceroy who chose to make war could do so, as he had a free hand to deal with the Government of Afghanistan ; and as the Parliament in Great Britain heard only a one-sided story from the Viceroys, they naturally gave a onesided decree in the matter, and in favour of the Viceroy. This was owing to the fact that the rulers of Afghan- 
istan had no representatives, nor any means whatever of letting the Government in England know the other side of the question. I was therefore very anxious to have my representative at the Court of the Viceroy, as had always been the case, and, at the same time, to be able to communicate with the Government in England as well.

The necessity for such a step was forced upon me by the recent treatment of me by Lord Lansdowne's Government, which treatment had brought us to the verge of war. Any other Amir but myself would have either leant back upon Russia, which would have resulted in his own ruin, as in the case of Shere Ali, or would have given such promises to the Indian Government, as did Yakub, which could not possibly be fulfilled. Such promises would undoubtedly have brought ruin to them. All these instances in the past were a lesson to me; my predecessors had suffered from adopting such a line of policy, but I benefited by the lesson their mistakes taught me. It was not pleasant to me to think that the Government of Afghanistan was to a certain extent under any Viceroy of India who might be appointed, and that I, the Amir of Afghanistan, should be merely a tool and a puppet to be made to dance by a Viceroy. I am still anxious to relieve Afghanistan from this everlasting danger, because it is an independent kingdom, and there is no reason why it should not be treated as an independent kingdom. I also knew that by having my representative in London, the Afghan people, who know so little about the good-nature of the British people in England, and the power of the 
British Empire, would be better informed by their own countryman and representative who would be living in London; and the residence of an Afghan official in London would certainly inspire friendly feelings in the minds of the Afghans, and instruct them in the industries and sciences and civilisation of Great Britain, which would promote the ties and bonds of mutual friendship, and the two nations would come into closer touch with each other.

To attain this object, and for certain other reasons of which I thought it well to inform the authorities in England, and to pay my respects to the noblest lady that ever succeeded to any throne on this earth, I intended to visit England myself. I saw what advantages would accrue from opening my own channels of intercourse by visits to the English nation.

To my great pleasure this my desire was fulfilled by my receiving an invitation in the spring of 1894 , after Sir Mortimer Durand's return to England from Kabul. The offieial invitation was endorsed by Sir Henry Fowler, then Secretary of State, and the gist of it was, that Her Majesty was kind enough to invite me, or one of my sons, to go to England to visit her. I received other friendly letters also from their Royal Highnesses the Prince of Wales, the Duke of Connaught, and other State officials of Great Britain, expressing their desire to have the pleasure of seeing me. But, unfortunately, I fell ill at the same time, and my illness lasted so long and became so serious, that there was very little hope of my surviving. All my Court doctors, including Miss 
Hamilton, M.D., under whose treatment I was at the time, were alarmed by witnessing my sufferings.

Before I answered the invitation I received a letter from the Right Honourable Mr George Curzon (now Lord Curzon), saying that as he was travelling towards Chitral and the Pamirs, and was anxious to make my acquaintance, he would wait for my permission to come and see me. I accordingly invited him, and he was my guest at Kabul for a few days. Several friendly conversations took place between us, for though he did not understand Persian, and I did not understand English, we were able to communicate through Mir Munshi. From these conversations he appeared to be a very genial, hard-working, wellinformed, experienced, and ambitious young man. $\mathrm{He}$ was witty and full of humour, and we often laughed at his amusing stories. Though Mr Curzon's visit was a private and friendly one, and not in any way in an official capacity, yet still we touched upon and discussed all the important affairs of my Government. The special topies of conversation were as to the North-West frontier of Afghanistan, and as to my successor to the throne. My sons, Habibullah Khan and Nasrullah Khan, also invited $\mathrm{Mr}$ Curzon to their houses, and they all passed very pleasant evenings. I was so pleased with his visit that it still further added to my desire and anxiety that I, my sons, and officials, should see other members of the English aristocracy and officials as often as possible.

But to my great disappointment and sadness, my illness deprived me of this pleasure; and my eldest 
son, who was well endowed with the gifts for such a visit, being able also to speak a little English, could not go, for fear of anything happening to me during his absence, and, besides, the whole burden of the Government rested upon his shoulders at that time. The only other grown-up son I had was Habibullah's full brother Nasrullah, and he was appointed accordingly to visit England on my behalf.

In addition to the letters that were given to him addressed to Her Majesty the Queen, and to the other princes of the Royal Family and Government officials of Great Britain, he had a book of instructions given him by me, which he was ordered to follow throughout the whole of his journey.

My son left Kabul in April 1895, arriving in London in May. He left London in the month of August, and returned to Kabul, by way of Karachi and Kandahar, in the winter of the same year.

To my great disappointment, however, this visit caused a great deal of unnecessary expense to the Governments of both countries, for it proved a complete failure.

It is the custom, not only among the aristocracy, but among our poorest people as well, that a guest should never return in despair at his request being refused, even if he be an enemy; and it is considered impossible that any one should enter the doors of his host's house without expecting kindness. But my son, who was the son of a sovereign, 
and the guest of another illustrious sovereign, was returned with a dry but polite refusal to my request.

I think that the request that I had made, namely, to have my representative in London, or at least to allow of my communicating direct with the Government in England, as well as with India, was not put before the House of Commons in a proper light, otherwise many of the most experienced members of Parliament would have realised the advantages of this course in cementing the friendship of these two nations, and in strengthening and civilising Afghanistan. But I will dilate a little more fully upon this point in a later chapter, on "Future Policy." It must suffice to inform my readers at present that the usual communications are being carried on between India and Afghanistan in the old way, through the medium of their Mahomedan representatives at Kabul and Calcutta. This means that the whole world may make progress, and the circumstances and the positions of these countries may change, but in the old system of communication no improvement is to be made.

I will say a word or two to thank the Queen and all the members of her royal family, the nobility, and the British public for their kindness shown to my son as my representative, and, of course, the cold treatment of a few officials does not make me forget the obligations that I am under. I have been much pleased by the kindness shown to my son by the Queen, one proof of which is, that she bestowed the honour of G.C.M.G. on my two sons, Habibullah and Nasrullah. 
144

ANGLO-AFGHAN RELATIONS

[CHAP. v.

My son wrote a book telling of his travels and experiences of English life; this was printed at the Kabul Press, but was not publicly published, as I did not think it wise. ${ }^{1}$

'Miss Hamilton, M.D., has made, I believe, a translation of some portions of Nasrullah Khan's book of "Travels," as well as of the book of "Instructions" given him to follow throughout his journey. 


\section{CHAPTER VI \\ THE BOUNDARIES OF AFGHANISTAN AND THE DURAND MISSION}

THE readers of my book will by this time have formed an idea of the way in which I had made a kingdom of Afghanistan, which before had been divided into so many independent States ruled over by separate chiefs; and how I had extended my dominions, which, at the time of my accession, were no more than the city of Kabul and Jellalabad, together with a few other places. They will have learned how I took possession of the Kandahar and Herat provinces in 1881, and those of Roshan and Shignan in 1883 (though the last-named was under dispute up to 1893 , when it was officially settled by the Durand Mission). In the same year I appointed my own governor, named Ghafar Khan Kirgiz as governor of Wakhan, instead of Ali Merdan, the native chief of Wakhan. This was a hill state to the south of Shignan; on the south of Wakhan lies Chitral. My readers have also seen how I extended my dominions by occupying Maimana in 1885 ; Hazarajat in 1893, and Kafiristan in 1895 ; though I had to subdue the last-named after the Durand Mission, by which it was decided to belong to my Government.

vOL. II. 
At the same time when I was occupied in breaking down the feudal system of Afghanistan and moulding the country into a strong consolidated kingdom, I was not unaware nor neglectful of the necessity of defining my boundaries with the neighbouring countries. I well knew that it was necessary to mark out the boundary lines between my dominions and those of my neighbours, for the safety and protection of my kingdom, and for the purpose of putting a check on their advances, and getting rid of misunderstandings and disputes.

I know that it has become a eustom in this century for great Powers to absorb small countries; and to carry out their desires of annexing the weak countries they adopt various modes and schemes. For instance, the first is by the partition of the weak nations, by which every one of the strong usurpers takes his share, and the justice given to the weak nations by these strong Powers reminds me of the story of a poor man, whose watch had been taken by a robber. He went to one of the chiefs of the robbers, who called himself a magistrate. But this magistrate said: "I cannot get your watch back, but what are you going to give me for my share?" The poor man cried hard for justice, saying that he did not come to give more, but to get back what had been already taken from him. The answer was: "There is no reason that you should give your watch to a weaker person than myself, and I not have my share?" He thereupon demanded the chain as his share. The man went to a higher judge, who took the man's ring in the same manner. Whereupon the poor man thought that if he went to the Lord Chief-Justice there would be no jewellery left at all, and 
his share would only be his turban and clothes, leaving him without a stitch of clothing to cover him. He therefore went home, contented with half justice. I believe that if the readers of my book will compare the story of this justice with the case of China, they will find that I am not very far wrong. The second mode is this: That the great Powers enter into underhand intrigues and understandings with each other, which they call statesmanship and policy, and agree with each other that "if you take such-and-such a country, and I take such-and-such, we will not interfere with each other."

The third mode of their taking these countries is this : That at a time when they are defining their boundaries with another Government, certain countries or provinces on which they have cast their eye they leave undecided; these they call neutral ; and they say to the neighbouring Power: "Now this must be left independent; neither must you interfere nor we interfere." By these pretences of calling such countries or provinces neutral, they cancel the claims of the neighbouring weak Governments to these provinces, which either wholly or in part belong to them. This being done, they begin to play their game in this so-called neutral country in such a manner that they give to the chief of the neutral territory an old worn-out riding horse, some old uniforms, and so many guns or revolvers, saying to him: "We will be friends with each other, and our friendship will be sufficient to save you from the attacks or aggression of your neighbour; and you are to be our friend and independent ally." The poor fellow thinks that there is no harm in being friends, so long as they acknowledge 
his independence; and that, on the contrary, it is to his advantage that they should take the responsibility of his protection against foreign aggressors. But very soon after, they easily find some excuse to accuse this neutral chief of having broken his promise of faithful friendship ; or sometimes they persuade his own subjects to appeal for justice against his cruelties to these illustrious judges. And after listening to one or other pretence like this, they take possession of his country. If the neighbouring Power says that this is against the treaty, and they must leave this territory neutral, they answer: "Ah, yes! it was left neutral at the time, but the ruler himself made a subsequent treaty with us, by which he placed himself and his country under our protection and our sphere of influence. This bars you from having any right to interfere in the affairs of the country which has been so many years considered under our influence and included in our sphere of Government, therefore you have no right to interfere with our belongings!" And there the matter ends.

In this manner the Russian Government took all the kingdom of Bokhara and the provinces lying to the North-West of the Oxus on the borders of Afghanistan under their influence and protection, and this influence and protection ended in their swallowing all these countries. On the other hand, the Indian Government took all the provinces lying to the South-East and North-East of Afghanistan, which used to belong to the Afghan Government in early times, under their influence and protection. They gave them the name of "independent," and having called them the neutral states between Afghanistan 
and India, went on taking them under their influence day by day. The chiefs of these bordering tribes were in the habit of coming to the Afghan rulers in the summer, when it was hot in their country, and obtaining money and robes of honour from the Amirs of Afghanistan by saying that they were their friends; and in the winter they used to go to the Indian officials and take money from them, so that both the neighbouring Governments looked upon them as being under their protection, and, in fact, they were under the protection of these few robes !

Neither the Kings of Bokhara nor the Amirs of Kabul could ask Russia or England to keep away from occupying these independent provinces; nor did Russia or England, on their own parts, poach on each other's share, because the answer would have been that "this country is under our sphere and protection, and therefore you have no right to interfere."

Seeing that every Government was trying to get hold of as much as it possibly could, I also tried to take as much share as possible in these provinces which formerly belonged to Afghanistan and were now under independent chiefs, by making friends with them. At the same time I also took steps to define my boundary lines with my neighbours before their further advance.

In the matter of marking the boundary lines, it was no trouble to settle these questions with the Persian and Chinese Governments, because they had neither power nor intention to occupy any piece of land within the sphere of Afghanistan; so without 
any difficulty or dispute the boundary lines were marked out between Afghanistan and Persia, taking the line from Koh Malik Siyah to near Zulfikar; and in the same manner a small corner of Afghanistan near Wakhan and Roshan which joins with the Chinese frontier. This was also settled without any dispute.

\section{The Division of Boundaries between Russia and Afghanistan.}

The most difficult and most important boundaries to be divided and marked out were those between my Government and the Governments of my two most powerful neighbours, England and Russia, the two greatest Powers in Asia, if not indeed in the world. They are the greatest absorbing nations upon the earth, and though the Eastern countries they have already conquered are dying of perpetual famines they, for reasons best known to themselves, go on taking as much more every year as they can, constantly crawling forward. My country is like a poor goat on whom the lion and the bear have both fixed their eyes, and without the protection and help of the Almighty Deliverer the victim cannot escape very long.

I first took steps to settle my North-Western frontier with Russia through the medium and intervention of Great Britain, and after the usual communications with the Indian Government on the subject, a joint Commission of the Indian Government officials and my officials was appointed in the 
month of July 1884, to settle this question. The head of the English Commission was General Sir Peter Lumsden, and the head of the Russian was General Zelenai.

In reply to a letter from the English General, I wrote to him that "during my stay in Russia, I did not give them any promise or pledge which they could put forward against me at present, and therefore I am not afraid of them in any way; and as long as I have power I am not going to leave one fragment of the land of Afghanistan to the Russians. You must therefore carry out and mark the boundary lines between Russia and my country with vigour and courage." But alas ! the result was not satisfactory.

The Russians were irritated by my fixing the boundaries between us, which meant putting a check to their further advance, and especially because I was settling these boundaries through the medium of the English. In consequence of this they kept advancing towards the borders of Afghanistan as quickly as possible. As I had seen through their motives in taking Panjdeh, I tried hard to persuade the English to give me permission to send further armies to fortify Panjdeh, and I argued that if there were no war, there would be no harm in my armies being stationed in my own territory. But the English Government did not listen to my advice, and the consequence was that many lives were lost and Panjdeh was taken by the Russians in 1885, as has been mentioned before.

In the month of May 1885, the Viceroy wrote to 
me that the Russians had consented to evacuate and leave Zulfikar for me, instead of Panjdeh, the frontier line running North of Gulran and Maruchak, and the Viceroy wrote that this plan was accepted by the Russians. I answered the Viceroy's letter accepting this decision, and asking him to send me a copy of the understanding as mentioned above.

On the 9 th of May 1885, Colonel Sir West Ridgeway was appointed in place of General Lumsden. It was reported to me at first that Sir West Ridgeway was not satisfied with all the Sanads (charters) which my subjects could produce to defend their claims for their land, and he still insisted on asking for further Sanads, which irritated the Afghans, and I was displeased about it; yet in the end I found that Sir West Ridgeway's inquiries and requests for further eharters was a proof of his far-seeing wisdom and his friendly feelings towards my subjects, in that he wished to get as much evidence as he could to make the Afghan claims stronger. $\mathrm{He}$ succeeded in settling the whole Boundary Question without any further fighting or trouble, and after settling the Boundary Question, he, with his companions, visited me at Kabul, on their way back to India in October 1886. I was so pleased with their services that I showed them every hospitality in my power, and gave Sir West Ridgeway, Kazi Aslam Khan, Colonel Holdich, Colonel Yate, and several other members of the Mission, gold medals of honour. I know that Sir West Ridgeway is a very clever statesman who has a great future before him in whatever office he may be appointed to. I hope he will carry all his undertakings through with success. 
On the 22nd July 1887, the final protocol was signed at St Petersburg, and on the 1st of August, Lord Dufferin having written me a letter about it, received my warm thanks for the help which the British Empire had given me in marking out my North-Western boundary.

In 1893, again, a dispute arose between the Afghans and the Russian subjects about the irrigation of their lands near Chaman-i-bed (Meadow of Willows). For the settlement of this dispute Colonel Yate was appointed by the Indian Government, and he decided the question without any serious conflict.

Sir West Ridgeway's Mission had decided the Boundary Question from Zulfikar to Khwaja Salar only; and though at the time I requested the Indian Government to carry this boundary line up to the Pamirs, it was not done. And though according to the Treaty of 1873 the Russians had agreed that Badakshan and Wakhan should be included in Afghanistan, and Roshan and Shignan formed a part of Badakshan, yet as Roshan and Shignan command the roads from Russia towards India, the Russians were planning to take possession of them. But I had foreseen their policy, and had appointed my governors to occupy these countries before the Russians could enter them. I had a double right (1) because they were included within my dominions according to the above-mentioned Treaty of 1873 , and (2) because the King of Bokhara had occupied one portion of Darwaz towards the left bank of the Oxus, which justified me in taking possession of those parts of Shignan which lie on the right bank of the stream flowing from Lake Victoria, or Wood's Lake. This 
occupation of the above-mentioned territory by me led to a skirmish between Colonel Yanoff and my official, Shams-ud-Din Khan, at Somatash, on the 24th of July, 1893, which has been mentioned elsewhere.

This matter was settled in the month of November 1893, between me and the Durand Mission, after which I recalled my troops from the above-mentioned provinces in 1894, and oceupied Darwaz instead. In the month of March 1895, this agreement was settled between Russia and England, that the Cis-Oxus portion of Darwaz should be ceded to Afghanistan by Bokhara, and the Afghans should evacuate those portions of Shignan and Roshan which lie on the right bank of the Punjah and the Oxus. The stream issuing from Lake Victoria, or Wood's Lake, being a second time held, the boundary line of Afghanistan was fixed, and, thank God! since that time up to the present day, I have been relieved from the perpetual quarrels and disputes about my North-Western frontier, and up to this day there is peace. I hope God will keep this peace for ever to save the lives of His human flock.

\section{The Division of the Boundaries between India and Afghanistan and the Durand Mission}

Having settled my boundaries with all my other neighbours, I thought it necessary to set out the boundaries between my country and India, so that the boundary line should be definitely marked out around my dominions, as a strong wall for protection.

I requested the Marquis of Dufferin, and afterwards the Marquis of Ripon, to send some of their most 
experienced officials as a Mission to visit me at Kabul, for the purpose of discussing certain matters, and also I thought it better to exploit this question of the boundary with such a Mission. The Viceroy himself was not unaware of the advantages of a Mission, and I requested that Sir Mortimer Durand, the Foreign Secretary, might be appointed as the head of it; but unfortunately, in the first place, I fell ill, and afterwards Ishak's rebellion took place in Turkestan. This postponed the Mission question, and I left for Turkestan. On my return from Turkestan in $\mathbf{1 8 9 0} \mathrm{my}$ relations with the Indian Government were the same as I have mentioned before; in consequence of which I sent a letter to Lord Salisbury, who pointed out that I should settle the misunderstandings then existing between my Government and the Government of India with the officials of the Indian Government.

At this time Lord Lansdowne again wrote a letter to me, telling me that he had appointed Lord Roberts to be the head of the Mission. I was busy at this time in the Hazara war, and it was also against the opinion and desire of the people of Afghanistan to invite Lord Roberts with a large force to enter Afghanistan. I was afraid of some serious trouble arising out of this Mission. Many of the relatives and friends of the Afghan people had been killed either in fighting against Lord Roberts, or in being punished by him at the time of the last Afghan war, a eircumstance which made it unwise to allow him to enter Afghanistan with such a large force. I also thought that Lord Roberts was a 
soldier; and that for discussing the most complicated State affairs and foreign policy a statesman was required, and not a soldier; especially not a soldier whom I believed to be in favour of the "Forward Policy." It is only natural that a soldier should be fond of fighting and making war, just as statesmen and sovereigns are fond of making peace and avoiding war. More than that, some people told me that Lord Roberts' time in India was over, and he was anxious to continue as Commander-in-Chief in India if his time was prolonged. But this could not be without some trouble occurring on the North-West frontier of India, on which he was considered a great authority. It was to his own advantage to end the matter rather by war and trouble than by peace; I do not believe in this report myself; I think it is nonsense. But in any case $I$ thought it an unwise and unsuitable time for the Mission to assemble, and accordingly postponed it.

The Viceroy was so insistent on this matter that he addressed a letter to me, which was practically an ultimatum, to the effect that "the Indian Government cannot wait for your indefinite promises of uncertain date, and therefore after such-and-such a time, will draw its own conclusions." I was seriously ill at the time, and I asked Sirdar Abdullah Khan Tokhi and Mir Munshi Sultan Mahomed Khan to select one Englishman out of those who were in my employ to be sent from Kabul to see the Viceroy, so that the matter should not become serious and irremediable. In short, I succeeded in delaying the matter in this way, and I immediately posted a letter 
to the Viceroy on this subject, saying that "Mr Pyne is going to see your Excellency, taking with him my letter, to make all the necessary arrangements about the Mission." This message was intended to satisfy the authorities in India, and to prevent their taking any serious steps in the matter. After posting this letter I gave Mr Pyne one letter for the Viceroy and another addressed to Sir Mortimer Durand, the then Foreign Secretary; and bade him, Mr Pyne, go to India, with instructions to travel slowly, and if possible to postpone or delay the Mission for a few days, so that Lord Roberts, whose time for leaving India was very near, should leave for England. I requested the Viceroy to send me a map, having marked out the boundary lines as they proposed to decide them approximately, to show me which parts of Yaghistan (the land of the unruly) they proposed to take under their influence and sphere. I succeeded in this plan; Lord Roberts left India after writing a letter to me, expressing his regret at not having the pleasure of seeing me, and I at once invited the Mission to visit Kabul.

It is necessary to mention here that in the map sent to me by the Viceroy all the countries of the Waziri, New Chaman, and the railway station there, Chageh, Bulund Khel, the whole of Mohmand, Asmar, and Chitral, and other countries lying in between, were marked as belonging to India. I accordingly wrote to the Viceroy a long letter of predictions about the frontier tribes; the abstract of the letter is as follows:

"As to these frontier tribes known by the name of Yaghistan, if they were included in my dominions I should be able to make them fight against any enemy of England 
and myself, by the name of a religious war, under the flag of their co-religious Muslim ruler (myself). And these people being brave warriors and staunch Mahomedans, would make a very strong force to fight against any power which might invade India or Afghanistan. I will gradually make them peaceful subjects and good friends of Great Britain. But if you should cut them out of my dominions, they will neither be of any use to you nor to me: you will always be engaged in fighting and troubles with them, and they will always go on plundering. As long as your Government is strong and in peace, you will be able to keep them quiet by a strong hand, bnt if at any time a foreign enemy appear on the borders of India, these frontier tribes will be your worst enemies. You must remember that they are like a weak enemy who can be held under the feet of a strong enemy, as long as he is strong; and the moment he ceases to be strong enough to hold him, the weak one gets out of his hold and attacks him in return. In your cutting away from me these frontier tribes who are people of my nationality and my religion, you will injure my prestige in the eyes of my subjects, and will make me weak, and my weakness is injurious for your Government."

But my advice was not appreciated, and the Indian Government was so anxious to get these frontier tribes from me, that they expelled my officials from Bulund Khel and Wana Zhob by force and threat of arms, saying that if they did not leave by such-and-such an hour, they would be compelled to leave. As I was not desirous of making war and enmity with Great Britain, I had instructed all my officials to leave the place immediately after receiving such notice from the Indian officials then in residence.

Timur Mirza Shah, ruler of Asmar, gave me the oath of allegiance in 1887, and put himself as well as his 
country under my protection against an expected attack from his powerful enemy Omra Khan of Bajaur ; and he being killed by one of his slaves, General Ghulam Haidar Khan, my Commander-in-Chief, occupied Asmar in December, 1891, which caused great indignation to the Indian Government, who had their eye on all these so-called neutral provinces: Yaghistan (Chitral, Bajaur, Swat, Buner, Dir, Chilas, and Waziri: all these countries are included in Yaghistan). The Government of India insisted upon my leaving Asmar; but as this was the gate of Kunar, Lamkhan, Kafiristan, and Jellalabad, provinces of my dominions, and it commanded the Pamirs and Chitral roads, the keeping of such an important gate of my dominions was as necessary as keeping Herat, Kandahar, and Balkh on the three other corners of my dominions. In the same manner they insisted upon my leaving Chageh.

In Kafiristan, throughout the whole of Yaghistan, of Baluchistan, and towards Chaman, also, the Indian frontier officials were making constant interference. The only thing that surprised me was, that on the one hand the Indian Government said: "We do not require any more country towards Afghanistan; we only desire to see Afghanistan a strong independent kingdom," and on the other hand having cut a tunnel through the Khojak Hill they were pushing the railway line into my country just like pushing a knife into my vitals, and rumours that they intended making a railway line up to Kandahar with or without my consent, were being circulated everywhere and discussed in Parliament, about which I was constantly 
informed by my agents, who send me all the cuttings concerning Afghanistan. In addition to this, Russia was making troubles with me about Roshan and Shignan.

It was in order to settle all these misunderstandings and troubles that I invited a Mission, under Sir Mortimer Durand, who being a clever statesman, realised that confidence begets confidence :

"Hearts have intercourse with hearts;

Affection creates affection, and hatred creates hatred."-SADI.

He, trusting his safety and protection under my care, started for Kabul.

He left Peshawar for Kabul on the 19th September 1893, accompanied by Colonel Ellis of the Quarter-Master General's Office, Captains MacMahon and Manners-Smith, Mr Clarke of the Foreign Office, acting as political assistants, Major Fenn (the Viceroy's doctor), and Mr Donald, and a few other Indian accountants, clerks, and officials. The Mission was met by my General, Ghulam Haidar Khan, on their entering Kabul; and I arranged Indaki, the building and residence of my son, Habibullah Khan, near Kabul, for their residence. After the first ceremonial Durbar, we soon started discussing matters. Durand, being a very clever statesman as well as a good Persian scholar, all the discussions were soon put right; but, to keep a record of every word which was uttered by Sir Mortimer Durand, myself, and other speakers of the Mission, I had arranged for Mir Munshi Sultan Mahomed Khan to sit behind a curtain without being seen or heard, or his presence 
known of by any one else except myself, to write down every word they spoke to me, or among themselves, either in English or Persian. He wrote in shorthand every word uttered by Durand and myself, and this conversation is all preserved in the record office. The short outcome of the whole conversation was this, that the dispute which was opened between my Government and that of Russia about the provinces of Roshan and Shignan was settled as mentioned above.

The province of Wakhan, which had come under my dominion, I arranged to be left under the British for protection, as it was too far from Kabul, and cut off from the rest of my country, and therefore very difficult to be properly fortified.

The boundary line was agreed upon from Chitral and Baroghil Pass up to Peshawar, and thence up to Koh Malik Siyah in this way that Wakhan, Kafiristan, Asmar, Mohmand of Lalpura, and one portion of Waziristan came under my rule, and I renounced my claims from the railway station of New Chaman, Chageh, the rest of Waziri, Bulund Khel, Kuram, Afridi, Bajaur, Swat, Buner, Dir, Chilas, and Chitral.

$\checkmark$ Two agreements were sealed and signed by me, and by the members of the Mission, relating to the boundaries agreed upon, and also saying that as the Government of Afghanistan had in a friendly spirit renounced its claims to certain provinces, as above mentioned, the subsidy paid annually would be 18 lakhs of rupees instead of 12 lakhs as heretofore. In addition to this, the Indian Government undervoL. II. 
took to give them arms and war materials as a friendly assistance, also agreeing that in future the Afghan Government should be allowed to buy and import any arms and war materials that they wished.

Two days before their departure all the English members of the Mission, together with Abdur Rahim Khan (their Oriental Secretary), Afzal Khan (British Agent at Kabul), and Nawab Ibrahim Khan, were invited by my son Habibullah to dine with him in the Baber Gardens. They were there received by my sons Habibullah and Nasrullah, and by Ghulam Haidar Khan (Commander-in-Chief), Mir Munshi, and two or three of my officials.

On the 13th of November a public Durbar was held in the Salam Khana hall where all the civil and military officers of Kabul, together with the chiefs of various tribes, were present, as well as my two eldest sons. Before the audience I made a speech to commence the proceedings, in which I gave an outline of all the understandings which had been agreed upon and the provisions which had been signed for the information of my nation and my people, and all those who were present. I praised God for bringing about the friendly relations which now existed between the two Governments and putting them on a closer footing than they had been before. I also thanked Sir Mortimer Durand and the other members of the Mission for their wise way of settling the disputes. After this Sir Mortimer Durand made a short speech, at the end of which he mentioned that he had received a telegram from the Viceroy of India, expressing his great pleasure and satisfaction 
about the newly completed agreements and our friendly understandings. $\mathrm{He}$ also mentioned that Lord Kimberley had expressed his satisfaction in the House of Lords.

All the representatives and officials of my kingdom who were present received a copy of the address of the deputation to which they had all set their seals, and in which they expressed their satisfaction and consent to the agreements and understandings, and their great pleasure and rejoicing at the friendship between the kingdoms of Great Britain and Afghanistan.

I again rose to my feet a second time and read this paper to the members of the Mission and the other members of the audience. This day Mir Munshi was not ordered to hide himself, but to write down all these three speeches, of which 2000 copies were published the next day and circulated in the country.

I will mention one example, showing what a high value is put upon the friendship of the British nation by my people, and the affection existing in their hearts and those of my officials. Two days before Sir Mortimer Durand left Kabul, I wanted to send the decorations and orders to him and the other English gentlemen who were members of his Mission; and there was a friendly contention as to who should be the favoured messenger to take these orders. My Commander-in-Chief, Mir Munshi, and a Kotwal, were every one of them anxious to take the medals and deliver them to the members of the Mission, as they all considered it a special honour to be allowed to perform this service, and that the British members 
should receive their orders from their hands. I sent Mir Munshi with the medals, instructing him to present them with his own hands, together with my thanks for their distinguished services. After delivering these medals to their recipients, Mir Munshi brought back their letters of thanks and gratitude, and the Mission left Kabul on the 14th of November, having greatly enjoyed their visit. The misunderstandings and disputes which were arising about these frontier matters were put to an end, and after the boundary lines had been marked out according to the above-mentioned agreements by the Commissioners of both Governments, a general peace and harmony reigned between the two Governments, which I pray God may continue for ever.

Perhaps it would not be out of place to mention that though Lord Lansdowne made a speech in June 1894, at the time of his leaving India, in which he stated that he had heard that this arrrangement was made in order that the frontier tribes should not trouble the Indian Government any more; yet, contrary to his prophecy and in accordance with my prophecy, the Chitral war, Bajaur war, Malakand war, Waziri war, and the Afridi war, have all taken place since then, with these same frontier tribes who came under the British sphere; because they have no further hope of coming under the rule of an Islamic ruler, and do not like to submit to British rule. 


\title{
CHAPTER VII
}

\author{
THE FUTURE OF AFGHANISTAN
}

"To God alone are the gates of the hidden mysteries open; no man can know what is to happen in the future except the AllKnowing Allah."-Kors.

No man can know what may happen to-morrow, and therefore I cannot be held responsible for what I shall say about the future of Afghanistan, whether it will come true or not; and if I did claim that I knew what was to happen in the future for certain, then my utterance would be in direct contradiction to the teachings of the Holy Koran. Yet still a shrewd observer can judge from the circumstances and signs of the times which way the wind blows, without claiming either to be a prophet or inspired. The readers of my book must be aware that I have had a much wider experience of the world and mankind during my life than any previous ruler of my family, they will therefore, I hope, have patience with me while I give a few hints and suggestions for the use and benefit of my successors and my people.

I will divide this chapter, accordingly, into two main divisions. One of these divisions will deal with 
the progress of the country itself, and will consist in giving counsels and advice concerning the policy of internal affairs, and the progress to be made in future in the various Departments and Institutions. As many of these points have been treated in detail, in previous chapters, I ask my readers to excuse unavoidable repetition of many matters concerning the progress and welfare of the country. I must bring forward these points in illustration of the close connection existing between many of the above-mentioned institutions and sources of progress, and the home policy of my Country. The success of the one depends upon the continued advance in the other. The second division will treat of the foreign policy of Afghanistan, and its diplomatic relations with the neighbouring Powers.

\section{Future of Afghanistan.}

\section{(1.) Home Policy and Internal Affairs.}

To the mind of the ordinary observer, Afghanistan may be in the condition described in the famous poem of Sir Alfred Lyall, where it is stated:

"The Afghan is but grist in their mill, and the waters are moving it fast,

Let the stone be the upper or nether, it grinds him to powder at last.

And the lord of the English writes: 'Order and justice, and govern with laws,'

And the Russian he sneers and says: 'Patience, and velvet to cover your claws ;'

But the kingdoms of Islam are crumbling, and round me a voice ever rings

Of death, and the doom of my country. Shall I be the last of its kings?" 
Yet, taking into consideration the condition of the country at the time of my accession to the throne, and the marvellous progress that has been made in such a short time, one cannot help thinking that there is every reason to hope and expect that Afghanistan will grow into a strong, consolidated, independent kingdom, by the help of the King of kings, the Almighty Allah.

In the teachings of Mahomed, which are the greatest legacy left by the Holy Prophet of Arabia, who made the sandy desert of Arabia into one of the most flourishing kingdoms in the world, the following phrase is found which is appropriate to my country. "When the Almighty Father wishes and desires to do a thing, the Divine Will changes the current of circumstances to suit the conditions to the necessity." Praise be to Allah! the means conducive to the future advancement and progress of Afghanistan are increasing every day.

There is no doubt that Afghanistan is a country that will either rise to be a very strong, famous kingdom, or will be swept altogether from the surface of the earth. This latter state of things would come about if the country came under the rule of an inexperienced and weak Amir. In this case the country would become divided, and the very name of the kingdom of Afghanistan would cease to exist. To illustrate my meaning, and make my statement clearer, I must say that it is impossible that Afghanistan should ever take a middle course. It is quite out of the question that it could ever exist as a kingdom if cut up into a number of small weak states. For 
if the Government were not strong enough and wise enough to protect the kingdom from aggression, without help from outside, the country would surely and certainly be annexed by one or other of the aggressors. Neither Russia nor England could take and occupy the whole country alone; for instance, England could not allow Russia to take possession of the whole of Afghanistan, for in that case England could not retain possession of India without encountering a great many dangers and difficulties. And contrariwise, Russia could not sit still and allow England to take possession of the whole of Afghanistan without herself sharing in the booty.

If Afghanistan is fortunate enough to be under the rule of a shrewd, proud, strong, and far-seeing ruler, there is no reason against her rising to be a very strong kingdom, as the area and population of the country are equal to some of the great kingdoms. On the other hand, if she were to fall into the hands of such an Amir as the King of Bokhara or some of the ruling Princes of India, the ruler would give her away, by his own authority, to his neighbours, by one kind of treaty or another. And if he did not make the offer, the foreign neighbours or the petty chiefs of the country itself would force him to do so. I need not deal with this point in any detail here, because it is a fact well-known to all students interested in Eastern affairs.

Taking into consideration the matter discussed in the last paragraph, whether Afghanistan will be divided at some future date, and so lose her status as an independent kingdom, or will strengthen herself 
sufficiently to be in a position to protect herself, I must deal with both these points fully, and give my advice to my nation.

In this section I shall suggest and advise how, in my opinion, Afghanistan may be consolidated into a strong and independent kingdom. A second point will be the steps which ought to be taken to prevent its being divided by its neighbours; this point will be specially dealt with in the second section, which concerns the Foreign Policy.

Afghanistan is a country which resembles a rich soil, capable of producing all sorts of flowers and fruits if placed under the superintendence of a good gardener; I mean, under the administratiou of a wise governor. For those countries which do not possess the products and means required to make them flourish are like a barren soil, which, notwithstanding the painstaking of the gardener, yields very few flowers and fruits. But Afghanistan possesses a great many sources of riches, strength, and prosperity; I will enumerate a few.

(1) Minerals.-The country is full of mines of the richest and most varied description, namely, rubies, topaz, lapis lazuli, gold, silver, lead, copper, iron, and coal; some of which, according to the reports of European geologists, are said to be the largest mines in the world. These mines most certainly are all capable of yielding splendidly, and paying the expense of working. But these precious stones and valuable mines, so long as they are not worked properly, are like hidden treasure-to the mind of a person who does not know anything about jewels, a brilliant diamond and a crystal are equal. 
(2) Commerce. - The sources and products of Afghan commerce are numerous : in addition to large and productive coal and iron mines, like those which are called the black diamonds of England, and which have had a great part in making England what she is to-day, there are plentiful waterfalls available for driving machinery, and so fostering industries.

(3) People.-The people, both men and women, are very brave, intellectual, fond of learning and education; lovers of freedom and independence, physically strong and healthy, and free from the vices of intoxication and gambling. They are very ready to adopt modern reforms and education, and are free from silly and needless scruples and superstitions or prejudices against foreigners. They are not like Indians, who, notwithstanding the fact of being under British rule for over a century, are still strangers to European ideas, and think it is a sin to wear coats and trousers and boots like Europeans, but continue to wear their old slippers, in which they can scarcely walk, and to keep the straps of their trousers hanging down to their ankles. Afghans, on the contrary, in this short period, are so vastly changed that they are smartly dressed like their brethren the Turks and other European races; and they are ready to associate with foreign men and women, and try to learn everything that they can from them.

(4) National Debt.-The country and Government of Afghanistan has no National Debt, neither has it any war indemnities to pay; it does not, therefore, labour under the difficulties which those Governments 
have to face who are burdened with a national debt, or with the payment of war indemnities to their neighbours. At any moment when they want to put a check on the war preparations or progress of their rivals, these neighbours put forward their claims to have their debts paid, arguing that "You must pay our debts before you spend money for other purposes, and before you buy any further war materials." Luckily, there is no such obstacle in the way of Afghanistan; in fact, there are no foreign ambassadors to intrigue in the affairs of my kingdom, and there are no treaties of International rights to warrant foreign Powers in interfering. Furthermore, there are no authorities given to any of the neighbouring Governments to demand concessions of railways, etc. Neither is there any English Resident with power to ask the ruling Princes, as in India, "How many cakes do you eat for breakfast?" or to dictate to them the administration of their own private affairs as well as that of the affairs of state.

(5) Neighbours.-On both sides of Afghanistan there are powerful neighbours, namely, England and Russia. Though these neighbours are the cause of much anxiety to Afghanistan yet, as they are pulling against each other, they are no less an advantage and protection for Afghanistan than a danger. Indeed, a great deal of the safety of the Afghan Government depends upon the fact that neither of these neighbours can bear to allow the other to annex an inch of Afghan territory. More than that, too, in my opinion and belief, both these strong neighbours do not think it worth their while to entangle themselves 
in a war with Afghanistan. On the contrary, they think it is to their advantage that Afghanistan should be left alone. But this is a point which will be fully discussed hereafter.

(6) Religion.-Another great secret and cause of the strength of the Afghan Government is that the people have all one religion-that of Islam. There are no people of other religions inhabiting Afghanistan in large numbers, as in the case of the Greeks and Armenians in Turkey, whom the foreign Powers could instigate to fight against their ruler. The people of Afghanistan have such strong prejudices against being ruled by a sovereign of any other religion but their own, that they look upon the kings of all other faiths as infidels; and men and women take up arms to fight for their faith, believing that every one who is killed in fighting against infidels will go straight to Paradise. It is therefore a constant prayer of every man and woman in Afghanistan: "O Allah, give me the death of a Shahid" (martyr). In fact, they are lovers of freedom and independence and liberty, and they will hardly submit to the rule of the kings of their own faith much less will they submit to any other.

It is quite clear that the inhabitants of districts bordering on India, like the Khyber and other frontier tribes, have not become such peaceful subjects that any one can travel through their country without a strong body-guard. The country is so hilly that the peaks of the mountains are strong, natural forts for the protection of its born warriors, so that neither does the Russian Government consider it advisable 
to attempt to cross over these hundreds of miles of inaccessible mountains against the wish of the nation and their ruler, nor does the English Government think it wise to spend enormous sums of money and lose many valuable lives in such a country, which if it was ever conquered, could never be kept. The expenses of administration for a civilized Government in keeping up the army and civil service would be far heavier than the income of the State could meet.

In its present condition, Afghanistan is of no use financially, to any foreign Government, except for military service. In this last it can be of some use in helping a foreign Government which may be crossing through Afghanistan to invade or attack another neighbouring country, and might be supported by the fighting men of Afghanistan. But to keep possession of Afghanistan itself would not be a good investment for any foreign Government for at least fifty or sixty years to come, if not more, when it may have risen to such a state of progress that by the proper working of its minerals and other sources of commerce and wealth, it may have become united with the civilized world by means of railways, telegraphs, and steamers.

\section{England Anxious to see Afghanistan Safe and Strong}

Though some short-sighted English officials and some other people absorbed in the mania of a "Forward Policy" have caused misunderstandings between Great Britain and Afghanistan on several occasions, and have annexed, or tried to annex, certain Afghan tribes, calling 
them neutral or independent of Afghan rule, these people had not the sense to understand that taking and keeping under British possession all these barren lands on the borders of Afghanistan was a very unwise step, by which they burdened the exchequer of India with the heavy expense of keeping an army on the spot to maintain peace in these territories and also a Civil Service for administration. By taking upon themselves unnecessary responsibilities and heavier expenses than the income of the states will meet, they incurred greater anxieties than they were able to bear. But those short-sighted officials who are full of boasting and exaggeration of their almighty power and wisdom, believe that though God knows much, still they know more; and therefore if any body who knows better tries to give them advice, they simply ridicule him, thinking that it is impossible that any person should know half as much as themselves, the all-knowing and all-powerful missionaries of the "Forward Policy," and lovers of disputes and war. But, luckily, the English nation, its statesmen as well as its people, are better informed than these few above-mentioned all-knowing men, whose designs and desires are consequently meeting with the disapproval of British statesmen and of the public at large, who are really anxious to see Afghanistan a strong independent Government-a true ally and barrier to protect the Indian Empire of their noble Queen. I am glad to say that day by day the number of such lovers of peace and true friends of the interests of their own Government, as well as of mine, is outgrowing that of the minority, those who have been the cause of so many misunderstandings, fightings, and 
bloodsheddings, between England and Afghanistan. The British are showing that they have the interests of Afghanistan in their hearts, not only by their words, but by their actions, in trying to use all the means that they can to give help in money, in arms, in machinery, and in several other ways, for the safety, strength, and protection of Afghanistan, in which they see that the welfare of their own Indian Empire is so closely bound up.

British Ministers have not only shown their willingness to help Afghanistan, but they have gone a step further in guaranteeing the safety of my kingdom against any foreign aggressor, which enables me and my successors to devote all our attention to the progress of the internal affairs of my kingdom, leaving the anxieties of its external dangers and responsibilities to its true friends in England.

Suggestions and Advice, with Practical Hints on making Afghanistan into a Strong and Prosperous Nation.

Having given above a short account of the means that are at hand to make Afghanistan a great nation, I will proceed to give a short sketch of the modes and system by which this object is to be attained. I will not, however, go into every small matter concerning the welfare of the kingdom, but will only mention a few of the more important points which are necessary for making Afghanistan a great nation in the future.

It is easy to understand that before furnishing a house one must think of making or finding a house 
to furnish; and in case of building a house it must be surrounded by walls to keep the goods safe which are put in it; and if the house is full of holes, ditches, snakes, scorpions, etc., it is necessary to get rid of these before any one can live in it. In the same way, it was of the first and greatest importance to mark out a boundary line all around Afghanistan, so that we should first know what provinces really belonged to Afghanistan before thinking of introducing any reforms and improvements therein. Fortunately, I have succeeded in defining the boundaries of Afghanistan with the neighbouring powers, and putting an end to their gradual moving forward. This has also removed the causes of misunderstandings and put an end to all possibility of raising quarrels between my neighbours and myself or my successors on this subject, without breaking the existing treaties. This is a great basis for progress and peace for my successors, and on this score they will have no occasion to trouble themselves in communicating with their neighbours.

Taking into consideration that the boundary lines made a strong wall around the country, shaping it, as it were, into a house, it was necessary to clear that house of all the injurious scorpions existing in it, scorpions that formed a great obstacle in the way of peace and progress. To explain myself: I mean that I had to put in order all those hundreds of petty chiefs, plunderers, robbers, and cutthroats, who were the cause of everlasting trouble in Afghanistan. This necessitated breaking down the feudal and tribal system, and substituting one grand 
community under one law and under one rule. Luckily I have succeeded fully in this respect, as also in shaping Afghanistan into one united kingdom. Many of the tribal chiefs have been transformed from bitter enemies into warm friends, and I have placed them in high positions and offices under my Government. Those who did not agree to submit themselves to my rule and keep the peace have been sent out of the country; and there is not a man, from a chief to a beggar throughout the whole country of Afghanistan, who has such power, or any idea of claiming such power, as to offer resistance to my Government, or after my death, to my successors. Perhaps it would not be out of place here to ask those people who criticise my policy in demolishing or punishing some of these tribal tyrants and robbers, to glance at the history of all such empires as have risen from a feudal or blood-feud system to become civilized powers; they will then be able to judge for themselves whether these civilized empires had any fightings and bloodshed before they rose to their present system of Government or not !

During the time when I was occupied inside Afghanistan in putting it into the form of a kingdom, with the help of the sharp blade of the sword, and outside the country in shaping it as a kingdom with the sharp blade of the pen by communicating with the neighbouring Powers, I did not neglect any of the possible reforms and improvements which required to be introduced into the country. These improvements have been mentioned in their proper places, so here I shall only say that voL. II. 
not one-tenth has yet been done to make Afghanistan what it ought to be, and what it will be in the future, if improvements are made continuously. I will therefore confine myself at the present moment to giving a few hints for the future progress of the nation.

The first and most important advice that I can give to my successors and people to make Afghanistan into a great kingdom is to impress upon their minds the value of unity; unity, and unity alone, can make it into a great power. All the royal family, nobility, and people must have one mind, one interest, and one opinion, to safeguard their homes.

From my childhood up to this hour scarcely one day has passed in which a portion of the history of some country and nation has not been read by me or to me; and all this study of history brings me to one conclusion, namely, that the downfall of many kingdoms, especially those of believers in Mahomedanism in the East, has been caused by disunion and home quarrels. Islam rose to its supreme height by following that blessed motto of the great organiser of Arabia, which runs :- "All Muslims are brethren." Islam fell to pieces and lost one kingdom after another owing to disunion among them, and to not following the precept contained in that beautiful motto of "Union." I pray my successors and my nation to be of one heart and one mind in the interests of their country and homes, and to follow my footsteps concerning this policy of union. They must keep before their minds the principle by which I have been governed in collecting about my throne members of the royal family, nobility, 
and chiefs who were in exile in India, Russia and Persia, and, by so doing, turning them from being enemies into close friends. I have given a full account of this policy elsewhere, I need not therefore dwell further on it here. I sincerely hope that in the city of Kabul and in my own family and among my sons there will not be any family quarrels of a serious nature after my death. I have arranged matters during my lifetime in such a way, that all the members of my family and the Afghan people acknowledged the supremacy of my eldest son. I have carefully avoided making the mistakes made by my predecessors in dividing the kingdom and army amongst their sons, which would enable them to fight against each other in case of disunion. If, unfortunately, my sons and family should turn a deaf ear to my counsel and advice, and should fight against each other, then it will be just as well that they should be punished for their bad behaviour, and that they should suffer for not listening to my advice by losing their kingdom by the partition of Afghanistan, in which case Afghanistan would have no more existence as a nation. Should such a state of things happen, they will have themselves only to thank: as the Most Merciful Allah says: "God does not change the conditions of a people unless they change them themselves by their own actions."

But if my sons and successors are fortunate enough to continue united (which, so far as I can see, there is no reason to doubt, none of them being in a position to take up arms against that one who has absolute control over the army, treasury, and everything else), 
there is still a second difficulty to be considered, viz., the disunion of those members of the royal family who are outside Afghanistan. These members all come under two categories, namely, those who are under British protection-the British parasites; and the second, those who are under Russian protection. The first of these two classes need not be regarded in a very serious light-for the following reasons. Nearly all their followers of any importance or consequence have either arrived at Kabul, having deserted their chiefs, or are about to leave them to come to Kabul, or they are still remaining with their former chiefs in accordance with my instructions, taking their salaries from me openly or privately. The greatest hero in the world could not face an army if he was singlehanded and had no following behind him to back him up; therefore these poor creatures will follow the same course as the prince of the last royal family of Afghanistan (Suddozai), who died after growing old on British pensions in the hope of once more being placed on the throne of Kabul.

In addition to the fact that these princes are singlehanded, being without followers, the British Government knows very well, as it has a good memory, what they did in maladministration as well as in breaking faith and intriguing with Russia; and I am sure that the memory of the British officials is so good that they will bear these things in mind, and so not be compelled to learn the same lesson a second time. I doubt very much whether these princes could ever be put in power, even with the help of the British, when once Afghanistan is such 
a power as I hope it may one day become. I feel quite convinced that the British could not and would not take such a step in the face of the treaties now existing between my Government and that of Great Britain; such a breach of treaty could have only one effect, that of causing an open war with Afghanistan and with my sons and successors, which would be totally against their wish or desire. If the British are faithful to their treaties, they will never let any of the people loose who are now in their hands to give trouble to my sons. Taking all these things into consideration, there is no cause for anxiety about those who are under the guard, watch, and protection of Great Britain. Should the British officials, however, help the enemies of my family, notwithstanding the existing friendly treaties, in that case I advise my sons and successors to take the same steps which I took at the time when the Indian Government helped Shere Ali Khan against me, namely, from the first they must fight out like brave men at the cost of their lives, if need be, to expel their enemies, and in the case of their being defeated, which I hope will never happen, if they follow the policy which I am laying down for them, they must then lean back on some other power which may help them against the so-called British candidates. But I do sincerely hope and pray that such an occasion will never arise, and, so far as I can judge and so far as any man with common-sense can see into the future of Afghanistan in this respect, it is quite clear that the British interests and the safety of the Indian Empire lie in seeing Afghanistan a strong independent 
kingdom, and not in weakening it by inciting a ramfight between members of the royal family.

The other matter requiring the gravest consideration of my sons and successors is to think of the three enemies who are under Russian protection. This is the only source of real danger, though this may be either of an insignificant kind or of more importance, according to the circumstances of the time. One thing is quite certain-that there is a danger. The reasons which lead me to warn my successors are numerous. I will mention a few :-

The Russians, quite contrary to the English, want to see Afghanistan divided into pieces and very weak, if not entirely cleared out of their way to India. And, therefore, whilst it is to the advantage of the English, on the one hand, to keep the rival claimants to the throne under control, it is to the advantage of the Russians to let them loose to fight it out. They have every reason for this; firstly, because it is to their interest that Afghanistan should not exist as a barrier in their way to India ; and, in the second place, because the British showed weakness by not opposing the Russians in Afghanistan with as much strength and vigour as they ought to have done at the time when the Russians intrigued with Shere Ali Khan, breaking all their promises made to the British Empire on several other occasions. The Russians believe that if they could succeed in making trouble in Afghanistan well and good; and that if they failed, the British would never take any serious steps, and the matter would pass over after a short discussion in the House of Commons or in a few newspapers. 
Another reason for being careful in this respect is that the followers of Mahomed Ishak, who is in the hands of Russia, are still very numerous, and are quite capable of doing some mischief, whether with or without success nobody can tell. My agents there have not succeeded in winning over the followers of Ishak to the same extent that they did in India, but I hope that by firm if slow working that success will surely come. There is, however, in the face of these dangers some reason for thinking that the risk is not so great, and that I have taken exaggerated pains for the sake of precaution. For it is a well-known fact that both Ishak and his father have always been, and still are, hated by every man and woman in Afghanistan. I have not sufficient space here to give a full account of the causes of this hatred; but I may say in a few words that Azim, Ishak's father, was detested for his mischief-making, which caused all the bloodshed and fightings in our family, by setting my father and Shere Ali Khan against each other; also for his unbearable cruelties, his constant drunkenness, and numerous other bad habits; and, last and most despicable, for his cowardly nature - a thing which is hated more by the Afghans than anything else. His son, Ishak, is hated, not only for the same ill deeds as his father, but also owing to his breaking faith with me, to his disloyalty, and to his most idiotic and cowardly conduct in running away after his army had defeated my soldiers, and so leaving all those who had helped him to suffer for his weakness and cowardice. Besides this, he was never a fighting man, and there is no room for a ruler in Afghanistan who has no military merits whatever. The 
good organisation of the army which was placed under him, and which, under his bad counsel and misleading, fought against me, was no credit to him, because I had appointed over it the best and cleverest military officers in Turkestan. His son it was who took an active part in the battle, otherwise the father would not have been able to conduct the war at all. As reference has been made to his son, I may mention that his name is Ismail, and that he is about ten years older than my eldest son, and though he is a man capable of fighting, which his father is not, yet there is no possible chance of his succeeding to the Kabul throne, because he is unknown to the chiefs and people of Kabul, and they have never seen him in their lives. The Afghans, who hardly place their confidence in a man whom they personally know, are the last nation to submit to the rule of a man unknown to them, as they are far too proud and brave warriors to do so.

There is another difficulty in the way of Ishak and his son, namely, that they are at least three months' journey from Kabul, eyen should they march to Kabul with their forces without being opposed at any point on their way (which is scarcely possible or likely). Hence, any person who succeeds to the throne of Kabul will be in a position to meet them on their way, and would give them a warm reception before they could gather any large number of followers. But supposing they were supported by the Russian army, in that case it would become a question of war between Great Britain and Russia, as is very easy to understand; and this point will be dealt with in the second part of this chapter. But though I am quite sure that there is hardly any 
possibility of Ishak or his son succeeding in making trouble for my sons and successors, yet I would warn and advise them to watch my policy towards Russian candidates more keenly than towards those under the protection of the British Government.

But my son must not flatter himself that he will succeed to the throne if he does not make himself worthy of such an honour, or that after succeeding to the throne he will be able to keep it, unless he has the merits to keep it: he must therefore follow my advice and policy very keenly and strictly, otherwise it will be very difficult for him to maintain or even obtain the throne of Kabul. The first thing that he ought to do is to prove to the nation that he has a strong character, and is a self-reliant, hard-working, patriotic sovereign; for, in the case of failing in any of these three important points, he would not only lose his kingdom, but might put himself into still greater dangers. I do not mean to say that he must be so self-reliant as never to consult with any of his well-wishers, but I emphasise that no adviser or counsellor must make him into a mere mouthpiece: he must listen to all, but never follow any. He knows that every individual in the country (man or woman), from a beggar or a shopkeeper upwards, is now allowed to address a letter direct to the sovereign on any subject and on any matter that he likes to give information about; and if such information proves to be true, and in the interests of government or of any of my subjects, the informant, whether he be employed in the detective service or not, must be properly rewarded. If the report be untrue, inquiries are made whether he made it with good intentions or 
from bad motives. In the latter case he is punished. I gather my knowledge from reports given me by the nobility, courtiers, officials, detectives, and any other subjects of my country who wish to give me information, in addition to reports brought me by my spies in foreign countries, who keep watch on the daily occurrences and circumstances. These last also send me newspaper cuttings concerning Afghanistan. So that, putting all these matters together, and reviewing them in my mind, I draw my own conclusions, never acting on the advice or report of anybody at all. My sons must not follow the policy of Amir Shere Ali Khan, whose advisers kept him at war with all his brothers, one after the other, through the whole of his reign, and at the end embarrassed him in a war with Great Britain, which ended in his ruin. Nor must they follow the weak policy of Yakub Khan, who, trying to please the English, made such promises and concessions, that he was unable to carry them out. One example of this was his inability to prevent the murder of Sir Louis Cavagnari, after having invited him to the court of Kabul, for which mistake he also lost his throne. The British, too, who had placed their confidence in such a weak ruler, had to bear their share of the suffering as well. Nor must my sons follow the policy of my uncle, Azim, who, for lack of any patriotic spirit, or by doing any work at all in the administration of the kingdom, and by indulging himself in drinking and immorality, lost his throne and kingdom in the course of only a few months after I had placed him there. In like cases my son cannot help suffering in the same manner as the above-mentioned rulers of Afghanistan. 
I must mention one more point here as advice to my son, and that is, that in addition to his daily duties as a ruler, he must keep a fixed time for improving his knowledge and information, as I have done throughout my life-time. The best system is that adopted by me, namely, in the evening when he is too tired to do any work himself, he must every night employ readers to read to him books of history, geographies of foreign countries, biographies of great kings and great men, without distinction of nation or country; speeches and articles spoken or written by statesmen of all the Powers of the day; and all such articles and cuttings from the newspapers as concern Afghanistan or the countries and nations in which she is interested by their having some connection with her or with her friends or enemies.

Though in every chapter of my book some advice or instruction has been given to my son and successors, I have thought it important to give the above hints as a guide and foundation for the principles which he is to follow. I will now proceed to discuss another matter, the mode of administering and ruling Afghanistan, which ought to develop gradually but steadily, so that the kingdom may become a strong, self-governed kingdom.

The foundation stone of a Constitutional Government has been laid by me; though the machinery of Representative Government has not taken any practical shape as yet. It is necessary that every ruler should observe and consider the various modes of Government adopted in various countries, not jump at conclusions in a hurry, but apply 
the best modes of governing gradually, modifying them according to circumstances and the position of his country. In my belief, the best principle of governing was that laid down by the great lawgiver of Arabia, Mahomed, our Holy Prophet, may God bless Him. It was the system of a representative Government divided into two parties; the Muhagir and the Ansar. The Government was carried out on the principles of democracy; every member had the power of giving his vote and opinion; and the majority was to be followed. I have made the following arrangements for making Afghanistan into a Constitutional Government. There are three kinds of representatives who assemble in my court and audience for consulting with me about the supplies for war materials and various other state affairs. These three classes of people are called Sirdars (or aristocracy), Khawanin Mulki (Commons, or representatives of the people), and Mullahs (ecclesiastical heads and church representatives). The first of these take their seats in the court by hereditary right, subject to the approval of the sovereign. The second are elected from among the chiefs of the country who are chosen in the following manner. In every village or town there is one man elected by the citizens of that town who must have certain qualifications which I need not give here in detail. $\mathrm{He}$ is elected by the inhabitants of that village or town, and is called Malik or Arbab. These Maliks or Arbabs elect another man from among them, but one of greater influence and greater importance in their province or constitueney, whom they call 
their Khan (or chief). Our House of Commons is composed of these Khans. But in the matter of electing the Khans the final authority rests with the Sovereign who judges of the suitability of the election of these persons for the post of Khan by their merits, their position, their loyalty, their services or the services of their fathers: these facts are considered as well as the fact that the candidate has been already chosen by the people. The third party consists of the Khan Alum (the head of religion), the Kazis (ecclesiastical judges), Muftis (ecclesiastical heads of churches and inferior courts), and Mullahs (the priests). The last-named people are the ecclesiastical heads, and rise to the position of holding their seats in the Parliament by passing examinations in religious studies and in the laws of the country, and by serving in the religious departments.

This constitutional body has not yet attained the ability nor the education to qualify it for being entrusted with authority of any importance for giving sanction to Bills or Acts of the Government. But in time they will perhaps have such authority, and in this way the people of Afghanistan will be governed for their own safety by themselves. I must strongly urge my sons and successors never to make themselves puppets in the hands of these representatives of constitutional Government; they must always reserve to themselves the full power of organizing the army and keep it in their own hands, without admitting any right of interference by their constitutional advisers. And, further, they must keep the power of vetoing any reforms, schemes or bills 
passed and sanctioned by their Council or Durbar, or Parliament, as this body may be called.

My sons and successors should not try to introduce new reforms of any kind in such a hurry as to set the people against their ruler, and they must bear in mind that in establishing a Constitutional Government, introducing more lenient laws, and modelling education upon the system of Western universities, they must adopt all these gradually as the people become accustomed to the idea of modern innovations, so that they will not abuse the privileges and reforms given to them.

In following the advice of any foreign Power, or courtiers of our own Durbar, who may possibly be bribed by some foreign Power, my sons and successors must always keep before their minds the wise and shrewd council given by Sadi in the following lines :-

"That shrewd young boy will save the purse of sovereigns in his pocket who looks upon every passer-by as a pickpocket and robber."

To secure the crown and throne of Kabul for my son and successors from the foreign aggressors, the various claimants to the throne, and the rebels of Afghanistan, great attention must be paid to the military system of the country. Though I have dealt with this subject elsewhere, I will mention a few points for the consideration of my successor. It is of the utmost importance that the whole Afghan army should be armed with the best and most improved modern weapons. One million fighting men are more than enough for the protection of Afghanistan against any foreign aggressor. With the 
above-mentioned number of fighting men available, Afghanistan need never fear any one of the greatest empires in the world. To secure this purpose the arrangements which I am trying to make are that each gun of modern improved design ought to have 500 shells, and each magazine repeater or MartiniHenry rifle 5000 cartridges, for the time of war. This quantity of arms and ammunition ought to be sufficient for $1,000,000$ soldiers. These men I have divided into two elasses: 300,000 regular army, and 700,000 volunteers and militia; the last-named must, however, be properly trained and drilled. In addition to the war material, there should be also ready for any emergency in the stores of the country itself provisions for the food of the above-mentioned force, sufficient for three years, together with elephants, camels, horses, pack-ponies, mules and other transport animals, for the needs of the army within the dominion of Afghanistan in the possession of the transport animal hirers including the Government transport animals. It is the case with many great and rich Powers that much difficulty is experienced in getting proper transport for moving their armies from one place to another; indeed, this difficulty is greater than that of finding the men to fight, or of supplying them with arms. But, praise be to God, the Afghans are such a strong, healthy, hearty people that they can run over the mountains of their country nearly as fast as horses, carrying, at the same time, their guns, ammunition, tents, and food, for a few days, on their backs. A very limited number of transport animals is therefore re- 
quired for a considerable number of men. It would not be an exaggeration to say that 100,000 English soldiers require more transport animals than $1,000,000$ Afghans, because they require so many kinds of provision, wine, soda-water, and other luxuries. Some critics will say that though an English soldier requires the comforts of a prince, he is a splendid fighting man also; I quite agree with these critics, for I have a very great admiration for the English soldier and his merits; I am only diseussing here the pack-ponies, not the merits of the men. To supply all these arms, provisions, etc., for $1,000,000$ fighting men requires money, and I am therefore only increasing the number of my army in proportion to the increase in the income of the Afghan Government. And though the regular army, paid by the Government, has required no more than 300,000 men, as mentioned above, the Government treasury ought to be sufficient to supply for keeping 1,000,000 fighting men for at least two years, for a war that might last that time, before we could think of counting upon putting such a large number of men in the field. This is not all; it would be necessary also to keep a sufficient sum of money in the treasury to maintain the manufactories for the supply of ammunition to the army in the field, and other war materials as required. It is also necessary that iron, lead, copper, and coal should be taken out of the mines of Afghanistan itself in sufficient quantities.

The arrangements upon which $I$ have been, and am occupied, have proceeded so far that I can put this number of fighting men into the field to-day, 


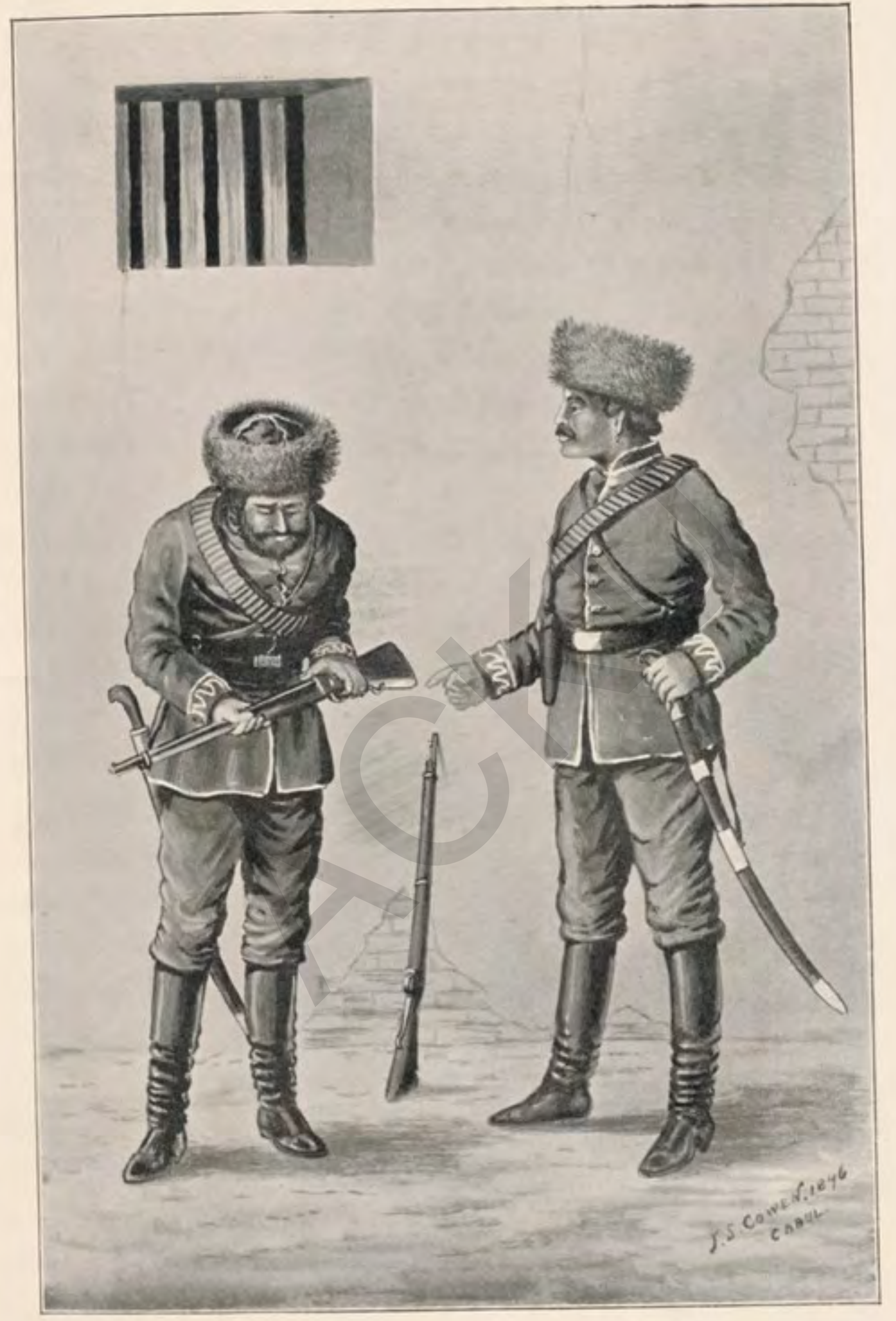

UNIFORM OF ROYAL CAVALRY. [To face p. 192. Vol. II. 

though the regular army is not large enough, the fighting men are sufficient. I can also supply the above-mentioned number of forces with artillery, guns, ammunition, and swords from within Afghanistan itself. There is also an ample store of corn for their food, and transport in the country itself.

Two things are wanted, however; one is to raise the number of the regular army and military officers to the number of 300,000 as calculated. This, I am afraid, will take a considerable time. This is not a point to be anxious about, because the Afghans have shown themselves many times to be born soldiers and warriors on occasions when, as peasants, they fought with the most brilliant, gallant, and best-trained soldiers in the world.

The main thing that is wanted, and that very badly, is money in the treasury. Though, thanks to the Almighty Allah, there was never so much ready money in the treasury of Afghanistan in the reigns of former Amirs as there is at the present time, yet it has not risen to the extent I wish it to do.

Concerning the stores for the food and provisions for the army which I have built in every large and important town in Afghanistan, I advise my son and successors to follow my example in keeping these stores filled with corn by renewing the stores every year, giving the old corn to the army at a cheaper rate than they could get it elsewhere in lieu of their pay, selling the rest, and buying fresh barley and corn to replace that sold and given away. What is sold is generally bought up by the stable-masters for the pack-ponies, horses and transport animals. My son

voL. II. 
and successors should not listen to inexperienced people who criticise my policy in keeping 48,000 horses and pack-ponies ready, and thousands of tons of corn. These critics say: "Why should the Government bear the expense of keeping so many transport animals, we can easily buy or hire them from the country at the time when necessity arises." These critics do not consider that at anxious moments there are so many things to think about and look after that there ought to be always things ready to begin with, as much time and many valuable opportunities are lost by having to make preparations afterwards. Besides, these transport animals are always employed, thereby saving as much money to the Government treasury as they cost to keep.

My sons and successors must not flatter themselves by merely looking at the large number of the army; they must keep in view that the most important point, one to be ever present to their minds, is to keep this army happy and satisfied. It is better not to have any army at all than to have a hostile and discontented one. To find out how to keep armies satisfied and contented will depend on the common-sense of their king himself; one thing is certain-they must not be drawn by conscription, and they must be paid regularly. Amir Shere Ali Khan, who took the army by force, and who did not pay them regularly, had the most discontented army in the whole kingdom, and they did not stand against the English force, which was marching towards Kabul, half so well as did the Afghan peasants. It is owing to this discontented state of the army that the fate 
of Afghan kings has often been decided in one battle, because either the army is unfit to fight, or being taken by force they are anxiously waiting to see the enemy appear, and then, without any fighting of much consequence, they fly in all directions, in order to fulfil the desire of their hearts by ruining their king, who forced them to fight against their will.

The army should be regularly paid, as I have before said, and the pay should be in cash paid monthly from the Government treasury. They must not have orders on the revenue of the country given them to collect for themselves, as was the rule in former times. A soldier whose mind is anxious about his pay and the expenses of his family cannot devote all his attention to his duties. And if a soldier goes into the country to collect the revenue debts for his monthly pay, who is to fight in his stead?

"Give money to the soldier and he will give his head in return in fighting for you; but if you keep your money away from him, he will keep his head away from you." - SADI.

Soldiers are made into brave men, properly trained for fighting, and devoted to their duties, by brave, heroic, popular officers. And a handful of good soldiers under a brave military officer can do wonders.

"One brave wolf is never afraid of a mass of sheep."-JAMI.

"The counting of numbers is of no consequence; 200 brave warriors are better than 100,000 cowards."-FrRdusI.

In selecting the military officers, in their organization and promotion, great precaution should be used. 
All the officers of the army ought to be most reliable, meritorious, devoted and loyal servants of the crown, and, if possible, belonging to good families. I do not approve of promotion by seniority, but promotion depending upon examination into their merits, their services, their bravery and administration in time of war, their good behaviour, their loyalty, and last, but not least, by their popularity among the soldiers. To my mind the last-mentioned is the most important of all.

All the officers of the army must learn the modern science of war from the books which have been translated into Persian, and are still being translated from English. My sons and successors must never forget my advice in this respect, that they must never accept offers of military officers if made by any of the Powers bordering on Afghanistan.

"Selfishness is next to madness" (Proverb).-MAHostsd.

A neighbouring Power by offering military officers from its army, under the pretence of teaching the Afghan soldiers British military tactics, might also teach them to attend to foreign interests. I hope that in a short time the Afghan people will get so much knowledge and common-sense that they will understand that the interests of their Government are identical with their own interests. They would then become as patriotic to their country as the people of many other nations are ; and might safely be sent out of their country to learn more from the European nations than would be advisable now, when they might be set against their own Government and country by the people with whom 
they associated. When they look upon the enemies of their country as their own personal enemies, then will be the time for us to send out young officers to Europe to learn more about the science of war. On their return they could teach what they had learnt themselves to their fellow-officers. At present we ought to be contented with this, that, in the first place, our people all know how to fight on their own hills, and that, in addition, the necessary books on army drill and kindred subjects have been translated into Persian, and the Afghans have studied these books thoroughly, and continue still to progress by study in acquiring more knowledge. In the days when my people had no proper rifles, no officers, did not know drill, and were only a mass of peasants and farmers, they called forth the admiration of the British soldiers against whom they fought so bravely, as well as the admiration of other Powers in the world. Now they possess the best modern arms, and being led by my generals they could fight against equal numbers of the best armies, if not against double the number in their own mountains. The students of military history are aware that in the Saidabad war, I had 8000 soldiers under my command, who defeated 70,000 of Shere Ali's army in such a manner that they fled, leaving their dead and everything behind, which defeat ended Amir Shere Ali's rule, and placed my father, who had been a prisoner in the hands of Shere Ali, on the throne of Kabul.

"Subjects are like roots and kings like trees;

Trees, $\mathrm{O}$ my children, cannot stand without their roots." - SADI.

Another piece of advice I must leave for my sons and successors is this: the existence of every Govern- 
ment and its continuance are greatly in the hands of the subjects; my sons and successors must therefore struggle day and night for the peace, happiness and welfare of their subjects. If the people are rich, the kingdom is rich-if the subjects are peaceful, the Government is at peace. If the subjects are learned and wise the statesmen and ministers of the kingdom who steer the ship of state are better fitted, being taken from the ranks of the subjects and being inspired by the people. The education of our subjects is, therefore, a matter of the very greatest importance in the future. In that future Afghanistan can never make full and complete progress unless its women are educated; the children take their first and primary lessons from their mothers, and the thoughts and ideas imbibed in childhood influence their characters and thought throughout the whole of their lives, and take a firmer hold upon the roots of their minds than any after education can ever do. It was owing to this wise policy that our Holy Prophet eommanded that women, who under no circumstances ever leave their houses without the consent and permission of their husbands, should be allowed to do so for this one purpose, that of being educated.

If the masses of the people and their wives and womenkind are educated, the statesmen who are drawn from the people and selected by the people, are sure to be better judges, better informed, better advised, and better able to carry out the administration of the kingdom, for an educated and civilized Government is unsuitable for an uncivilized people, who can only be ruled by stern, rigorous, and martial laws. In the same way uncivilized and barbarous Governments are 
quite unsuitable for learned and civilized nations. The result of such unsuitable conditions would be, that the king would lose his head, as happened in England in the case of Charles I. This calls to my mind an amusing story which I will give by way of example to illustrate my contention that the Government must be of the same class of people as the subjects they have to govern. In one of the kingdoms an astrologer informed the king that upon such-andsuch a date a heavy rain would fall, and any people who drank of the water from that rain would lose their senses and turn into lunatics. The king ordered his servants to keep a few tanks of water covered for the use of himself and his ministers, so that the maddening water should not mix with the old good water. After the rain fell, subjects who had no reservoirs of good water were bound to quench their thirst by drinking the river and canal water, and in consequence turned lunaties. The results were disastrous: all the bills and schemes introduced by the Government ministers were rejected by the people, whose brains had gone wrong. Everything that the king and his ministers said or did appeared distorted to the unhinged minds of the people. The king informed his ministers that it was quite impossible for him to carry out any measures against the wishes of his people through their parliament: it was better, therefore, that they also should drink of the same water and so bring themselves on the same level as the other lunatics. This was done, and king and ministers also became infected with the same madness; a kingdom full of lunatics could not continue 
for long, and their neighbours came and took possession of the country, turning the lunatics out of it.

A great deal of the happiness, peace, and prosperity of the subjects depends upon the justice and the laws by which they are governed. In the eyes of the law, king and beggar are equal; and my sons must not follow the example set by former Amirs, during whose reigns every official and every chief had his own laws, and there were no Courts at all. I must confess that I have not yet succeeded in completing the Courts of law, and in establishing and completing the proper system of administering justice in the Courts in that perfect and efficient manner which I should wish; there is still great room for improvement in this respect. For instance, in the beginning of my reign, when the people were rebellious, headstrong and uncivilized, my laws and punishments were very severe; but year by year, keeping pace with the education, the peaceful condition, and obedience of my subjects, I have modified many of these laws, making the punishments more lenient from time to time. My successors must continue this policy, and change and modify the laws to suit the growing advancement and progress of the nation in modern civilization. They must remember that legislative assemblies and parliaments in the various countries are only for this purpose: always to be making changes and alterations in the laws to keep pace with the progress of the world generally. I earnestly hope that my people will gradually, by the help of God, through education and the teachings of a wise Government, attain the level which will enable them to make their laws for them- 
selves, by themselves, except as regards the divine laws which govern religion, divine worship, and moral life.

The Courts of Justice that I have established are far more numerous than those existing under former Amirs, yet there is still much scope for opening further Courts, as the Government finances come to permit of more expense being incurred for this object. With more Court-room in different provinces, people would not have to travel from the places where they live in order to have their eases tried and judgments passed.

But as more cases had to be tried than the Courts could decide, and there was not enough money in the Government treasury to spend upon opening further courts to meet the demand, in order that judgment might be hastened, many cases were decided verbally, without passing through any office or making any record. The whole procedure was over in a few minutes; for the plaintiff, the defendant, and all the witnesses were brought before the judge, who, when he had heard both sides of the question personally, without having them written down, passed judgment on them on the spot; and then the next case was gone into. In this manner several judgments were given in one day. Now all eases relating to hereditaments, property, and mercantile affairs, etc., are entered in the registries, and Government records of them are kept for reference. It is necessary that clerks should be appointed to the Courts and all matters recorded in writing, so that there shall not be any misunderstandings or wrong decisions: eopies 
of the judgments must also be kept for reference, as well as for purposes of Appeal.

It is most necessary that all these changes in the Courts of law, and in the administration of justice, should be made gradually, because if a mild or lenient policy be adopted before the people can appreciate clemency, it would seem like encouraging an unruly and rebellious people, and would injure the minds of the people.

"To let housebreakers loose is to encourage housebreaking."-SADI.

For instance, the Intelligence Department, with its system of detectives and spies which has been introduced by me, is disliked by all the officials who were accustomed to take bribes, and by the chiefs who were in the habit of extorting money from their subjects, because these practices have been reported to me by the spies and detectives. I hear that these officials and chiefs speak bitterly to my sons against the officials of my Intelligence Department, so that the minds of my sons are poisoned against all the spies and detectives. But, none the less, I advise my sons and successors to keep this department always in a high state of efficiency, because it is a department which exists in all the most civilised countries: it is of vital importance for giving information to my Government upon all internal and external affairs, as well as for detecting treachery and intrigues among my enemies. There is no better means than this for learning the feelings and motives of neighbouring Powers, and for distinguishing friends from foes; by it I am 
helped in keeping up a constant watch and a careful study of all my communications with foreign Governments, and the reports upon these are kept in my office. My son should also read very carefully the book, entitled "Anwari-Suheili." This, aided by a little common-sense and precaution, will be of very great use. But to foresee the feelings and motives of all neighbouring Powers, and to realise the difference between friends and enemies, requires, in addition to the intelligence department, and a study of the above-mentioned documents and book, a great deal of thought and consideration also. All the studies in the world will not make a ripe and clever statesman. These studies, if combined with a lack of natural merit, will have the result described in the following story :-

A king placed his son under the tutorship of a most learned astrologer, and told him that he would pay him more than the parents of all his other pupils, but in return, he must teach his son more than he taught any of his other pupils. After a certain period the king took a silver ring into his hand, and asked one of the pupils the following questions:- "What is in my hand?" The boy, drawing conclusions from his study of the stars, said, "It is something round." The king's next question was: "What is the colour of it?" "White," said the boy. "What is it made of?" "Silver," was the answer; "and it is hollow in the centre." The rest could be easily guessed, that it was a silver ring, and this the boy answered to the king's satisfaction. Now came the turn of the king's son who, by the 
help of his studies, delivered the same answers, namely, that it was made of silver, and was hollow in the centre, but he had not the sense to know that an engine does not require a silver fly-wheel, and that the fly-wheel of a large engine cannot be held in a man's hand; therefore, after making his calculations, he answered that it was the fly-wheel of a traction engine that his father held in his hand. The king repeated this answer to the teacher, who replied: "The answers your son gave were correct so far as study was concerned, he only went wrong where common-sense was concerned."

For the maintenance of a kingdom, and the strength and prosperity of a nation, religion, too, is a very great factor: a nation without a religious belief would soon become demoralised, and begin to decline until it fell altogether. The Muslims are brave, because they have always been very strict in religious observances, and staunch in following the rules of their faith. I have written separate books dealing with the subject of the protection of our religion and its strict observance; I have also written upon Jihad (to fight for religion and truth, and to maintain it). Among the books and pamphlets I have written on this matter, which are published in Persian, those named Takwin din (the strong foundation of religion) and Pand namah (my advice), are of great importance, and every Muslim ought to read them. I need not say much about religion, but recommend my readers who are interested in this to read the above-mentioned ones. I advise my successors not to break down and do away with the 
system upon which I have established the Muslim faith in Afghanistan. It is this, that all the land and property, as well as money, which used to support the Mullahs, is transferred to the Government treasury, and monthly fixed salaries are paid out of the treasury to the persons employed in the religious services, e.g., Kazis, Muftis, Imams, Muezzins (those who call the faithful to prayers), and Muhtasibs (overlookers or protectors).

By adopting this system, the Muslim ecclesiastical law, and its administration, are vested in the hands of ecclesiastical officials selected and appointed by the Crown; and they hold their offices under the sole privilege of the Crown. They are therefore bound, willing or unwilling, to obey the Crown, which stops all divergences and innovations, substituting for these a general unity. Unity in Islam is the first cause or motto of its strength.

"Do not ye know what blessings the true faith of Islam has awarded to you; uniting your scattered tribes and communities into one brotherhood?"-KoRAv.

By the very wisest policy, the aim of our Holy Prophet in introducing changes into the lives of the people, was to render them very closely united together; so as to be always in close touch and association with each other. For instance, he ordered people to dine together instead of dining alone; to say their daily prayers together in a mosque instead of saying them in private; and to say their Sabbath-day prayers in the principal mosque of the town or province, which means that all the people of the town or province, though they 
do not meet each other at daily prayers, should assemble at the weekly service, as also in still larger numbers on the days of Id, which fall twice in the year. A further rule is that of going on pilgrimage to Mecea, which, naturally, brings Muslims from every part of the world, from every country, East and West, together on one day, and in one place. Some people remark that these large gatherings are a cause of disease and plagues. I am not now dealing with the question of sanitation; but I would ask how it is that the people of London and other large cities, who are more in number than the pilgrims at Mecca, do not die of plague. The reason is, that in those cities the very rules which the religion of Mahomed teaches more strictly than any other, rules tending to cleanliness and sanitation, are properly observed. The pilgrims who go to Mecca ought to obey Mahomed's laws, observing cleanliness, eating wholesome food, and drinking pure water: it is no use for Muslims to obey one part of Mahomed's commands, and to leave the rest unobeyed.

Lastly, I will say in conclusion, that if God spares me to live a few more years, or if, after my death, God spares Afghanistan from home disputes and foreign aggression, and if my sons and successors act in accordance with my advice and instructions, the Afghan nation has a very great future before it; and I hope it will be one of the great kingdoms of the world - Insha'allah (God willing). Considering the wide area of the country, the perfection of its elimate and its many sources of wealth, the numbers 
of the population, their bravery and physical strength, it is not far behind some of the great kingdoms of the world even now. The marking out of the boundary lines has put an end to the aggressions of its powerful neighbours, and the rebellions and tribal fightings have come to an end for ever, it is fervently hoped. The army, war materials, and Treasury have been set in order, and are to a certain extent perfected. Considering all these things, it must be admitted that now is the time for opening up the country for various enterprises: commerce, education, the working of the mineral wealth, the safety and encouragement of foreign capitalists, merchants, and travellers. Now is the time for cutting canals, building reservoirs for the irrigation of the land, and for collecting the water from the melted snows, so that they shall not be carried out of the country in the summer by the rivers. By keeping this water in the country, the barren lands and uncultivated districts, which are covered by most fertile soil, will be converted into valuable land and gardens. I have opened several canals, and several others are being cut; the trade in Astrakhan skins, wool, horses and sheep has considerably increased, and I have lent money out of the Government Treasury to the Afghan merchants to encourage trade, without charging any interest on such loans. (Instead of interest I charge export and import duties, which bring in more than the interest would, and leave a margin for the merchants themselves.) But it is necessary to communicate with foreign banks and bankers, and enter into arrangements that bank-notes should be issued 
to the extent of the money which is in the treasury at Afghanistan. By doing this, the money which is lying idle may be circulated several times in the year for commercial purposes. I have also sanctioned and started the system of Hundis and Bills of Exchange.

Though I am not ignorant of the advantages of free trade, yet it is not at present the time for us to adopt the policy of free trade; we are obliged to place certain restrictions on the foreign goods that we import. It is necessary that we should stop foreign goods from being brought into the country for cash as much as we can; for we must try to make in the country itself such goods and articles as are required for the country. We must also try to make more than are needed by our own people, and sell them outside our country, that our people may be enriched by the foreign money coming into Afghanistan. The greatest exports for commercial purposes and for earning money are the corn of Kataghan and Turkestan, and the products of the mines of Afghanistan. There is also much fruit which we cannot consume for ourselves; but as we have no railways, no steamers, and no telegraphs, the lack of these means of communication and transport prevents us from counting fruit as among the most paying articles of commerce.

I advise my sons and successors to continue making new roads as I have done, but to postpone the introduction of railways, those most important means and necessary factors of trade, until such time as we shall possess a sufficient army for the protection of our kingdom. But the moment 
that we see that we are strong enough to protect our country, and have organized the army as planned by me, then will be the time to make railways and introduce the telegraphic system, so as to enable us to benefit by our minerals and other sources of wealth. Then will be the time when Afghanistan (which with its beautiful climate and lovely fruits and fresh air is in the summer like paradise) will become a centre for travellers and rich people in search of health or amusement. Switzerland has the same climate as Afghanistan; but in its fruits and in the beauties of the mountains and Oriental scenery, Afghanistan would prove a greater attraction than even Switzerland to travellers. Travellers take money into a country and spend it there; they hire horses and carriages and buy goods and curios and articles of native manufacture. To encourage travellers to come to Afghanistan is one way to bring happiness and prosperity to my people.

What I wish to impress upon my sons and successors is never to give their railways or mines to any foreigners by concessions, but to make the railways and work the mines themselves, as far as they can find money for doing it. Railways ought to be opened, at first, in the interior of Afghanistan, quite away from the boundaries of the neighbouring Powers, and should run only between one town and another in the country itself. By-and-bye, however, when the country is strong enough to defend itself against all foreign aggression, then the railway lines may be joined on to those of the neighbouring countries in such a manner that the lines will be put in connection with whichever Power is voL. II. 
less hostile than the other. If it be considered necessary and advisable that concessions should be made to any foreigners, such concessions must be given in small portions and to nations whose countries do not touch the boundaries of our own dominions. For instance, to Americans, Italians, Germans, and so forth, whose possessions and countries are not in touch with Afghanistan. In my opinion, if a very large number of Europeans, such as engineers and the like, be required for the service of our Government, preference should similarly be given to the people of these countries already named. My sons and successors must hold fast to their promises, and avoid falsehood and breaking of faith, whether such promises are made to private individuals and merchants, or to Powers and Governments. For even if there be a loss in keeping a promise and an advantage in breaking it, still that temporary loss will bring more benefit to them by the credit and good reputation attendant on keeping good faith.

"Where truth stands untruth cannot stand ; truth is sure to overcome falsehood." - KoRAN.

We must keep the example of our Prophet always before the eyes of our mind. For our holy Prophet, Mahomed, even before he was announced to be a prophet and a reformer, used to be called by all the community of Arabia by the name of "Mahomed the honest." This was the true reason for his success ; for when he claimed to be a missionary of God, even his enemies admitted that there was no doubt about his honesty, and being so honest, he would never say that he was a messenger from God if it were not the truth. It was owing to his honesty that 
his employer, Khudija, who was the richest lady in Arabia, became devoted to the man who was only her servant and commercial agent, since in all his business transactions he was faithful and true. The result was that she not only placed her confidence in him, and put all her affairs and money into his hands for him to dispose of as seemed best to him, but she also placed herself at his pleasure and married him. She was his strong ally in his religious as well as in his temporal affairs, and though he was twenty-five and she a widow of fifty when he married her, he never married another woman in the twenty-five years of their married life. His truthfulness and faithfulness were so great that whenever after her death he was questioned by his devoted and beautiful young wife, Ayesha, whether he loved her more than his deceased wife, he always answered that he loved his deceased wife more. It is a favourite proverb: "Go straight, and you will find every difficulty smoothed before you," and Mahomed says: "Truth is the power of your souls, and untruth is their poison."

There is another suggestion for the progress of commerce and enrichment of the country of equal importance to the making of railways, if not indeed of greater importance. It is also one of very great political importance for keeping up the prestige of the nation and civilising it, by bringing it into touch with the world outside. I mean that Afghanistan ought to secure a footing upon the ocean, and have a port for its own steamers to load and unload at. The south-western corner of Afghanistan is very close to the corner of the Persian Gulf and the Indian Ocean, and from this only a small, plain 
plateau of ground between Kandahar, Baluchistan, Persia, and part of Karachi. Before I succeeded to the throne of Kabul, I always had a great fancy for a little piece of this sandy desert, unimportant at present, but of great value if annexed to Afghanistan in order to bring the country in touch with the ocean. But the time has not yet arrived for emphasising this point. If the friendship now existing between Great Britain and Afghanistan grows in strength and becomes properly cemented, so that England comes to trust Afghanistan thoroughly and look upon their interests as identical, and to be desirous of making Afghanistan a strong barrier between Russia and India, it would be very easy for her to give this little piece of land to the Afghan Government, in return for some services or in exchange for some other piece of country, or for some other concession, or perhaps for an annual payment of money as revenue, retaining, at the same time, her suzerainty over this piece of land. If Afghanistan had access to the ocean there is no doubt that the country would soon grow rich and prosperous, and it would never be wanting in gratitude to Great Britain for such a concession. If no favourable opportunity occurs in my lifetime to bring about this purpose, my sons and successors must always keep their eyes on this corner. They must also keep in view the idea of having small boats on the River Oxus, which will be useful for trade as well as for the protection of our north-western frontier. I hope and pray that if I do not succeed in my lifetime in the great desire for making railways, introducing telegraphs and steamers, working the mines, opening banks, and issuing bank-notes, inviting travellers and eapitalists from all 
parts of the world, and opening universities and other modern institutions in Afghanistan, my sons and successors will carry out these desires of my heart, and make Afghanistan what I desire it to become. Amen!

(2) The Foreign Policy of Afghanistan and its Diplomatic Relations with the Neighbouring Powers.

In this section, as reference will be made to the past, present, and future conditions in Afghanistan, as well as its connections with the neighbouring Powers, this object cannot be attained without giving a historical sketch of past events. I will therefore give a few outlines.

Afghans are all Mahomedans of the Suni sect, and according to the Afghan historians they are descended from the Israelites. They take their name of Afghans from the word "Afghana"; some of them being descended from the Afghana (Commander-in-Chief) of King Solomon, and others from Jeremiah the son of Saul. The Afghan people, like Scottish Highlanders and other mountainous people, are very brave, and are great warriors; they have always been fond of ruling and governing, jealous of their own liberty and independence. Various tribes and clans of Afghanistan and many of their chiefs have invaded and ruled India. For instance, Ghor, Tughlak, Ghilzai, and Durani. Indeed, whenever Afghanistan has fallen under the rule of a wise, hard-working, ambitious Muslim sovereign, the people have shown their bravery and brought victories to their country by 
conquering territory and thus bringing honour to their sovereign's flag. Not only is the credit of the victories gained by the Afghan kings due to their brave warriors, but also the victories of the great Baber, the founder and first emperor of the Mogul Empire in India, and those of Persia. A kingdom or government that can count upon the support of Afghan fighting men is to be congratulated. If she can secure the aid of these heroes to fight by her side against her enemies, the victory is certain to fall to her share. And sorrow be to that Government, however strong a military power in the world, with whose enemies the Afghans are joined in battle against her. I claim it for certain, and every person who knows anything of the history of Asia and the fighting qualities of the Afghans will agree with me, that no power can fight single-handed against another neighbouring Power which has Afghanistan as its ally. The fate of that Power which attempts to fight against the allied forces of the other neighbouring power and Afghanistan can be nothing but utter defeat, disgrace, and regret. Though Afghanistan is not so strong yet that it can elaim victory with certainty over any of its powerful neighbours single-handed, it could certainly do so aided by one or the other.

History proves that India, which has from time to time been at the mercy of the invaders from the West and Central Asia from the days of Alexander the Great to the commencement of this century, was quite safe from any attack from the West for about 200 years, in the sixteenth and seventeenth centuries, 
owing to the fact that the Mogul emperors had Afghanistan under their rule, the people of which nation supported them. After the decline of the Mogul Empire, Nadir Shah of Persia and Ahmad Shah Durani again invaded India, aided by Afghan troops.

As we are only concerned here with the period from the time of Ahmad Shah's rule in Afghanistan, I will take the historical narrative from the date of his accession, referring the readers of my book who wish for earlier particulars to other historians.

In 1747, after the death of Nadir Shah, Afghanistan had fallen into a state of anarchy out of which arose the present Durani kingdom, to which clan I am proud of belonging. Ahmad Shah, the first founder of this kingdom, was a chief of Suddozai, a clan of the Abdali tribe. In consequence of a dream of the famous Saint of Chamkani, he took the title of Shah Duri Duran (descended from the Duranis, or chamber of the chambers). My grandfather, Amir Dost Mahomed Khan, was of the Barakzai, another branch of Durani. The lines of Ahmad Shah (the first king of Suddozai Durani), and Amir Dost Mahomed Khan (the first king of Barakzai Durani) joined in this way: that Suddo and Barak, the first fathers of these two royal houses of the Durani family, were full brothers. Ahmad Shah was crowned in 1747 at Kandahar, and made Kandahar his capital. This is the year in which the history of Afghanistan made a start in having an elected king and constitutional government to govern the country. After Nadir's assassination 
in 1747 , the representatives and chiefs of the various tribes and clans of Afghanistan (named Haji Jamal Khan Barakzai, Muhbad Khan, and Sirdar Jahan Khan Populzai, Musa Jan, Ishakzai, better known by the title Dunki, Nur Mahomed Khan Ghilzai, Nasrullah Khan Nurzai, and Ahmad Khan Suddozai) held a Council at the sacred shrine of Sher Surkh Baba, in the vicinity of Kandahar, to elect a king from among themselves to rule over them; so that the country should live in peace under his rule. But, excepting Ahmad Khan, who was silent, every one of these chiefs insisted that his own claims to the throne were greater than those of the others, and that he would not submit himself to the rule of any of the others. After long dispute and discussion they were no nearer to the issue than when they started, but a holy man, named Sabir Shah, having taken an ear of wheat into his hand, placed it upon the head of Ahmad Khan, and said: "You need not quarrel, Ahmad Khan is the proper ruler for the kingdom." At this the attention of all the chiefs was turned upon Ahmad Khan; they declared that they could not find a more suitable man to be elected as their king, because his clan (Suddozai) was the weakest and smallest in number, and therefore concluded that if he did not act according to the counsel of the representatives of the country, it would be easier to dethrone him than a king from a strong tribe having a greater population. "Should he listen to our advice," they said, "we, who are the accredited representatives of the nation, will support him and give every help in the administration of the king- 
dom." Having agreed upon this, they all took pieces of green grass in their mouths as a token that they were his very cattle and beasts of burden, and throwing around their necks pieces of cloth in the shape of ropes, as a sign that they were willing to be led by him, they submitted to his rule, and gave him the powers of life and of death. Ahmad Shah being the elected king by the choice of the country, had the support of the chiefs and representatives, and he was a man of strong will, clever-headed, hardworking, and impartial. He therefore rose to the position of one of the greatest emperors that ever ruled in Asia, his dominions and empire had Mashhad or Persia on the West, and Delhi and the countries in between in India on the East. He died of cancer in the face in June 1773.

His son, Timur Mirza Shah, succeeded him, whose character was marked by indolence (the usual disease from which nearly all the Eastern kings, princes, and nobility suffer, which ends in their losing their kingdoms and fortunes). This conduct rendered him incapable of keeping together the tribes which had been conquered by his father, and the kingdom began to decline. $\mathrm{He}$ made a great mistake in appointing his sons governors of different provinces of Afghanistan, in consequence of which, upon his death in 1793, which occurred at Kabul, a struggle for the monarchy ensued between his numerous sons, which was obtained by Shah Zaman. He, after a reign of seven years, was deposed and blinded by his half brother, Shah Mahmud, who had obtained the sovereignty by the help of Wazir Fatteh Khan, 
brother of Dost Mahomed Khan, the first Amir of the present dynasty.

"This remarkable man, who occupies the most conspicuous position in the history of Afghanistan for the ensuing eighteen years, was far more deserving of the name of 'King-maker' than the celebrated Earl of Warwick, who bears the name in English history. His talents, courage, generosity, and statesmanship are equally acknowledged by all European historians who have written anything about Afghanistan, as well as by Afghans."

In September 1801, Shah Shujah, the full brother of the deposed monarch Zaman, proclaimed himself king, and marched from Peshawar on Kabul. He was, however, defeated by Wazir Fatteh Khan, and fled to the Khyber Hills. After some struggles, Shah Shujah succeeded in taking the throne in 1802, deposed and confined Mahmud in prison, and soon after conquered Kashmir also. But it must be said, without going into details, that from 1793, after Timur Shah's death, the fightings, the misfortunes, and the violent deaths of the kings and chiefs were innumerable. The breakdown of the Constitutional Government, which had been founded by Ahmad Shah, was brought about by the kings' habits of self-indulgence and intoxication, and their partiality for one person or one clan to the exclusion of the others. These characteristics of the Suddozai kings resulted in their losing the kingdom, and turning Afghanistan into a petty state after its being a vast empire before it fell into their hands.

Shah Shujah, who succeeded to the throne in 1802 , refused to make terms with Fatteh Khan, who defeated 
him in 1809 , and secured the throne for his old friend, Mahmud, once more. Shah Shujah threw himself on the protection of Runjit Singh, Rajah of the Punjab, whence he made several attempts to regain the throne but failed, because Wazir Fatteh Khan and the people were supporting Mahmud. Runjit Singh subsequently treated Shah Shujah very cruelly and imprisoned him. He took by force the Koh-i-noor diamond (Mountain of Light, now in the possession of Queen Victoria). Historians give a very impressive account, describing how one king in parting with this valuable stone turned pale and felt unhappy, while the other, who was receiving it from his hands, appeared joyful and cheered by the unexpected prize; which shows that in this world the griefs of one half its inhabitants are the pleasures of the other half. One side is delighted at having killed others in battle, and rejoices in the victory, while the other side mourns the deaths of those who are killed, and its own defeat. Shujah, after a great many difficulties, escaped with his harem from his prison, and having entered into English territory lived on English bounty.

After the defeat of Shah Shujah, Fatteh Khan ruled under the name and authority of Shah Mahmud; he took Herat from Haji Feroz for his sovereign, and repulsed an attack made on that eity by the Persians, who had demanded that tribute should be paid, and that the money should be coined in the name of the Shah of Persia. In 1818, after the most loyal services, and keeping the throne for him, the ungrateful wretch, Mahmud, following the advice of his treacherous son, Kamran, and others who were jealous of Wazir Fatteh Khan's influence and 
position, most cruelly tortured and blinded Fatteh Khan, who had twice placed him on the throne. Finally, on Fatteh Khan refusing to betray his brothers, his limbs were cut off one by one, by the orders and in the presence of the king who had been made by him, and by him alone. Thus died this remarkable man, the " Warwick of Afghanistan." His talents and gallantry gave a certain ascendency to whatever party he joined, and, further, his reputation for bravery, liberality, and nobleness of character did a great deal to help his younger brother, Dost Mahomed Khan in gaining the throne of Kabul. Fatteh Khan's father, Wazir Payandah Khan, who is called Sirdar Sar Faraz Khan, had left twenty-one able sons, namely, Wazir Fatteh Khan, Sirdars Mahomed Azim, Timur Kuli, Pur dil, Shere dil, Kohan dil, Rahim dil, Mihr dil, Ata Mahomed, Sultan Mahomed, Pir Mahomed, Said Mahomed, Amir Dost Mahomed Khan, Amir Mahomed, Mahomed Zaman, Zamar Khan, Haidar Khan, Turahbaz, Jummah, and Kheirullah.

The cruel murder of this hero and King-maker was the signal for his twenty brothers and the rest of the Duranis to take up arms against Shah Mahmud and his son Shahzadah Kamran, who had persuaded his father to kill his gallant friend. The result was that Dost Mahomed Khan, one of the youngest brothers of Fatteh Khan, defeated Mahmud's army, and made himself Amir of Afghanistan in 1826, which transferred the kingdom from the Suddozai family to the Barakzai family, and it has remained with them ever since, excepting for a short interruption caused by Shah Shujah and his supporters, the English. Shah 
Mahmud, after losing his kingdom, as a punishment for his ingratitude, died heart-broken at Herat, and his wicked son, Kamran, who was the sole cause of the murder, was killed at Herat by one of his own officials, named Wazir Yar Mahomed Khan.

It is a well-known fact that as long as a country is under the rule of a strong man who can keep control over all the chiefs and subjects of his country, whether he govern rightly or wrongly, foreign Powers cannot find an excuse for interfering with him; but the moment that a Government falls into the hands of a weak ruler or becomes disunited by internal embroilments, or that the subjects lose all their affection and fear for their sovereign, then foreign Powers seize their opportunity to put the claims of one against the other; or they interfere under the pretence of claiming for the subjects equal rights and justice. Following this rule, from the time that Afghanistan fell under the sway of weak sovereigns, and became mixed up in family quarrels and disputes-from this time the history of Afghanistan is full of instances of interference on the part of England and Russia in the affairs of the country: and efforts to keep claimants and candidates in their hands, so that they could put them forward whenever a suitable opportunity presented itself. In the past, England was near, and Russia was far away from Afghanistan, and therefore England had more to do in this respect than Russia. Now, unfortunately, Afghanistan lies between two mill-stones instead of being under one only. History shows that England interfered more with Afghanistan and made more blunders in this respect, and for this reason England 
suffered more; but Russia interfered less and suffered less. Let us hope that England, for her greater sufferings, may reap greater benefits; and I may say that if England, appreciating the friendship of Afghanistan, gained after the expense of millions of pounds and at the sacrifice of thousands of valuable lives, has learned even this single lesson, that to fight against Afghanistan, is to her disadvantage, and to be friendly is for her own interests and safety, then England will be richly repaid for her losses in the past.

After my grandfather, Dost Mahomed, succeeded to the Kabul throne, I cannot give the full account of historical events without being accused of partiality, and I will therefore quote the statements made by certain English historians, only giving as much as is necessary to explain our future policy.

"The Russians have, from very early ages, always had a desire to invade India in their heart. In 1791, the Empress Catharine had considered a scheme of invasion of India via Bokhara and Kabul. Again, in 1800, the Emperor Paul of Russia, and Napoleon, then First Consul of France, plotted out a plan to make a joint expedition against India. In 1807 the Emperor Napoleon and Alexander thought of the invasion once more, this time to be aided by the Shah of Persia: soon after this, however, the emperors quarrelled between themselves, which postponed their designs. In 1837 Russia and Persia joined together to attack Herat, with a view to invading India, but failed in conquering the strong fort of Herat. In 1855 again, Russia matured its schemes for the invasion of India, but, owing to European complications, could not carry out her schemes. The Russians also tried to turn Dost Mahomed Khan to their side but failed. From 1872 till 1878 they made a 
public plot with Amir Shere Ali Khan against the English." "Abstract of Curzon's Russia in Central Asia," pp. 323-330.

"Dost Mahomed, the brother of Fatteh Khan, became king of Kabul, and had the reputation of a just, enlightened ruler. Kamran seized Herat. Kandahar, after passing through various hands, became subject to the Sirdars. The Amirs of Scinde became independent, and Runjeet Singh took advantage of the general confusion to make encroachments on the disordered monarchy.

Things continued thus until it was forced on the Indian Government that Russian influence was gaining ground in Central Asia; and matters were brought to their height by the Russians besieging Herat in 1837. Endeavours were then made to detach Dost Mahomed from the interests of Russia and Persia. He declared himself willing to embrace the British Alliance if the British would protect him from the encroachments of Runjeet Singh, who had seized Peshawur; otherwise he must throw himself on the protection of Persia. In an evil hour it was determined that our relations with Runjeet Singh did not permit of our interfering with him; but still less could we allow Dost Mahomed to form an alliance with Persia; and the only remaining course was to dethrone him, and to reinstate Shah Shujah, who had been twenty-eight years a fugitive, in order to secure, as it was fondly imagined, our influence throughout Central Asia.

Accordingly, in 1838 and 1839, Sir John Keane's force marched through the Dooraunee Empire, meeting with little opposition, but at Ghuznee Dost Mahomed surrendered to Sir W. H. M'Naughton; Shah Shujah returned; all appeared prosperous; Shah's troops were raised; Dooraunee orders were distributed; Sir John Keane was raised to the peerage; addresses and congratulations were presented on all sides. Alas! how little the political nniverse-how little the world at large dreamt of the mine over which they were standing. In the beginning of November, 1841, it exploded, and the assassina- 
tion of the British Envoy, the total destruction of a large British force, including Her Majesty's 44th regiment and several corps of Indian troops, the seizure of all guns, the capture of officers and ladies-a catastrophe, in short, almost unequalled in our annals, fearfully dispelled the vision of Afghanistan tranquil and of British influence established throughout Central Asia. In the spring of the year, our protege, Shah Shujah Ool Moolk, was murdered by a party of Baurikzyes, while proceeding to his camp at Bootkhak, a miserable end to a troublous life.

The manner in which we were extricated from the ruins of our schemes of unjust aggression has been as merciful and unexpected as our punishment was sudden and appalling. God grant that His undeserved goodness may not be overlooked amidst our present triumphs, as it was totally forgotten amidst those of 1839 , and may our rulers have grace to remember that it is righteousness, not conquest, that exalteth a nation; and that the sin of covetousness, as well as every other, is a reproach to any people."-Allen's "Diary of a March through Scinde and Affghanistan" (1843, pp. 13 et seqq.).

"Caubul, Candahar and Peshawer, with the districts round these cities, were held by different brothers, who soon fell out among themselves. The Dooraunees paid a partial obedience to the ruler of Candahar or Heraut according to the situation of their lands. The other tribes remained independent. During the decay of the Dooraunee monarchy, Runjeet Sing was perfecting the discipline of his army by means of European officers. This circumstance which would have made him formidable to the Indian possessions of the Afghauns, even if that nation had been united, rendered him irresistible to their distracted government and denuded frontier. He took Cashmeer, Moultaun, Leia, Upper Sind, and the nearest part of Damaun, reduced the tribes south of Cashmeer into dependence, and he subsequently took advantage of a quarrel between the chief of 
Caubul and his brother at Peshawer, accompanied by a successful expedition of Shauh Shujah against Candahar, to make a conquest of Peshawer itself and all the plain country to the Indus. The Ameers of Sind also seized on Shikarpoor, Bulkh threw off its nominal dependence, and the Prince of Belochistaun retained his in name only. Dost Mahommed, the Sirdar of Caubul, has the reputation of a just and enlightened ruler. Both he and his half-brother at Candahar are inimical to Caumraun, who has succeeded, by his father's death, to the possession of Heraut and the claims of the house of the Suddozye. The city of Peshawer has suffered greatly during these wars and revolutions, but there does not appear to be any decline in the rest of the country.

Besides the expedition in which he gained temporary possession of Candahar, Shauh Shujah has been engaged in other enterprizes in different parts of his dominions: but is now again an exile at the British station of Loodeana. In the interval he has gone through many romantic adventures of which he has written a narrative. He was at one time perfidiously seized and barbarously treated by Runjeet Sing, whose object was to extort from him the famous diamond called the Cohi Noor. These events, and his deliverance by the spirit and talents of his Queen, form an interesting portion of the summary of recent events in Afghaunistaun, by Sir A. Burnes, from which, and the fuller narrative of $\mathrm{Mr}$ Conolly, the substance of this note has been extracted. The most natural consequence of all these misfortunes would have been the subjugation of the Afghan's part of Khorassaun by Persia, but although repeated attempts have been made to take Heraut, and though the King of Persia has a regular army, disciplined by European officers, no impression has yet been made in that quarter. Caumraun himself seems to rival his father in feebleness and debauchery, but his power is upheld by the vigour and courage of Yaur Mahommed Khaun, his vizeer. . . . It is now a year since Heraut has been besieged by the King of Persia, and although by the last accounts he had just voL. II. 
failed, with heavy loss [the loss is stated to be 11 colonels, 45 other officers, and 1750 disciplined soldiers], in an attempt to storm, yet if the chiefs of Candahar and Caubul should be induced to join the common enemy, it is possible that his perseverance may still be rewarded by the conquest of the bulwark of the Dooraunee country. Such an event would produce a serious change in the prospects of our Indian Empire, and might possibly not be without influence on the politics of Europe." (Oct. 1838), "Elphinstone's account of the Kingdom of Caubul."

"Since it was the British complications with Persia which mainly furnished what pretext there was for the invasion of Afghanistan by an Anglo-Indian army in 1839, some brief recital is necessary of the relations between Great Britain and Persia, prior to that aggression.

By a treaty concluded between England and Persia in 1814, the former state bound itself, in ease of the invasion of Persia by any European nation, to aid the Shah either with troops from India, or by the payment of an annual subsidy in support of his war expenses. It was a dangerous engagement, even with the caveat rendering the undertaking inoperative if such invasion should be provoked by Persia. During the fierce struggle of 1825-7 between Abbas Meerza and the Russian General, Paskevitch, England refrained from supporting Persia either with men or with money, and when prostrate, Persia was in financial extremities because of the war indemnity which the treaty of Turkmanchai imposed upon her, England took advantage of her needs, by purchasing the cancellation of the inconvenient obligation at the cheap cost of about $£ 300,000$. It was the natural result of this transaction that English influence with the Persian Court should sensibly decline, and it was not less natural that in conscious weakness Persia should fall under the domination of Russian influence.

Fatteh Ali, the old Shah of Persia, died in 1834, and was succeeded by his grandson, Prince Mahomed Meerza, a young 
man who inherited much of the ambition of his gallant father, Abbas Meerza. His especial aspiration, industriously stimulated by his Russian advisers, urged him to the enterprise of conquering the independent principality of Herat, on the western border of Afghanistan. Herat was the only remnant of Afghan territory that still remained to a member of the legitimate royal house. Its ruler was Shah Kamran, son of that Mahmoud Shah who, after ousting his brother, Shah Shujah, from the throne of Kabul, had himself been driven from that elevation, and had retired to the minor principality of Herat. The young Shah of Persia was not destitute of justification for his designs on Herat. That this was so, was frankly admitted by $\mathrm{Mr}$ Ellis, the British envoy to his Court, who wrote to his Government that the Shah had fair claim to the sovereignty of Afghanistan as far as Ghuznee, and that Kamran's conduct in occupying part of the Persian province of Seistan had given the Shah 'a full justification for commencing hostilities against Herat.'

The serious phase of the situation for England and India was that Russian influence was behind Persia in this hostile action against Herat. Mr Ellis pointed out that in the then existing state of relations between Persia and Russia, the progress of the former in Afghanistan was tantamount to the advancement of the latter. But, unfortunately, there remained valid an article in the treaty of 1814 to the effect that, in case of war between the Afghans and the Persians, the English Government should not interfere with either party unless when called on by both to mediate. In vain did Ellis and his successor M'Neill remonstrate with the Persian monarch against the Herat expedition. An appeal to St Petersburg on the part of Great Britain produced merely an evasive reply. How diplomatic disquietude had become intensified may be inferred from this, that whereas in April 1836 Ellis wrote of Persia as a Russian first parallel of attack against India, in the early part of 1837, Lord Auckland, then Governor-General of India, directed M'Neill to urge the Shah to abandon his 
enterprise, on the ground that he (the Governor-General) 'must view with umbrage and displeasure, schemes of interference and conquest on our western frontier.'

The Shah, unmoved by the representations of the British envoy, marched on Herat, and the siege was opened on 23rd November 1837. . . . M'Neill effected nothing definite during a long stay in the Persian camp before Herat, the counteracting influence of the Russian envoy being too strong with the Shah, and the British representative, weary of continual slights, at length quitted the Persian camp, completely foiled. After six days' bombardment, the Persians and their Russian auxiliaries delivered an assault in force on 23rd June 1838. It failed with heavy loss, and the dispirited Shah determined on raising the siege. His resolution was quickened by the arrival of Colonel Stoddart in his camp, with the information that a military force from Bombay, supported by ships of war, had landed on the island of Karrack in the Persian Gulf, and with the peremptory ultimatum to the Shah that he must retire from Herat at once. Lord Palmerston in ordering this diversion in the Gulf had thought himself justified by circumstances in overriding the clear and precise terms of an article in a treaty to which England had, on several occasions, engaged to adhere. As for the Shah, he appears to have been relieved by the ultimatum. On the 9th September he mounted his horse and rode away from Herat. The siege had lasted nine and a half months. To-day, half a century after Simonich the Russian envoy followed Mahomed Shah from battered but unconquered Herat, that city is still an Afghan place of arms.

"Shah Shujah-ool Moolk, a grandson of the illustrious Ahmed Shah, reigned in Afghanistan from 1803 till 1809. . . After his downfall, Afghanistan for many years was a prey to anarchy. At length, in 1826, Dost Mahomed succeeded in making himself supreme at Kabul, and this masterful man thenceforward held sway during the three years of the British occupation.... After years of varied fortunes, the young 
warrior had worsted all his enemies, and in 1826 he became the ruler of Kabul. . . . He had a real regard for the English, and his loyalty to us was broken only by his armed support of the Sikhs in the second Punjab war.

The fallen Shah Shujah, from his asylum at Loodianah, was continually intriguing for his restoration. His schemes were long inoperative, and it was not until 1832 that certain arrangements were entered into between him and the Maharajah Runjeet Singh. To an application on Shah Shujah's part for countenance and pecuniary aid, the Anglo-Indian Government replied that to afford him assistance would be inconsistent with the policy of neutrality which the Government had imposed on itself ; but it unwisely contributed financially toward his undertaking by granting him four months' pension in advance. Sixteen thousand rupees formed a scant war fund with which to attempt the recovery of a throne, but the Shah started on his errand in February 1833. After a successful contest with the Ameers of Scinde, he marched on Kandahar and besieged that fortress. Kandahar was in extremity when Dost Mahomed, hurrying from Kabul, relieved it; and then joining forces with its defenders, he defeated and routed Shah Shujah, who fled precipitately, leaving behind him his artillery and camp equipage. During Dost Mahomed's absence in the south, Runjeet Singh's troops crossed the Attock, occupied the Afghan province of Peshawur, and drove the Afghans into the Khyber Pass. No subsequent efforts on Dost Mahomed's part availed to expel the Sikhs from Peshawur, and in suspicion of British connivance with Runjeet Singh's successful aggression, he took into consideration the policy of fortifying himself by a counter alliance with Persia. As for Shah Shujah, he had crept back to his refuge at Loodianah.

Lord Auckland succeeded Lord William Bentinck as GovernorGeneral of India in Mareh 1836. In reply to Dost Mahomed's letter of congratulation, his Lordship wrote:- 'You are aware that it is not the practice for the British Government to interfere with the affairs of other independent States'; an abstention 
which Lord Auckland was soon to violate. He had brought from England the feeling of disquietude in regard to the designs of Persia and Russia, which the communications of our Envoy in Persia had fostered in the home Government, but it would appear that he was wholly undecided what line of action to pursue. 'Swayed,' says Durand, 'by the vague apprehensions of a remote danger entertained by others rather than himself,' he despatched to Afghanistan Captain Burnes on a nominally commercial mission, which, in fact, was one of political discovery, but without definite instructions. Burnes . . reached Kabul in September 1837, two months before the Persian army began the siege of Herat. $\mathrm{He}$ had a strong prepossession in favour of Dost Mahomed, whose guest he had already been in 1832 , and the policy he favoured was not the restoration of the legitimate dynasty in the person of Shah Shujah, but the attachment of Dost Mahomed to British interests by strengthening his throne and affording him British countenance.

Burnes sanguinely believed that he had arrived at Kabul in the nick of time, for an envoy from the Shah of Persia was already at Kandahar; bearing presents and assurances of support. Dost Mahomed made no concealment to Burnes of his approaches to Persia and Russia, in despair of British good offices, and being hungry for assistance from any source to meet the encroachments of the Sikhs. But he professed himself ready to abandon his negotiations with the Western Powers if he were given reason to expect countenance and assistance at the hands of the Anglo-Indian Government. Burnes communicated to his Government those friendly proposals, supporting them by his own strong representations. Meanwhile, carried away by enthusiasm, he exceeded his powers by making efforts to dissuade the Kandahar ehiefs from the Persian alliance, and by offering to support them with money to enable them to make head against the offensive by which Persia would probably seek to revenge the rejection of her overtures. For this unauthorised excess of zeal, Burnes 
was severely reprimanded by his Government, and was directed to retract his offers to the Kandahar chiefs. The situation of Burnes in relation to Dost Mahomed was presently complicated by the arrival at Kabul of a Russian officer claiming to be an envoy from the Tsar, whose credentials, however, were regarded as dubious, and who, if that circumstance has the least weight, was on his return to Russia utterly repudiated by Count Nesselrode. Dost Mahomed took small account of this emissary, continuing to assure Burnes that he cared for no connection except with the English, and Burnes professed to his Government his fullest confidence in the sincerity of those declarations. But the tone of Lord Auckland's reply addressed to the Kabul ruler, was so dictatorial and supercilious as to indicate the writer's intention that it should give offence. It had the effect, and Burnes' mission at once became hopeless. Yet, as a last resort, Dost Mahomed lowered his pride so far as to write to the Governor-General imploring him 'to remedy the grievances of the Afghans, and afford them some little encouragement and power.' The pathetic representation had no effect. The Russian envoy, who was profuse in his promises of everything which Dost Mahomed was most anxious to obtain, was received into favour and treated with distinction, and on his return journey he effected a treaty with the Kandahar chiefs which was presently ratified by the Russian minister at the Persian Court. Burnes, fallen into discredit at Kabul, quitted that place in August, 1838.

Burnes had failed because after he had quitted India for Kabul, Lord Auckland's policy had been gradually altering. Lord Auckland had landed in India in the character of a man of peace. That, so late as April 1837, he had no design of obstructing the existing situation in Afghanistan, is proved by his written statement of that date, that 'the British Government had resolved decidedly to discourage the prosecution by the ex-king Shah Shujah-ool-Mulk, so long as he may remain under our protection, of further schemes of hostility against the chiefs now in power in Kabul and Kandahar.' Yet 
in the following June he concluded a treaty which sent Shah Shujah to Kabul, escorted by British bayonets. Of this inconsistency no explanation presents itself. It was a far cry from our frontier on the Sutlej to Herat on the confines of Central Asia $-\mathrm{a}$ distance of more than 1200 miles, over some of the most arduous marching ground in the known world. No doubt the Anglo-Indian Government was justified in being somewhat concerned by the facts that a Persian army, backed by Russian volunteers and Russian roubles, was besieging Herat, and that Persian and Russian emissaries were at work in Afghanistan. Both phenomena were rather of the 'bogey' character; how much so to-day, shows when the Afghan frontier is still beyond Herat, and when a descendant of Dost Mahomed still sits in the Kabul musnid. But neither England nor India scrupled to make the Karrack counterthreat, which arrested the siege of Herat; and the obvious policy as regarded Afghanistan was to watch the results of the intrigues which were on foot, to ignore them should they come to nothing as was probable, to counteract them by familiar methods if serious consequences should seem impending. Our alliance with Runjeet Singh was solid, and the quarrel between Dost Mahomed and him concerning the Peshawur province was notoriously easy of arrangement.

On whose memory rests the dark shadow of responsibility for the first Afghan war? The late Lord Broughton, who, when Sir John Hobhouse was President of the Board of Control from 1835 to 1841 , declared before a House of Commons Committee in 1851, "The Afghan war was done by myself; entirely without the privity of the Board of Directors.' The meaning of that declaration of course was, that it was the British Government of the day which was responsible, acting through its member charged with the control of Indian affairs; and further, that the directorate of the East Indian Company was accorded no voice in the matter. But this utterance was materially qualified by Sir J. C. Hobhouse's statement in the House of Commons in 1842, 
that his despatch indicating the policy to be adopted, and that written by Lord Auckland, informing him that the expedition had already been undertaken, had crossed each other on the way.

... The scheme of action embodied in the treaty which in the early summer of 1838 was concluded between the AngloIndian Government, Runjeet Singh, and Shah Shujah, was that Shah Shujah, with a force officered from an Indian army and paid by British money, possessing also the good-will and support of the Maharajah of the Punjab, should attempt the recovery of his throne without any stiffening of British bayonets at his back. Then it was urged, and the representation was indeed accepted, that the Shah would need the buttress afforded by English troops, and that a couple of regiments only would suffice to afford this prestige. But Sir Harry Fane, the Commander-in-Chief, judiciously interposed his veto on the despatch of a handful of British soldiers on so distant and hazardous an expedition. Finally, the Governor-General, committed already to a mistaken line of policy, and urged forward by those about him, took the unfortunate resolution to gather together an Anglo-Indian army, and to send it, with the ill-omened Shah Shujah on its shoulders, into the unknown and distant wilds of Afghanistan. This action determined on, it was in accordance with the Anglo-Indian fitness of things that the Governor-General should promulgate a justificatory manifesto. Of this composition it is unnecessary to say more than to quote Durand's observation that in it "the words "justice and necessity" were applied in a manner for which there is fortunately no precedent in the English language '; and Sir Henry Edwardes' not less trenchant comment that 'the views and conduct of Dost Mahomed were misrepresented with a hardihood which a Russian statesman might have envied.

'All men whose experience gave weight to their words opposed this preposterous enterprise.' Mr Elphinstone, who had been the head of a Mission to Kabul thirty years earlier, 
held that 'if an army was sent up the passes, and if we could feed it, no doubt we might take Kabul and send up Shah Shujah, but it was hopeless to maintain him in a poor, cold strong and remote country, among so turbulent a people.' Lord William Bentinck, Lord Auckland's predecessor, denounced the project as an act of incredible folly. Marquis Wellesley regarded 'this wild expedition into a distant region of rocks and deserts, of sands and ice and snow, as an act of infatuation.' The Duke of Wellington pronounced with prophetic sagacity that the consequence of once crossing the Indus to settle a Government in Afghanistan would be a perennial march into that country." (Extract from "The Afghan Wars," by Archibald Forbes, pp. 1-13.)

"(The Simla Manifesto:) 'We had no hand in depriving the Shah of his kingdom, whereas we ejected the Dost, who had never offended us, in support of our policy, of which he was the victim."” (Ibid., p. 48.)

"Burnes and Macnaghten had met their fate because they had gone to Kabul the supporters of a detested intruder and the unwelcome representatives of a hated power." (Ibid., p. 187.)

I cannot, however, write the full details of the history of Afghanistan or its wars with Great Britain : this would require a separate book in itself; and the subject has already been fully gone into by many English writers of great authority. But I must say that for no fault of Dost Mahomed Khan whatever, and against the instructions and advice of Burnes, Macnaghten, and all those who knew better, the Viceroy and the Indian Government deposed and imprisoned Amir Dost Mahomed Khan, and sent him to India as a prisoner in November, 1840. The result of this unjust poliey was that a general 
massacre of the English people at Kabul took place; followed by the murder of Shah Shujah and by Amir Dost Mahomed's being handed over to the Afghans: he succeeded to the throne of Kabul in 1843 , and ruled until the 9th June 1863. He died a natural death at Herat, where his body lies.

After his death his eldest son, viz, my father, Amir Afzul Khan, being absent, Shere Ali Khan took the title of the Amirship. What followed upon this has been fully dealt with in previous chapters of my book; but this remains to be added, that during his reign the British Government, or rather, the Indian Government, blundered in allowing and eneouraging him to communicate with the Russian Government, afterwards blaming him for doing so. On the other hand, Shere Ali Khan is also not free from blame for speaking rudely about Queen Victoria in public Durbar, and intriguing with the Russian Government against the English during the whole time he was pretending to be a true friend to Great Britain. This double mistake of both Governments (of India and Shere Ali's) caused the Second Afghan War, in which Shere Ali Khan's forces were defeated, and he ran away to Russia to bring Russian arms to support him. The Russian Government was too far away to be in a position to mass its army on the Afghan frontier, and, finally, Amir Shere Ali Khan died broken-hearted, and crippled by gout, on his way to Russia. Then the Indian Government made a third blunder, which caused the murder of Sir Louis Cavagnari and his party. After the British complaint of the treatment they had received at the 
hands of Amir Shere Ali Khan, they now entered into a treaty with his son Yakub. But worst of all, they sent Sir Louis Cavagnari with a handful of Englishmen to Kabul without sufficient body-guard to defend him, having confidence in Yakub's power to protect them. This they did, knowing what had been the fate of Macnaghten and Burnes, and not knowing whether Yakub was strong enough to ensure the safety of the English, nor whether Yakub had the consent of the representatives of the country to the admission of Cavagnari and his companions. This ended in Yakub's imprisonment and a general rising throughout the whole country, with much bloodshed and the expenditure of money for the Second Afghan War. Then I eame away from Russia, and succeeded to the throne of Kabul, and I sent the British army safely out of Afghanistan.

Having given a short outline of the British relations with Afghanistan, I will now proceed to comment on this matter, and to give my views on the future poliey of my country, so far as concerns England and Russia. Before commencing, I will call attention to the map attached to this book, and a little study of historical events bearing with the relations of England and Afghanistan in the past, which show clearly that at the time of the weakness of the kingdom under my grandfather, Dost Mahomed Khan, the British took advantage of this circumstance to cut certain states from the borders of Afghanistan, and bring them under their protection. Again in the days of Amir Shere Ali Khan and Yakub, they took from Afghanistan the Kuram 
Valley, the Khyber Pass, a portion of Pishin, and certain other places. During my reign, notwithstanding my strong resistance, Lord Lansdowne's Government chased my officials out of Bulund Khel, Waziristan, and other places, with the threat of English bayonets being turned against me, and the new Chaman railway station was built in my territory without my permission or the permission of my people. Though Sir Mortimer Durand's Mission reconciled matters by giving me some sort of compensation, and I am quite contented and satisfied that I have gained more than I have lost by British friendship, I merely mention these facts to show the readers of my book that though England does not want any piece of Afghanistan, still she never loses a chance of getting one-and this friend has taken more than Russia has!

After the outline of historical facts given above, taken from the writings of some English historians and statesmen, I now give my opinions in the form of advice to my successors and nation. I do not want to enter into a controversy in order to prove that my statements are wiser than those made by some of the foreign writers, and I think that to give out everything that is in my heart to the world generally would be unwise as well as impolitic. I will merely give a few hints, and leave the rest for my successors to guess.

"A hint is sufficient for a sensible man to draw his own conclusions."

On the opening of Parliaments and other Councils in foreign countries, it is customary for the Sovereign 
to state in the Speech from the Throne:- "The relations of my Government with other Foreign Powers are most cordial and friendly," though, perhaps, all the while they are repeating these words they know that they hate some of them in their hearts with thousands of hatreds. This is, however, diplomacy!

I am afraid that if I were to follow the same example, and repeat the same sort of ambiguous phrases, my nation and successors would not have the cleverness and ability to read between the lines, and would, consequently, fall into a trap. I must therefore say a few plain words.

Praise be to Allah! who is the commander of all hearts, turning the hearts of enemies into those of friends when He pleases: the relations of $m y$ Government with its neighbouring Powers, i.e. England, Russia, Persia, and China, are satisfactory and friendly; there is no cause for enmity, and no fear of hostilities breaking out at the present time. Neither of the friends has any documentary or other proof by which it can accuse the Government of Afghanistan of having broken its faith and friendship; though I am not responsible for the rumours which circulate from time to time. Neither is there any excuse for a hostile power to accuse Afghanistan of having provoked her anger. (Though I do not admit that any Government is hostile towards my Government). From the day of my accession to the throne I have never shown any fear or timidity, neither have I humiliated myself and my nation by flattery towards any of my neighbours; nor have 
I taken any unnecessary steps to show hostility or dislike to any other Power, by exhibiting partiality to one rather than the other. I have given no promises to my neighbours that were beyond my power of carrying out, as my predecessors had done. I have very strictly followed the advice, and walked in the footsteps of our Blessed Prophet, may Allah shower His rewards upon his holy soul I The best course to follow is the middle course, and to avoid extremes. If any Government, or officials of a Government, have treated me courteously, I have shown them equal courtesy in return: if I have been treated rudely and discourteously, I have not remained far behind in paying them back! I have, at the same time, been most careful to observe a dignified contempt without going beyond limits, or showing more discourtesy than I was justified in doing.

"To be too gentle makes a man lose his dignity ; as the bow does not become subject to the arrow until it gives way by bending."-JAMr.

I do not wish to name any one Power in particular, but I give a hint for the information of my people that they must always try to know the difference between the characters of various Powers: some of them resemble a leech that goes on sucking the blood till a man dies without feeling any pain, while others are like a pinch which is very painful but does not kill-like a wasp of non-poisonous nature, where there is great pain but no danger of death. Some Powers take new countries by the force of their strength and victories; others take them by treachery, 
fraud, and stirring up home quarrels between chiefs of the country, themselves keeping behind the curtain, and benefiting themselves at the expense of the folly of others. Such Powers are more difficult to deal with, and one ought to be more careful in dealing with them than with the Powers that attack openly. This is a very complicated and delicate point, and I advise my people to be very watchful in all their dealings:- "Forewarned is forearmed," and "Knowledge is power." My people must not be disunited, lest they fall victims to the treachery of their neighbours, by giving them chances and opportunities of being benefited by our dissensions.

Before proceeding any further, I must say that I am fully aware that people who do not know me well call me cruel, a lover of money and greed, and a man of most suspicious nature. My answers to these accusations have been given by many writers who have known me intimately. For instance, Sir West Ridgeway, Sir Lepel Griffin, and others who are well-informed officials, have made statements in this connection: they have said, and justly said, that though the Amir rules with an iron hand, it is justified, because he has to rule an iron people. Sir Alfred Lyall, in his well-known verses, gives a picture of the difficult position in which I am placed, in the following words:-

"But all His ways are warnings; and I, God's slave, must lead, How I bargain for help with the Kafir, or lean on a venomous reed;

For never did chief more sorely need Heaven for his aid and stay

Than the man who would reign in this country, and tame Afgháns for a day. 
I look from a fort half-ruined on Kábul spreading below,

On the near hills crowned with cannon, and the far hills piled with snow;

Fair are the vales well-watered, and the vines on the uplands swell,

You might think you were reigning in Heaven-I know I/am ruling in Hell."

What would my critics say if I were to change my strong policy for a weak one? Would not the result be the same as in the case of the Khyber Pass, which the English have not been able to render safe for travellers without a strong body-guard, even after sixty years' rule. Travellers and caravans are still in fear of being killed. But throughout the whole of my kingdom there is no need for guards to travel with the caravans: men and women-even English women - go about day and night without the slightest danger and without body-guards.

When I collect the revenues of my Government I am accused of being greedy, but were I to leave this income to officials and other robbers to put in their own pockets, would my friends, the critics, give me something with which to pay my army and meet the Government expenses?

I cannot help being suspicious when I call to mind past historical events in Afghanistan; for instance, kings have been murdered, unjustly dethroned and treacherously taken prisoners by their internal and external friends, as I may call them. An Epilogue by Sadi runs as follows:

"One day, as I was in the bath, a friend of mine put into my band a piece of scented clay. I took it, and said to it, 'Art thou musk or ambergris, for I am charmed with thy perfume ?' It answered: 'I was a despicable piece of clay, but I was some time in the VOL. II. 
company of the rose; the sweet qualities of my companion were communicated to me, otherwise I should be only a bit of clay as I appear to be !'”

The above quotation from Sadi shows that I have been scented in the wrong way by the effect of the behaviour of my neighbours, as well as those in the country who love to be peaceful! It is natural, that a person should be suspicious when he finds himself surrounded by selfish people who are longing to snatch the first opportunity to take a slice of Afghanistan, just like robbers keenly watching the housekeeper. The moment that his eyes are closed they break into his house; if by chance he awakes, and asks: "What are you doing?" the answer is : "Oh, I am your friend, I am only joking!" If the housekeeper's eyes are turned away, the "friend" takes away his property-in a joke! It is not a happy life to be always suspicious; to be always in fear of being cheated, or killed; but it is a condition of things that is inseparable from such a position as I hold. I often say to my personal friends among the courtiers: "What an unhappy life we all lead! All the time you are in my presence I keep on watching to see which of you, owing to your stupidity, may attack me. And, on the other hand, your anxiety is so great, that you leave your wives and children in suspense, anxiously wondering which of you will return to them safe and sound, and which of you may possibly be hanged for your own offences, or for intriguing with your colleagues and so-called friends."

"It is very sweet," says Sadi, "to sleep under the cooling shade of the trees in the jungle after 
a hot day's march; but this remaining behind the main body of the caravan in a jungle haunted by lurking robbers brings danger to life." I will not waste time in further discussing this unpleasant subject; I will only add before proceeding that, though every Government has its good and bad points and weaknesses, and there is room for criticism, the greatest mistake that any one can make is never to make a mistake ; yet still it is quite certain that every nation will be better ruled by a Government composed of members from among the people. Nations under foreign rule are liable to misunderstandings, because when ruler and ruled belong to two different nationalities their ideas and views of things are also different. I must say, therefore, that I understand my people better than could any ruler from another country.

Foreign Representatives at the Court of Kabul, and Kabul Representatives at Foreign Courts

It is of the highest importance that Afghanistan as an independent kingdom, and one which has a great future before her, should have ambassadors and ministers at all the foreign courts; and that foreign representatives should be received at the Court of Kabul in return. But like many other things that must wait their time until Afghanistan is sufficiently advanced to adopt them, this is also a matter which must be patiently waited for. I advise my sons and successors and my nation to keep on trying to gain this point until they succeed, and thus fulfil the desire of my heart. 
I will mention a few of the advantages as well as disadvantages of such a measure. In one sense Afghanistan is at present in many respects the most independent Muslim Power in the world. Unlike some other Muslim Powers, she is free from the troublesome domination of the Concert of Europe; she is not hampered by any capitulations with foreign Powers; she has no war indemnities or national debt to pay which might necessitate further concessions before allowing her to buy war materials. England is bound by her good faith to fight for the maintenance of the independence of Afghanistan against all aggressors; but for all that England herself is not allowed to interfere in the home policy of my country. England is also bound to send annually a Muslim Envoy to my Court, this Muslim Envoy must be an Indian by birth, and the appointment is subject to my approval. This authority has not been given by England to any other Muslim Court in the world, and no Power in the world has any treaty right to interfere in the internal or external affairs of Afghanistan, with this one exception, that Afghanistan must keep Great Britain informed about her communications with foreign Powers.

There is no reason why, when every other Muslim Power has its representatives at foreign courts, Afghanistan alone should be excepted.

My people must not jump at conclusions without first considering deliberately and carefully the words of my advice: for instance, I would, under no circumstances, allow foreign representatives to be at my Court at present - the time is not yet ripe for 
such a step. In the first place, to invite foreign representatives to Kabul before we are strong enough to defend ourselves against foreign aggression, would be a great mistake. This is a question which must go side by side with opening up railways and instituting telegraphs, after adequate military preparations have been made. The second danger in admitting foreign representatives at present is that my people are not properly educated to understand what is for their own good and vice versa; they are not sufficiently patriotic to understand the value of having their own ruler. The foreign representatives, while on the one hand they persuade my subjects to spread false reports, and to lay complaints against my Government before foreign courts, will, on the other hand, step in to make themselves judges and settle disputes between me and my subjects - disputes caused by themselves in their own interests to divide up my country. The third danger in having foreign representatives at the Court of Afghanistan is that my Government would incur the danger of foreign intrigues in the country, for the purpose of causing disruption among the tribes, and so dividing up the country. And certainly there would be the danger of every one of the Great Powers claiming concessions and control of various matters, if we were thus to give them a chance for every sort of interference. It would be a great drawback to the progress of the country if such things happened before the people are properly prepared for innovations.

But, in the future, when Afghanistan shall have 
arrived at a sufficiently high state of advance and progress, and when she can place an adequate force in the field against her enemies; when, too, her statesmen are educated up to the requirements of their high office, and have gained experience in diplomacy, so that they are able to cope with the intrigues of the foreign ambassadors, then will be the time for admitting foreign representation. The advantages of this course of action are numerous: at the same time, I may mention that, if the Powers were represented at the Court of Afghanistan, such representatives would not allow any one Power to make unjust encroachments upon Afghan territory, or to fight against her without good and sufficient cause being given to justify such a warlike policy.

On the other hand, the representatives of Afghanistan in foreign countries would profit immensely by their experiences at other Courts; this alone would prove of great benefit to the nation generally, and would bring the various communities of other countries into contact with my people. Such a measure if adopted would also open up trade and commerce; travellers would be attracted, capitalists also, to take an interest in the scenery and resources of my country. The larger the number of rich inhabitants that there are in a country the less danger is there of rebellions and tumults, because it is to the interest of a rich community to maintain peace, which means the protection and safety of their possessions and interests. The last but not the least advantage of mutual representation by ambassadors when the proper time comes, would be to add to the 
dignity, fame, and reputation of my Government: Eastern monarchs especially value their prestige and dignity in the eyes of other sovereigns, more than they value anything else.

The world was not made in a day, and God by taking a week in the creation of the world set an example to us that we must have patience, working hard but firmly. The first step in the right direction has been to make arrangements with the British Government to allow their Muslim Indian Envoy to come to my Court, and in return to have my Envoy with the Indian Government, but there are now reasons why it is of the highest importance that as soon as possible we should have our ambassador at the Court of St James. I have made several attempts to succeed in this matter, the most important of which occurred in 1895, when I sent my son, Nasrullah Khan, to England with this special object in view. I was more than hurt by the failure of his mission. Before proceeding any further with this subject, however, I must advise my sons and successors not to take any serious offence on account of this refusal, for we must remember the story of that lover who used to get a sweet melon from the hands of his beloved every day. She used to take great pains to cut it into tiny little slices, and place it upon a costly porcelain plate before him when he visited her. One day it happened that she got hold of a very bitter melon by mistake, and as she had not tasted it herself, she put it before him as usual. The man went on eating it without saying a word about its bitterness. When the last 
piece only of the melon was left upon the plate, one of his friends came in and took it up to eat, but finding it so bitter, asked his friend why he had not told his beloved of the bitterness of the melon. He answered that it would have been most ungrateful after having eaten a sweet melon every day for months to grumble about a bitter melon which he had only to eat once. This of course endeared him more in the eyes of his ideal! Among the many proofs of favour which Queen Victoria, her family, and Government have shown me and members of my family and Government, we must bear one bitter refusal.

Not only is it dangerous for Afghanistan to have no representative at the Court of London; it is equally dangerous for England herself, if not more dangerous, than for Afghanistan. It is a very great pity that England should attach so little importance to the safety of the Indian frontier; or, in other words, to India; which has made England into an Empire. It is well known to the world that it is only in this Queen's reign that the title of Empress was assumed, and that her Government became an Imperial Government. It was the possession of India which first gave to England a dignity greater than that of Holland or other small countries. The loss of India to Great Britain means the loss of what made her into an Empire: she should therefore take every precaution to ensure the safety of India against its invasion by any foreign Power or Powers. Still, there is so little known about India, and so little interest taken in Indian affairs in England, that one feels 
inclined to think that there is some truth in the version of those people who say: " $\mathrm{Oh}$, England does not think that India is worth the anxieties which it gives her at present, and therefore, if the worst comes to the worst, she will leave it." I do hope and pray that this is not the desire of the hearts of the British public, for, though if the British leave India they have other places to live in, yet other states and Powers which have severed their relations with other Powers, putting their confidence in the support of Great Britain, will have no other homes to go to in the event of their country being annexed by their neighbours. But if, unfortunately, England intends to leave India without fighting for its safety and protection to the bitter end, the sooner that she informs her friends the better it will be for them, because, in such a case, her friends can take any course they choose for their own safety. I do not believe that Russia has any enmity against Afghanistan, regarding it only as a rather serious obstacle in her way to India, and if Russia ever did attack Afghanistan it would be only upon this account. This point, I will, however, discuss in another place.

The articles which appear from time to time in many newpapers and magazines concerning Afghanistan, and the speeches that are made by some members of Parliament, show how little is known about my country and its relations with India, and the value of its friendship. For instance, Russia is doing everything in her power to come close to England in the East, on land, and to have all her frontier line joined with the frontier line of the Indian Empire. Some- 
times I am amused and sometimes I am sad, to think of the ignorance displayed by Members of Parliament in their speeches. They say: "We must not let Afghanistan stand in our way; we must join our railway lines with those of Russia; we must clear out this uncivilized spot, taking ourselves up to Kandahar on one side of the Hindu Kush and leaving to Russia the other side of the Hindu Kush." These true friends of Russia and pioneers of peace, these wise enemies of Great Britain, do not understand that they are fighting for the interests and the desires of Russia at the expense of England.

It is a well-known fact that when two nations do not know each other well, and do not associate or come into touch with each other, frequent misunderstandings arise from this very eause, such misunderstandings being fatal to all friendly intercourse and friendly relations. Nothing can be done by diplomacy where suspicion exists, because every word that is spoken is looked upon with suspicion and distrust, and is in consequence misconstrued. How is it possible for the Afghans and the British to understand each other when politicians, or rather, the Indian Government, are always trying to keep them aloof by not appointing an Afghan Embassy?

It will be, as I have said, a long time before Afghanistan is in a position to allow the representatives of any other Power but England to take up residence at Kabul, as also for Afghan representatives to be appointed to any other Court but that of London. So far as England is concerned, however, such a measure would bring her into closer touch with Afghanistan 
than at present; it would cement firmly the friendship which already exists; it would clear up many misunderstandings and suspicions; it would introduce a true knowledge of the power, the education, and the modern inventions of Great Britain to the Afghans in their own country. It would open up the way and encourage Afghan youths to go to England and Europe for their education; it would give true and useful information and knowledge of Eastern affairs and policy to the Government in England, and would contradict many false statements that cause distrust of our nation among foreigners; it would put Afghanistan into the position, in the eyes of the world, and especially in the eyes of other Muslim sovereigns, of a fully recognised independent kingdom, as it is acknowledged to be by Great Britain herself-in theory! There is no reason why it should not be so recognised in practice. As far as my experience goes, whenever I have managed with the greatest difficulty to get my letters laid before the proper authorities in England, the answer has always been to refer me, in polite but firm language, to the Indian Government, saying that I must lay my ease before them. It is all very well to ask a person to put his case before a judge against whom he is making a complaint!

Though English writers and politicians are almost unanimous in their agreement that war with Afghanistan is a mistake, after such war has been brought about by their Viceroy, what is the use of trying to save the spilt milk when it is too late? Sadi says: "A fool does the same thing that a wise man 
does; the only difference being, simply, that the fool does it after suffering for his mistake, and the wise person does it before he suffers." Instead of first taking poison, and then going to a doctor for an antidote, it is better not to take poison at all.

The changes that the English policy has undergone concerning Afghanistan show very clearly that the English have never grasped the full meaning of their relations towards Afghanistan. I will give a few of the more important changes without going into details. The first policy was at the time of my grandfather, Dost Mahomed Khan, when they interfered in the domestic broils of the ruling family of Afghanistan, putting one man on the throne, and dethroning the other. The English here tried to dethrone and imprison my grandfather, Dost Mahomed Khan, who had given them no offence- a step for which they had no justification. It was not an honest policy to place Shah Shujah on the throne against the wishes of the Afghan people by the force of English bayonets. This policy resulted in the terrible disaster to the English forces at Kabul. This taught them the lesson never to interfere in the domestic quarrels of the Afghan claimants to the throne of Kabul.

Then came the second stage- "a passive policy," or the policy of leaving Afghanistan alone, which policy, although called by the English strong, I call weak and timid: the putting of Amir Shere Ali Khan under the influence and into the arms of Russia, which resulted in the Second Afghan War. It is a curious thing that England did not ask Russia 
for an explanation of her conduct in giving protection to Shere Ali, and for interfering with Afghanistan, in the face of her standing treaties with Great Britain, which were against any such measures, but they punished Shere Ali for this, though Lord Lytton himself had ordered him to write letters to General Kaufmann. I do not say that Amir Shere Ali was not guilty of breaking his faith with England, but I certainly say that it was caused by the so-called passive and inactive policy of the Indian Government: in other words, leaving Afghanistan to its own fate.

Then came the third policy - that of Lord Lytton, who tried to cut Afghanistan up into small pieces, dividing it up into parts, by leaving Kandahar and certain other provinces under the possession of . Great Britain, the other parts being divided between other rulers. This also was disapproved, but the so-called "Forward Policy" is an offspring of Lord Lytton's policy.

Then followed the fourth policy, namely, that of keeping Afghanistan as an independent kingdom and a strong barrier for the safety of the Indian Empire, owing to her position between Russia and India. I am happy to say that this is the policy which is at present wisely adopted by the Government in England as well as by the Indian Government. It is, however, somewhat disappointing to find that it is not carried out to the extent it ought to be.

The arguments brought against my having a representative in London are as many as there are mouths of Anglo-Indians, and perhaps even a few more, including the supporters of the "Forward 
Policy" in England; I will deal only with the few. First, I am told that I cannot have a representative in London without having a representative of Russia at Kabul. I see no reason for this, when there is already my representative with the Government of India, and the representative of the Government of India at Kabul, and there is no representative of Russia at Kabul at the same time. And, besides, my treaty with Great Britain stipulates that I must have no relations with any foreign Power, except England herself, therefore neither Russia nor any other Power has any right to force me to have their representative on the mere argument of my having one in London. I have entered into no treaties with any foreign Power of any kind, and I have given no promises to the effect that I cannot have my representative in London without their interference. If $\mathrm{I}$, of my own free will, desire to have relations only with Great Britain, what has Russia or any other Power to do with it? In short, I can do anything that I like in this respect without any Power having a right or justification for interfering with me.

I am also told that I cannot have my representative in London without having a Queen's representative at Kabul, and that this Queen's representative must be an Englishman! This definition of "Queen's representative" I cannot understand. There is no reason why this excuse should be made, as there is already a Muslim representative at my Court, who is officially addressed "British Agent at Kabul," and not "Viceroy's Agent at Kabul," which proves that this is merely an excuse. I daresay that the time will 
come when an Englishman will be admitted as the British Agent at my Court, but at present the difficulty is this. Anglo-Indians have got into the habit of looking on the Indian Princes and rulers merely as tools in their hands and in the hands of the British Agents in the Indian states, named Residents. In my opinion, these Residents are the real rulers, the rulers themselves being entirely at the mercy of the arbitrary powers of these Residents, who give themselves the airs of sovereigns, and behave in a way that the proud Afghans will not stand. It would be far safer if the British Agent were a Mahomedan, and the excuse that the Queen's representative should be an Englishman can be easily put aside by the argument that all the British Agents are not Englishmen, nor are the British officials and politicians always Englishmen. This causes the other loyal subjects of the Queen, who are not Englishmen, to imagine that they are looked upon with mistrust, while they are quite as loyal as Englishmen, if not more so. I have no objection, personally, to an English Resident, if the English Government will be responsible for his safety and good behaviour. The English nation can understand the position better if I say that there are various commercial agents and the like, who have been in my service in different capacities, and who, though they never had any share whatever in the affairs of my Government, and in fact knew nothing about my internal or external policy, still call themselves in England my advisers and my right-hands and personal friends. On some occasions indeed, it has been brought to my notice that Englishmen have been 
made to believe by these people that I was under their control. If, therefore, an ordinary shopkeeper or workman boasts in such a manner, what could not be expected from a Queen's political agent, if he was an Englishman?

Another argument is: that I get 18 lakhs of rupees annually from the Indian Government, and therefore I must not have my representative in London. Now, I did not accept this subsidy on any such conditions; it is given to me for various reasons, but not one of them mentions anything about this matter, either in connection with London or India. The payment of this subsidy does not minimise my dignity: on the contrary, it raises the value of my friendship, and England does not give her money in vain. History is full of instances where monarchs receiving subsidies from other sovereigns were also permanently represented at their Courts. Great Britain herself paid subsidies to more than one Continental prince in good old times, and her sovereign received the agents of the subsidised princes without hesitation.

Another argument is, that by admitting my representative, the British Government would be treating me as an independent monarch: but $I$ am an independent monarch already; I am officially announced on more than a dozen occasions as an independent king: I am addressed as the " King of the God-granted kingdom of Afghanistan;" my own nation gave me the title of "King and Light of their Nation and Religion," to which the Viceroy responded most cordially.

Some critics say that if there were an Afghan Minister in London, directly communicating with the 
Government, complications would arise between the Foreign Office at Simla and my Government. I myself do not think so. My agent, who is with the Viceroy, need never be withdrawn, but in the case of serious friction arising between my Government and the Viceroy, both he and my representative in London could put our case before the Secretary of State in London, which would enable the Cabinet Ministers to hear both sides of the question before giving their judgment, thus controlling that mistaken policy by which only one side is heard. As things are at present, Afghanistan has no chance whatever of explaining the true state of affairs.

I have been trying hard to persuade my people to give up their old hostile feelings towards the British nation, and to become true friends and allies with them. Under these conditions, if one of their countrymen should be appointed as Minister residing in the city of London, the communication and intercourse would inspire friendly feelings in the hearts of both nations, and the British nation would know a little more about the Afghans than they do at present, or are likely to do, under present conditions.

I do not agree with some English statesmen and generals, who say in their written articles that the less they see of the Afghans the better they will like them! On the contrary, the more that the English and the Afghans see of each other in a friendly manner, the more likely it will be for these plants of friendship to flourish, the seeds of which have been sown by me. But of course if the English writers mean by this that the less they see of the Afghans, with the intention of invading their vol. II. 
country, or with the design of interfering in their internal policy; in that ease, it is quite true that the less they see of us the better. But I do not think they will bite anybody without being troubled. However, my advice to my sons and successors is to draw in the ties of friendship with the British nation as soon and as closely as they will allow them to do. In the event of the British not receiving the overtures of my sons and successors favourably, the latter must not complain, otherwise they will lose even what they possess already, as exemplified in the story of a person who was dreaming that God offered him some pence. He said: "No, I want precious stones;" then God offered him silver coins; the man still insisted on precious stones. He was then offered a few gold coins, and he demanded more. All at once he awoke and found he had nothing at all, so closing his eyes again, he stretched out his hands, and said: "Give me whatever you like; I will take it and be thankful." But it was too late-he got nothing! 


\title{
CHAPTER VIII
}

\author{
ENGLAND, RUSSIA, AND AFGHANISTAN
}

IN my opinion, this last portion of my book is the most complicated and difficult one to deal with; but everything that I shall say in this section is the outcome of an experience achieved by me during my whole life, which has been full of difficulties, anxieties, adventures, travellings and various kinds of responsibilities. From my childhood up to 1880 , nearly forty years of my life were passed in Russia, or on the borders of Russia, or else in travelling near the Russo-Chinese and Perso-Russian frontiers. From 1880 up to the present day I have spent all my time in studying the policies and characters of my two strong neighbours-namely, England and Russia. It would be unwise as well as impolitic to reveal the sources from which I have derived my information, and which are still open to me. By means of these sources I am able to deal with this subject from the point of view of experience. I will therefore merely state facts, without giving reasons or full details of such a nature as would reveal the secrets of my Government. I do not take into consideration the opinions or writings of the statesmen, 
travellers and literary people in various countries, and it is not my object to criticise their opinions or to invite criticism from them. I speak only what I think wise for my sons and successors and my nation to know and follow. In giving my opinion I shall try to be very impartial and frank, and will endeavour not to appear either as a Russophobe or a Russophile-neither pro-English nor anti-English.

\section{The Policy of Russia and Great Britain towards Islamic Powers in Asia.}

The Russian policy in Asia is, that in any way, rightly or wrongly, friendly or unfriendly, with peace or war, the Islamic kingdoms should be washed away from the face of the Asiatic continent. They would be glad if Turkey, Persia, and Afghanistan ceased to exist as kingdoms, but were maintained merely to be used as tools in the service of Russia herself, in which case it would be a matter of indifference whether they existed or not, and their duration would simply depend upon the length of time that Russia required them to serve her purpose. It is Russia's desire to absorb and swallow up Persia, Turkey, and Afghanistan, but in the event of this plan failing, she would then try to cut off the Islamic Governments from the friendship of England, and draw them towards herself, so that they might take up arms against England. In this case also the Islamic Governments would end by being absorbed into Russia. Russia thinks that having failed in either of the above policies, the third 
policy to adopt would be to cause misunderstandings between England and the Islamic kingdoms, in such a manner that Russia might find her opportunity to arrange with England in the division of these Islamic kingdoms, and by the help of Great Britain to bring about a general disarmament of the Central Asiatic Muslims. The last, but not the least, matter of important policy that Russia has at heart is to keep the various Muslim governments and communities of Asia in a state of disunion among themselves, as well as to cut them off from England. Russia knows well that if at any time she were engaged in a war with any of these Muslim kingdoms, or with Great Britain, there would be a general rising throughout all her Muslim subjects; this would be a very serious matter for her, because, in the event of such a general rising, the whole vast empire would fall into pieces and be divided up into petty states-the usual end to all empires ruled by force and despotism. To prove the truth of my statement about Russia's desire to ruin or divide the Muslim kingdoms, or at least to weaken them, the recorded events in past history are sufficient for reference to scholars and students of politics and Asiatic affairs.

During the years of my residence in Russia I had the opportunity upon many occasions of discussing politics with General Kaufmann, the then GovernorGeneral of Russian Turkestan, and other Russian politicians. I then became fully convinced and informed about the above policy towards the destruction of Mahomedan Powers. How very little Russia expected at that time that I should be king of 
Afghanistan and the strongest opposer of this policy at some future date! One instance may be quoted to give a clear idea of the treachery of Russia, as well as the policy stated above. In 1875 , when I was in the position of seeing General Kaufmann and of knowing his private and public plans, he wrote to his Government through the then Russian Minister in London, Count Schouvaloff, as follows :-

"Russia and England had in Asia one common interest and one common foe. Their common interest was civilization and the separating of the Christian religion, the faith of both countries; and their common foe was Islamism, the only danger to the British rule in India; the other dangers being merely imaginary. Islamism would prove a very real and dangerous enemy of England in India, and the Mahomedan subjects of India would make use of the first favourable opportunity to rouse up a general rising against England in India; it is a matter, therefore, of the very highest importance that England should be closely allied and united with Russia, and that Afghanistan, as well as other Central Asiatic Mahomedan States, ought to be divided between Russia and England, so that the frontiers of the Indian Empire and that of Russia should be closely in touch with each other. This would save England from every anxiety, because she would have her true friend the Christian Empire, Russia, near at hand to help her at times of risings in India, or in any other difficulties with which she might be embarrassed. England ought therefore to throw herself entirely on the friendly assurances and promises of Russian support," etc.

During the whole time that the Russian Ambassador in London was trying to make Great Britain believe in the peace-loving friendship of Russia towards England, and her hatred to Afghanistan, Russia was, in an underhand 
way, communicating with Shere Ali Khan, telling him the very opposite, by which smooth words they persuaded him to turn against England and enter into an alliance with themselves. In this way Russia succeeded in sowing the seeds of discord between England and Afghanistan, which resulted in a war in which great loss of men and money was suffered by England and Afghanistan. This story of the Russians reminds me of the story of an agent who used to take his commission from the housebreakers as well as from the householders, by telling the burglar; "You ean go and steal as much as you like, as there is nobody awake at this moment," the burglar giving him his commission for the friendly advice. Immediately afterwards, the agent would go to the householder, awaking him, and warning him of the intended visit of the burglar, thus earning a commission from him likewise.

Amir Shere Ali Khan, who was foolish enough to believe in Russian promises and support, was left to his own ruin by the Russian Agent, who departed from Kabul the moment he had succeeded in making war between Shere Ali Khan and England. The English Government, on the other hand, could not make Russia pay for breaking her promise of non-interference in Afghan affairs. Instead of opposing the Russian policy of weakening Afghanistan, the English supported that policy by cutting off Kandahar, Kuram, Khyber, and other provinces, from the kingdom of Afghanistan. This of course brought the Indian frontier nearer to the Russian possessions in Asia, and weakened Afghanistan, which was the object that Russia had had in view all along, and was the desire of her heart. This 
was the gist of General Kaufmann's policy, as quoted above.

In short, the policy of the Russian Government towards the Amir of Bokhara, the other Mirs of Central Asia, as well as towards Turkey, Persia, and Afghanistan, has always been directed towards the prevention of their becoming strong Powers to oppose their everlasting aggression. Gradually, slowly, but firmly and constantly, Russia takes advantage of the difficulties and weakness of the Asiatic Powers, benefiting herself by the losses of others. She has taken some of the Islamic States entirely, others partially, into her possession, and she cannot bear the sight of any military preparations set on foot by any of the Islamic sovereigns. The one point which is quite correct in General Kaufmann's statement, above quoted, is this, that Russia has a dangerous foe in Islamism, and not without reason.

The English policy, on the other hand, towards Islam in general and all the Islamic Powers in Asia, is friendly, and her whole desire is that they should continue and remain strong and independent. But this policy is subject to occasional temporary fits and changes. The English policy is not like that of Russia-constant, firm, and permanent. The ideas and notions of any statesman or leader who is in power in England become, for the time being, the policy of the empire, and his instructions are followed by his Ministry. But when a sudden change occurs and clears him out of office, the policy of another person, whose views are the very opposite of those of the former leader, become, in their turn, the policy 
of the Empire. It cannot therefore be said that such and such a policy of Great Britain is permanent, but so much is certain, that the general policy of Great Britain has been for a long time past to the following effect: namely, that the Islamic Governments, which are a barrier and strong wall between India and Asiatic Russia, should exist and have their independence strongly maintained, to continue as a strong barrier wall in the way of Russian advance towards India. On the other hand, the Russian policy is the very opposite, not only because she wishes to join her borders with those of India, but because she has the fear ever before her of general Mahomedan risings against her at times when she may be engaged in war with Turkey, Persia, Afghanistan, or India.

There is no doubt that Mahomedans all over the world prefer the friendship of the British Empire to that of Russia; they consider that their friendship and peace rest in being on friendly terms with Great Britain. It is for this reason, therefore, that notwithstanding the fact that they may have more causes of complaint against England than against Russia, they will never be desirous of joining hands with Russia against England, and, if they ever do so, it will be because they have been forced into it.

Considering the above arguments, one matter is of very great importanee as regards the interests of Great Britain and the Indian Empire, as well as for the interests of Turkey, Persia, and Afghanistan. It is merely a suggestion which, if accepted by the statesmen of these Governments, would prove of very great 
advantage to all of them. It is that Turkey, Persia, and Afghanistan, which are three brother Muslim kingdoms and states of one faith, ought to be closely united with each other, and, if possible, to have their eapitals connected by railways and telegraphs. This would make a strong wall in the face of constant Russian aggression towards India, and also protect the Islamic Governments themselves. As the foundation of such a triple alliance is for the benefit of Great Britain, and depends largely upon the desire and help of Great Britain, the sooner that the English Government takes steps to bring this about the better. Turkey and Persia are already trying to cement friendly feelings between themselves, but Afghanistan, having a treaty with Great Britain not to carry on any political communications with other foreign Powers without the knowledge and advice of Great Britain, cannot communicate with Persia or Turkey, though Afghanistan looks upon the interests of Persia and Turkey as her own. Of course the policy of the Sultan of Turkey, or of the Shah of Persia, or my own policy, is to keep and maintain our own independence and integrity, neither allowing Russia nor England to take any part of our dominions, and to stick to such one of our neighbours as will respect our integrity and independence, and to fight against those who try to weaken our power. And we, knowing that England does not want any of our dominions, but rather to keep as far away from Russia as possible, are naturally bound to keep on friendly terms with Great Britain as long as she holds to this policy of non-interference and supporting our dominions. 
I must give one example to show that it is to the interests of Great Britain that the Muslim sovereigns of Asia should be closely united to each other. In 1877, when Amir Shere Ali Khan was proclaiming Jihad against the English, and was concentrating his troops on the Indian frontier, one of the Mahomedans who visited Amir Shere Ali's Court as a representative of the Sultan of Turkey, tried to persuade the Amir not to proclaim Jihad against the English. The Amir had also stopped the mobilisation of his armies on the borders of India; the Indian Government noticed this sudden change in the mind of the Amir in favour of the English, which had been brought about by the influence that the Sultan's representative had brought to bear upon the Amir. Unfortunately, however, the Amir having had no previous communications with the Sultan of Turkey, was rendered suspicious about this representative, as the friends of Russia who were at the Court of the Amir told him that he was nothing but a puppet in the hands of his advisers. They further said that this so-called representative of the Sultan of Turkey was a spy sent by the English to deceive him. The Amir was foolish enough to believe these stories without endeavouring to find out from the Government of Turkey if they were true. The mission of this representative was, therefore, a failure. Had there been a permanent means of communication between these two Islamic Governments, it would have been of very great advantage to the English as well as to Afghanistan.

In short, so long as England and Afghanistan are 
friendly, and realise that their advantages and disadvantages are mutual, Russia will never dream of invading Afghanistan or India with any chance of success. Should Russia be so foolish as to attack Afghanistan or any other Islamic Power (though I believe she knows better than to do so), which should be honestly and truly supported by Great Britain, Russia would find herself in such difficulties from facing the Mahomedan Power in front and a general Mahomedan rising within her dominions behind, with perhaps an attack upon St Petersburg by the British Navy, or upon some other part of her European Empire, that this immense Empire, which is ruled not by love but by fear, would fall into pieces and become disintegrated.

It is very saddening to see that the British Empire, instead of supporting the Mahomedan sovereigns and making them strong enough to hold their own against Russia; or instead of stopping Russian aggression and interference in Asiatic States, contrary to her standing treaties, vows and promises, so acts that whenever Russia takes one portion of any of the Oriental countries to encroach near to the Indian borders, the English take another piece from the corner to shorten the distance from Russia. In this way, the Islamic Governments and States are being divided up day by day, and the frontiers of India and Russia which used to be thousands of miles away from each other, are now nearly touching.

In any case of the breaking out of hostilities between Great Britain and Russia, all the Mahomedan sovereigns and communities would support England. 
Firstly, on account of the free exercise of their religion which they enjoy under the rule of the Queen, and more especially because they know that they are safe from Russian persecution and tyranny only so long as there is another great Empire like England to oppose Russia in the East. They know that the downfall of England in the East would end in the Muslim countries being absorbed by Russia. Those people who believe that the Persians are more under the influence of Russia than that of England, are wrong; they must know that it is the constant fear of Russian force which makes Persia obliged to keep quiet and to suffer under Russian influence. Should Persia ever see Russia in serious trouble with England, Persia would be the first Power to release herself from the bear's claws.

Having reviewed the relations of England and Russia towards the Islamic States and religious communities of Asia, I will proceed to mention a few points which especially concern Afghanistan, in addition to the points already given.

Russian Invasion of India and her Policy towards Afghanistan

In the last section I mentioned the Russian policy towards the Mahomedan States of Central Asia, in which, of course, Afghanistan is included. But in addition to what I have already said, I will mention a few more points here which concern Afghanistan particularly.

Russian invasion of India would be not only 
difficult-but impossible, so far as one can judge from present conditions. It does not follow, however, that Russia has no intention of invading India; there is not the slightest doubt that Russia is determined and certain in her heart to attack India whenever she finds an opportunity to do so. The ideas of English statesmen differ vastly in this respect, and there are not a few who hold the opinion that Russia has no intention of fighting England in India. People who say that Russia has no desire to attack India or the British Empire in the East, I classify under four headings: firstly, those who are not politicians. These people are so simple that having before the eyes of their mind dozens of treaties and vows broken by Russia, still go on putting their confidence in Russian declarations of peace and further false promises. They are unable to understand that the Russian policy is to break their treaties and oaths at any moment that suits their purpose. In taking a new country they enter into new promises, and are again believed by some English officials, who have very bad memories for the former promises of Russia.

Secondly, The second group is that which is directly or indirectly inspired by Russian policy to plead her cause.

Thirdly, This group consists of those who are proud of the great Empire of Great Britain, and, owing to their ideas of their own greatness, imagine that it is impossible for Russia ever to think of opposing their mighty power.

Fourthly, The group of people who call themselves lovers of peace. They see Russia swallowing up 
Central Asia, province after province, and gradually encroaching on the borders of India: they see that on various occasions in the past Russian plans and plots for the invasion of India have been fully proved and found out. But knowing this, they still believe that if England maintained the policy of not opposing Russian aggression, and pretending that Russia has no intention of invading India-in that case Russia would never attack India. Firdusi, the author of "Shah Namah" ("History of the Kings"), says that if you will show to your enemy that you are not prepared to go to war and shrink from it, you will invite him to attack you. The example of the last-mentioned group reminds me of the pigeon who, seeing a cat coming towards him, closed his eyes, thinking that if he did not see the cat, the cat would not see him; but the eat did see him, and caught him and ate him up.

In addition to what I have said elsewhere to support my statement in this respect, I will add for the information of my readers that throughout my twelve years' residence in Russia I discovered that there is not the slightest doubt that Russia is always plotting towards one end, the invasion of India.

To give the full details of all the causes that would induce Russia to attack India would require a volume all to itself. It is sufficient to say here that the Russians are by nature an aggressive, grabbing and pushing race, fully aware that all the Asiatic States are too weak to resist their aggression singlehanded, except Great Britain in India, and Great Britain alone; it is therefore natural that Russia should 
regard Great Britain as her only formidable enemy and rival in Asia. Every one knows that were not Great Britain in the way, Russia would take little heed of the Powers of Persia, Afghanistan, China, and Turkey, nor would she respect their independence very long. No other European Power but Great Britain has any possessions in the East worth speaking of, and they would be quite satisfied to stand by and let Russia take her own course if she allowed them a small share of her booty. England has a larger population in her Eastern Empire than Russia, and it is to the interest of England to oppose Russian aggression upon the weak Powers of Asia, and to keep her away from the borders of India. That Russia hates the sight of a great Power like Great Britain in the East is quite natural. She cannot very easily forget what she suffered at the hands of Great Britain during the time of the Crimean war, and the opposition she has received on various occasions.

The Russian people look upon India as a great treasure-house for gold and looting, and I have often seen Russian soldiers jumping for joy at the idea that they might one day have a hand in plundering this rich country, and they longed for the day when fighting should begin between England and Russia upon the borders of India. The Russians are so hopelessly ignorant that they believe that Indians do not love the English, and are devoted to the Russian bear, and that they worship the ground upon which it treads. Even some of the great Russian statesmen believe that the moment Russia 
glances down from the peaks of the Himalayas and the Hindu Kush mountains towards India, the Indians would rise like a swarm of wasps to sting and crush the English and support Russia. Indeed their ignorance is so profound that it is a common belief that directly Russia should make her appearance the English would flee away precipitately without striking one blow in self-defence. I am afraid the Russians will suffer for this stupid folly some day.

The Russians believe that they can go on breaking promises and treaties and advancing further and ever moving onward; on the other hand, the English show either indifference to this constant aggression or satisfy themselves by taking a corner for themselves, which is a definite proof of England's weakness and the terror with which she regards Russia. By thus allowing Russia to continue her constant advance without strong protest, the prestige of the latter is greatly increased in the eyes of Oriental monarchs, while that of England is decreased, as well as her influence being lessened. This constant increase in Russian influence makes the Russians believe that the Oriental States are sure to side with Russia, willingly or unwillingly.

The fifth and perhaps the only reasonable belief that Russia holds is that it is very difficult to fight with England upon the sea, but that on land England has not an army large enough to spare from other parts of her vast Empire to protect thousands of miles of frontier, as would be the case when Russian boundaries should touch those of England, from China up to Turkey; which day, according to the VOL. II. 
Russian belief and their present activity in making railways and roads, is not very far off.

Having explained that Russia is determined to attack India sooner or later, when she can find a favourable opportunity, several questions arise for our consideration.

I am not a prophet, and the teachings of our religion are, that "God alone knows the hidden mysteries of the future, and to Him alone are the gates of the secrets of the future revealed." (Koran). No one ean say for certain what is to happen tomorrow, but taking matters as they stand at the present time, I will give my views and opinion.

I do not believe in the word "impossible" when applied to any matter; in fact there is no such thing as impossibility, because if it is the Divine Will that a thing should happen, it is certain to do so, though it may appear impossible to us-nothing is impossible for God. If $\mathrm{He}$ does not wish certain events to occur, no earthly power can bring it about against the Divine Will. It is therefore not beyond the bounds of possibility that Russia may attack India. But she can never carry out this plan without the support and combination of some other Power, and as there is no likelihood of any other Power uniting with Russia to invade India, without, at the same time, some Power joining England also, these designs of Russia are nothing but delusive dreams which will never be fulfilled. It is possible that this Russian dream might be partially fulfilled, as was the dream of a doctor who, having cured a patient, was told to take as many gold coins out 
of the treasury as he could carry on his shoulders. The greedy doctor overloaded himself to such an extent, that the heavy burden broke his shoulders; and, feeling a severe pain in that part of his body, he suddenly awoke and found that there were no gold coins, but that the pain was there. The Russians will take upon themselves as many unnecessary burdens and pains for the purpose of invading India, and plundering its treasure, as did the doctor in his dream, and the result will be failure in an attack on India, but the pains of the undertaking will remain.

But let us now examine the idea of another Power joining Russia in her invasion of India. There is not the slightest doubt that some of the European Powers view the greatness and strength of the British Empire with prejudiced and jealous eyes; this obliquity of vision makes them adopt an unnecessarily hostile attitude towards England. All the same I do not think that these Powers are permeated by any great love for Russia, and it certainly would not be to their interests to side with Russia against England, which country is less aggressive and less tyrannical than Russia. During the last few years the tendency of the French nation towards making friends with Russia has increased, while, at the same time, her hatred to England has also continued to grow. This makes me think that possibly France, in remembering her old differences with England in India and at Waterloo, might join hands with Russia, who has also some old debts to pay to England. It is, however, quite obvious to an attentive observer of the march of diplomatic events, that if France 
supports Russia, Germany, on her part, will help England. It is equally certain that Germany and England together are much stronger than Russia and France, England being the first Naval Power in the world, and Germany having the greatest and most perfect military organization.

I believe that Austria, Italy, and America, though not openly hostile to Russia, and not particularly friendly towards England, and consequently looked upon as neutral Powers, yet have a decided leaning towards England, which would tell in her favour, and against Russia. Putting these considerations before our mind's eye, we cannot see how any of the European Powers or America could enter into any offensive alliance with Russia in the invasion of India without at the same time causing the rival Powers to join England in a defensive alliance; such a combination would result in one of the most terrible Continental wars the world has ever known-a war, indeed, which might extend all over the world. This has been prophesied by some authorities.

Now, leaving the question of combination between European Powers to support either England or Russia, we will consider such a combination of Asiatic Powers. Except Japan, every one of the Asiatic rulers are anxious to keep only their own territories; they have no desire to join Russia and fight against England, nor to join England in a war against Russia. They regard Russia and England as two more or less aggressive, powerful, absorbing Powers: they are, therefore, only anxious to keep out of their way and to maintain their own independence, integrity, and safety as long as they can. 
For these reasons, none of them have a desire to join Russia in any projected invasion of India. More than this, they believe that their safety lies in both Russia and England being strong in Asia, so that they can oppose each other in aggressions upon the countries of weak Asiatic rulers, who regard the rivalries of these two Powers as their safeguard and blessing, and a preventative against their being partitioned off between the two-as every Pharaoh requires a Moses to keep him in check. One of the poets says: "To catch the bear of the desert of Mazindran, the bull-dog of Mazindran is necessary." The Japanese Empire is not in Central Asia ; it is, therefore, not in the way of Russian advance towards India : for this reason, Japan is not bound to join either Power in an invasion of India, as would be the case with Afghanistan. It is most certainly to the interest of the Japanese Empire to see the British naval power strong in the Asiatic seas ; it is their earnest desire that this should be so, and that friendly relations should ever exist between their respective countries, and that they should always fear Russian aggression in an easterly direction. All this proves that there is no likelihood of any of the Asiatic Powers joining hands with Russia in an invasion of India.

But the kingdom of Afghanistan is a growing Power, a Power which will be of the greatest importance, and which must always be reckoned with by Russia and England in their designs upon each other. To either of these two great and mighty neighbours the friendship or enmity of a strong Afghanistan is of far greater importance in Asia than that of any other great Empire in the world, for the reason that Afghanistan has a brave army 
at her disposal, numbering hundreds of thousands of Islamic heroes, who are born warriors, whether trained soldiers or simple peasants, and who would all sacrifice every drop of blood till the last man was killed, in fighting for their God, their Prophet, their religion, their homes, their families, their nation, their Sovereign, their liberty and independence. The ruler of Afghanistan is also of great importance, on account of the political and geographical position of his country.

Should Afghanistan be in existence at the time of a war breaking out between Russia and England, that Power would certainly be victorious which could secure the support of Afghanistan. In fact, I consider that, so long as Afghanistan exists and remains united within itself and with Great Britain, it is impossible for Russia ever to attempt to attack India, or to go to war against England in Asia. Russia is perfectly well aware of this fact, and knowing the impossibility of attacking India so long as Afghanistan maintains her strength and independence, she desires either to draw Afghanistan into a friendly alliance with herself, or to put her out of the way by some trick or other. It is a matter of the most vital importance to watch this game of Russian politicians in trying to put Afghanistan out of the way, and constant and close observation, as well as far-sighted precaution, should be exercised by the rulers of Afghanistan and of the British Empire.

I may mention here that luckily Russia knows the difficulties that attend going to war against Afghanistan better than those whose sources of information are chiefly some almanacs or books, and articles written by authors, who, after flying through a country in a week 
or a few days, ignorant even of the language of the people, write large volumes on the secrets and hidden policies, feelings, and motives of the people of the country. These books and articles are considered great authorities by the public, who should know better than to trust the information contained in them, for they do more harm than good, giving as they do utterly false ideas of the country, its ruler, its institutions, and its people.

It is most ridiculous, and I often laugh heartily at the ignorance of these writers. I will give an instance. During the last forty years many writers have given the number of the population of Afghanistan at 5,000,000; the fighting force at 35,000 men. These numbers neither increase nor decrease, according to their account, having stood at these figures for nearly half a century. I do not blame them for their ignorance, because they have no means of knowing the position of the country, or the changes it has gone through. But I do blame writers for pretending to know what they do not, and for deceiving the public by giving them wrong information. Still I am thankful to know that they do not reduce the population or the army, which they are quite capable of doing.

Afghanistan is not strong enough to stand alone, and is bound, for her own safety, to lean upon one of her two strong neighbours against the aggression of the other. A person who puts his feet on two boats to cross a river, is bound to fall into the water and be drowned; he must, therefore, stand on one or the other, whichever he thinks the safer. But there is no reason why he should fire on the one while he is riding on 
the other, unless necessity arises. How can a small Power like Afghanistan, which is like a goat between these two lions, or a grain of wheat between two strong millstones of the grinding mill, stand in the midway of the stones without being ground to dust? It is of the highest importance that one of her strong neighbours should support and protect her against the aggression of the other. Afghanistan is quite free and independent to choose whichever of her two neighbours she prefers, upon whom to bestow her friendship and support, so that the other should not attack her with impunity. I believe that though the railway lines and roads that Russia has made, and brought up close to my country, are the cause of much anxiety to us, and keep us wide-awake to whatever may happen, yet, in one respect, this close neighbourhood of Russia is to the benefit of Afghanistan, in that, should England, without good reason and without any fault on the part of Afghanistan, try to annex their country, she knows that Russia is elose enough to advance upon her. For this reason, Afghanistan is not in the same position today as she was at the time of Shah Shujah and Amir Shere Ali, when Russia was so far off that it was impossible for her to bring her armies to the borders of Afghanistan through the deserts, where there were no railways and no water.

Having explained that Afghanistan is of necessity obliged to be united with one of her strong neighbours, there is no doubt that at present it is to her advantage and interest to choose England, and to lean upon the friendship and support of England. 
Firstly, because England has no intentions of invading Persia or Turkestan, to compass which they might require a road through Afghanistan; while Russia does intend to invade India, hence she does require to pass through my country, and not only to pass through and to be anxious about her rear, but also to take Afghanistan if she can. Secondly, England is a great naval Power and does not wish to fight Russia on land unless obliged; it is therefore to England's own interest and advantage that Afghanistan should be a strong buffer state and barrier in the way of Russia, thereby keeping the two countries of Russia and England apart by land. It is consequently only natural that England desires to see Afghanistan strong and safe, to ensure her own safety and strength in India. Russia, on the contrary, being anxious to fight England on land, desires that Afghanistan should either be united with her and support her in the invasion of India, or be wiped out of existence altogether as a sovereign state. Thirdly, England has money and arms, but requires fighting men. Afghanistan has fighting men, but requires money and arms; it is accordingly to the mutual interest of Afghanistan and Great Britain that they should be combined, in which case England would have the services of the Afghans, and the Afghans would have money and arms from England. Russia can give no money to Afghanistan because she has none for her own needs, and she does not require any men from Afghanistan because she has already more than she can keep in order. Fourthly, the friendship of Afghanistan is of no service to Russia whatever, beyond allowing her to 
pass through the country to India, which means placing Afghanistan under the feet of Russia.

Russia might promise to give the ruler of Afghanistan the Punjab, or some other portion of India, and she would make friendly treaties announcing that Afghanistan should always be left independent. But such a treaty would suffer the same fate that has overtaken all the other treaties and oaths made by Russia, namely, to die a natural death the moment it did not suit her to keep to it any longer. But suppose that Russia did not break this treaty (though this would be somewhat miraculous)? In that case, also, Russia could not rule India without having her armies, officials, travellers, and others constantly going through Afghanistan to India, or from India to Russia. In this way Afghanistan would always be under the feet of Russia, who would make use of all the resources of the country, transport, provisions and the like, for her own requirements. They would impress Afghan men for their own military service, and they would put them in front wherever there should be fighting, having a double advantage in view ; firstly, by getting rid of the Afghans by their being killed; secondly; by taking possession of their wives and properties. Mahomedans, who are so strict about the reputation of their wives and families, would be unable to bear this kind of treatment, and to see the Russians making free with their country: the result of all this would be awar between Russiaand Afghanistan. At such a time, not having the help of England, thousands of men would be killed, leaving widows and orphans and country to the mercy of Russia. I do not say that my sons and successors should be hostile towards Russia; on 
the contrary, they must appear to be friendly, and, in fact, be friendly in their hearts, as Russia is a great Power, and might be of some service and help to them in the days of their trouble. It would be the very extreme of folly for the Afghans to provoke the Russians. The wisest policy to pursue is to avoid close relations with Russia, and to keep on the safe side by adopting a middle course.

If, unfortunately, the English were to change their policy and become aggressive, with the intention of annexing Afghanistan or interfering with her independence, in that case the Afghan nation would be compelled to fight against England; and, in the event of their being entirely defeated, they would join Russia, because she is much closer to the borders of Afghanistan than England is at present, and therefore in a position to support Afghanistan, which was not the case in the time of Shere Ali, she being then too far away to render him any assistance.

In fine, the poliey of Afghanistan towards her two strong neighbours should be friendly towards the one which is least aggressive, and hostile to the Power wishing to pass through her country or interfere with her independence. Afghanistan must not, however, by her actions, provoke either of her neighbours, neither must she allow either of them to enter her country under any pretence whatever, no matter what treaties or promises they make.

The poliey of the Russian statesmen who guide the movements of Russia in Asia is worthy of great admiration. The advances of the Russian political circle are like the columns of an army moving under the com- 
mand of a very capable commander-in-chief, who, having divided his army into four parts, carries on several campaigns at the same time. He arranges the four columns in such a manner that no one of the four seems to show any intention of fighting or attacking the enemy until a suitable opportunity occurs. He keeps the attention of the enemy from being concentrated upor any one point, and immediately he finds that they are becoming weak and neglectful, he attacks immediately, without giving them any time for preparations for defence.

The officials of the Russian Government are busy at the same moment at each of the four following places in the East:-Korea and China on the one side; towards Pamirs and Afghanistan on the other side; towards Persia on the third side; and Turkey on the fourth. They leave out of their calculations any other quarter, outside these four, which they see is wide awake and prepared to oppose their aggression, confining their attacks to those which are weak and neglected.

Jami, the poet, says:- "When Alexander desired to make an attack upon the East, he stationed guards at the doors of the tents of his camp, appearing to be moving towards the West." It was owing to these Russian tactics and policy that, in the time of Shere Ali, they were very actively working in Afghanistan. But during my reign, after having tried their games at Panjdeh, Kala-i-nau, and Murghab, they found that Afghanistan was wide awake, and ready to give them a warm reception, upon which they turned their attention in the direction of Pamirs. Directly they 
found England prepared to welcome them on the Kashmir and Chitral frontiers, the Russians left that point to sleep, and turned towards China. No sooner did they find that England, Germany, and France were ready to oppose their further advance at this point than they made a volte-face towards Persia.

It is possible that the Russian officials imagine that the ruling powers in Afghanistan would stop their military preparations if they thought they (the Russians) would attack India from Pamirs, descending upon Chitral, Kashmir, and Punjab, through Persia, and Seistan, and the Persian Gulf on Karachi and Quetta, and, from the Chinese direction, on Burmah and Bengal, leaving Afghanistan alone. But the Afghan people should know that by thus leaving Afghanistan alone, the Russians are only waiting for my death or some other convenient time. I am sorry to have disappointed my Russian friends so many times, and made them take the trouble to advertise my death, when I was all the while alive and very wide awake to their goings on! But they must not blame me for this, it is not my fault; I cannot die to please them, death being fixed by the Divine Will.

The Russian forces, which are being massed near the borders of Afghanistan, might be intended to move towards Persia, or, again, they might be for the purpose of frightening me, so that I might join hands with Russia against England. Again, this massing of forces might be for the purpose of making English statesmen uneasy, and to stop the movements of the English army in 
some other direction. Or, again, these warlike movements of Russia might be for the purpose of helping and bringing forward Ishak, to claim the throne of Kabul after my death. Further, they might be for the purpose of occupying Herat and Balkh at the same time that the English might be occupying Kandahar. In short, whatever their object may be in massing these troops on the borders of Afghanistan, no one can understand. I can only say that I am not a man to be frightened by any one. People who say that the Russians are going to take Herat know very little about the matter; Pussian officials are not such fools. Their memory is not so defective that they can have forgotten how, in 1837, when Herat was in the possession of the drunken fool, Kamran, who only possessed this one town, and was not the King of Afghanistan, Russia and Persia together were unable to take Herat, and had to walk away in disgrace after a six months' siege - and Herat was not conquered.

At the present moment I can arrange to mass 100,000 fighting men at Herat within a week; and Afghanistan, being well furnished with the very best war materials and fighting men, is quite prepared to show what she can do. Throughout the whole of Russian Turkestan the Mahomedan chiefs, priests, and other heads of tribes can be stirred up by me if Russia goes to war against Mahomedan countries. Considering all these points, Russian officials must know that it is impossible to attack Herat during my lifetime, because I am prepared to give them a very warm reception. 
At the other end of the North-Western border of Afghanistan the fort of Dehdadi, which I have built for the fortification and protection of Balkh, has been finished in twelve years, during which time thousands of men have been working every day. The fort is on the top of a high mountain, and commands the roads leading from the river Oxus towards the borders of Afghanistan. The fortifications of this stronghold are hidden underground, making it impossible for any heavy guns to damage the fort. The assertions of some military experts are quite true when they say that forts, no matter how strong they are, have no value in the presence of modern artillery and guns. But the naval quick-firing guns, Krupp and Hotchkiss and Nordenfeld, Maxim, and other kinds of war material which I have in these forts, are the best that can be found in any empire at the present day; and should there be any further improvements made, I shall be the first man to provide myself with them. I shall not remain far behind my neighbours in this respect.

The most probable point of attack by Russia is from Merv and Ashkabad upon Herat, which commands the road to Kandahar and Quetta, and from the direction of Tashkend and Samarkand on Balkh, which is on the road to Kabul and Peshawar, and from Badakshan on Faizabad and Kataghan. Should Russia, however, contemplate attacking both Afghanistan and India at the same time, their attack would be made from the Pamirs upon Wakhan, Chitral and Kashmir. It is also possible that at some future time Russia might find some loophole for attacking India through Burmah and through Persia. 
When Russia approached near to Panjdeh I made the fortifications of Herat stronger than they were before. Upon this Russia showed more signs of activity towards Balkh, which place I had also strongly fortified. She then turned her attention towards Badakshan and Pamirs, to answer which challenge I conquered Kafiristan and, having cut roads from Jellalabad, Lamkhan, Kabul, and Panjshir, prepared myself to meet the Russians in that quarter also. In 1893 I told Sir M. Durand that I could not protect Wakhan against Russian aggression if the English intended cutting away Chitral and Bajaur from me: I accordingly left Wakhan to the responsibility and protection of the English. Now that the Russians are exhibiting activity in the direction of Persia, it is necessary that I should pay earnest attention towards the South-Western borders of Afghanistan, which lie between Herat and Kandahar. So in this way, no matter in what direction the Russian statesmen move their forces, I, having been informed by my spies, send double the number of soldiers to be ready for them whenever they come too near. I also pay, and keep at my Court, the former rulers of Badakshan, Darwaz, Kolab, Roshan and Bokhara, and I have appointed the sons of the Mirs and chiefs of the Turkomans as my special body-guard, thus winning their hearts and cementing the friendship between us. This policy will prove of the greatest service at any time of Russian aggression; though I am sure that, so long as I live, and Russia knows that Afghanistan and England are united, she will never attack Herat or any other part of Afghanistan. For all this, the 
Russians continue to mass their forces near the borders of my country under the pretence that they are for the protection of their own subjects in the event of disturbances arising in Afghanistan at the time of my death! Just as if my death should be the signal for the Afghans to attack and invade Russia! It is therefore only reasonable to suppose that I also should continue to mass my forces near the Russian borders, so that if the Russian Mahomedans or other discontented Russian subjects disturb the peace in Russia by a general rising, my forces will be ready to keep the peace by the moral force which always attends upon the possession and exhibition of a strong army against a greedy enemy watching outside.

I say, with certain knowledge, however, that it is not the present policy of Russia to go to war with either England or Afghanistan, the Russian Government not being prepared for such a war. The Russian policy is to keep on moving forward slowly, firmly but constantly, taking one bit of country after another from those lands they find too weak to protect themselves from their encroachments. This is the policy that Russia intends to continue, for the purpose, by slow progress, of joining her borders with those of the Indian Empire, from one end to the other. This accomplished, she will go to war with England. Such being the case, many years must elapse before this Russian scheme can be brought to full fruition, and many things may happen in the meantime to prevent a war taking place between Russia and England.

It is only from the optimistic point of view that voL. II. 
it is argued that Russia could not and would not attack an united India or Afghanistan; so we must not lull ourselves into a false lazy security; it would be an unwise and near-sighted policy not to be fully prepared for any emergency that might arise from the Russian aggressive policy.

I could make many suggestions for stopping and putting an end to this aggressive policy of Russia towards India and Afghanistan, but I will confine myself to giving only a few necessary hints now. The first and most important one is what I have before emphasized, viz., that England and Afghanistan must be firm allies: while such an alliance continues Russia will never attack either of them. Englishmen who say, "Why should we go to war with Russia for the sake of Herat or any other part of Afghanistan?" do not know that to fight for Herat, which is the key to India, is in reality to fight for India itself. If Russia were to take Herat and Afghanistan, she need not trouble much about attacking India, because it would be very difficult for England to rule in India, when her borders should touch those of Russia, necessitating the presence of a very large army, larger indeed than the Indian Treasury and Exchequer could afford to keep. Many more grave complications and difficulties would arise from having Russia as a close neighbour of India. At a time, too, when the brave fighting races of Afghanistan and Turkomans were standing and fighting under the Russian flag, it would require an immense army on the part of England to defend herself and her possessions. If England has no intention of breaking her faith and 
treaties (which I am sure she has not) that she has made with my Government to protect Afghanistan against Russian aggression, and if she does not desire to go to war with Russia merely upon the question of Herat, then Englishmen should not make public statements of this policy, beeause if Russia ever did attack Afghanistan it would be for the purpose of invading India. As long as Russia knows that the unanimous desire of Englishmen and that of the Afghans is to stand and fall together, she will never attack either the one or the other, knowing well that the two combined are too strong for her.

The second hint is: Russia will never stop moving forward till England stops her. If England wishes to put a stop to this aggressive policy, she herself must cease to practise a weak, apathetic, indifferent policy towards the movements of Russia, such as has been carried out by past English politicians. If Russia is once made to understand that any further aggression on her part would be the cause of war, she would be easily turned back by a strong protest. I know well that at the present moment Russia is not prepared, nor is she desirous of going to war against England, but so long as the English exhibit silence and indifference towards Russian aggression, so long will the Russians continue their slow movement forward. If Russia occupies or takes under her influence any one of the three countriesAfghanistan, Persia, or Turkey-it would injure the other two as well as affect India. Therefore her aggression should be opposed when it is turned against any one of these countries. Sadi says: "When a 
spring of water first breaks through a small hole, it can be stopped by a finger being placed upon the hole; but it cannot be stopped by putting an elephant before it when it is too large to be stopped."

The third way of stopping Russian aggression in the direction of India is for England to make Afghanistan strong by giving her every help in the shape of money and war materials, and to show Russia in plain and unmistakable language that during my lifetime, as well as after my death, any interference in the affairs of Afghanistan, or putting forward claimants for the throne of Kabul, would mean war between Russia and England.

Afghanistan neither needs nor does she desire that the English army should enter the country at any time under any excuse of fighting against Russia, or the like, so long as we have sufficient money and arms. The only time that the Afghans would willingly admit the English army into their country would be when they had been decisively and officially defeated by Russia, and could not stop her from taking their country by any possible means. But as long as the Afghans can fight for themselves they ought not, and they would not, let one soldier of Russia or England put his foot in their country to expel their enemy, as it would be impossible to get rid of the army which they themselves had invited to help them, who would always have the excuse for remaining by saying that they were keeping the country peaceful. In such a case, if they found that the country was peaceful and the people contented under their rule, they would remain there. If the people rose against them they would say: "As you have broken the 
peace, the promise we made that we would return the country to you does not hold good any more."

If England and Russia were to agree to divide up Afghanistan between them, they may make certain that this would be the foundation of a war between them in India, that would soon come to pass after such a treaty had been entered into. In the ease of such a division, Balkh, Turkestan, Kataghan, Herat, and Farah, countries lying on the west of the Hindu Kush, would come under the Russian division; they are the richest and most fertile provinces of Afghanistan, whilst those of Jellalabad and Kabul, falling to the share of the English, are scarcely rich enough to pay their expenses. It is a great mistake that suspicions should exist in the minds of British statesmen about my friendship: when the English find that the ruler of Afghanistan is wise, strong, and loyal, it is their duty and interest to support him: a weak, inexperienced, and untrustworthy Amir on the throne of Kabul would be dangerous for Afghanistan as well as for India.

My fourth suggestion is that the English should not neglect Persia and Turkey, as they have done in the past few years; they must prevent both these countries falling into the hands of Russia, or under her influence: they must do their utmost to make Persia and Turkey strong, and endeavour to win their friendship. In accordance with my suggestion mentioned elsewhere, England must also take steps to help Persia, Turkey, and Afghanistan to enter into a triple alliance, which means erecting a strong wall in the face of Russian aggression, by the union of the whole Islamic world. This would result in a general and universal peace 
throughout the whole of Asia where Russian aggression is going on, and which threatens a most serious war in the future. It is quite obvious that if these three Islamic Powers, who are bound to each other by ties of religion, and whose safety lies in their being friendly allies, were friendly to England, the whole Islamic world would be bound to look after British interests.

My fifth suggestion is, that it is necessary for both England and Afghanistan to maintain the strength of their forces: they should work towards making their subjects rich and contented, keeping an army sufficient to oppose the advance of an enemy; just as taking a tonic is better than taking medicine after falling ill. As one of the poets says: "Show preparations for war if you wish to keep the peace, and to educate, enrich and please the subjects makes the foundation of the kingdom strong, as the subjects are the walls on which the building of the Government stands."

The welfare of Afghanistan can best be achieved by promoting industries, and improving trade and commerce, and thus keeping the subjects well employed, whereby they can earn comfortable livings. Another means is bringing about social intercourse between the ruling nations and the ruled, and by studying the feelings of the people, redressing their grievances, and giving them all equal rights, without any distinction of nationality, caste, colour or creed. I admire one point in the Asiatic policy of Russia, that in Russian Turkestan their RussoOriental subjects also rise to the positions of colonels and generals, while intermarriage and social intercourse between the two races are much more frequent than 
between the Anglo-Indians and the Indians in India, who are always aloof from each other. If an English person marries an Indian the whole English community looks upon the couple with prejudiced eyes and contempt. The result of this is, that the English and the Indians are not in the position of studying each others' feelings, and remain utter strangers to each other. There is another regrettable circumstance in India, namely, that the friendly intercourse that used to exist between the old English officials and the Indians in India is on the decline, because the newly-educated young civilians who come to India from England, having passed their exams., but having no experience of the world and of life, look upon their term of service in India as a temporary measure, and owing to the easy means of travelling between India and England, they can more frequently visit their friends in England, and therefore do not care about making friends in India. The old Anglo-Indians used, on the other hand, to settle down in India, looking upon it as their home, and so were bound to seek society and friends among the Indians themselves.

After having stated the probability of a Russian attack upon India and Afghanistan, and the means of stopping such a plan, I will try to explain how far the Russians are wrong in their ideas, and whether their invasion of India is possible or not.

In answering this question I am very sorry to disappoint my Russian friends, from whom I received much courtesy and hospitality; but I must honestly tell them that so long as Afghanistan does not join Russia, the invasion of India is impossible, and the 
joining of Afghanistan with Russia in such an invasion is still more impossible. If the Russians would take my advice, as their true friend-and I really give them honest advice, as I am under heavy obligations and owe them a debt of gratitude-they must not try this game. The result would be the ruin of Russia, and is sure to end like the following story:-A man was very thin, and his wife was anxious that he should become a little stouter. This man was very fond of playing with wasps' nests, though his wife had often told him not to do so. It happened one day that the irritated wasps attacked him, and stung him most fearfully. When he reached home he was quite swollen, and stout and full in the face. His wife, who was very pleased at this change in his appearance all at once, asked him how he had managed it. $\mathrm{He}$ answered that he had been bitten by wasps, and that he was in terrible pain. His wife began to pray: "O Lord, make the pain go, but let the swelling remain!" But, unfortunately, the contrary was the result; the swelling soon went down, but the bloodpoisoning remained. This will be the end of Russian attempts to invade India: that they will not be able to take India, and the pain and sufferings of the terrible war would remain to add to their sorrow.

If any future ruler of Afghanistan should join Russia in her plans of invading India, the friendship and support of such an Amir would be of far greater importance than that of any other Empire, for the reason that he is such a close neighbour of India. But as I have clearly explained above, such a combination is quite impossible, and is a most delicate and difficult problem. Should, 
however, any future Amir be so foolish as to invite Russia or England to occupy his country or to pass through it, the result would be the same as it was in the time of Shah Shujah, when the Afghans killed the Shah as well as the English who had been invited by the Shah to enter into their country. The English Government, having tried two experiments, do not want to try a third; and if Russia is wise she will learn a lesson from the expenses and pains and sufferings of the English, and not interfere in Afghan affairs, even if the Amir of Afghanistan should invite them to do so.

By glancing at the map of Afghanistan, it will be seen that before 1816 and the reign of Shah Shujah, after which the English began to interfere in Afghan affairs, Kashmir and the other frontier districts which now form part of the Indian Empire, were all under the rule of my predecessors, and have been taken by the English bit by bit at times of difficulty and disputes, and deaths of the successive Amirs of Afghanistan. They never failed to get hold of some part or the other whenever they found a favourable opportunity. For example, the poliey of Lord Lytton in separating Chitral, Yasin, and Kalat from the influence of Shere Ali was this, that Afghanistan should be eut up into pieces and divided up into small States, in order to weaken the country. Then the English took from Yakub, by the Gandamuk Treaty of 26th May 1879, Pishin, Sibi, Kuram, Shinwari, Khyber, and Peiwar Kotal.

The whole of the most southern part of Afghanistan, which lies towards the south of the Upper Scinde boundary, has been taken by the English in the past years in carrying out their so-called "Forward Policy." 
This has been done at a very heavy expense to the Exchequer of poor, starving India. This part is now called British Baluchistan, though 90 per cent. of the inhabitants are Afghans, and only 10 per cent. Baluchis.

The English, gradually crawling forward, have taken Bajaur, Dir, Swat, Nawaji, Bulund Khel, Chagai, Waziri, and New Chaman. The Indian Government was furious at me for refusing to leave Asmar, Mohmand, and Kafiristan also to them. They did not understand that, as much as the Indian territories and boundaries are pushed forward from the old wisely-marked boundary line called the "Lawrence" line, the expenses of keeping this long line safe are far heavier than the Indian Treasury can afford to pay. The line is in far greater danger in the case of foreign attack than was the former one.

The Russian policy of aggression is this: to attack the weak country, leaving the strong one alone. For instance, twenty-five years ago, finding a suitable opportunity, she fought with the Turks, after which she turned her attention to Afghanistan, and as soon as she found that that country was placed under a strong Amir, and that the eorner of Kashmir and Chitral was neglected, she occupied Pamirs; when the English fortified Kashmir and Chitral in her face she then turned her attention towards China and Persia. Meanwhile, she is anxiously watching for an opportunity of attacking Afghanistan after my death or upon some other suitable occasion.

If Russia should make war against the combined forces of England and Afghanistan in the following manner, namely, sending columns of the Russian 
army through Pamirs to attack Kashmir and Chitral, and through Badakshan to attack Faizabad and Kataghan, and through Samarkand and Tashkend to attack Balkh, or through Merv, Ishkabad and Kushk to attack Herat, or through Persia to attack Kandahar and Quetta; it is obvious that such a step would mean a long costly war, necessitating the dividing up of the Russian army into many portions. As Russia requires a strong force on the borders of China and Japan, Austria, Germany, and Turkey, as well as to keep her own country safe from general risings and disturbances of the Mahomedan Turkomans and other discontented subjects, a very small number of men would be available for each one of these campaigns to be carried out at so many different points, and so far apart from each other. For this purpose Russia has neither sufficient army nor sufficient money, provisions or transport.

We will suppose that Russia eonfines her attention to an attack upon Herat and Balkh and the borders of Afghanistan. In such a case, though I do not give the number of my army, yet I will say for certain that I do not require any English army to enter my dominions; I only know that if England bombarded and attacked Russia in Europe, the number of her army would not be sufficient to face mine, and at the same time to fight against the Muslim ex-rulers and chiefs of Kolab, Darwaz, Badakshan, Shignan, Roshan and Bokhara, who are at my Court; and who, through their relatives and friends and influence, would make it very hard for Russia to keep her own subjects quiet. 
Let us suppose again that England, in the face of her standing treaties, refused to assist Afghanistan against a Russian attack upon Herat or Balkh. I think the Russians believe that (as happened on their occupying Panjdeh in 1885 when the English did not fight with them) the result would be the same if they occupied Herat or Balkh. But my Russian friends are mistaken in such a belief: the Afghans would not consent to leave Herat or one inch of their country to Russia so long as one man remained alive to fight; and in the event of their failing to expel the Russians, they would offer Afghanistan to England. Should the combined forces of England and Afghanistan be defeated by Russia at Herat and Balkh, they would make their second stand and line of defence at Kabul, Ghazni, and Kandahar, and their third line of defence would be from Quetta to Peshawar and Chitral. In all these cases the English and Afghans have the advantage of fighting in their own land; of bringing every soldier and every peasant and farmer of Afghanistan to fight against Russia. Russia would be under the same disadvantage as was Henry I. of France at the time of the war between France and Spain: if too large an army were sent the men would die from scarcity of food, and if they sent too small an army it would be conquered by the enemy. Another advantage on the side of Afghanistan and England is this: if they are defeated on their first line of defence they have their second and third lines to fall back upon, and there make a stand. It would be a very fatal step on the part of Russia to attempt to cross such an 
immense distance, leaving her rear at the mercy of the Muslim population of Afghanistan and the Turkomans. If Russia were defeated, her vast Empire, the fibres of which are knitted together by force and not by love, would fall to pieces in such a manner as by pulling the thread of a necklace all the pearls fall apart from each other and are scattered. Russia, in fact, has no chance of continuing her fighting advance as far as the Scinde line, which would require thousands of millions of money and years of fighting. Russia could not afford this on account of the poverty of her country, and the difficulties which would arise within her own dominions behind her.

In any case, it would be to the advantage of the English for hostilities to commence at Herat, if they commence at all. In this case, the Afghans, supported by English arms and money, would fight in Asia, leaving European Russia to England. The policy of England should be to fortify, not only her Indian frontier against Russian attack, but to avoid such attack altogether, by fortifying and strengthening the Afghan frontier in the face of Russia.

Now, supposing, though it is not possible, that the English people were so foolish that, in the event of the Russians occupying Herat and Balkh, they should occupy Kandahar, Kabul, and Ghazni, without the consent and invitation of the Afghans, instead of expelling the Russians from Herat? Such a policy would be dangerous for Afghanistan and India equally, because Afghanistan would be cleared out of the way of Russia, and the Afghan people, 
being offended by England breaking her faith with them, and forgetting her promise to help Afghanistan, would come under the influence of Russia. This would mean an offensive alliance between Russia and Afghanistan against England. Russia would have the advantage of occupying the most fertile and richest provinces of Afghanistan, which lie on the North-Western side of the Hindu Kush, i.e. Turkestan, Kataghan, Farah, and Herat, leaving the South-Eastern provinces of the Hindu Kush, from Peshawar to Jellalabad and Kabul in the English division, which are the most barren and uncultivated. If, in such an event, Rusșia and England made a treaty between themselves, agreeing to divide Afghanistan, the Indian exchequer would be unable to pay for the fortification and safety of these new lines of defence, and the treaty would be a foundation, laid by Russia, in order to gain time to prepare for further attack on India.

But praise be to Allah! both the English and the Afghans have sufficient sense to understand that their safety and strength lie in being united, and their danger lies in disunion.

In the history of every country there comes a stage when the old school of politicians finds itself in contest with the new and progressive. If the Government of such a country passes through the crisis safely, the country becomes stronger and more civilized; should, however the Government try to crush down all the efforts made by the people to obtain more freedom of thought, and action, and expression, the nation sinks into a condition of weak- 
ness and discontent. Such a stage in her history has been faced and passed by England. India was in the same position a few years ago, which stage is now happily passed over. To-day the well-informed, intellectual Indian, educated on modern lines and according to the English methods, is keenly alive to the advantages of British rule as against that of Russia.

Whilst admitting that England has not such a large standing army as Russia has, I must remind my Russian friends of the words of a great General, Napoleon, who said: "It can never be known when the English are beaten." Why? Because the British subjects are so devoted and loyal, that no matter how many times the British army meets with reverses in which large numbers of their countrymen are killed, the more does their spirit of loyalty and enthusiasm and support of their Government, mingled with a desire to erush the enemy, increase in their mind. This feeling is not confined to the British Isles alone, it extends to every one of her colonies. They send one reinforcement of volunteers after another to support the Mother country, until at last the enemy is signally defeated and cannot recover himself to fight any more. So much may be said, that though the British Government has not a large standing army, yet every individual British subject is ready to fight under the victorious flag in her army. Therefore the whole population of the British Empire, which is ten times more in number than that of England, can be calculated upon as forming a reserve force to call up, or who will voluntarily 
304 ENGLAND, RUSSIA, AND AFGHANISTAN [снAP. viri.

come forward to form part of the British army in time of war. The English could thus continue a war for which they have plenty of money, arms, and men, till at last Russia's resources for providing for her army are exhausted, and the victory would fall to the English, as has always been the case in every great battle that England has fought against Russia, France, or other foes.

THE END. 


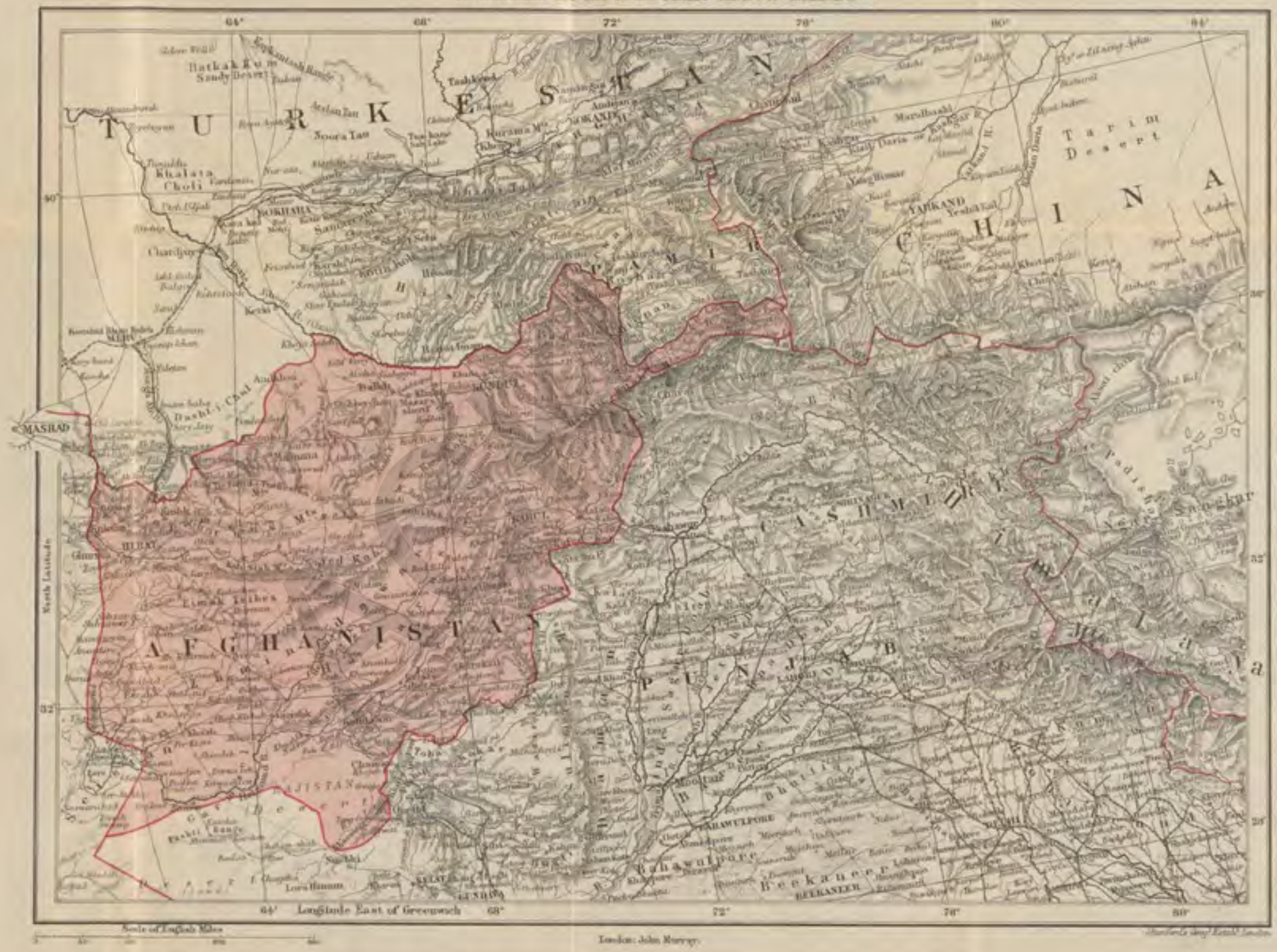




\section{INDEX AND GLOSSARY}

Abdul Ghais Khan, i. 28; death of, 28,34

Hákim Khan, i. 267

Karim, Mullah, i. 258

Kudus, i. 177, 206; captures

Herat, 215; defeats Hazaras, 280

- Rahim Akhund, Kakar, killed by Abdur Rahman, i. 216

Rauf, i. 44

Shakur, physician, i. 266

Abdulla Ansar, wise saying of, i. 263

- Jan's mother's complicity in Cavagnari's murder, i. 152

Khan, i. 145, 160, 169; marches against Ishak, 268; defeats Hazaras, 283

Abdur Rahim Khan, jealousy of, i. $4 ; 6,7,49,51,74$, in action, 80 , 81 ; devotion of servant of, 110

Abdur Rahim Khan, physician, ii. 70

Abdur Rahman, Amir, first journey to Balkh, i: 1; joins his father, 1 ; appointed viceroy of Balkh, 2; daily routine at Tashkurgan, 3; resigns governorship of Tashkurgan, 4; becomes engaged, 4; receives military instruction from an Englishman, 5; imprisoned, 6 ; released, and appointed commander-in-chief, 7 ; captures Ghori fort, 13; leniency toward prisoners, 13; subdues Badakshanis, 17; narrow escape of, 17 ; subjection of Badakshanis, 20; leaves for Khanabad, 22; rescues a gun, 23; visits tomb of saint in Tashkurgan, 25 ; inspects arsenals, 25 ; adventure with camel, 26; winters in Taktapul, 28; conspiracy against, 30 ; victory at Narin, 31 ; subjugates rebels, 33 ; answer to Jahandar Shah, 35 ; submission of Jahandar Shah, 37; vision of, 37 ; inspired to read and write, 39 ; subjugates Kolab, 40; receives father at Khanabad, 44; intrigues of father, 44 ; sent to Taktapul, 45 ; counsels seizing of Shere Ali, 47; joins his father at Mazar, 47; desertion of army of, 48 ; flies to Bokhara, 48; arrives at the Oxus, 50 ; crosses Oxus, 51 ; journeys to Bokhara, 53 ; receives presents, 54; received by Amir of Bokhara, 55 ; refuses service, 56 ; incident at prayers, 58 ; proposes to meet Mahomed Azim at Balkh, 59; at Shinabad, 65; crosses Oxus, 65 ; defeats Shahabdin, 67 ; goes to Bamian, 69; arrival of uncle from India, 69 ; advances on Kabul, 71 ; returns to Kohistan, 71 ; captures Kabul, 72; reaches Ghamni, 72 ; retires to Saidabad, 74 ; stratagem of, 74; defeats Shere Ali, 76 ; joined by his father, 76 ; readiness of army under, 78; advances to Ghazni, 78 ; victory of Chashma-i-Panjak, 79; order of march, 80 ; Battle at Kalat-iGhilzai, 81; enters Kandahar, 83; summoned to Kabul, 85; nurses father in cholera, 86 ; defeats Faiz Mahomed, 87; intrigue against, 89 ; sent to Balkh, 90 ; captures Nemlik fort, 92 ; leaves for Maimana, 94; captures Mai- 
mana, 96; helps Amir Azim, 97; starts for Kabul, 97; reaches Ghori, 98 ; advances to Ghazni, 99 ; accuses his uncle, 101; escapes to Waziri hills, 104; loss of property, 105 ; a wanderer, 106 ; deserted by followers, 107 ; enters Waziristan, 108; incident of cooking pot, 109; receives assistance, 110; receives message from Englikh, 110; halts at Kaniguram, 111 ; enters Zhob, 112 ; adventures with an impostor, 113; adventure with robbers, 114; meets the "King of Devils" 119; arrives at Pishin, 120; at Nushki, 120 ; distress at Chagai, 121 ; reaches the Helmund, 122; story of Shah Gul, 122, 123; troubles with Hazaras, 125; visits Mir Alam, 125; crosses Lut desert and arrives at Birjand, 126 ; advances towards Mashhad, 126 ; kindness of Kazi Hassan Ali, 128; arrives at Mashhad, 129; invitation from Shah of Persia, 130; at Ishkabad, 131; lost in desert, 133 ; reaches Khiva, 134; proposals of the Khan, 135; refuses Khan's offer, 136; sees King of Bokhara, 139; received by Russians, 139 ; entertained at a party, 140; invitation to Petersburg, 141; arrival in Samarkand, 143; exile in Samarkand, 144, et seq.; sons born, 146; dealings with Russians, 148; unfriendliness of Russians, 153 ; taken prisoner by Russians, 156; ordered to Taskkend, 157; despondency, 158; reception by General Kanffmann, 159; starts for Afghanistan, 160; vision of, 160; kindness of Russian Colonel, 161 ; a cold march, 165 ; dream of Khwaja Ikrar, 166; letter to Amir of Bokhara, 167; at Yakobagh, 167; traverses Hissar, 169; crosses Oxus, 170 ; letters to Shahzada Hassan, 170; religious convictions, 171 ; advances against English, 173; wins over Badakshanis, 173 ; preaches a holy war, 174; plot of Mir Baba against, 178; arrives at Faizabad, 179; adventure with Mir Baba, 181; plots of Sultan Murad and
Mahomed Omar against, 183 ; arrives at Talikhan, 184 ; joined by the armies, 186 ; receives money and support, 188; releases women prisoners, 189 ; receives letter from British, 190; letter to Lepel Griffin, 193; advances towards Kabul, 195; proclaimed Amir at Charikar, 195; negotiations with the English, 196; agreement, 197; wishes English God-speed, 198; assists departure of English, 199; established on throne, 199; marries, 201; collects money and stores, 204; anxious position of, 208; defeats Ayub at Kandahar, 215; kills a mullah, 216; returns to Kabul master of Afghanistan, 217; feelings of responsibility, 220; difficulties of, 223 ; dream of, 231 ; arrives at Jellalabad, 237; punishes Shinwaris, 238 ; attack of gout, 266 ; reported death of, 267 ; sends expedition against Ishak, 268; visits Turkestan, 271; narrow escape at Mazar-i-Sherif, 273; anxiety concerning Roberts' mission, 282; reasons for invasion of Kafiristan, 288; intends fortifying, 291; policy towards refugees and rivals, 294,295 ; roL. II., reasons for not naming successor, 2 ; provisions for education of youths, 18; love of engineering, 20; sturts workshops, 23 ; in defence of his expenditure, 45 ; daily life of, 79 ; illness caused by mental activity, 82 ; despair of ultimate success, 83; personal work of, 86 ; courtiers of, 87,88 ; bodyguard of, 89,90 ; page-boys, 91 ; food and meals, 94,95 ; allowances of household, 97; leisure moments, 106; linguistic knowledge of, 107; chosen Amir of the people, 113; appreciation of Anglo-Afghan union, 115,116 ; desires eloser relations with English, 118; desires interview with Lord Ripon, 121 ; meets Lord Dufferin at Pindi, 128 ; warnings neglected, 131 ; appreciation of Indian army, 131: impressions of India, 132, 133; wiahes to visit England, 133; becomes alarmed at Lord Lans- 
downe, 136 ; annoyance of, 137 ; Lord Roberts' mission threatened, 138 ; appeals to Lord Salisbury, 138; desires a representative in London, 140; invited to England, 140; illness of, 141; disappointed at failure of Nasrullah's mission, 142 ; prophecy as to frontier tribes, 157; preaches nnion, 178 ; books published by, 204; hopes of future prosperity, 206, 212; hints to his successors, 237 ; attitude towards foreigners, 239 ; reputed ernelty of, 240 ; justification of his conduct, 241; son disant representatives of, 255 ; experiences of Russian duplicity, 271 ; advoeacy of a strong Afghanistan, 277; checkmates Russia, 288; unworthy suspicions against, 293 ; advice to Russia, 296

Ab-i-Kali, i. 85

Abramoff, General, i. 142, 143, 145, 146 ; wounded, 147

Abu Bekr, i. 232

Adam Khan Waziri, kindness of, i. 109

Administration, i. 200

Afghana, ii. 113

Afghanistan, conditions of, at Abdur Rahman's accession, i. 22 ; future of, ii. 165 , et seq.; consolidation necessary, 169 ; strength of; 172 ; useless to outsiders, 173; historical sketch of, $215,218,219$; various attitudes of powers towards, 239 ; a free Muslim power, 244 ; varions English policies towards, 252, 253; preparations for defence of, 288 ; lines of defence of, 300

Afghans, their views of English relations, ii. 113 ; origin of, 213

Afzal Khan, British Agent at Kabul, ii. 162

Afzul (Amir), father of Abdur Rahman, i. 1 ; joined by his son, 44,47 ; prisoner of Shere Ali, 61 ; death of, 86,87

Agreement between Abdur Rahman and the English, i. 194, 196, 197

Aggressions of Russia, on the Pamirs, i. $285,286,289$; ii. 123 , 291; of English, ii. 237, 297

Ahmad Kashmiri, i. 44
Ahmad Khan, elected Amir, ii. 216 215

Aibak, i. $68,90,97$

Aishak Akasi (court secretary), ii. 87

Akcha, i. 64, 65, 66, 91

Alam Gunj, site of the factories at Kabul, ii. 23

Alexander the Great, i. 235 (note), 277 ; ii. 214,284

Alikanoff, General, i. 140

Ali, Mahomed's son-in-law, i. 272 ; ii. 115

Ali Askar Khan, General, i. 64, 68, $84,110,112$

- Murtza, tomb of, i. 2

- Yar Khan, i. 130, 131

Allan's "Diary of a March through Scinde," quotation from, ii, 224

Amir Ahmad Khan, i. 7 ; death of, 272 ; ii. 134

Amir Mahomed Khan, conquers Hazaras, i. 283; honours of, 284

Andarab, rebellion in, i. 14 ; subjection of, 15

Andkhoi, i. 91, 93, 188

Anglo-Afghan relations, ii. 111, 115, 119 ; growth of friendly, 257 ; advocacy of common interests, 280,281 ; advocacy of an alliance, 290 ; strength of a combination, 300

Anglo-Indian exclusiveness, ii. 295 Anonymous letter, i. 178

Ansar, ii. 188

Anxiety of Abdur Rahman, ii. 242

Arbab (the headman of a town or village), ii. 188

Arg, the palace at Kabul, ii, 61

Arghastan, i. 79

Arms, necessity of supplying Afghanistan with, ii. 28, 191 ; importation of, prohibited, 136 ; sanctioned, 162

Army of Afghanistan, loyalty of, i. 27 ; former state of,ii. 56 ; present efficiency of, 57 ; need of officers, 59 ; mobility of, 192 ; pay department, 195 ; promotion in, 196

Arzbegi (an official who announces complaints at a durbar), ii. 88

Ashan (Turki word for a priest), treachery of an, i. 17.

Aslam Khan, Colonel, ii. 152

Aslam Khan (Abdur Rahman's uncle), i. 42, 44 
Asmar, ii. 158; ocempation of by Ghulam Haidar, 159 ; its importance to Afghanistan, 159

Asmtullah Khan, i. 251

Astrologers, ii. 23

Ata Gurh, Hotaks defeated at, i. 257

Auchi Pass, i, 164

Andiences of Abdur Rahman, procedure at, i. 240 (note)

Ayesha, the wife of Mahomed the prophet, ii. 211

Ayub Khan, defeats British at Maiwand, i. 196; officers of, 211; vietory at Karez, 211; captures Kandahar, 212; mistakes of, 213; defeated by Abdur Rahman at Kandahar, 214; flies from Persia, 260 ; his supporters now at Kabul, 294

Azim din Khan, i. 72

Azim Khan, i. 10, 43, 50

BADAKsHAN, fighting in, i. 17 ; rebellion of Mirs of, 19; reconciliation, 25; present from Mirs to Abdur Rahman, 27; disturbances in, 29; isolation of, 235 (note)

Baghdad, i. 235 (note)

Baghlan, i. 11

Bajgah, i. 45,69

Bala Hissar (the High Fort or palace), i. 86 (note)

Balkh, Abdur Rahman's arrival at, i. 1, 43; affairs in, 84 et sequ.; Mirs of, fly, 91, 96; death of Shere Ali at, 152

Baluchistan, British, ii. 298

Bamian, Abdur Rahman arrives at, i. 69,84 ; statue of Budda at, 268 (note)

Barakzais, origin of, ii. 215

Barat (Mahomedan Id or festival), ii. 108

Bawina Kara River, i. 4

Beard, pulling of the, i. 225

Bimao, i. 163

Birjand, i. 126

Birmal, i. 105

Blood, the price of, i. 227

Bodyguard of Abdur Rahman, ii. 89

Bokhara, Mir Muzaffar, King of, i. 21 ; flight of, 24 ; sends envoy to meet Abdur Rahman, 51; welcomes Abdur Rahman, 53, 55; at prayers, 58; grants Abdur Rahman permission to leave, 59 ; conduct of, 65 ; cruelty of, 138 ; correspondence with Abdur Rahman, 167; plots against Abdur Rahman, 179

Bokhara, Abdur Rahman a state prisoner in, i. 56 ; banquet at, 57

Books published by Abdur Rahman, ii. 204

Boot-making factory at Kabul, ii. 40

Bosaga, i. 24

Boundary Commission, the RussoAfghan, i. 241 ; ii. 151

British Government, cold treatment by, i. 69 ; assurances valueless, 243 ; refnses to help, 286

British subjects, loyalty of, ii. $\mathbf{3 0 3}$

Brown, Mr, electrical lighting engineer, ii. 31.

Bulund Khel, ii, 158, 237

Burnes, Sir Alexander, ii. 230, 231, 232

Camrron, Mr, superintendent of rifle factory at Kabul, ii. 34

Campbell becomes a Mahomedan General, i. 4 ; ii. 55

Canals, advoeation of, ii. 207

Candle and'soap factory at Kabul, ii. 42

Cartridge manufacture at Kabul, ii. 32,33

Cavagnari, Sir Louis, i. 151 ; murder of, 152,175 ; ii. 118,186 ; blunder of his mission, 236

Centralisation, evils of, ii. 50

Chabutra (the office of the tax collectors), i. 209 ; ii. 65

Chagai, i. 121 ; ii. 298

Chageh, ii. 159

Chahar Yar (the four friends of Mahomed), a war cry, i. 12, 192; ii. 55

Chal, i. 19, 21

Chaman-i-bed, ii. 153

Chaman, new rail head at, ii. 135, 159

Chamkani tribe, ii. 215

Char-i-bardar (tea-bearer), ii. 87

Charikar, i. 21, 72, 86; Abdur Rahman proclaimed Amir at, 195

Charki, i. 21

Chashma-i-Panjak, affair of, i. 79 
Chasma-i-Shir, i. 11

Chilak Sarabad, i. 66

Chishtia, mystic sect of, i. 264

Chitral, Abdur Rahman's uncle passes through, i. 70

Christian missionaries, i. 289, 291

Christmas party, a Russian, i. 140

Clements, Mr, superintendent of stud of horses at Kabul, ii. 74

Coinage, i. 203; old and modern, ii. 31

Commerce, ii. 75, 170, 207, 208

Concessions not to be given to foreigners, ii. 209,210

Connaught, Duke of, ii. 9, 128 ; meets Abdur Rahman, ii. 130, 132

Conservatives and Liberals, i. 245

Constitutional Government, ii. 187, 188

Council toelect King of A fghanistan, ii. 216

Cross, Lord, ii. 138

Curzon, Lord, visit to Abdur Rahman, i. 246 (note); ii. 8 ; visit to Kabul, 141; quotation from, 222

DADe of the Sala Khel tribe, i. 237

Daftar Hisal Giri (the accountant's office), ii. 102

Daim Khan, Dr, ii. 70

Daly, Mrs, nurse at Kabul, ii. 70

Dand-i-Aba Istadah, i. 257

Daolatabad, i. 48

Darah-i-Yusuf, i. 47

Daragaz, i. 131

Daud Shah Khan, connected with the murder of Cavagnari, i. 152

Dawa, i. 109, 111

Dehdadi, murder of Sarwar Khan at, i. 177 ; the new fort at, ii. 69,135 , 287

Deh-i-sabz, i. 152

Dewalak, action at, i. 80

Dihafshar, Hazaras rebel at, i. 282

Dihbring, i. 112

Dilawar Khan, rebellion of, i. 234; subjugation of, 240

Distillery, establishment of, at Kabul, ii. 37

Dodah Mast, fort of, i. 72

Donald, Mr, ii. 160

Dost Mahomed, Amir, burial place of, i, 42; his loyalty to England in the Mutiny, 69,70 ; ii. 4,220 ; unmerited deposition of, 234 ; reinstatement and death of, 235

Dost Mahomed the "King of the Devils," i. 119

Dream of Abdur Rahman, i. 231; ii. 81

Dress reform at Kabul, ii. 43

Dufferin, Lady, Abdur Rahman's appreciation of, ii. 132; work in India of, 134

Dufferin, Lord, i. 246; interns Ayub, 260 ; ii. 21 ; appreciation of, by Abdur Rahman, 128; meets Abdur Rahman, 128; durbar at Pindi, 130; departure from India, 134, 154

Durand,Sir Mortimer, i. 236; mission of, 286 ; treaty with, 287 ; ii. 30 , 140; mission of, 145, 155; Abdur Rahman's appreciation of, 160; personnel of mission of, 160 ; success of mission, 161; festivities for, 162 ; bestowal of medals on, 163 ; 237,288

Enucation in Kabul, ii. 46, 74; of children, 98 ; of women, 198

Edwards, Mr, engineer, at Kabul, ii. 33

Ellis, Colonel, ii. 160

Elphinstone's "Account of the Kingdom of Caubul," quotation from, ii. 226

Encroachment of English and Russians on Afghanistan, ii. 123, 148, 237, 297

English, Abdur Rahman's message to, i. 111 ; position at Kabul, 195 ; flight of, to Herat, 244; object of employment in Kabul of, ii. 24; advantages of an English-Afghan combination, 58; identity of English - Afghan interests, 60, 115 ; promises to support Abdur Rahman, 126; Abdur Rahman's warning to, 180, 181; lessons to, 222 ; blunders of, 235 ; aggressions of, 237, 297; resources of, 304

English Press, misleading articles in, ii. 10,112

Envoy, desirability of an Afghan, in London, ii. 139; refused to Nasrullah, 142 ; danger of foreign envoys, 245

Equality of all persons before the law, ii. 101 
Espionage system in Afghanistan, i. 259 ; ii. 202

European powers, combination of, ii. 276

Exiles in India, destiny of, ii. 180 in Russia, danger of, ii. 182

FaIzabad, i. 69 ; plot against Abdur Rahman at, 179

Faiz Mahomed Khan, story of, i. 64 ; rebellion of, 84; defeats Sarwar Khan, 84; captures Kataghan and Badakshan, 85 ; defeated and slain by Abdur Rahman, 87

Farah, victory of, i. 28

Faramurz Khan, i. 156, 189, 212; appointed governor of Herat, 216; origin of, î. 92

Farash (a household servant), ii. 87

Fard (a leaflet of paper, ancient system of accounts in Afghanistan), ii. 64

Fatteh Mahomed Khan, appointed governor of Balkh, i. 62,66 ; flies to Tashkurgan, 68; Kabul attacked by daughter of, 72

Fatteh Khan Wazir, the "King. Maker," ii. 218, 219; death of, 220 ; brothers of, 220

Fatima (Mahomed's daughter), i. 272 (note)

Festivals, ii. 108

Firdusi, quotations from, ii. 195, 271

Food (Afghan), ii. 58 (note), 94

Forbes, Archibald, quotation from his "Afghan Wars," ii. 226-234

Foreigners, reasons for employment in Afghamistan of, ii. 17; agreements with, 19; engagement of the first in Kabul, 22 ; exelusion of concessions to, 72, 209, 210

Fort at Dehdadi, ii. 69, 135, 287

"Forward Policy," commencement of the, ii. 135 ; enforcement of, $159,164,173,297$

Frari or Farari, a fugitive or exile, i. 239 (note)

French, alliance with Russia, ii. 275

Frihad, i, 66

Gandama, i. 151

Gaus-ud-Din, General, defeated by Russians at Panjdeh, i. 244
Ghafar Khan, Governor of Wakhan, ii. 145

Ghaza, a holy war for the Mahomedan faith, i. 174; ii. 51 (note)

Ghazi, a fighter for the Mahomedan faith, ii. 55

Ghazi Jan Mahomed, i. 155

Ghazni, occupied by Abdur Rahman, i. 72; Abdur Rahman's uncle set free at, 76

Ghazni Gak, Ishak defeated at, i. 268

Ghilzais, origin of name, i. 249 (note); rebellion of, 250 ; causes of rebellion, 251; outbreak, 254 ; success of, 256; final defeat, 257

Ghor, ii. 213

Ghori, storming of the fort, i. 12; arrival of Abdur Rahman at, 98

Ghulam Ahuad, i. 35, 45; dikaster to, 45, 48; laxiness of, 49 ; defeat of, 50; present in Bokhara, 57; rejoins Abdur Rahman, 60; accompanies Abdur Rahman to Balkh, 61

Ghulam Ali (Abdur Rahman's son), birth of, i. 274

Ghulam Ali Khan defeats Amir of Bokhara, i. 24, 31, 84; sent to Kabul, 97

Ghulam Haidar Charkhi, i. 212; conquers Kafirs, 290

Ghulam Haidar Orukzai, i. 8, 175, 176; kills Sarwar Khan, 177; attacks rebels at Taktapul, 185; deserted by army, 186, 267

Ghulam Haidar Tokhi, commanderin-chief, defeated by Ayub, i. 211, 212 ; defeats Ghilzais, 254 ; victory at Ata Gurh, 257 ; at Dand-i-Aba, 257; reception at Kabul, 258; appointed deputy commander-inchief, 259; commands expedition against Ishak, 267 ; defeats Ishak, 268 ; made commander-in-chief in Turkestan, 271; defeats Hazaras, 283 ; occupies Asmar, ii. 159

Ghulam Khan Durami, i. 32

Ghulam Mahomed Populzai, i. 11

Girishk, Ayub's victory at, i. 211

Gladstone, Mr, weakness of, i. 245

Goat of Bughdad, the, i. 221

Gorst, Sir John, ii. 138

Government Loans, ii. 207

Government officials, i. 209

Griffin, Sir Lepel, letter to Abdur 
Rahman, i. 190, 192; communicates with Abdur Rahman, 193; letter of conditions to Abdur Rahman, 194; proclaims Abdur Rahman Amir, 196; ii. 113 ; Abdur Rahman's appreciation of his work, 115,120

Gulbahar, arrival of Abdur Rahman at, i. 86

Haвibultah (Beloved of God), birth of, i. 146; appointed governor of Kabul, 212; excellence of, 216, 275; his chance of succession, ii. 1; position allotted to, 5 ; marriage of, 11 ; allowance of, 96 ; duties of, 99 ; receives order of G.C.M.G., 143; supremacy acknowledged, 179; qualities required in him, ii. 185,186 , 187

Hákim, a governor.

Hakim, a physician.

Halal (that which it is lawful for a Mahomedan to eat), i 140

Hamilton, Miss Lillias, i. 267 (note); ii. 70 ; accompanies Nasrullah to England, 71, 144

Hamza Mirza, i. 129

Haram (that which it is not lawinl for a Mahomedan to eat), i. 140

Harem of Abdur Rahman, ii. 97; regulation of, 110

Hashim Khan, appointed governor of Kabul by Abdur Rahman, i. 208

Hassan Shahzada, i. 170

Hazara tribe, i. 276; origin of, 277; first disturbance among, 278; answer to Abdur Rahman of, 279; defeated by Kudus Khan, 280; general rising of, 282 ; defeat of, 283

Hazdah Nahr, i. 24, 49, 64

Helmand river, i. 124

Herat, disturbances at, i. 28 ; annexation of, 210; eaptured by Kudus Khan, 215; probability of Russia's taking, ii. 286; defence of, 286 ; fortification of, 288; key to India, 290; British troops not required in case of Russia's advance upon, 299,300

Hissar, i. 137, 138; Abdur Rahman arrives at, 169 ; stratagem at, 170
Hissarak valley, i. 238

Holdich, Colonel, ii. 152

Honours and decorations in Afghanistan, ii. 109

Horses, stud of, in Kabul, ii. 73

Hotak, rebellion in, i. 225

Hotehkiss guns, stopped at Peshawur, ii. 29 ; made in Kabul, 29

Hum Hum or Hammam (a Turkish vapour bath), i. 225

Hundi (a bill of exchange), ii. 208

IBRAHTM SIRDAR, i. 62; defeated at Kabul by Abdur Rahman, 72 ; flies to Kandahar, 72

Id (Mahomedan festival), ii. 108

Ikhrajat (the daily expense office at Kabul), ii. 65

Imam, a priest, ii. 103

Impartiality required of rulers, ii. 15

Inatullah, eldest son of Habibullah, ii. 11

Independent frontier tribes, absorption of, ii. 149

India, Russian attack on, disenssed, ii. 273,274 ; intelligent opinion of, 303

Indian army, Abdur Rahman's appreciation of, ii. $\mathbf{1 3 0}$

Indo-Afghan boundary, ii. 154; settlement desired by Abdur Rahman, 157; Indian claims on, 157; Abdur Rahman's opinion on the border tribes, 158; settlement of, 161

Inn of the "Drunkards and Smokers," i. 169

Invasion of India by Russia discussed, ii. 270 ; improbability of European combination, 276 ; Asiatic combination with regard to, 277

Isa Khan defeated at Maruf, i. 256

Ishak Khan, i, 143, 175; escapes from Ghulam Haidar, 176; sent to Herat, 177; summoned to Mazar by Abdur Rahman, 188; made Viceroy of Turkestan, 206; treachery of, 235 ; origin of, 261 ; his oath of obedience, 262; hypocrisy of, 263; joins Nakhshbandi sect, 264; proclaims himself Amir, 265 ; pretended illness of, 266 ; coins rupees, 267 ; is 
defeated at Ghazni Gak, 269; his supporters now in Kabul, 295; danger of in the future, ii. 182; hatred of, 183

Ishkabad, i. 131

Islamism, Russia's policy towards, ii. 262, 263; England's policy towards, 264 ; plea for support of, 268

Ismail, see Mahomed Ismail.

Ismail, son of Ishak, ii. 184

Ivanoff, General, i. 155, 156, 236

JABAR KHAN, i. 89

Jadak Ghulam Jan, i. 89

Jahandar Shah, Abdur Rahman's letter to, i, 35 ; submits, 37

Jami, ii. 59, 195, 239, 284

Janat, story of, i. 166

Jan Mahomed "Ghazi," i. 155

Jan Mahomed Kazi, i. 168

Japan, a power to be reckoned with, ii. 277

Jan Abdul Khalik, i. 89

Jazak, i. 148

Jellalabad, arrival of Abdur Rahman at, i. 237 ; derivation of, i. 247

Jérome, M., engagement of, at Kabul, ii. 21

Jihad (a war for the Faith), preached by Abdur Rahman, i. 187

Jirga, a council of the elders of a tribe, i. 173

Joz, reception of Abdur Rahman at, i. 166

Justice, courts of, ii, 201

KaBUL, Shere Ali at, i. 62 ; captured by Abdur Rahman, 72 ; cholera at, 86

Kadriya, mystic sect of, i. 264 (note)

Kafila Bashi (the master of caravans, i. 209 (note)

Kafiristan (the country of the unbelievers), treatment of, i. 288 ; reasons of Abdur Rahman's invasion of, 288 ; a winter attack on, 289; conquered in forty days, 291; Christian missionaries on, 291; removal of inhabitants, 291; treatment of prisoners, ii. 93

Kakar, i. 53

Kala Alahdad, i. 86
Kalandar Khana, Abdur Rahman's residence, i. 143

Kalat-i-Ghilzai, fortified by Shere Ali, i. 79 ; engagement at, 81 ; victory at, 82

Kalima (the Mahomedan invoca. tion), i. 267 (note)

Kandahar, Shere Ali goes to, i. 62 ; entered by Abdur Rahman, 83 ; evacuated by English, 207; cap. tured by Ayub, 212; battle of, 215; English aggreasion towards, ii. 136 ; proposed railway to, 159

Kandahar-Ghazni-Kabul line, occupation of by English, ii. 301

Kanigurum, i. 111

Kara Khan of Nimlek, i. 92

Karakol, i. 137

Kara Kotal, i. 46

Karez, an underground water conduit or tunnel made in falling ground, for bringing water by gravitation to the surface.

Karez, Ayub's victory at, i. 211

Karez Shahzada, i. 127

Karez Wazir, i. 120

Kataghan, treachery of Mirs of, i. 17

Katal Khan, defeats Mangals, i. 239, 290

Kauffmann, General, i. 142, 155 ; ii. 253,261 ; deceitful letter of, 262

Kazi (an ecclesiastical judge), i, 208 (note); ii. 189

Kazi Hassan Ali, kindness to Abdur Rahman of, i. 128

Kazi Usgar Hazara, rebels, i. 281

Khana Abadi (the foundation of the home), a cadet battalion, ii. 105

Khanabad captured by Abdur Rahman, i. 14, 29

Khana Zad (born in the house), the offspring of slaves, ii. 93

Khana saman (or Khansaman), a household servant corresponding to a butler, ii. 87

Kharoti tribe, kindness to Abdur Rahman of, i. 106

Khawanin Mrlki (representatives of the people), ii. 189

Khazana-i - Amira (the public treasury), ii. 61

Khazana - i-Khâs (the private treasury), ii. 61

Kheil Shah Gul, i. 122, 123 
Khel-i-mulla Alim, i. 213

Khidmad, service, of. Peshkhidmad, Khidmadgar, ete.

Khilat, a present of honour.

Khirka (the mantle worn by Mahomed, now kept in a shrine in Kandahar); Amin Khan buried at the shrine, i. 63,212 (note)

Khiva, Khan of, kind welcome to Abdur Rahman of, i. 134; proposals to Abdur Rahman, 135

Khodainazar Wardak, i. 99

Khojak tunnel, construction of, ii. 135,159

Khojend, Abdur Rahman arrives at, i. 161 ; his weleome, 162

Khost, i. 14, 28, 42, 110

Khudaya Khan, i. 147, 150

Khudiya, Mahomed's wife, ii. 211

Khush Dil, i. 211, 215

Khutba, the Mahomedan sermon, i. 77 (note), 88

Khwaja, an Arabic title of respect corresponding in use to the English $\mathrm{Mr}$, but used also before the name of a holy man.

Khwaja Ahrar of Herat, ii. 45

- Am Khana, tomb of, i. 167 Ansar, tomb of, i. 48

- Baha-ud-Din, i. 264

- Changal, i. 22

Gulgun, i. 170

- Ikrar, tomb of, i. 166 - Ishak of Khatlan, legend of, i. 264 (note) Salar, ii. 153

Kilman, subjugation of, i. 247, 248

Kimberley, Lord, ii. 163

Kiran, a Persian coin, value 6d., i. 135 (note); also the name of a modern Kabul coin, value $\frac{1}{2}$ a rupee, ii. 32

Kishm, i. 29

Koh, a mountain.

Koh-i-nur (mountain of light) diamond, story of, ii, 219

Kohistan (the country of hills), i. 195

Kokand, treachery of the Russians in, i. 150

Kolab, Mir of, i. 19; disturbances in, 40,137

Komaroff, General, i. 243

Koran, the oath upon, i. 262 (note)

Kotal, a pass.

Kotal-i-Chahalzina, i. 213
Kotwal (the chief police official in a town or village), i. 209 (note)

Krupp guns at Dehdadi fort, ii. 287

Kuhandil of Kandahar, Sirdar, i. 46

Kullum in Kafiristan, fortified, i. 291 ; inscription on gate of, 292

Kunduz, the Kazi of, i. 32; Abdur Rahman arrives at, 190

Kuram, i. 9, 28, 42, 151, 258

Kurban Ali, i. 157

Kurgan Tepe, i. 170

Lagmaran valley, the devil's residence, i. 247 (note)

Lamkhan, i. 246 (note); Abdur Rahman ill at, i. 266

Landi, Afghan dried food, ii. 58

Lansdowne, Lord, advises Abdur Rahman, i. 272 ; ii. 131; arrives in India, 131 ; Abdur Rahman receives dictational letter from, 135; stops delivery of Abdur Rahman's guns, 136; appoints Roberts mission, 155 ; ultimatum to Abdur Rahman of, 156

Lataband mountain (the mountain of rags), i. 218 (note)

"Lawrence" line, ii. 298

Leglislative proposals, ii. 200

"Light of the Eyes," the, i. 97

Limekilns, ii. 69

Loyalty of the people to Abdur Rahman, i. 229

Lumsden, Sir Peter, i. 241, 243

Lyall, Sir Alfred, ii. 120; his poem, 166 ; quotation from, 240

Lytton, Lord, ii. 253, 297

MACHINERY, difficulties of transport to Kabnl, ii. 37

M'Dermott, Mr, mint master at Kabul, ii. 32

Maclean, General, interviews Ayub, i. 260

Macmahon, Captain, ii. 160

Mahomed the prophet, teaching of, ii. 167 ; government of, 188 ; honesty of, 211

Mahomed Akbar Khan, i. 89

- Alam Khan, i. 1; ii. 19; brave death of, 31

_Ali (son of Shere Ali), i. 42; death of, 63

- Ali Khan, sent against Kafirs i. 290 
Mahomed Amin Khan, i. 2; death of, 63 ; welcomes Abdur Rahman, 70 Azim Khan, i. 10, 42; flight to India, 43; appointed Amir, 88; turns against $\mathbf{A}$ bdur Rahman, 90 ; variances with Abdur Rahman, 95 ; leaves Kabul, 97 ; advances to Ghazni, 99 280 - Aziz, i. 76

- Hussain Khan Hazara, i. 269, 278 ; reward of, 281 ; rebels, 281 ; captured, 283

- Ismail, i. 90, 91, 95; treachery of, 96,97 ; enters Kabul and proclaims Shere Ali Amir, 98

Khan, i. 57; governor of Kandahar, ii. 136

Omar, birth of, i. 201; his chance of succession, ii. 1 Sadik Khan, i. 254

Shah Khan, danghter of, married to Habibullah, ii. 11 Yakub, i. 95

Yamen Khan, i. 14; cowardice of, 16

Ynsuf Khan, i. 201

Zaman Khan, i. 35

Mahomedan philosophy, i. 230 (note)

Mahmud of Kunar, i. 233; defeat of, 234

Maimana, flight of Mirs to, i. 93; siege of, 95 ; surrender of, 96 ; Dilawar Khan defeated at, 240

Maiwa or Mewa, fruit.

Maiwand, defeat of the British at, i. 196

Majnun, story of the lover, ii. 82

Makur, i. 78

Malik (the headman of a town or village), ii. 188

Mangal, i. 238

Mango Khel, i. 238

Manners Smith, Captain, ii. 160

Manufactures started at Kabul, ii. 26; miscellaneous, 47

Marriages, Habibullah's political, ii. 11

Mashhad, i. 128, 129, 216

Mazar-i-Sherif, i. 47; arrival of Abdur Rahman at, 91; fort near, 272 ; origin of name, 272 (note); residence of Abdur Rahman, 272; narrow escape of Abdur Rahman at, 273
Mazindran, ii. 277

Members of Parliament, ignorance of, ii. 250

Merv, annexed by Russia, ii. 123, 287

Middleton, Mr, superintendent of cartridge factory at Kabul, ii. 32 , 72

Military and civil departments at Kabul, ii. 51

Military bands in Kabul, ii. 48

Minerals in Afghanistan, ii. 72, 169

Mint at Kabul, ii. 31

Mir Akbar Khan, i. 89

- Akhor, master of the horse, ii. 88

Alam Khan, i. 122, 125, 126

Ali Wali, i. 19

Ata Khan of Herat, i. 281

Atalik of Kataghan, appeals

to Bokhara, i. 9 ; defeated by

Abdur Rahman, 12; flies to

Badakshan, 14; stirs up re-

bellion, 31 ; plots against Shere

Ali, 44

Axiz, i. 29

Baba Beg, i. 21, 29, 148; plots against Abdur Rahman, 178; punishment of, 181; makes friends with Omar, 183; joins Abdur Rahman with his army, 187; renewed treachery, 189

Hákim Khan, i. 93

Jahandar Shah, i. 29, 34; insults Abdur Rahman, 35, 36; submits, 37 ; defeated by Faiz Khan, 85 ; offers daughter to Abdur Rahinan, 98; sons of, 162 Munshi, ii. 18; hides behind the curtain, 160

Mnzaffar, King of Bokhara, see Bokhara

- Omar, i. 178, 182, 187, 189

- Shah, i. 19; incapacity of, 28

Sora Beg, i. 15, 137, 293

Sultan Murad, i. 21, 69, 175; defeated, 183; joins Abdur Rahman, 187; disloyalty of, 271 ; flight of, 273 ; ii. 112

Yusif Ali, i. 16; rebellion of, 19, 25; murder of, 29

-Yusif Ali of Shignan, rebellion of, i. 235

Mistri (an artisan), i. 259 (note)

Muezzin, the Mahomedan call to prayer, ii. 205 
Mufti (an ecclesiastical head of churches), ii. 189

Muhagir, ii. 188

Mulk, the people.

Mulki (the civil department of government at Kabul), ii. 51, 61

Mullah (a Mahomedan priest), ii. 188

Mullah Adikulla, Abdur Rahman marries daughter of, i. 201

Murghab, i. 257; affair with Russians at, 287

Murder, punishment for, ii. 66 ; in Najrab, i. 224

Mushk Alim, i. 251, 253 (note)

Musicians at court, ii. 88

Muslims, wickedness of, i. 138 ; loyalty to England of, ii. 269

Mutahsib (a religious protector), ii. 205

Mystic sects of Mahomedans, i. 264

NADIR SHaH, ii. 215

Naib-ul-hukuma (the deputy of the sovereign), i. 208 (note)

Nakhshband sect, i. 264

Najrab, murders in, i. 224

Namazgah, i. 10

Narin, battle at, i. 31

Nasrullah, birth of, i. 146; chanee of succession, ii. 1; subordinate to Habibullah, 6; wives of, 13 ; story of his wife's dress, 24; allowance of, 96 ; duties of, 102 ; visit to England, 142; account of his journey, 144

Native princes of India, Abdur Rahman's contempt of, ii. 132, 170

Nauroz (new year's festival), ii. 108

Nawa Arghastan, i. 79

Nazar Wardak, i. 72

Nazami (the military department of government), ii. 52

Nazim-ud-din, i. 157

Nazir, Lord of the Seal, ii. 87

Nazir Haidar Klan, i. 49, 84, 98 ; defeated at Zanakhan, 102, 103

- Khan, i. 49; returns to save his brother, $50 ; 65,68,74$

Mahomed Sarwar, brings letter from English to Abdur Rahman, i. 190

Negotiations between Abdur Rahman and British, i. 193

Neh, i. 126
"Neutral Territory," the game of, ii. 147

Newspaper cuttings concerning Afghanistan, ii. 186, 187

Nimlek, battle of, i. 67 ; capture of, 91,92

Nur Mahomed Shinwari, i. 237

Nushki, arrival of Abdur Rahman at, i. 120

OATHs upon the Koran, i. 262 (note)

O'Meara, Mr, dentist at Kabul, engagement of, ii. 25

Omra Khan of Bajaur, i. 282; now at Kabul, 294; ii. 159

Oxus, arrival of Abdur Rahman at, i. 50; fighting on the, 52; crossed by Abdur Rahman, 137

PACK, Mr, opens hospital in Kabul, ii. 71

Page boys of Abdur Rahman, ii. 91, 105

Paghman, Kafirs removed to, i. 291

Palaces of Abdur Rahman, ii. 104

Palalik, i. 122, 124

Pamirs, occupation by Russians, ii. 129,153 ; boundary fixed, 154; possible line of attack on India, 287

Panjdeh, Russian attack at, i. 242 ; its lesson, 246 ; ii. 151 ; annexed by Russia, ii. 123

Panjshir valley, i. 86, 193 (note); ii. 288

Parwana Khan, i. 157, 212; devotion to the Amir, 216, 259; origin of, ii. 92

Payandah Khan (father of Fatteh Khan), ii. 220

Peiwar Kotal, i. 151

Persia, Russian ascendancy over, ii. 131, 269

Perso-Afghan frontier, ii. 150

Personal attendants of Abdur Rahman, ii. 87

Peshawur-Kabul road, insecurity of, i. 236; Abdur Rahman's new road, ii. 68

Peshkhidmats, a personal household servant, ii. 87, see Khidmat

Petitions, mode of, ii. 103

Photography, objection to, i. 142; fear of, ii. 27 
Pilgrimages, insanitary conditions of, ii. 206

Pishin, arrival of Abdur Rahman at, i. 120, 151

Post-office, ii. 78

Prince of Wales, ii. 140

Protectionist ideas of Abdur Rahman, ii. $41,42,72,75,208$

Public offices at Kabul, ii. 65

Public works, ii. 68

Pul-i-Khishti, fight at, i. 243

Pulsirat (the pass leading to Paradise) i. 166

Pumbah Faroshi, i. 163

Pusht-i-Rod, i. 80, 95

Pyne, Sir Salter, engagement of, ii. 23 ; carries letter to the Viceroy, 157

RAFIK-I-DIN, i. $43,45,71,72,73$, 74

Rahdari (a passport), i. 200 (note); ii. 65

Railways, Abdur Rahman's objection to, ii. 60, 77, 208, 209

Rauf Abdul Khan, appointed commander-in-chief, i. 6

Rawal Pindi, reasons of Abdur Rahman's visit to, i. 242 ; ii. 27 ; meeting of Lord Dufferin at, 128

Recruiting system, ii. 53 ; conscription to be avoided, 194

Refugees at the court of Abdur Rahman, i. 293, 294

Regel, Dr Laberd, Russian explorer, i. 235

Religion, necessity of, ii. 204 ; establishment of, 205

Religious convictions of Abdur Rahman, i. 171, 172

Religious toleration, ii. 103

Religious faith of Afghans, ii. 172

Representative of Afghanistan in London, desired by Abdur Rahman, ii. 139; refused to Nasrullah, 142; advantages of, 244 ; dangers of, $245 ; 247,251,256$

Representative government in Afghanistan, ii. 188, 189

Responsibility of a ruler, i. 221

Revenue, sources of, ii. 62

Riches, Mr, ii. 76

Ridgway, Sir West, ii. 152, 240

Rifle manufactory at Kabul, ii. 33

Ring, story of the, ii. 204
Ripon, Lord, ii. 116, 120

Roads in Afghanistan, ii. 68

Roberts, Lord, i. 152; defeats Ayub, 198 , refusal of mission of, 282 ; ii. 155 ; commences "Forward Policy," ii. 135; mission forced on Abdur Rahman, 138; leaves India, 138; dislike of Abdur Rahman for, 156, 157

Roshan, i. 235,236 ; ii. 145,153

Roza, i, 99

Roznameha (the department of the daily income and expenditure), i. 209 ; ii. 65

Rubab (a musical instrument), ii. 106

Runjit Singh, ii. 219

Russians, receive Abdur Rahman, i. 139; communications with Afghanistan, 145; assault Shahr Sabz, 147; breach of faith, 147 ; attempt to win over Abdur Rahman, 148, 149 ; capture Kokand, 150 ; seduce Shere Ali, 150; promises to Shere Ali, 151; receive Shere Ali's embassy, 153; claim Shignan and Roshan, 236; Afghan boundary commission, 241; Panjdeh incident, 243; aggression on the Pamirs, 285; excuse of a, 286; advance at Mnrghab, 286; interference in Kafiristan, 289 ; incident of the gun of Herat, ii. 54; mischief-making, 122; steady aggression of, 123; desire a distracted Afghanistan, 182; policy in Central Asia, 260; successful deceptions of, 262; danger to, in attacking Afghanistan, 268; duplicity of, 270 ; invasion of India discussed, 270,271 ; ignorance of Indian loyalty, 272; avarice of, 274 ; political skill of, 284 ; danger to, in attacking Herat, 286; probable line of attack on Herat, 287 ; checkmated, 288 ; anticipations of Abdur Rahman's death, 289; aggression of, 291 ; advantages of their nonexclusiveness, 295; alliance with Afghanistan impossible, 296 ; difficulties in the way of their advance, 299, 300

Russo-Afghan boundary commission, i. 241 ; ii. 151, 152; gratitude of Abdur Rahman for, 153 
SADI, quotations from, ii. 16, 28, 51, $106,111,160,190,195,197,202$, $241,243,251,291$

Sadn of the Sala Khel, i. 237

Safar Khan, ii. 87

Safaraz Khan, i. 89

Safaraz Ghilzai, i. 99

Saidabad, fight at, i. 74; second battle at, 76

Said-ud-Din, i. 283

Saif-nd-Din, incapacity of, i. 239

Sakukat, stamp office, ii. 65

Salisbury, Lord, appealed to by Abdur Rahman, ii. 138, 155

Samarkand, Abdux Rahman arrives at, i. 143; stay at, 144, et sequ; leaves, 157,159

Sandeman, Sir Robert, i. 234

Sangkhurd (stone-eater), i. 283

Sarakhs, annexed by Russia, ii. 123

Sar-i-chasma, i. 99

Sar Roza, i. 104, 105

Saripul, rebellion at, i. 65 ; Mir of, 93

Sarwar Khan, i. 43, 76, 84; defested, 85,116 ; intrigues agrinst $A$ bdur Rahmmn, 154; sent to Turkestan, 175 ; killed, 176

Seaport required, ii. 212

Seistan, Abdur Rahman enters, i. 124

Shah of Persia welcomes Abdur Rahman, i. 130; invites Abdur Rahman to Tehran, 130

Shah Abdin defeated by Abdur Rahman, i. 67

Gul Baluchi, i. 122, 123, 124

"__Jehan Padshah," i. 116, 117

Khan, General, defeats

Russians, i. 287

- Khan Hotak, leader of

Ghilzai rebellion, i. 256

Mahmud, ii. 217, 218, 219

Narwaz Khan, i. 76

Shujah, ii. 218,297

Zaman, ii. 217

Shahid (one who gives his life for the faith), ii. 55, 172

Shahmad, governor of Jellalabad, i. 237

Shahr-i-Sabz, i. 146, 147, 166, 167

Shahzada Hassan, i. 170; letter from Abdur Rahman to, 174

Shaikh Ali tribe of Hazaras, i. 278 - Mir, i. 45, 71
Shain Khan, i. 72

Shair Gul, i. 89

Shams-ud-Din Khan,i. 22; cowardice of, 23

Sharif Khan, i. 62, 96, 122, 125

Shashgao, stratagemat, i.74;skirmish at, 100

Shatir (grooms), ii. 87

Sheep introduced into Afghanistan from Australia, ii. 74

Sher Afzul, intrigues against Shere Ali, i. 43,44 ; starts for Bajgarh, 45 ; submits to Shere Ali, 46; imprisoned by Shere Ali, 48 ; joins Abdur Rahman, 76; declared Amir at Kabul, 77 ; takes cholera, 86 ; dies, 88

Sher Surkh Baba, council at, ii. 216

Shere Ali Khan, proclaimed Amir, i. 42 ; family feuds of, 43 ; breaks his oath to Azim, 43; invades Turkestan, 44; wars against his brothers, 62; kills Amin Khan, 63 ; madness of, 63 ; misrule of, 71 ; defeated at Saidabad, 74, 76; flies to Kandahar, 76; deposed, 77 ; advances against Âbdur Rahman, 79 ; forces of, at Khalati-Ghilzai, 80; defeated by Abdur Rahman, 82; flies to Herat, 83; joins Faiz Mahomed in Balkh, 86 ; advances on Kabul, 86 ; defeated at Gulbahar, 86; flies to Balkh, 87 ; sells Balkh to the Mirs, 91 ; captures Kandahar, 97; proclaimed Amir, 98 ; advances against Abdur Rahman, 100; defeats Abdur Rahman at Zanakhan, 102; turns against English, 149 ; agreement with Russians, 151; defeated by English, 151; death of, 152; embassy to Russia, 153 ; promises to Russians, 154 ; mistake in his successor, ii. 8; rudeness to Queen Victoria, 235

Shere Ali Kandahari, i. 154 ; betrays Abdur Rahman to Russians, 155 ; removed by English to Karachi, 207 ; sons now at Kabul, 294

Shere Khan the imposter, i. 234

Shere Mahomed Khan, i. 280

Shibarghan, death of Sarwar Khan at, i. 176

Shignan, i. 235 ; ii. 145,153

Shinwaris, lawlessness of, i. 237 ; defeated by Abdur Rahman, 238 
Shir Mahomed Khan, i. 4

Shirabad, Mir of, welcomes Abdur Rahman, i. 53, 65

Shulukto, i. 99

Sikandar Charkhi, i. 50, 57 ; remains in Bokhara, 61, 76

- Khan, i. 255, 256

- Orukzai, i. 50

Sirhand Sikandar Khan, i. 255

Sivards, the, i. 120

Slaves, position of, ii. 92

States, Small, absorption by great Powers of, ii. 146, 147

Snake story, i. 284

Sohrab, Colonel, i. 45, 49, 50, 90, 96

Somatash, i. 285 ; ii. 259

Spies in Afghanistan, i. 259 (note)

Stán, affix meaning country or home.

"Star of Saints," the, i. 70

Stewart, Sir Donald, i. 198; ii. 120, 134

Stewart, Mr, superintendent of engine shops at Kabul, ii. 35

St John, Sir Oliver, i. 253

St Petersburg, Abdur Rahman invited to, i. 141

Subsidy from the Indian government, ii. 63, 114, 256

Successor of Abdur Rahman, ii. 1; reasons for not declaring, 2; elaims through the mother, 7,8

Suddozai, fate of, ii. 180 ; origin of, 215

Sufi Abdul Hak, ii. 26

Sufi Khan, i. 89

Suhar Wardi, mystic sect of, i. 264 (note)

Sukila, i. 12

Sultan of Turkey, influence on Amir of, ii. 267

Sultan Ahmad Khan, i. 28

- Ali, i. 46

- Baba, i. 276

- Jan, Governor of Herat, i. 76

- Mahomed Khan, Mir Munshi, see Mir Munshi

- Mahomed Khan, intrigues against Dost Mahomed, i. 42

Murad of Kataghan, see Mir Sultan Murad

Sunis and Shiahs, i. 276 (note)

Syad (Sayad, Said or Saiad), the descendants of Mahomed's daughter Fatima and her husband Ali, i. 113, 252 (note)
Syad Mahmud of Kunar, rebellion of, i. 233; defeated by Abdur Rahman, 234

TAGAO, i. 71

Tahwilat, (revenue office), ii. 65

Tailoring Department in Kabul, ii. 43

Takbir (the magnification of Allah Akbar), i. 58 (note)

Takht-i-rawan (a sedan chair carried between two horses or mules), i. 85

Taktapul, i. 2, 25, 28, 91, 96; fort at, 185

Talikhan, attack on, i. 19, 22

Tamuryan, i. 213

Tang-i-karun, road to Peshawar via, ii. 68

Tanga, a coin of Bokbara, value 4d., i. 39 (note), 54, 97, 98; also the name given to a modern Kabul coin, value $\frac{1}{3}$ rupee; ii. 32

Tannery established at Kabul, ii. 38

Tapa (Afghan), Tepe (Turkoman), a hill.

Tarakhel, Abdur Rahman arrives at, i. 71

Tarakki tribe, i. 255, 256

Tarikh-i-Rasidi, i. 235 (note)

Tashkend, Governor of, i. 148; fails to invade Afghanistan, 149; Abdur Rahman taken prisoner to, 158; Abdur Rahman settles in, 159

Tashkurgan, Abdur Rabman appointed governor of, i. 2; visit to, 25, 48; arrival of Abdur Rahman at, 91

Tasker, $\mathrm{Mr}$, superintendent of Tanneries, ii. 39

Taxi (the name given to a Persian greyhound), i. 225

Thalla, i. 81

Thornton, Mr, superintendent of dye factory, ii. 40

Timur, ii. 4

Timur Mirza Shah, ii. 158, 217

- Shah Ghilzai, execution of, i. 258

Titles of Abdur Rahman, ii. 256

Tolad Khan, story of the impostor, i. 150

Trade in Afghanistan, ii. 76

Transport, preparations for military, ii. 194 
Travellers, safety of, ii. 69; Afghanistan a paradise for, 209; futile writings of, 279

Treasury at Kabul, ii. 61 ; state of, 193

Triple Alliance of Mahomedan States, ii. 266

Tughlak, ii. 213

Turbat-Isa-Khan, i. 127

Turkoman guides, i. 132; quarrels with Persians, 132

Tutam Darah, i. 70

\section{UNCHI, i 75}

Uratepe, i. 164

Urgunj, i. 130, 134

Uruzghan, occupied by Afghans, i. 280

Usbegs, attack of, i. 52

VACCINATION introduced into Afghanistan, ii. 71

Victoria, Her Majesty Queen, ii. 9,130 ; toast proposed by Abdur Rahman, 131; desire of Abdur Rahman to visit, 140; thanks of Abdur Rahman to, 143; favours of, 248

Victoria, Lake, ii. 153

Visit of Abdur Rahman to India, impressions during, ii. 130, 132, 133

WakHan, ii. 145 ; left to the English, 288

Wali Mahomed, Colonel, i. 45; courage of, 65

Wali Mahomed, Governor of Akcha, treachery of, i. 64,66

Wana, i. 111 ; ii. 158

Wardaks, slaughter of the, i. 75

Warning of Abdur Rahman to the British Government, ii. 180
Waziristan, Abdur Rahman enters, i. 108; kindness of inhabitants 108

White, Sir George, ii. 138

Wives of Abdur Rahman, ii. 97

Women, position of, in Mahomedan estimation, i. 272 (note); under the old Afghan law, ii. 66; under new laws, 67; dowry of, 67 ; seclusion of, 109; education of, 198

YaGHistan (the country of the unruly), ii. 157

Yakobagh, i. 168

Yakub Khan made Governor of Herat, i. 42; proclaimed Amir, 151 ; promises to the Russians, 153,175 ; followers now at Kabul, 294

Yanoff, Colonel, insolence of, i. 285; ii. 154

Yar Mahomed Khan, Governor of Herat, i. 4

Yartepe, i. 161; Abdur Rahman arrives at, 168

Yate, Colonel, ii. 152, 153

Younghusband, Captain, i. 285

Yrunani (the Greek medical system), ii. 70

ZAI, affix meaning the son of, $c f$. Suddozai, Orakzai, etc.

Zabardast Khan, i. 240

Zanakhan, defeat of Abdur Rahman at, i. 102,103

Zelenai, General, ii. 151

Zhob, Abdur Rahman arrives at, i. 112,113 ; Wana Zhob, ii. 158

Zimma, Sir Lepel Griffin at, i. 196

Zulfikar (the name of Ali's sword), ii. 153

Zurmat, arrival of Abdur Rahman at, i. 104 




